\title{
EM SE PLANTANDO, CIDADE DÁ O AGRONEGÓCIO E A REPRODUÇÃO DO URBANO NA REGIÃO DE RIBEIRÃO PRETO
}





\section{EM SE PLANTANDO, CIDADE DÁ O AGRONEGÓCIO E A REPRODUÇÃO DO URBANO NA REGIÃO DE RIBEIRÃO PRETO}




\section{AUTORIZO A REPRODUÇÃO TOTAL OU PARCIAL DESTE TRABALHO, POR QUALQUER MEIO CONVENCIONAL OU ELETROONICO, PARA FINS DE ESTUDO E PESQUISA, DESDE QUE CITADA A FONTE.}

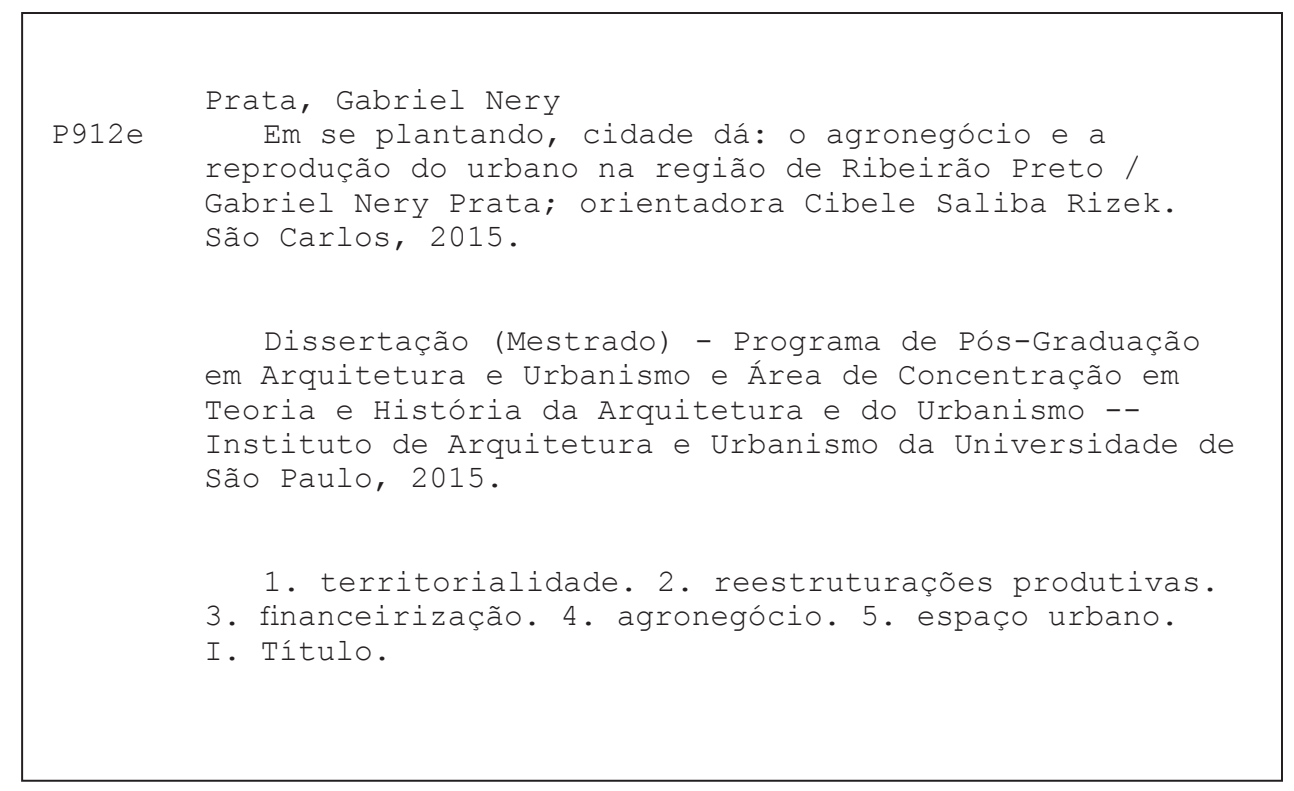




\section{EM SE PLANTANDO, CIDADE DÁ O AGRONEGÓCIO E A REPRODUÇÃO DO URBANO NA REGIÃO DE RIBEIRÃO PRETO}

Dissertação apresentada ao Instituto de Arquitetura e Urbanismo de São Carlos da Universidade de São Paulo, na área de concentração Teoria e História da Arquitetura e do Urbanismo.

Orientadora Profa. Dra. Cibele Saliba Rizek 



\section{FOLHA DE JULGAMENTO}

Candidato: Arquiteto e Urbanista Gabriel Nery Prata

Título da Dissertação: "Em se plantando cidade dá: o agronegócio e a reprodução do urbano na região de Ribeirão Preto".

Data da defesa: $28 / 04 / 2015$

\section{Comissão Julgadora:}

Profa. Assoc. Cibele Saliba Rizek (Orientadora)

(Instituto de Arquitetura e Urbanismo - IAU/USP)

Profa. Dra. Lúcia Zanin Shimbo

(Instituto de Arquitetura e Urbanismo - IAU/USP)

Prof. Dr. Danilo Volochko

(Universidade Federal do Paraná - UFPR)

\section{Resultado:}
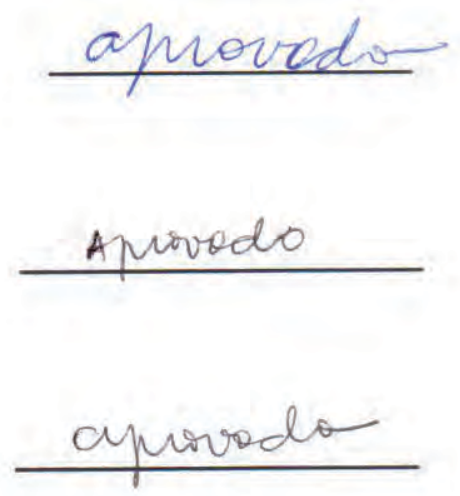

Coordenador e Presidente da Comissão de Pós-Graduação do Programa de Pós-Graduação em Arquitetura e Urbanismo: Prof. Dr. Márcio Minto Fabrício 
apresentação 
Este trabalho busca analisar a relação entre o agronegócio e a produção e reprodução do espaço urbano, tendo como foco a região de Ribeirão Preto - SP, dada sua importância econômica na produção agrícola sucroalcooleira nacional, apontando os processos de mecanização, industrialização e reestruturações produtivas no território regional, por meio da implantação de complexos agroindustriais, a partir dos anos 1970, sendo abordadas as noções de região e território, para caracterização do objeto de pesquisa, e destacada a atuação direta do Estado na produção sucroalcooleira e na expansão urbana nacional. Serão apontadas as alterações produtivas no contexto neoliberal a partir dos anos 1980, assim como o papel do setor privado e os processos de fusão, aquisição e transnacionalização no setor sucroalcooleiro. A relação cidade-campo será discutida, considerando a produção agrícola enquanto esfera produtiva de grande relevância para o desenvolvimento das cidades da região, apontando os conflitos do agronegócio e seus desdobramentos no âmbito urbano. A abordagem da expansão do mercado financeiro à produção agrícola de commodities e ao mercado imobiliário, por fim, aproximará o agronegócio e a reprodução do urbano, culminando na questão da terra enquanto denominador comum entre mercados financeirizados.

Palavras-chave: agronegócio, reprodução do espaço urbano, financeirização, reestruturações produtivas, territorialidade. 
abstract 
This research analyzes the relation between agrobusiness and the production and reproduction of the urban space, focusing on the region of Ribeirão Preto - SP, because of its economic importance in the national sugarcane farming, pointing the mechanization, industrialization and productive reestructuring processes on the regional territory, through the implemention of agroindustrial complex, from 1970, addressed the concepts of territory and region, to caracterize the object of research, and highlighted the direct involvement of the State in sugarcane production and national urban sprawl. Productive changes on the neoliberal context from the 1980s will be identified, as well as the role of the private sector and mergers, acquisitions and transnacionalizations processes in the sugarcane sector. The town-country relation will be discussed, considering the agricultural production as great relevance productive sphere for the development of cities in the region, pointing the agrobusiness conflicts and its developments in the urban context. The approach of expansion of financial market to agricultural commodity production and the housing market finally zoom into agrobusiness and urban reproduction, culminating in the land issue as a common denominator among financialized markets.

Keywords: agrobusiness, reproduction of urban space, financialization, productive reestructuring, territoriality. 

A meus pais, ao que se foi e aos que ainda tenho... 
agradecimentos 
Agradeço à minha orientadora, Prof. ${ }^{a}$ Dra. Cibele Saliba Rizek, por todo o apoio, dedicação, comprometimento e cuidado que teve desde os primeiros passos - desde o início da graduação, ensinandome a ver o mundo através de outros pontos de vista - até a conclusão deste trabalho, lendo atenciosamente até a última palavra. Pelas reuniões e ajudas, pela compreensão em meus momentos de dificuldade, pela paciência gigantesca, pelo incentivo constante e pela enorme colaboração para tornar este trabalho realidade.

Aos professores, técnicos e funcionários do Instituto de Arquitetura e Urbanismo de São Carlos, por terem me guiado e auxiliado durante todo o processo de graduação e pós-graduação.

Ao Laboratório de Estudos do Ambiente Urbano Contemporâneo - LEAUC - e ao Núcleo de Apoio à Pesquisa - NAPUrb -, pelas discussões teóricas e pontos relevantes, que contribuíram para as discussões presentes neste trabalho.

Aos membros da banca, Prof. ${ }^{a}$ Dra. Lucia Shimbo e Prof. Dr. Danilo Volochko, por avaliarem e contribuírem para a realização desta pesquisa.

Aos companheiros de pós-graduação e dos grupos de pesquisa de que participei, pelo apoio, pelos conselhos e pelas experiên- 
cias compartilhadas.

Aos grandes amigos são-carlenses, em especial à Natália Costa, amiga e companheira da pós; ao Rafael Pim, ao Fagner Miguel da Silva e à Juliana Adorna, pela companhia agradável, pelas risadas e pelo ombro amigo.

Aos grandes amigos sanjoanenses de longa data, Renata Bacelar, Victor Wanschel e Danieli Balarini, pela compreensão de minhas constantes ausências durante o mestrado e pela amizade que temos cultivado durante a última década.

Ao Bruno Andrade, pela disposição em revisar este trabalho, pelo apoio emocional e por sempre estar ao meu lado, até nos momentos mais difíceis durante o mestrado.

Aos meus pais, José Nery Prata (in memorian), Nilce Helena Francisco Gomes Peretti e Antonio Gomes Peretti, meus irmãos Guilherme Prata e Silvana Maineri, pelo apoio, pelo carinho e compreensão ao longo da vida e, principalmente, pela enorme paciência que tiveram comigo durante o mestrado.

À CAPES, pelo apoio financeiro.

$\mathrm{E}$ a todos os que colaboraram de maneira direta ou indireta, por meio de palavras, sorrisos, gestos de carinho e amizade, apoio e compreensão. Longe ou perto, todos foram importantíssimos na conclusão deste trabalho.

Deixo aqui meu enorme sentimento de gratidão a todos. 

sumário 


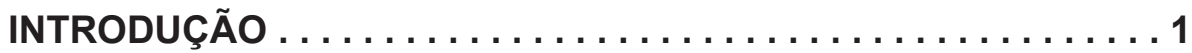

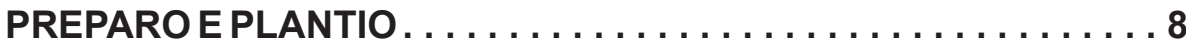

Aconstrução do território . . . . . . . . . . . . . . . . . . . 11

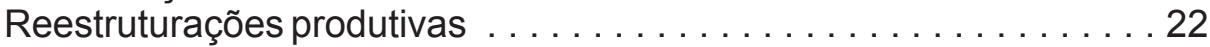

CORTE E COLHEITA . ........................ 38

Especificidades na região de Ribeirão Preto . . . . . . . . . . . . 41

ARegião metropolizada. . . . . . . . . . . . . . . . . . . 66

BENEFICIAMENTO E BOLSA . . . . . . . . . . . . . . . 76

Reestruturações neoliberais . . . . . . . . . . . . . . . . . . . . .79

Os conflitos nas relações de trabalho. . . . . . . . . . . . . . . . 86

Os conflitos na distribuição de terras, fusões e transnacionalizações. . 96

Os conflitos na produção alimentar . . . . . . . . . . . . . . . . . . 102

MERCADORIAE MERCADO . . . . . . . . . . . . . . . . 108

Dinâmicas entre mercados ......................... 111

Commodities agrícolas e mercadorias urbanas . . . . . . . . . . 116

Aterra como denominador comum .................... 148

BALANÇO E CONCLUSÕES. . ................... 156

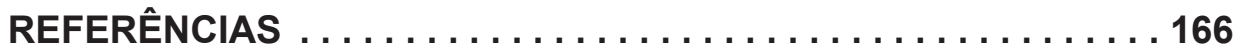


índice de figuras 


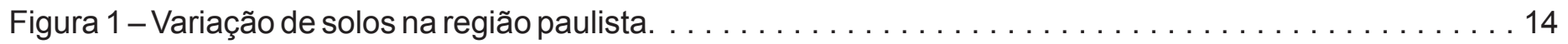

Figura 2-Rendimentos do café no estado de São Paulo, de $1912-1918 \ldots \ldots \ldots \ldots \ldots \ldots \ldots \ldots 18$

Figura 4 - Localização dos Imigrantes que passaram pela Hospedaria de Imigrantes

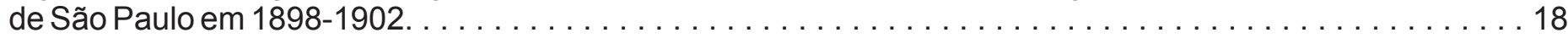

Figura 3 - Rendimentos do café no estado de São Paulo, de 1926-27 a 1930-31 . . . . . . . . . . . . . 19

Figura 5 - Localização dos Imigrantes que passaram pela Hospedaria de Imigrantes

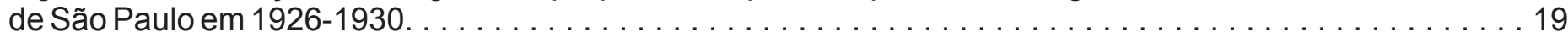

Figura 6 - Cultura do café e vias férreas às vésperas da crise de $1929 \ldots \ldots \ldots \ldots \ldots \ldots \ldots \ldots \ldots \ldots \ldots \ldots$

Figura 7 -As tradicionais áreas canavieiras do estado de São Paulo - Brasil (1950-2010). . . . . . . . . . . 32

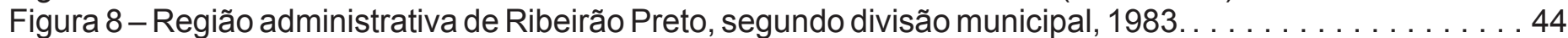

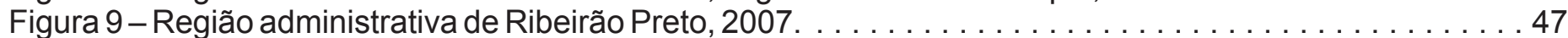

Figura 10 - Localização de usinas de cana-de-açúcar na Região Administrativa de Ribeirão Preto-2010. . . 56

Figura 11 - Usinas de Cana-de-Açúcar e Destilarias no estado de São Paulo-2008 . . . . . . . . . . . . . . . 60

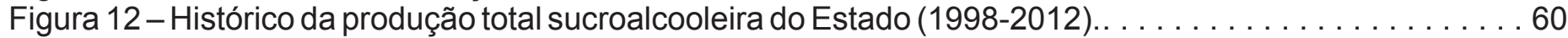

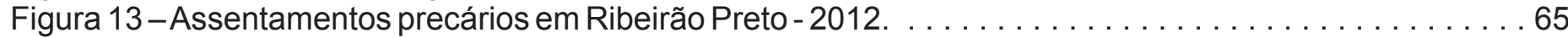

Figura $14-$ Região de influência regional e nacional de Ribeirão Preto. $\ldots \ldots \ldots \ldots \ldots \ldots \ldots \ldots \ldots$

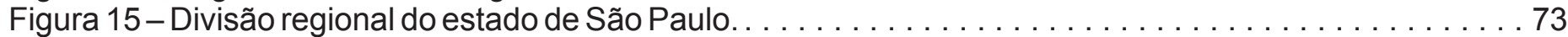

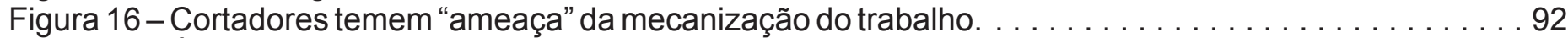

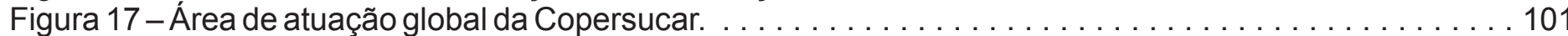

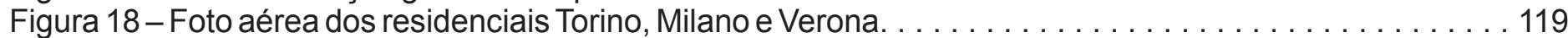

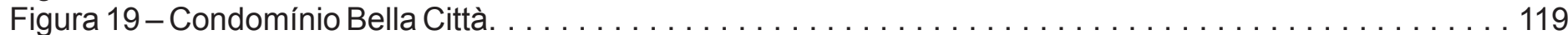

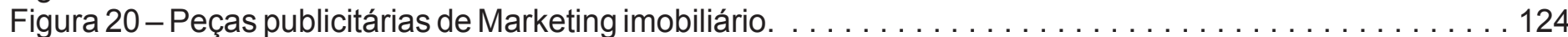

Figura 21 - Diagrama de evolução da malha urbana de Ribeirão Preto de 1900 a 2013 . . . . . . . . . . . . . . 133

Figura 22 - Localização dos empreendimentos do Minha Casa Minha Vida em Ribeirão Preto - 2012 . . . . . . . 134

Figura 23 - Diagrama de evolução da malha urbana de Sertãozinho de 1950 a 2005 . . . . . . . . . . . . . . . . . 138

Figura 24 - Localização da área do loteamento Jardim Nova Europa.. . . . . . . . . . . . . . . . . . . . . . . . . . . . . 141

Figura 25 - Mapa de distribuição e variação dos preços dos lotes

do empreendimento Jardim Nova Europa - Sertãozinho, SP. . . . . . . . . . . . . . . . . . . . . . . . . . . . 142 
índice de tabelas

índice de gráficos 
Tabela 1 - Exportação anual de açúcar por estado brasileiro (toneladas) -2010/2011-2014/2015 . . . . . . . 43

Tabela 2 - Exportação anual de etanol por estado brasileiro (mil litros) - 2010/2011-2014/2015 . . . . . . . . 43

Tabela 3 - Produto Interno Bruto e distribuição do Valor Adicionado, por setor de atividade. . . . . . . . . . . . 51

Tabela 4 - Taxas de crescimento populacional por situação de domicílio. Regiões de governo 1970-1991. . . 55

Tabela 5 - Área plantada com cana-de-açúcar (ha) no Brasil, 1980-2011 . . . . . . . . . . . . . . . . 87

Tabela 6 - Histórico da produção total sucroalcooleira do Estado (1998-2012) . . . . . . . . . . . . . . . 88

Tabela 7 - Características dos estabelecimentos agropecuários,

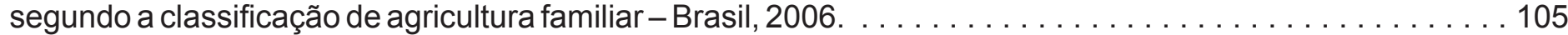

Tabela 8 - Relação de parcelamentos aprovados em Ribeirão Preto, 1970 a 2011 . . . . . . . . . . . . . . 130

Tabela 9-Produção de álcool por usinas na região administrativa de Ribeirão Preto, em 2012 . . . . . . . . . . 149

Gráfico 1 - Evolução da população por local de residência - Brasil (1950-2010). . . . . . . . . . . . . . . . 25

Gráfico 2 - Distribuição do Produto Interno Bruto por município - Região Administrativa de Ribeirão Preto. . . . 49

Gráfico 3 - Distribuição da área total dos imóveis rurais (1) por categoria - Brasil e grandes regiões (2009). . . 105 
introdução 
Em um prédio na principal rua de comércio de Sertãozinho, cidade localizada no interior do estado de São Paulo, ocorria uma reunião a portas fechadas. A sala tentava reproduzir um ambiente amigável e descontraído, como todo projeto de ambiente corporativo tenta fazer quando se trata de ambientes de negociação. Sentados em poltronas confortáveis, figurões tomavam café e conversavam, em meio a vários papéis espalhados pela mesa.

Em uma ponta estava o cliente: um fazendeiro com anos de experiência em produção de açúcar na região e de fala simples, com aquele sotaque típico do interior paulista, puxando o "erre". Ao seu lado um rapaz mais jovem, dotado da ousadia que faltava ao primeiro, mais concentrado e menos bonachão. Bastante articulado, defendia os interesses do cliente, principalmente quando a conversa entrava em zonas numéricas, com porcentagens e termos específicos, sempre atento às cifras e números que surgiam entre os papéis e falas provenientes dos outros na sala.

Na outra ponta, um senhor de aparência bastante abastada e com um falar não tão caipira, capaz de reproduzir um sotaque bastante próximo do paulistano. Mantinha uma postura que demonstrava inte- 
resse e segurança, buscando ser convincente na ideia que queria vender, típico de todo empresário interessado em comercializar seu peixe. Seus olhos brilhavam com os valores das cifras ditas entre uma piada e outra, entre um gole de café e uma explanação, principalmente com as que ficavam na casa das dezenas, centenas de bilhões. Ao seu lado, o gerente, com uma calculadora a tira colo, bastante frio e calado, sempre questionando os valores, principalmente os provenientes da outra ponta da mesa.

Espalhados pelos cantos da grande mesa retangular, outros profissionais exibiam as qualidades e benefícios do produto ofertado, as vantagens que o cliente obteria e a importância que aquele produto teria no aumento da qualidade de vida das pessoas a quem seria oferecido. Um deles, com cópias de legislações específicas, apontava que o produto estava de acordo com as exigências propostas pelos órgãos de fiscalização. Outros - sempre atentos aos olhares do gerente e do representante do cliente - lembravam também que haveria um custo diluído ao longo da execução das etapas do projeto. Cada cifra alta que era solta era logo seguida por alguma informação cativante, dada com maior ênfase, e que certamente conquistaria o cliente.

Do lado do gerente, um senhor parecia não se importar muito com a reunião, mexendo em sua pasta a maior parte do tempo, concentrando-se apenas quando Ihe dirigiam a palavra a respeito de empréstimos e financiamentos, retornos e liquidez, cartas de crédito e outros instrumentos que o banco que representava ali poderia fornecer para a negociação.

Havia também uma representante da prefeitura do município atenta aos benefícios que aquele produto traria à população, principalmente à imagem que a cidade passaria a ter com aquele produto, que certamente despertaria a atenção de muitos da região e até mesmo de outros cantos do estado, do país e, quiçá, de algumas partes do mundo. Ela se dispunha a facilitar alguns processos, para dar melhor dinâmica às negociações.

E havia o responsável pelo projeto, dono do desenho daquele produto, da proposta de organização - um arquiteto e urbanista.

O produto ofertado era um loteamento localizado na periferia da cidade. O empresário, dono da imobiliária onde estava sendo realizada a reunião, propunha acordos para viabilizar a construção. Seu gerente ficava de olho nas cifras, para tornar aquela negociação um bom investimento para a imobiliária. O proprietário da terra, apesar da 
figura de fazendeiro familiar, simples, bonachão e turrão, pertencia a uma das famílias mais importantes da cidade, com canaviais, usinas e destilarias espalhadas por outras cidades da região. Preocupava-se com sua produção e com o mercado que abastecia. O rapaz ao seu lado Ihe fornecia informações constantes sobre valorização e possíveis depreciações do açúcar no mercado financeiro mundial, sugerindo alternativas para o fazendeiro gerir suas estruturas da melhor maneira possível, sem correr riscos de ir à falência.

A representante da prefeitura acompanhava a discussão pensando na visibilidade da cidade com relação às outras da região e também no papel da cidade em específicos círculos de produção em nível nacional e internacional. Estava atenta, também, ao número de empresas que viriam a se interessar em se instalarem na cidade, tendo em vista as oportunidades de investimento para elas e a qualidade de vida fornecida pela cidade para acomodar a população trabalhadora que viria nesta mesma leva.

Os técnicos e o arquiteto buscavam propor alternativas convincentes para terem o projeto aceito e bem visto, pensando em ideias como sustentabilidade, economia de meios e facilidades construtivas. $\mathrm{O}$ arquiteto urbanista, especialmente, pensava na qualidade de vida daqueles que viriam a habitar as residências e apartamentos, na facilidade de deslocamentos, na comunicação com o restante da rede de mobilidade urbana que os moradores teriam e na qualidade dos espaços de trabalho dos grandes edifícios corporativos e das ruas de comércio do empreendimento.

De fato, aos empresários pouco importavam as consequências reais no espaço da cidade. Eles anotavam tudo para repassarem ao pessoal do marketing na próxima reunião para produção das peças publicitárias e de divulgação do empreendimento. Forçariam os técnicos e profissionais ao extremo para que o valor de produção fosse enxugado ao máximo, economizando na qualidade dos materiais, nos espaços dos apartamentos; exigindo aumento de lotes e unidades habitacionais em detrimento da qualidade do projeto (cuja imagem seria resgatada para fins publicitários posteriormente). Estava claro o que mais importava naquela reunião: o lucro das partes envolvidas.

A reunião narrada, apesar de fictícia, é uma realidade das mais comuns reproduzidas nas cidades quando o assunto é expansão urbana, correspondendo a um modus operandi bastante claro em suas intenções e negociações, popularizado a partir dos anos 1980. Ela des- 
taca figuras que correspondem a elementos essenciais para a compreensão dos processos de reprodução de cidade, sobretudo em regiões onde a propriedade da terra é fator essencial para a realização de atividades voltadas ao agronegócio brasileiro.

O agronegócio se constitui em importante braço do desenvolvimento do interior brasileiro. A produção de cana-de-açúcar se destaca correspondendo a uma das mais importantes do setor, responsável pela produção de açúcar para exportação e produção de álcool combustível para abastecimento da frota nacional de veículos. O litoral nordestino, da Bahia até Rio Grande do Norte, e a região centro-sul, que envolve os interiores de São Paulo, Paraná e Santa Catarina e os estados de Mato Grosso do Sul e Goiás, são as áreas responsáveis pela produção sucroalcooleira.

Assim, o agronegócio aproxima a esfera do campo (do cultivo, da produção de matérias-primas agropecuárias) à esfera urbana através da indústria (da produção de insumos e maquinários agrícolas e da transformação da matéria-prima em outros produtos de consumo). Para que toda essa cadeia produtiva se realize, o agronegócio necessita do território físico definido pelo setor primário e pelo território gerencial e mercadológico fornecido pela estrutura urbana, tanto para os negócios, quanto para os profissionais que atuam no setor, o que acaba contribuindo para uma reestruturação do espaço.

Devido ao seu caráter urbano, a produção agroindustrial e o agronegócio passaram a articular várias cidades e estruturas produtivas, extrapolando dimensões metropolitanas, redefinindo e até mesmo suprimindo as relações dicotômicas clássicas entre cidade e campo, urbano e rural. Uma vez redefinida a lógica de produção industrial, tal mudança redesenha e reconfigura os limites da tradicional relação cidade-campo, tendo em vista as recentes configurações econômicas e financeiras de um mercado que transpõe os limites regionais, considerando uma região que exporta uma produção específica.

A dinâmica da agroindústria no estado de São Paulo é configurada pelos complexos agroindustriais, compostos por indústrias de processamento, beneficiamento e produção de açúcar e derivados da cana (o caso do setor sucroalcooleiro), além de indústrias e empresas responsáveis pelo fornecimento de maquinário, tecnologias e insumos para a produção agrícola. A região de Ribeirão Preto é uma das, se não a principal responsável pela produção nacional de álcool, açúcar e laranja. A produção agrícola se constitui em esfera produtiva de grande 
relevância para o desenvolvimento das cidades dessa região, o que estabelece um ponto de relação entre reprodução de cidade e o uso da terra pela agroindústria, fundamental para a articulação do contexto de produção urbana e o agronegócio, tornando-se chave da eleição da região para este trabalho.

Aqui se pretende analisar a reprodução do espaço urbano e rediscutir os limites regionais da produção agrícola, tendo como foco a região de Ribeirão Preto, destacando o setor agroindustrial e o agronegócio como atores principais articulados a essa produção e reprodução urbanas no âmbito regional. O trabalho também buscará problematizar questões sobre processo de urbanização no contexto regional, destacando a agroindústria, o agronegócio, o setor imobiliário e o Estado enquanto atores essenciais nos processos de reprodução de cidade no interior do estado de São Paulo, considerando-os causas e/ou consequências, muitas vezes, de fatores externos à própria região.

É importante destacar dois fatores fundamentais para a pesquisa: atividade acadêmica anterior relacionada ao tema da pesquisa abordando, em um primeiro momento, políticas e programas públicos e, em um segundo, organização e definição de territorialidades; e a atuação profissional por parte do pesquisador dentro do setor imobiliário em Sertãozinho, compreendendo o papel atuação do arquiteto e do urbanista dentro de uma empresa imobiliária, e suas relações com diretores, clientes e demais profissionais e grupos relacionados a empreendimentos imobiliários na região. Tal experiência desencadeou uma série de questionamentos, dentre eles o de como são reproduzidas as cidades atuais na região de Ribeirão Preto. E adotando tal região como objeto, fez-se necessário a aproximação com a agroindústria sucroalcooleira para compreensão do fenômeno urbano ali analisado.

Foram efetuadas consultas no Arquivo Público e Histórico de Ribeirão Preto, na Secretaria de Planejamento Urbano de Ribeirão Preto, nas redes de bibliotecas da Universidade de São Paulo, da Universidade Federal de São Carlos e em importantes bases eletrônicas de dados destas e de outras instituições públicas de ensino, além de anais de eventos e revistas acadêmicas, artigos e reportagens de jornais regionais e temas específicos sobre dinâmica imobiliária, econõmica e financeira e demais temas abordados na pesquisa. Também foram utilizadas entrevistas com acadêmicos das áreas em questão e com profissionais atuantes no mercado na região de Ribeirão Preto além da participação nas audiências públicas sobre revisão do plano 
diretor de Ribeirão Preto, realizadas em agosto de 2013.

Ao longo dos capítulos um percurso se construiu na tentativa de encontrar relações entre a reprodução de cidade e o agronegócio. No primeiro capítulo serão inicialmente abordadas a noção de região, para que se possa esboçar a definição da região de Ribeirão Preto, tendo em vista processos anteriores ao recorte histórico abordado, como a Marcha para o Oeste e o ciclo cafeeiro, imprescindíveis para a compreensão da importância da agropecuária para a região e sua urbanização. Dar-se-á continuidade com a introdução da noção de rede urbana e da relação cidade-campo, tratando os processos de mecanização do campo e intensificação da industrialização e urbanização do país, decorrentes das crises do café no início do século XX e da substituição do café pelo açúcar enquanto principal produção agrícola para exportação, o que gerou uma necessidade de reestruturação produtiva da agricultura no país. Será discutida, ainda, a atuação do Estado neste processo, através do estabelecimento de complexos agroindustriais pelo país, organizando o território agrícola nacional a partir de especializações e espacializações da produção sucroalcooleira.

Uma vez preparada e semeada a terra e dado o tempo de maturação, é chegado o momento da colheita. Feita a análise do território, será analisado o processo de implantação dos complexos agroindustriais na região de Ribeirão Preto e suas especificidades regionais, além de suas consequências no âmbito urbano, como o processo de urbanização e do aumento populacional a partir dos anos 1980. Também serão abordados a exploração dos trabalhadores nos canaviais e os conflitos do setor agroindustrial, que são incorporados à realidade urbana da região, dando continuidade à questão da relação cidadecampo. Em seguida, será inserido o conceito de região metropolizada na tentativa de compreender o papel da região de Ribeirão Preto na escala da rede urbana e a importância de sua economia em nível estadual.

Com a matéria-prima em mãos, serão iniciados os processos de beneficiamento e produção da mercadoria final, assim como a definição de quem a produziu. No terceiro capítulo serão abordadas as dimensões neoliberais e suas relações com o Estado na produção sucroalcooleira nacional, bem como o aumento da atuação de empresas familiares no setor, articulando-se e controlando a produção. Em seguida, serão aprofundadas as informações sobre a dinâmica do setor e os processos de fusão e aquisição entre empresas e famílias brasilei- 
ras enquanto alternativa para contornar os efeitos da crise do açúcar no início dos anos 2000 e a redução do interesse do mercado internacional no etanol. As fusões entre empresas nacionais e estrangeiras também teriam sido mais uma alternativa, marcando o processo de transnacionalização do setor sucroalcooleiro. Tais processos desencadearam concentrações econômica e fundiária, comprometendo a agricultura familiar, o abastecimento interno e se aproximando da reprodução urbana com a presença dos latifúndios.

Após todo o processo de produção, encaminha-se para o fim da cadeia, com as etapas de negociação e distribuição da produção pelo mundo, pautadas na dinâmica do mercado e das bolsas de valores. Mas, afinal, o que está sendo produzido? E para quem? No capítulo final serão apresentados o mercado e a mercadoria, elementos essenciais para a justificativa disso tudo. Serão abordados o agronegócio e sua relação com os mercados internacionais de commodities agrícolas através da esfera financeira e o apadrinhamento do setor sucroalcooleiro por empresas de outros setores de produção agrícola, como alternativa de sobrevivência das unidades produtivas do setor, e também de outras empresas de setores relacionados à securitização, crédito à produção agrícola e à exploração da terra. Através das operações de crédito e da dinâmica empresarial no mercado financeiro, serão aproximados o agronegócio e o mercado imobiliário, analisando o processo de reprodução das cidades, tomando como foco as cidades de Ribeirão Preto e Sertãozinho, culminando na questão da terra enquanto um dos principais denominadores comuns entre agronegócio e mercado imobiliário financeirizados.

Por fim, a pesquisa buscará tecer uma teia de conflitos e questões que permeiam a discussão da reprodução do espaço urbano, buscando compreender quais processos e estruturas transpassam a reprodução do espaço urbano e a expansão de algumas cidades, tendo em vista o contexto regional ribeirão-pretano. 


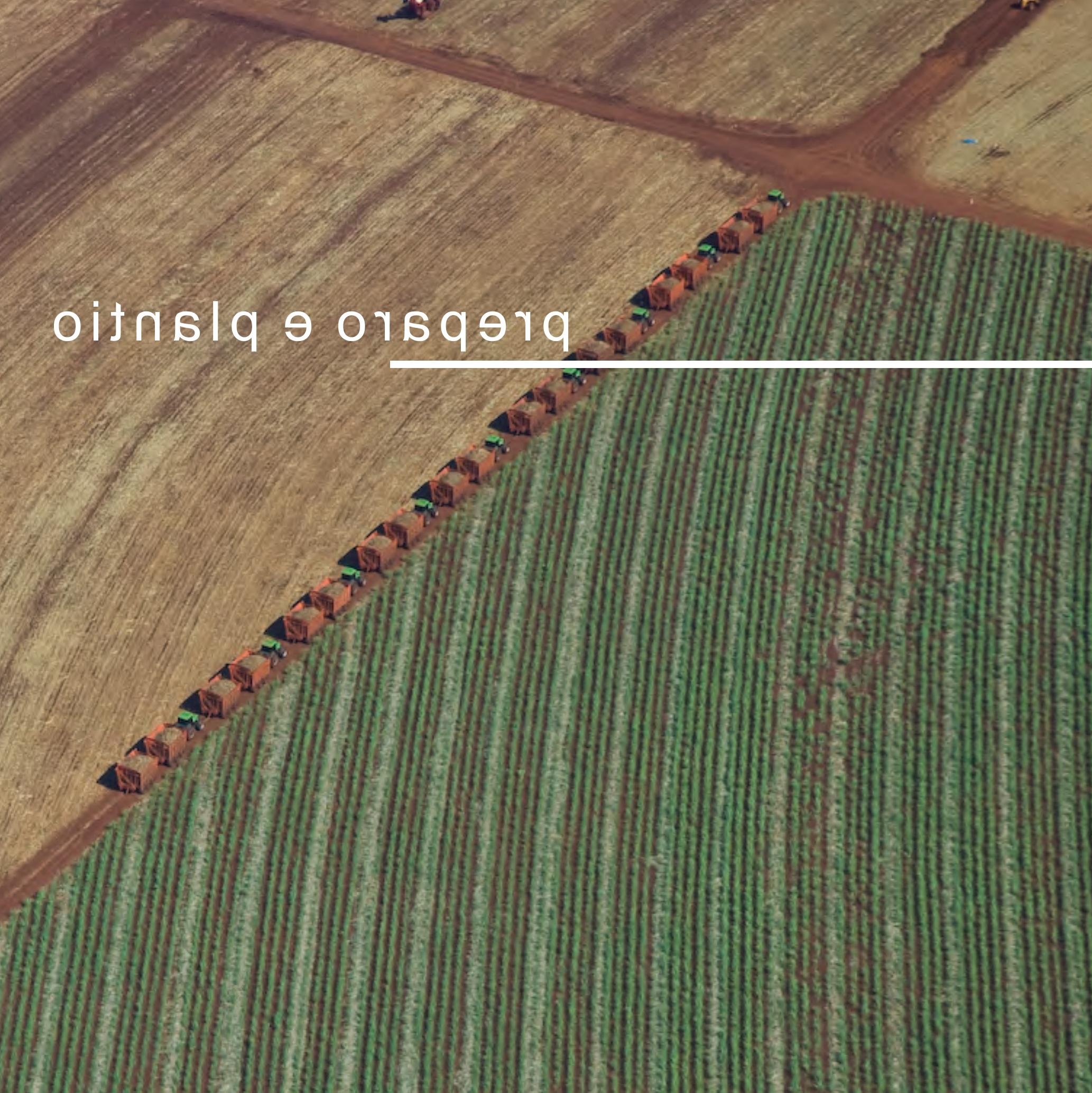
preparo e plantio 
A CONSTRUÇÃO DO TERRITÓRIO
A atual produção de loteamentos urbanos nas franjas de algumas das cidades que compõem a região administrativa de Ribeirão Preto, bem como a experiência e participação neste processo compõem o principal ponto de partida que desencadeou uma série de questões que serão analisadas neste trabalho. Localizada a nordeste do estado de São Paulo, a região é reconhecida pela participação de sua agroindústria no setor sucroalcooleiro e sua atuação no agronegócio, o que permite, deste modo, articular tais relações socioeconômicas à discussão da reprodução urbana no território. A influência de Ribeirão Preto configura uma espécie de rede entre as cidades, o que permite tomar como objeto inicial de análise a região administrativa de Ribeirão Preto em sua atual delimitação.

Incialmente é necessário definir qual ideia de região está sendo tratada. O termo é bastante frequente no âmbito da Geografia e possui um histórico de discussão amplo e uma infinidade de significados. A ideia não é discutir o termo, mas buscar compreendê-lo, assim como o modo em que será utilizado a partir de então neste trabalho. Afinal, a análise se inicia a partir da região administrativa de Ribeirão Preto. Mas o que é essa região? O que a define e conforma? 
No século XIX, Ritter utilizou critérios naturais para a definição de uma região, analisando seu relevo, clima, população e atividades humanas, propondo o caminho da indução. No Brasil, o professor Candido Mendes de Almeida no mesmo período organizou o Atlas do Império do Brasil, no qual aparecia um Brasil analisado sob quatro pontos de vista, indicando que as divisões administrativas concebidas constituíam esferas do poder sobre o território brasileiro. Na Europa, a discussão na Geografia sobre a definição do termo região foi avançando, buscando encontrar um ponto fundamental entre a polarização que contrapõe leis gerais com base nos aspectos da natureza (Humboldt) e aspectos da vida social e cultural incorporados a uma dimensão histórica (Ritter), até culminar na proposta de que a região é "o espaço com características físicas e socioculturais homogêneas, fruto de uma história que teceu relações que enraizaram os homens ao território e que particularizou este espaço, fazendo-o distinto dos espaços contíguos"1. Ela pode ser definida objetivamente pela paisagem e pela consciência humana dessa paisagem, construindo identidades regionais.

Em fins do século XIX e início do XX, Vidal De La Blache incorporou à Geografia o conceito de "gênero de vida", definido pelo resultado das influências físicas, históricas e sociais presentes na relação entre homem e meio. E Paul Claval sintentizou o pensamento lablachiano, considerando primeiramente que as regiões se evidenciam na superfície terrestre. A segunda consideração é a de que as relações físicas e culturais (organização social e econômica) se traduzem na paisagem; e a terceira, a de que os agrupamentos humanos tomam consciência das especificidades que distinguem uma região da outra, reconhecem a divisão, nomeiam-na e a utilizam na criação de quadros político-administrativos.

O conceito de região é ainda bastante discutível na Geografia, uma vez que o termo pode abranger diversos significados de acordo com a esfera em que ele é utilizado, com o contexto ou enquanto palavra-chave de um sistema explicativo. Eis a justificativa de por que o termo sempre aparece adjetivado (região natural, montanhosa, administrativa, de pobreza, de cultura, de produção, de cultivo, etc.).

Para compreender o papel de destaque e a importância da região de Ribeirão Preto no atual contexto de produção agroindustrial e do agronegócio, é necessário destacar alguns aspectos que chamaram a atenção para a região durante o período do café no século XIX. Historicamente, o interior do estado paulista apresentava certas vanta- 
2. Ainda que a cultura do café (responsável por tal progressão) tenha tido início em partes montanhosas do estado do Rio de Janeiro em meados do século XIX, passando pelo vale do Paraíba do Sul até chegar a terras paulistas, sendo expandida pelo interior de São Paulo somente na segunda metade do mesmo século, intensificando o movimento e alcançando os planaltos ocidentais por volta de 1870-1880.

3. Dados extraídos de MONBEIG, Pierre. Pioneiros e fazendeiros de São Paulo. São Paulo: Ed. Hucitec-Polis, 1984. gens, dadas suas condições naturais (como relevo, clima, qualidade do solo, vegetação, temperatura) relacionadas às necessidades, hábitos e meios técnicos de que dispunham os produtores rurais, e suas condições históricas, sobretudo pelo fato de a "Marcha para o Oeste" ter sido impulsionada a partir da cidade de São Paulo ${ }^{2}$, produzindo cidades no interior do estado paulista até a primeira crise do café, em 1905. Desde seu início, a Marcha para o Oeste não foi algo meramente local ou brasileiro, mas correspondeu a um episódio da expansão da civilização capitalista - em linhas lefebvrianas, contribuindo para a constituição de uma sociedade urbana através do processo de urbanização do espaço. As crises sinalizadas durante o período em que o café era o carro-chefe da economia brasileira já indicavam a finalidade e concentração de um comércio exportador e a influência e poder de organizações estrangeiras (no caso, de casas de exportação estrangeiras).

As vantagens que a região de Ribeirão Preto apresentou para a economia ca-feeira contribuíram enquanto fator essencial para que ela se tornasse uma das primei-ras regiões de produção sucroalcooleira, sobretudo pelo solo formado por terra roxa e basalto, o que atraiu os fazendeiros para a localização de cafezais produtivos (ver Figura 1). A região correspondia a uma das maiores extensões de terra roxa do planalto paulista, denominado "maciço" de Ribeirão Preto. Compreendia os cafezais de Batatais, Jardinópolis e Nuporanga ao norte, e ao sul os cafezais de Ribeirão Preto, Sertãozinho, São Simão, Cravinhos e Santa Rita do Passa Quatro, somando cerca de 110 milhões de cafeeiros, entre 1900 e 1905, podendo-se somar 7 milhões que havia em Franca e 1 milhão em Ituverava. O municí-pio de Ribeirão Preto era o mais procurado pelos imigrantes (por onde passaram cerca de 14.290), uma vez que era considerado um dos grandes centros cafeicultores, juntamente com São Simão, São Carlos, Araraquara e Jaú ${ }^{3}$. Comparando com outras áreas de cafezais do estado, mostradas na figura 2, nota-se que as características físicas privilegiadas permitiram uma maior produção de café, impulsionando a econo-mia da região e destacando-a das demais. Têm-se aqui os elementos que a definiram enquanto região: os atributos físicos (sobretudo o solo de terra roxa), a organização social e econômica (a cultura do café), o reconhecimento de suas especificidades pe-los agrupamentos humanos e o estabelecimento de um quadro de controle e domina-ção (os fazendeiros e proprietários de terra).

A região de Ribeirão Preto foi uma das primeiras a se expor 
4. Desenvolvida ao longo dos anos 1970 e 1980 em resposta a tendências neopositivistas internas à própria geografia, trata-se de uma vertente da geografia que se baseia principalmente na teoria crítica para as análises geográficas, propondo o rompimento com a ideia de neutralidade científica, tendo como principais expoentes David Harvey, Yves Lacoste, Horacio Capel e, no cenário brasileiro, Milton Santos e Ana Fani Carlos.

5. É importante assinalar que existe a possibilidade de dupla grafia da palavra "socioespacial", tendo em vista as regras do novo acordo ortográfico da Língua Portuguesa. O termo "socioespacial" se refere somente ao espaço social construído em determinado momento histórico, real ou potencial, tal como um plano de remodelação urbanística. Já "sócio-espacial" diz respeito às relações sociais e ao espaço simultaneamente, abrangendo a dinâmica da produção do espaço no contexto da sociedade concreta como totalidade (SOUZA, 2009, p. 24-25).

6. Outro exemplo de que a territorialização econômica transpassa limites regionais administrativos é o Mercosul, que busca integrar mercados produtores e consumidores latinos, para além das fronteiras físicas entre os países membros. aos processos de modernização, já então considerada importante devido às vantagens para produção agrícola e ao seu dinamismo econômico durante a produção cafeeira. No fim do século XIX, era a principal região produtora do estado e assim desenvolveu outras atividades econômicas, produzindo e desenvolvendo outras cidades na região para atenderem às necessidades das relações de produção exigidas pelas culturas e sua exportação.

Derivada do latim regere, composta pelo radical reg (que originou outras pa-lavras como regente, regência, regra), o termo região, do ponto de vista das relações humanas, pode ser visto como uma relação entre a centralização de um poder em um local e a extensão dele sobre uma área de grande diversidade social, cultural e espacial. Do ponto de vista da análise regional, destaca-se a noção de região funcional (ou região polarizada), que busca analisar o espaço através das múltiplas relações que circulam e dão forma a um espaço internamente diferenciado, valorizando o papel da cidade como centro de organização espacial, definindo sua hinterlândia e organizando e articulando outros centros urbanos, configurando assim um espaço tributário e um sistema espacial (GOMES, 2000). Entretanto é importante ressaltar que não é a cidade em sua totalidade que exerce tal influência, mas setores e atores específicos que a compõem (instituições públicas, empresas, sociedade civil, trabalhadores, etc.), cujas atividades estão fortemente relacionadas à região de análise.

Segundo a vertente da geografia crítica ${ }^{4}$, a diferenciação do espaço se deve à divisão socioespacial do trabalho "e ao processo de acumulação capitalista que produz e distingue espacialmente possuidores e despossuídos" (GOMES, 2000). Deste modo, a regionalização pressupõe a noção de territorialidade, uma vez que articula relações de poder, domínio e controle no e do espaço. Assim, o território projeta as relações sociais no espaço, articulando atores sociais e a maneira como dominam ou influenci-am tal espaço. Ele pressupõe uma contiguidade espacial controlada (por exemplo, o tecido urbano da cidade de Ribeirão Preto, a área definida como estado de São Paulo, ou uma propriedade particular de uma empresa sucroalcooleira, ou uma região administrativa).

O uso e o controle do território podem ser empregados inclusive na formulação de estratégias de desenvolvimento sócio-espacial ${ }^{5}$, contribuindo para uma maior justiça social, para além do crescimento econômico ${ }^{6}$ e modernização tecnológica. $O$ território também é dotado 
de temporalidade, podendo alterar sua configuração e seus limites ao longo do tempo, ou das estratégias de organização e administração. "As divisões não são definitivas, nem pretendem inscrever a totalidade da diversidade espacial, elas devem simplesmente contribuir para certo entendimento de um problema, colaborar com certa explicação" 7 .

A noção de território, portanto, pressupõe um controle do espaço. A ideia de rede surge diretamente relacionada à organização espacial (território, região, nação) estabelecida enquanto sistema de comunicação de diversas ordens: integração produtiva, de mercados, de informações, financeira, através de estratégias de circulação e informação. A rede é o instrumento do poder por excelência, pois são as redes que reestruturam e balizam todo o território, permitindo a comunicação e os fluxos (de pessoas, de informação, de bens, de capital) entre as estruturas físicas nele instaladas. As relações piramidais de proximidade física e hierarquia de transmissão de poderes, e a interdependência à longa distância perderam forças com a nova representação que a ideia de rede produziu, na qual as cidades passaram a se estabelecer enquanto nós em um grande sistema urbano, estabelecendo elos entre macro-organizações e economias locais.

Segundo DIAS (2000), "a história da constituição da rede urbana brasileira é marcada pela associação entre processo de urbanização e processo de integração do mercado nacional"'. Após a crise do café nos anos 1905, a Marcha para o Oeste deixou de ser exclusivamente a marcha do café. Ainda assim continuou sua expansão não apenas com os cafezais, mas também através de outras culturas, como a produção de algodão como alternativa à necessidade de alteração da base econômica agrícola, e também a pecuária, enfatizada com a construção de um frigorífico na cidade de Barretos no mesmo período, fundado por Antônio Prado, grande fazendeiro e animador da expansão ferroviária, que continuava seguindo pelo estado chegando às fazendas produtoras. Sinalizava-se, portanto, uma diversificação econômica por parte dos proprietários de terra, em uma tentativa de se adaptarem às condições econômicas e tirar o melhor partido das propriedades através da pecuária. Mas tal diversificação não consistia apenas na alternância entre subsetores da produção rural. Com a crise, a venda de grandes propriedades era praticamente impossível. Deste modo, grandes proprietários de terra se associaram a empresas estrangeiras para dividir suas grandes propriedades e comercializar pequenas frações de terra, encorajando a cultura de algodão e agropecuária a novos e
7. GOMES, 2000, In: CASTRO, CORREAA, GOMES, 2000, p. 63

8. DIAS, L. Redes: emergência e organização. In: CASTRO, I.; CORRÊA, R.; GOMES, P. C. (Orgs.). Geografia - conceitos e temas. Rio de Janeiro: Bertrand Brasil, 2000. 
9. Apesar do recorte histórico desta pesquisa analisar a reprodução de cidades e a relação com o agronegócio a partir dos anos 1970, faz-se imprescindível uma análise dos períodos anteriores para poder compreender e concluir algumas questões atuais. 0 mercado imobiliário tal qual o conhecemos hoje, salve suas reestruturações e reformulações, não se difere muito dos séculos anteriores.

10. Apesar da marcha pioneira ter expandido a produção agrícola para oeste de São Paulo, as áreas de terra roxa, mais consolidadas, ainda assim receberam pouco mais de $20 \%$ desse contingente, sendo $16 \%$ ainda voltados para Ribeirão Preto, pequenos proprietários, movimentando, assim, capital na esfera imobiliária ${ }^{9}$. O preço dos lotes passou de 300 mil-réis o alqueire, em 1913, para 2.000 mil-réis em 1928.

A atuação do mercado imobiliário no processo de fragmentação de grandes propriedades foi um dos grandes fatores que contribuíram para a continuidade da Marcha para o Oeste. Tal processo de ocupação, a expansão ferroviária e a ocupação do que posteriormente veio a ser definido estado de São Paulo já indicavam a definição e estruturação do espaço através da composição de uma rede. Esta rede possuía um polo de irradiação na capital paulista, permitindo a distribuição de fluxos entre as cidades e a ocupação do território, sendo idealizada para contemplar os próprios fazendeiros e a produção de seus cafezais. As figuras 2 e 3 mostram, respectivamente, o direcionamento dos rendimentos da produção cafeeira no início do século XXe, em um momento posterior, com a economia já consolidada e às vésperas da crise de 1929. É importante notar que, além do processo de expansão da monocultura, também ocorreu um deslocamento espacial dos rendimentos. Inicialmente, os solos mais férteis constituíram as primeiras áreas de produção. A região de Ribeirão Preto e a de Bauru foram as que mais produziram (acima de 75 arrobas por 1.000 pés plantados), definindo, juntamente com a região de Campinas, um território de maior produtividade. Contudo, dada a produção excessiva de tal região, os solos para a cultura cafeeira se desgastaram, fazendo com que a economia cafeeira expandisse sua área e produção por todo o território do estado. Tal ampliação das áreas de cultivo com a formação de novas fazendas permitiu também ampliar a distribuição dos imigrantes que compunham grande parcela de trabalhadores dos cafezais. As imagens 4 e 5 mostram o destino da mão-de-obra imigrante no estado em fins do século $\mathrm{XIX}$, sendo direcionadas às regiões de Jaú, Araraquara, Jaboticabal e Ribeirão Preto; e sua distribuição no fim da década de 1920 , sendo redistribuídas a novas regiões produtivas, principalmente ao longo do eixo Piratininga-Araçatuba. Entre 1926 e 1930, as zonas agrícolas do interior de São Paulo receberam um contingente de 233.202 trabalhadores estrangeiros e nacionais. O conjunto de imagens acaba evidenciando não apenas uma temporalidade da conformação socioeconômica do território, mas também o papel de destaque na produção cafeeira e polarizador de recursos e imigrantes da região de Ribeirão Preto ${ }^{10}$, revelando sua importância na rede, assim como também é notável o pro- 
Figura 2 - Rendimentos do café no estado de São Paulo, de 1912 a 1918.

Fonte: MONBEIG, Pierre. Pioneiros e fazendeiros de São Paulo, p. 189. São Paulo: Ed. Hucitec-Polis, 1984.

Figura 4 - Localização dos Imigrantes que passaram pela Hospedaria de Imigrantes de São Paulo em 1898-1902.

Fonte: MONBEIG, Pierre. Pioneiros e fazendeiros de São Paulo, p. 173. São Paulo: Ed. Hucitec-Polis, 1984.
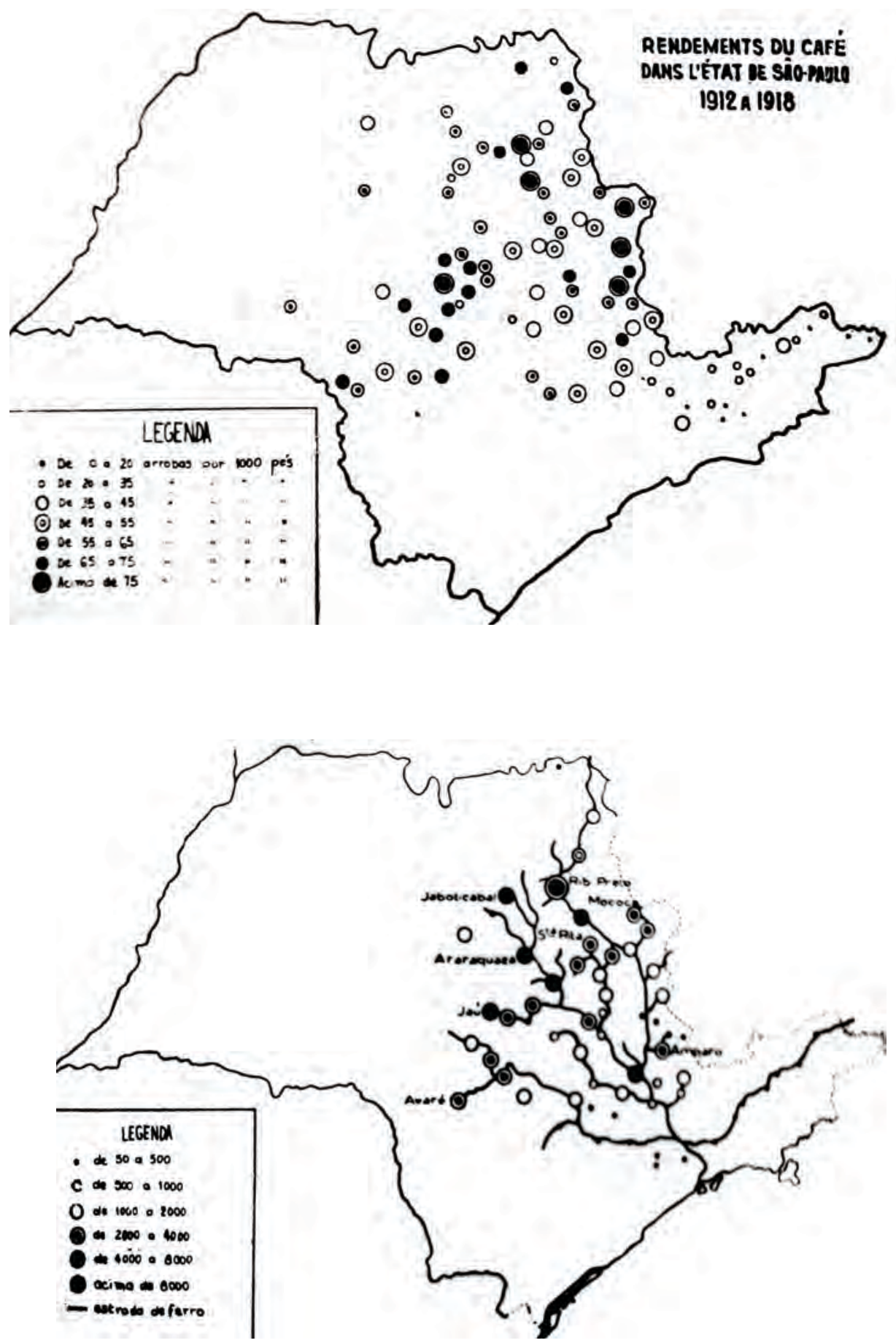

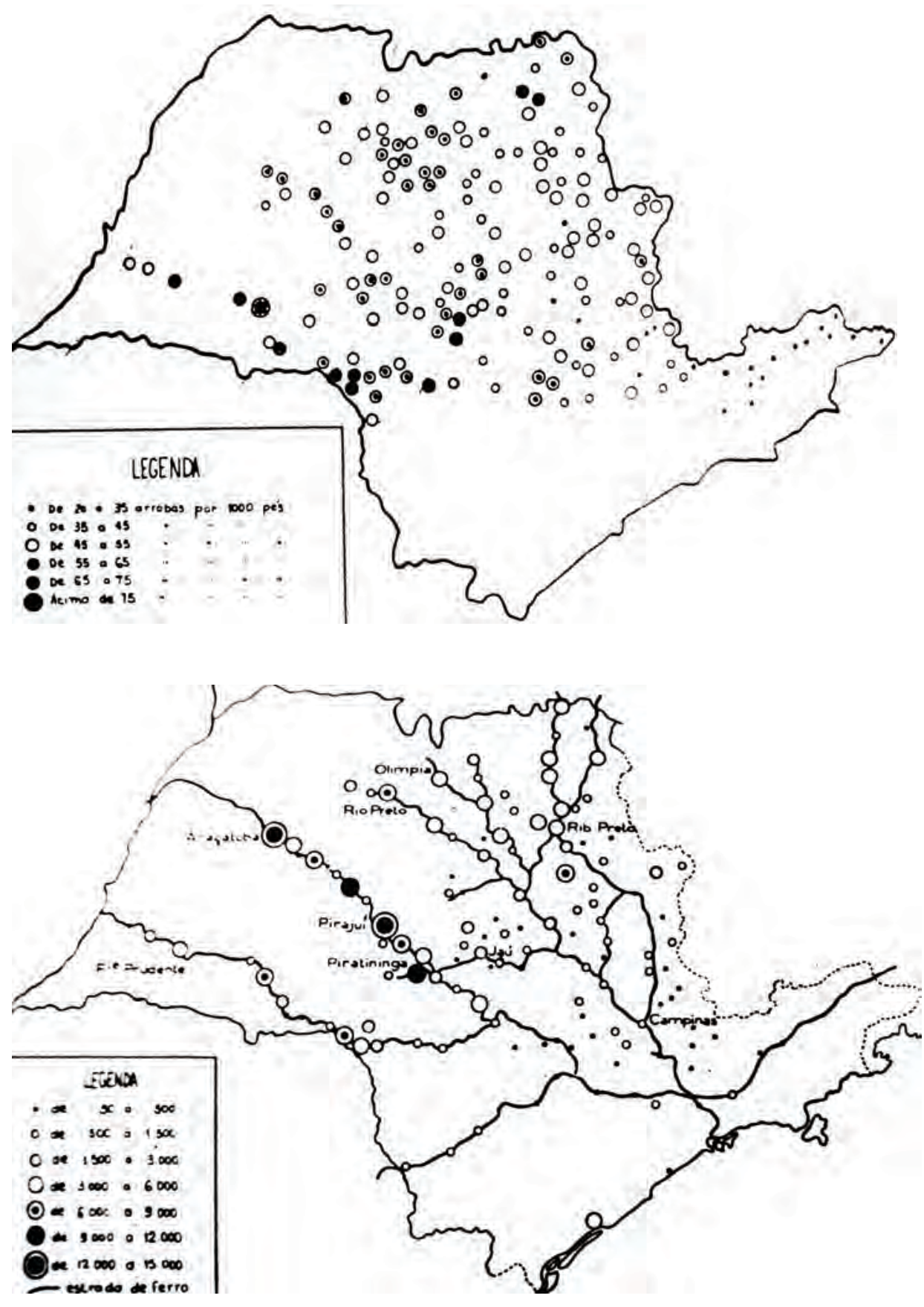

Figura 3 - Rendimentos do café no estado de São Paulo, de 1926-27 a 1930-31.

Fonte: MONBEIG, Pierre. Pioneiros e fazendeiros de São Paulo, p. 190. São Paulo: Ed. Hucitec-Polis, 1984.

Figura 5 - Localização dos Imigrantes que passaram pela Hospedaria de Imigrantes de São Paulo em 1926-1930.

Fonte: MONBEIG, Pierre. Pioneiros e fazendeiros de São Paulo, p. 194. São Paulo: Ed. Hucitec-Polis, 1984. 
cesso de ocupação do território através da produção de novos estabelecimentos rurais.

A relação entre agricultura, empresa e loteamentos não é nenhuma novidade provinda do advento da reestruturação da ordem mundial que viria com o pós-1970. Três grandes grupos possuíam interesse na colonização do interior paulista após a crise de 1929 e passaram a atuar no território e a controlar a dinâmica da colonização e do processo de desmembramentos: a Companhia Paulista de Estradas de Ferro, a Sociedade Colonizadora Brasileira e a Companhia de Terras do Norte do Paraná. A Companhia Paulista de Estradas de Ferro era constituída por ricos fazendeiros que viram nas estradas de ferro um meio de assegurarem a produção de seus cafezais. Para atender à demanda e necessidade de escoamento da produção e dos trabalhadores, todo o território se encontrava irrigado por redes ferroviárias e rodoviárias, conforme disposto na figura 6, em que as fazendas de café se irradiam a partir das proximidades da capital paulista, conectadas à região de Campinas e ao porto de Santos através de ferrovias, em fins da década de 1920. Posteriormente, a companhia adquiriu uma empresa de transportes rodoviários, a CAIC - Companhia Agrícola de Imigração e Colonização. Assim sendo, a construção das estradas de ferro e a malha rodoviária foram organizadas de modo a atender aos interesses desses grandes proprietários.

Em 1929, a Sociedade Colonizadora Brasileira, inteiramente japonesa, marcava a presença de estrangeiros no processo de colonização de terras e no mercado imobiliário associado a atividades relacionadas à exploração de produção de núcleos coloniais, articulando cooperativas agrícolas (esfera da produção) e de um banco (esfera financeira). Ela mesma produzia tecnologia para beneficiar sua própria produção. No que diz respeito ao valor da terra e à relação com a localização (proximidade de equipamentos públicos e infraestrutura), o caráter especulativo se mantém ${ }^{11}$. Após a Segunda Guerra Mundial, o alqueire, que próximo a Presidente Prudente custava de 6 a 8 mil cruzeiros, caía para 5 mil em Pirapozinho, a menos de $30 \mathrm{~km}$ ao sul, em solo propício aos cafeicultores ${ }^{12}$.

Com a crise de 1929, os principais estabelecimentos bancários se transformaram em proprietários de terras. A posse das terras só conseguiu ser recuperada pelos fazendeiros com a lei do Reajustamento Econômico na década de 1930, que reduziu a 50\% as hipotecas agrícolas e dívidas contraídas pelos lavradores junto aos ban-

\section{MONBEIG, 1984.}

12. Idem, p. 228. Grupos ingleses, durante a década de 1920, tinham a intenção de adquirir grandes extensões de terra no Brasil para transferir a produção de algodão que possuíam no Sudão, cuja situação política era inquietante e comprometedora para os negócios ingleses (MONBEIG, 1984). Através de estudos, concluíram que era mais interessante investir em companhias de colonização, cujos pequenos proprietários que seriam instalados se tornariam produtores de algodão, gerando capital que seria convertido em lucro para as empresas. A partir de 1937, as políticas no Brasil dificultaram o acesso repasse dos lucros a acionistas britânicos, controlando severamente a exportação de capitais e sobretaxando os ganhos estrangeiros. Os acionistas estrangeiros optaram por vender suas ações a grupos banqueiros paulistas e empresas de colonização, como a Companhia de Terras do Norte do Paraná, tornaram-se nacionais, sem perder o caráter de empreendimento puramente comercial. Configurava-se assim uma importante relação entre produção agrícola e loteamentos enquanto alternativa de obtenção de lucros. 


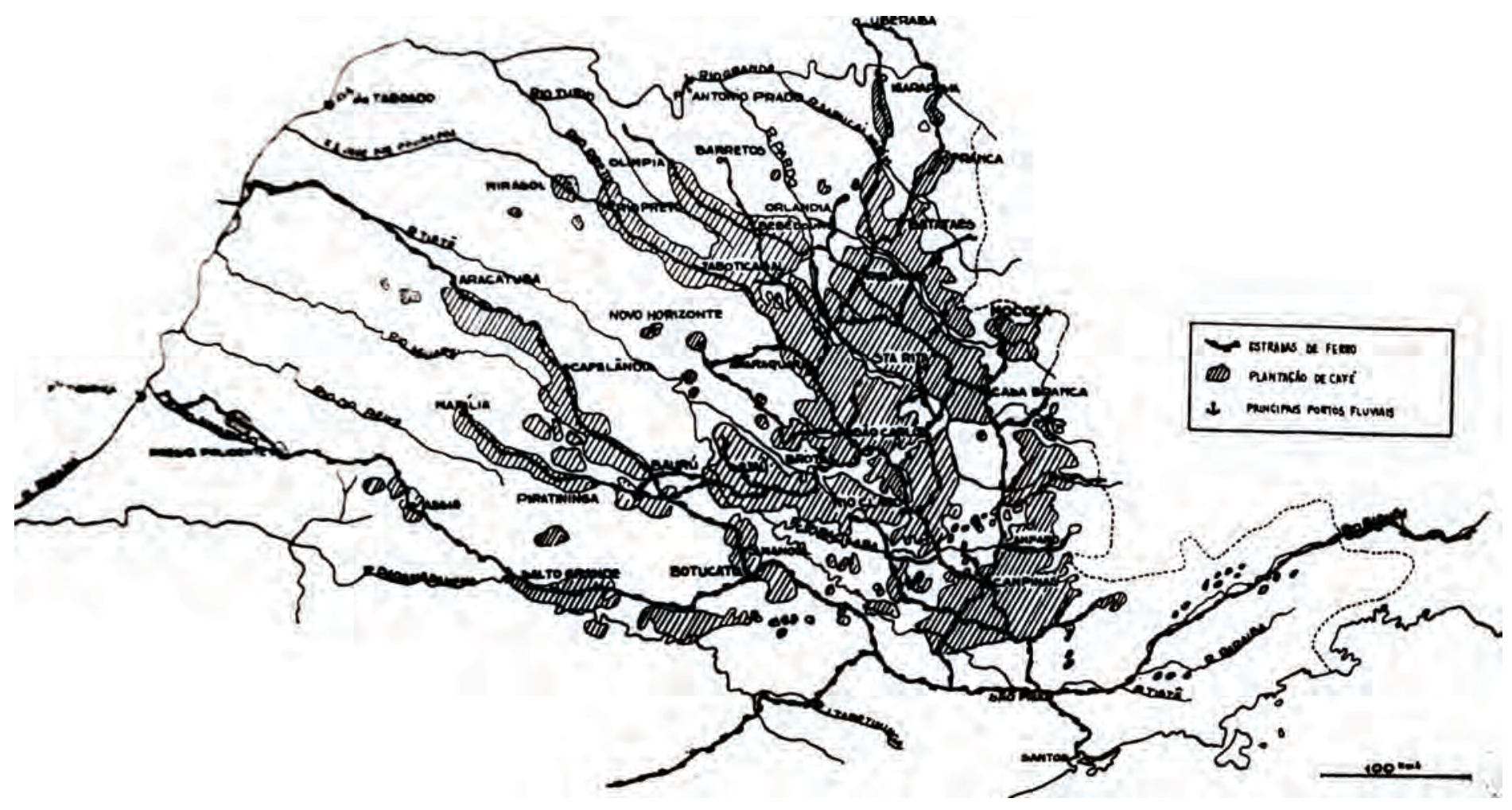

Figura 6-Cultura do café e vias férreas às vésperas da crise de 1929. Fonte: MONBEIG, Pierre. Pioneiros e fazendeiros de São Paulo, p. 186. São Paulo: Ed. Hucitec-Polis, 1984. 
cos. Com o café em crise, a solução foi alterar a produção agrícola para a cultura de algodão. Porém a venda de grandes e contínuas extensões de terra estava abalada demais para ser feita. Como alternativa, passou-se a comercializar pequenas parcelas para imigrantes, trabalhadores de plantações arruinadas, colonos que sofreram menos que seus patrões com a crise. E assim a crise desenhou um clima favorável à expansão do povoamento, e municípios voltaram a surgir a partir de 1937. Deste modo, as crises no sistema econômico mundial afetaram diretamente a produção agrícola brasileira e, consequentemente, a reprodução das cidades. Coube aos fazendeiros e ao Estado criar mecanismos para culturas exportadoras de substituição, de modo a amortecer os choques de acontecimentos internacionais. A venda de terras passou a se mostrar desde já como alternativa econômica viável para investimentos em situações pós-crises.

No início dos anos 1930, a economia cafeeira já decretara sua falência em virtude da crise que assolou o mercado mundial. Como alternativa econômica, optou-se pela substituição da monocultura cafeeira pela produção de açúcar como principal produto de exportação.

Pensar a territorialidade sucroalcooleira nacional, bem como o processo de industrialização do setor, é indissociável das intervenções do Estado brasileiro. Não há como falar de um sem recorrer ao outro. Os interesses agroexportadores do Estado na produção do setor eram tão intensos quanto a necessidade de investimentos estatais solicitada por usineiros e indústrias relacionadas ao setor - as chamadas agroindústrias $^{13}$. Tais processos só foram legitimados através da instituição de órgãos federais e programas de políticas públicas por parte do Estado. Sendo assim, em 1933, foi criado o Instituto do Açúcar e do Álcool - IAA -, incentivado por usineiros e produtores do setor. Tinha como principais funções absorver o impacto gerado por uma crise de superprodução do setor, reorganizando os mercados internos; definir as bases para o aumento da produção alcooleira nacional, através de financiamentos de destilarias anexas às usinas de açúcar; incentivar o consumo e regular o mercado de açúcar e álcool, sendo o principal mecanismo de regulação a implantação de cotas de produção; e consolidar a participação do Brasil no mercado mundial enquanto exportador da commodity.

A atuação dos usineiros e empresários, bem como a articulação com o Estado foi de grande importância para a consolidação do

\section{REESTRUTURAÇÕES PRODUTIVAS}

13. Caracteriza-se enquanto agroindústria as indústrias cuja produção de bens esteja relacionada à produção agropecuária, desde etapas anteriores ao plantio - como insumos agrícolas, pesticidas, tecnologias associadas às engenharias, máquinas de aragem - passando pelas etapas de plantio e colheita - como máquinas, produção de silos, tratores - e chegando às etapas de pós-produção e beneficiamento que antecedem a exportação - refinarias, usinas, indústrias alimentícias, têxteis, de calçados, dentre outras que utilizam a matéria prima agrícola para produção de bens de consumo. 
14. A partir de 1973, passou a ser denominado Programa de Apoio àAgroindústria Açucareira.

15. O ESTADO DE S. PAULO. Planalsucar estimulou etanol no país. Caderno de Economia. Novembro, 2010. Disponivel em:

$<$ http://economia.estadao.com.br/noticias/geral,planalsu car-estimulou-etanol-no-pais-imp-,642600>.

Acesso em 12/06/2014.

16. ELIAS, 2003, p.170. setor no território. Em 1959, os usineiros paulistas criaram a Cooperativa Central de Produtores de Açúcar e Álcool de São Paulo, que negociava empréstimos e ajudava na comercialização com a criação de novas marcas de venda final do açúcar. A partir dos anos 1960, a política de desenvolvimento da agroindústria canavieira paulista se focou na ampliação das lavouras de cana-de-açúcar e no parque industrial açucareiro, tendo em vista o rompimento de relações entre os Estados Unidos e Cuba, sendo este último o principal país exportador de açúcar até o pós-guerra. Tal rompimento permitiu a inserção do açúcar brasileiro no mercado mundial, fator que permitiu à indústria sucroalcooleira se destacar e absorver recursos para produção e exportação de açúcar brasileiro para grandes mercados exteriores. $\mathrm{O}$ aumento da demanda e da produção açucareira exigiu uma série de políticas a serem trabalhadas em dois aspectos fundamentais: a ampliação das áreas de cultivo e a otimização das matériasprimas para aumento da produtividade. Entre 1963 e 1964, o IAA elaborou o Plano de Expansão da Indústria Açucareira Nacional, que deu origem a uma série de outros programas que seriam colocados em prática na década seguinte, tais como o Programa de Racionalização da Agroindústria Açucareira (em $1971^{14}$ ), através da poupança criada pelo fundo de exportação após a disparada do preço do açúcar no mesmo $a_{n}{ }^{15}$, visando à melhoria da qualidade da matéria-prima e à racionalização da produção e exportação, articulado aos programas de construção de terminais açucareiros nos portos de Recife, Maceió e Santos financiamentos da fusão e racionalização de empresas canavieiras.

Para isso, o Estado adotou estratégias de reconfiguração do território produtivo, concentrando os setores industriais relacionados diretamente com a produção agrícola, configurando os chamados complexos agroindustriais. Constituem-se enquanto parques industriais compostos por vários setores de indústrias que se desenvolvem "atreladas à agricultura moderna, desde o que produzem insumos e bens de capital para a mudança de sua base técnica (...), quanto a de processadores dos produtos agropecuários"16. Estabelecem-se enquanto estruturas essenciais entre produção agrícola, produção industrial e produção do urbano. Verificada tal relação entre indústria e produção agrícola, e o processo de urbanização que se vincula a essa aproximação entre esferas primária e secundária, principalmente em regiões cujas economias estão intrinsecamente relacionadas à agropecuária e onde cada vez menos se define com clareza o que é o território do campo e 
qual é o da cidade, recuperar a discussão sobre a relação cidadecampo é extremamente importante ${ }^{17}$. É possível, assim, observar como a sociedade e a vida urbana penetraram nos campos, comportando sistemas de objetos e de valores precisamente urbanos ${ }^{18}$. A indústria impôs sistematicamente uma homogeneidade metódica, em nome da razão, da lei, da técnica, do Estado e da hegemonia burguesa. A relação dicotômica cidade-campo se desfez, pois "as novas relações de produção (...) apagaram a distinção entre a cidade e o campo e permitiram que a 'segunda natureza' da industrialização se estendesse aos domínios mais distantes do meio ambiente" ${ }^{\prime 19}$. Assim, a produção do campo foi reestruturada e reincorporada ao sistema capitalista, garantindo a necessária expansão de processos de capitalização no território. O cultivo do campo passou a se estabelecer como etapa de obtenção de matéria-prima para processos de produção industriais, assim como demandadora de produtos industriais para sua realização, tornando-se totalmente submissa à realidade industrial, transformando-se "em empresa industrializada, global, de corporações gigantescas que produziam alimentos em massa para auferir lucro"20. Neste ponto, a agroindústria possuiu papel essencial na reconquista da agricultura pela indústria, de modo que o capitalismo uniu novamente o que historicamente ele havia separado para poder se desenvolver, reunificando dialética e contraditoriamente ambas as esferas, auferindo simultaneamente lucro e renda capitalista da terra ${ }^{21}$. A produção agrícola passou a fazer parte da realidade urbana, pelo viés industrial, tornando-se força motriz de uma economia também urbana, passando a usufruir de investimentos em tecnologia, tal como qualquer outra atividade capitalista. Tornou-se uma verdadeira linha de montagem com as inovações em aspectos tecnológicos e biotecnológicos, fetichizando o significado real do desenvolvimento agrícola, claramente de natureza econômica e política, secundarizando a real necessidade de abastecimento populacional, privilegiando as transações mercadológicas e financeiras. A industrialização do campo revelou a completa submissão do campo à lógica urbana e mercadológica de acumulação. Quanto mais se intensificou o capitalismo no campo, mais urbana se tornou a regulação da agropecuária, sua gestão, normatização, produção e exportação.

A inflexão do agrário para o urbano no Brasil se deu entre as décadas de 1960 e 1970, revelando o processo de industrialização do campo e o de aglomeração urbana, conforme ilustra o gráfico 1, de evolução da população. Esse duplo processo consolidou a dominação do
17. Ao resgatar tal relação, nota-se que desde sua origem, ao campo fora conferida certa primazia - a propriedade particular do solo, a produção rural, a ideia de ruralidade -, mantendo-se um caráter de necessidade e subordinação da cidade com relação ao campo, estabelecendo uma situação de antagonismo entre ambos. A dicotomia cidade-campo, rural-urbano (erroneamente associada à relação capital-interior aqui já observada), distinguia dois mundos completamente distintos, cada qual com sua cultura, organização socioeconômica, divisão do trabalho e estrutura produtiva. Dicotomia esta que passou a perder seu caráter de oposição e que não é de agora, mas desde o século XVII, as alterações nos modos de produção e de acumulação, associados ao crescimento do capital comercial e da existência do mercado em ascensão, já reconfiguravam as relações entre cidade e campo, substituindo a prioridade rural pela prioridade urbana.

18. LEFEBVRE, 1969.

19. GOTTDIENER, 1997, p. 231.

20. Ibid., p. 231.

21. OLIVEIRA, 2010. 


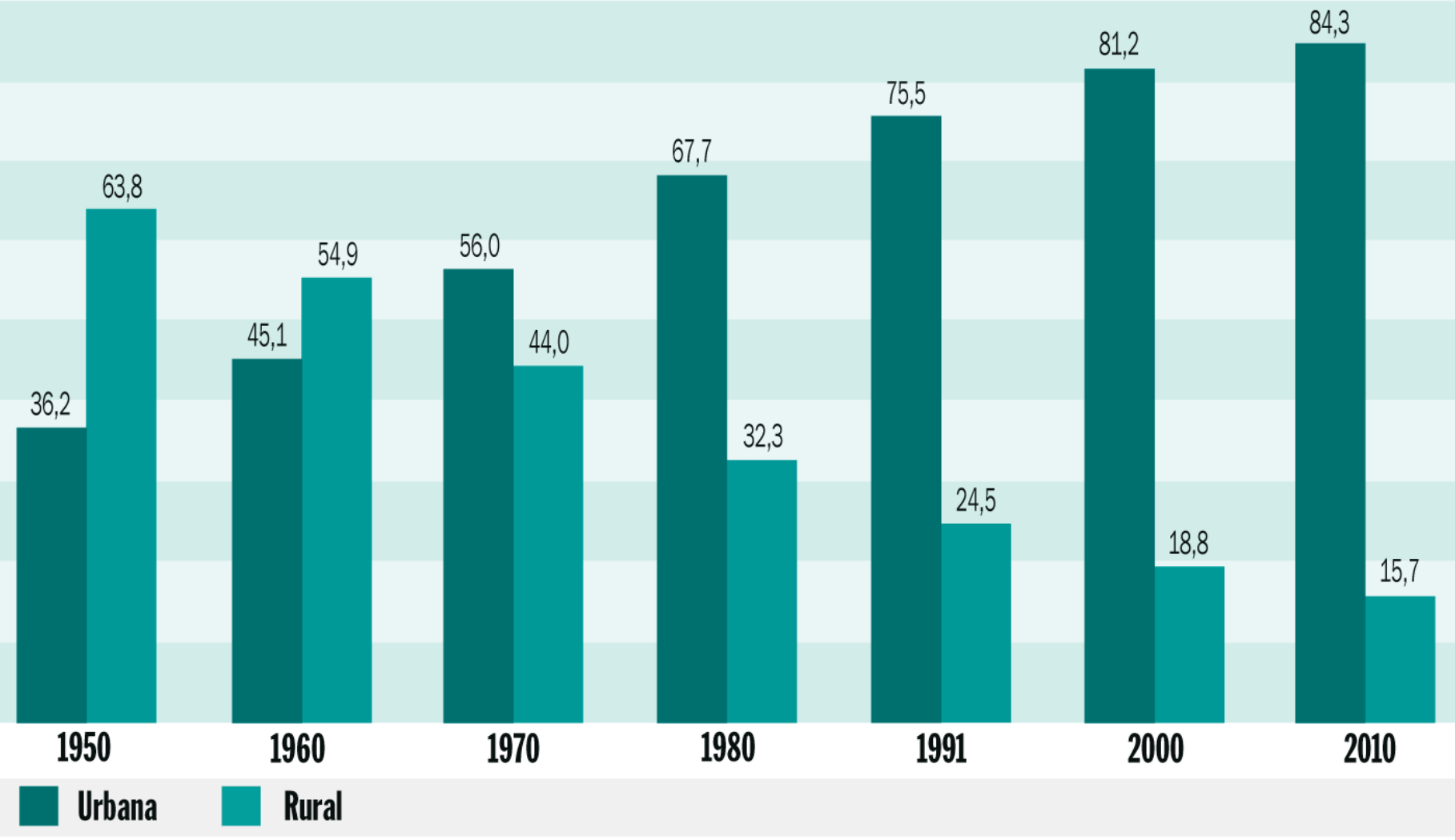

Gráfico 1 - Evolução da população por local de residência - Brasil (1950-2010).

Fonte: DEPARTAMENTO INTERSINDICAL DE ESTATÍSTICAE ESTUDOS SOCIOECONÔMICOS, Estatísticas do meio rural, p. 63, ed. 4. Dados informados pelo Instituto Brasileiro de Geografia e Estatística. Ministério do Desenvolvimento Agrário. Brasília, 2011. 
campo pela cidade através da expansão do mercado consumidor da indústria para o campo, qualificando este último como expansão do mercado consumidor industrial e também território de uma cadeia de produção voltada para a indústria.

A extensão das relações capitalistas à agricultura era uma pré-condição necessária do crescimento urbano. Sem ela, as fábricas da cidade não teriam desfrutado de uma força de trabalho com superabundância de trabalhadores, nem a força de trabalho teria sido reproduzida dentro das cidades na escala necessária para a expansão industrial ${ }^{22}$.

Muitas cidades reestruturaram suas áreas urbanas para incorporarem a atividade agroindustrial, tornando-a carro-chefe de suas economias. A tecnologia aplicada e tomada como base da produção agropecuária gerou uma gama enorme de gêneros industriais, dentre eles o de insumos e bens de capital. A inter-relação com a agricultura, assim como o desenvolvimento voltado à nova lógica de recomposição orgânica do setor com o desenvolvimento de gêneros industriais dinâmicos, tornou-se importante para a atração e criação de indústrias de produtos agropecuários e também de outros gêneros no território. Inicialmente, os insumos industriais agrícolas eram importados, até a instalação de empresas e indústrias do setor na região, apoiadas financeiramente pelo Estado $^{23}$. Suas indústrias firmaram suas bases econômicas na exploração do cultivo da terra, ou em atividades relacionadas a ela, a fim de lidar com o processo de mecanização e avanço tecnológico da atividade agrícola, aliando a produção com a finalidade de abastecer outros mercados e centros urbanos do país e do mundo. Com isso, atraíram outras modalidades de serviços e se abriram a novos mercados. Em 1960, o parque industrial da região de Ribeirão Preto já era o terceiro maior do estado, atrás apenas das regiões metropolitanas de São Paulo e Campinas, participando com 3,88\% do valor de produção estadual industrial. Assim, a urbanização regional se transformou no fenômeno que "melhor explicitou como agiriam os elementos de mudança do território regional, segundo particularidades e singularidades do processo geral de urbanização brasileira" ${ }^{24}$. Caracterizada por alguns autores como metrópole corporativa, incorporava no território reestruturações que supriam as necessidades da produção dos complexos agroindustriais, que superpunham novos fixos artificiais ${ }^{25}$ sobre a natureza do espaço.

Com a produção agrícola voltada para busca de consumo e exportação, a região de Ribeirão Preto atraiu também empresas de grande porte, como as de mecânica pesada de produção de maquinário para usinas, setores petroquímicos e siderúrgicos, capazes de modificar relações espaciais sobre o setor agrícola e terciário. Setores industriais, como metalúrgico e mecânico, se posicionaram nas últimas décadas ao setor agroindustrial, para fornecimento
22. Ibid., p. 231.

23. O marco inicial dessa política de substituição de importações e da segunda etapa é a instalação das primeiras indústrias multinacionais de tratores. A princípio, as empresas se associaram à modernização da atividade agrícola da região, porém conseguiram extrapolar o mercado regional e atingir não apenas outras regiões do país, mas também se articularem a nível global, participando do circuito superior da economia.

\section{ELIAS, 2003, p.26.}

25. SANTOS (2001) considera os elementos fixos como estradas, pontes, construções, barragens e estruturas construídas pelo homem. Juntamente com os fluxos (movimentos condicionados por ações), o autor define 0 espaço enquanto uma interação entre os fixos e os fluxos, um conjunto indissociável, solidário e ao mesmo contraditório de sistema de objetos e de sistema de ações que constrói e reconstrói o espaço. 
de maquinários e insumos agrícolas, como a Satal, Marchesan, Baldan e Zanini, instaladas em Sertãozinho. Inicialmente tais empresas atendiam às necessidades da produção agrícola regional. Posteriormente passaram a exportar sua produção para outras regiões e países. O grupo Zanini, controlado pela família Biagi, além de produzir maquinário para atividade agrícola, criou empresas autônomas que passaram a atuar no setor de montagem industrial. Tal grupo merece destaque por ter possuído o oligopólio do setor produtor de equipamentos para a indústria de açúcar e álcool, uma estrutura de mercado altamente concentrada; e por sua produção horizontal e vertical, responsabilizando-se pela formação de importantes centros industriais integrados à produção de equipamentos pesados na cidade de Sertãozinho.

Apesar da aglomeração e concentração de indústrias que se vinculavam à produção agrícola nos complexos, para que o Programa de Apoio à Agroindústria Açucareira pudesse ser executado era necessária a eliminação de pequenas usinas consideradas economicamente ineficientes, para acabar com a tendência de um maior preço do açúcar para fins de exportação (FERREIRA; ALVES, 2009). O número de usinas em São Paulo decresceu entre as décadas de 1940 e 1970, segundo dados do IAA, mas isso não significa que a produção decresceu no mesmo ritmo, muito menos que o território da produção tenha diminuído. Pelo contrário: com as fusões e aglutinações entre usinas, revelaram-se os processos de concentração da produção açucareira e o de concentração fundiária.

Assim como no setor sucroalcooleiro, a fusão entre grandes empresas, ou a fagocitose de pequenas indústrias também fora bastante recorrente no setor citrícola paulista que se desenvolveu na cidade de Matão, em 1964, com padrão norte-americano de produção.

Matão se configura como um lugar inserido na produção mundializada pela presença de grandes indústrias [citrícolas] que realizam suas produções conectadas ao circuito superior da economia, só completando seus circuitos espaciais da produção em territórios de outros países. $\mathrm{O}$ desenvolvimento das atividades associadas ao complexo agroindustrial deu grande alcance à cidade, ampliando sobremaneira os fixos e os fluxos de todas as naturezas, intensidades e direções, aumentando as atividades econômicas. A expansão do meio técnico-científico-informacional, o aumento das rugosidades, a construção da cidade corporativa, as novas relações cidade-campo e todas as demais variáveis e signos característicos do atual período histórico (...) estão presentes na cidade de Matão, que prospera com o desenvolvimento da agroindústria da laranja ${ }^{26}$.

Entretanto, a agroindústria citrícola ainda depende quase que exclusivamente da compra de matérias-primas de produtores autônomos - em sua 
maioria, pequenos e médios citricultores. Tal como a agroindústria canavieira, teve sua origem e desenvolvimento em um reflexo gerado em nível mundial: a abertura do mercado internacional decorrente de uma geada na Flórida, principal região citrícola do mundo no início dos anos 1960. A agroindústria citrícola se especializou, produzindo uma série de produtos para além do suco concentrado, inclusive álcool da laranja - combustível e industrial. Contudo, diferentemente da cana-de-açúcar, que promove um avanço tecnológico de indústrias metalúrgicas e mecânicas para a transformação e beneficiamento da produção industrial canavieira, a produção citrícola ainda depende muito de tecnologia norte-americana, indicando uma importação de modelo de produção, necessitando também a importação de maquinário e de tecnologias externas para produção na região. Com isso, a industrialização da cultura e sua indústria ganharam benefícios e foi solidificada a inserção do Brasil no mercado internacional, responsabilizando-se por mais de $50 \%$ do comércio mundial. Quatro grupos principais passaram a deter a quase totalidade da produção na região até os anos 1990: Cutrale, Citrosuco, Cargill e Frutesp. As indústrias citrícolas se instalaram nos municípios de Araraquara, Matão, Bebedouro, Colina e Itápolis, concentrando $65 \%$ da produção do setor no estado de São Paulo. As transformações ocorridas em Matão caracterizam as novas configurações de cidade, inserida em uma produção mundializada pela presença de grandes indústrias que realizam suas produções articuladas ao circuito superior da economia, completando seus círculos espaciais de produção em territórios de outros países. O desenvolvimento gerado nas cidades através dos complexos agroindustriais ampliou consideravelmente os fluxos e fixos de quaisquer naturezas.

Ainda que os processos de concentração da produção e de concentração fundiária tenham sido consequências diretas de intervenção estatal para estímulo imediato para inserção do país no mercado exterior, como medida de controle da expansão dos latifúndios, foi de imprescindível importância a criação do Sistema Nacional de Crédito Rural - SNCR -, em 1965. Tal política tinha como principal meta subsidiar a modernização da agricultura por meio do fornecimento de crédito, reunificando os interesses das classes dominantes e restabelecendo o poder regulador macroeconômico do Estado, através de uma política monetário-financeira expansionista (KARNOPP; OLIVEIRA, 2012). O SNCR foi uma medida bastante importante para a (re)inserção dos pequenos e médios agricultores no sistema, os quais corriam altos riscos por não terem condições, até então, de mecanizar sua produção e competir com os preços dos grandes latifúndios.

Até meados do século $X X$, a economia brasileira era hegemonizada pelo setor primário. O que se produzia no campo era vendido no exterior, o que atribuía ao Brasil o título de celeiro do mundo. Com a mudança para um modelo de substituição de importações, o centro dinâmico da economia passou a ser internalizado, ainda que a dinâmica externa fosse quem ditava e ainda dita o 
27. Ainteração entre ciência e técnica, sob a égide do mercado, produz objetos técnicos que são técnicos e informacionais, "já que, graças à extrema intencionalidade de sua produção e de sua localização, eles já surgem como informação" (SANTOS, 2006, p. 159), ao mesmo tempo em que a informação também constitui energia essencial para o funcionamento de tais objetos. Tanto tecnologia quanto ciência e informação passaram a estar inseridas na base da produção, da utilização e do funcionamento do espaço. Além disso, diferente do meio que o antecede, onde apenas as grandes cidades eram consideradas impérios da técnica e da artificialidade, o meio técnicocientífico-informacional passou a incluir mais países e regiões, sobretudo a esfera da produção agrícola.

28. SILVA, 1981, apud. ELIAS, 2003, p. 88. compasso da dança, e o Brasil poderia atingir o que PAULANI definiu como "maioridade econômica", de modo que seu crescimento econômico estaria compatibilizado com seu desenvolvimento enquanto nação. Com as crises mundiais a partir de 1970, a periferia do sistema capitalista apareceu durante a década como a demanda que absorveria a oferta de crédito e liquidez então existentes. Entretanto a alteração do sistema de acumulação mundial, endossada pela "ditadura dos credores", fez com que o país se encontrasse em um panorama econômico interno complicado pela alta da inflação - fruto da combinação entre crise do petróleo, dívida brasileira e processo de redemocratização do país.

Com os choques do petróleo nos anos 1970, o Estado brasileiro decidiu investir na produção de álcool combustível para sua frota veicular, de modo a minimizar o desequilíbrio gerado na balança comercial. Fora decidido, então, investir em tecnologias de extração e produção de petróleo nacional para consumo interno e principalmente no desenvolvimento de tecnologias voltadas à produção de cana-de-açúcar enquanto alternativa econômica viável ao petróleo. Tanto o Programa Nacional do Álcool (PNA - Proálcool) quanto o Programa Nacional de Melhoramento da Cana-de-Açúcar (PLANALSUCAR) foram importantes para o crescimento da produção sucroalcooleira no território nacional e para a espacialização produtiva na região.

O PLANALSUCAR, criado em 1971, foi um programa de investimento do IAA voltado para a área de pesquisa. Fomentava programas como o PMGCA (Programa de Melhoramento Genético da Cana-de-Açúcar), tendo como principal objetivo a obtenção de variedades de cana-de-açúcar melhoradas e adaptadas às diversas condições ambientais, atendendo às necessidades do setor sucroalcooleiro do país, permitindo a expansão do território canavieiro para além de limites impostos pela natureza (tipo de solo, umidade, frequência de chuvas, $\mathrm{pH}$ do solo, dentre outros) e o fortalecimento da monocultura. Em 1973, foi criada a Empresa Brasileira de Pesquisa Agropecuária (EMBRAPA), que, vinculada ao Ministério da Agricultura, Pecuária e Abastecimento (MAPA), tinha o intuito de desenvolver, em conjunto com o Sistema Nacional de Pesquisa Agropecuária (SNPA), pesquisas voltadas para a produção agropecuária, produção de insumos agrícolas, fertilizantes e adubos, incorporando terras degradadas aos sistemas produtivos, aumentando a produtividade da terra e a rentabilidade da produção de alimentos e produtos agrícolas $^{27}$.

A biotecnologia passou a se caracterizar como uma das tecnologias que mais contribuíram para a organização do território. Ela gerou transformações deveras aceleradas no setor, alinhando-se ainda mais às lógicas de produção industrial, produzindo seres para o capital e, segundo ELIAS (2003), reproduzindo "artificialmente a própria natureza" ${ }^{28}$, subordinando os próprios ciclos naturais de produção de recursos, adequando-os a padrões de produção e consumo, como demais mercadorias de base industrial. A engenharia 
genética possibilitou o melhoramento de espécies e da produção de sementes híbridas, sua resistência a pestes e adaptação a climas e solos adversos e diminuição de ciclos produtivos, o que viabilizou uma maior quantidade de safras, aumentando a produtividade sem ampliar as extensões de terra para cultivo ${ }^{29}$, revelando uma reestruturação no processo de produção agrícola e uma nova modalidade de exploração ao nível microscópico, através de patenteamento e licenciamento de materiais genéticos, plasmas de sementes e toda a sorte de produtos relacionados à reprodução do capital no campo, dada a ênfase nos direitos de propriedade intelectual de grandes organizações (como os Acordos Trips) $)^{30}$.

A produção tecnológica da região de Ribeirão Preto passou a estar associada às principais culturas agrícolas, e o surgimento de um dos poucos polos de pesquisa e produção de tecnologia do Brasil em São Carlos ${ }^{31}$ aumentou o número de indústrias high tech competitivas, inclusive em mercados externos. São Carlos e Jaboticabal são denominadas cidades-sede de instituições de pesquisa de aprimoramento e inovação técnica do setor, como a EMBRAPA e as universidades públicas em São Carlos, e a Universidade Estadual Paulista "Júlio de Mesquita Filho" (UNESP) e a Faculdade de Ciências Agrárias e Veterinárias (FCAV), em Jaboticabal. Destaca-se também Sertãozinho como cidade da primeira sede do centro brasileiro privado de inseminação artificial pecuária, em 1978.

\begin{abstract}
A extensão das relações capitalistas à agricultura era uma pré-condição necessária do crescimento urbano. Sem ela, as fábricas da cidade não teriam desfrutado de uma força de trabalho com superabundância de trabalhadores, nem a força de trabalho teria sido reproduzida dentro das cidades na escala necessária para a expansão industrial $\left.\right|^{32}$.
\end{abstract}

A pesquisa científica em prol do desenvolvimento de tecnologias tornou-se essencial e aproximou a esfera acadêmica aos complexos agroindustriais. Na lógica de produção e consumo globalizados, a tecnologia se constituiu grande vetor de crescimento econômico, justificando a localização e produção científica de campi como os da Universidade Federal de São Carlos (UFSCar), da Universidade de São Paulo (USP), e da UNESP na região de Ribeirão Preto, além dos campi de centros universitários particulares. Do ponto de vista territorial, a localização ideal dos estabelecimentos de tecnologia de ponta, segundo ELIAS (2003), situa-se nas proximidades de centros universitários e de pesquisa ${ }^{33}$.

Além do investimento em tecnologia fornecido através do PLANALSUCAR, o Estado brasileiro investiu também nas empresas articuladas aos complexos agroindustriais. Deste modo, a Empresa Brasileira de Assistência Técnica e Extensão Rural (EMBRATER) foi um dos instrumentos de caráter executivo que o Estado brasileiro criou para desenvolver a produção
29. Grandes holdings que têm monopolizado vários setores industriais associados à modernização da agropecuária foram os patrocinadores por trás do milagre agrícola, atentando-se ao interesse em espécies de polinização cruzada, de grãos que não se reproduzem quando replantados, tornando os produtores agrícolas dependentes da compra anual de sementes. Assim, tanto a especiação em larga escala quanto os híbridos (transgênicos) se constituem verdadeiros ícones da globalização, ou do rebaixamento da produção de subsistência humana para um mercado complexificado.

\section{HARVEY, 2011.}

31. Instituições de pesquisa de conteúdo tecnológico voltados para a produção material para além da aplicação na agroindústria, mas em diversos outros setores, produtos e serviços.

32. ELIAS, 2003, p.93. 
33. A autora concorda com o pensamento de Henrique Rattner de que o avanço das novas tecnologias, além das alterações em suas cadeias de produção, alteram também padrões locacionais das plantas industriais, gerando decadência de algumas regiões, "abrigando indústrias tradicionais de equipamento obsoleto e a rápida expansão de outras que abrigam estabelecimentos com tecnologia de ponta e pesquisa e desenvolvimento intensivos" (ELIAS, 2003).

34. Foi extinta na década de 1990 e suas atribuições repassadas as Empresas de Assistência Técnica e Extensão Rural (EMATER).

35. GASPARETTO JUNIOR, A. Proálcool. Disponível e $\mathrm{m}$

<http://www.infoescola.com/combustiveis/proalcool/> Acesso em: 11/06/2014.

36. PECQUEUR, B. Le développement local. Ed. 2. Paris: Syros, 2000. agropecuária nacional, passando os serviços de assistência técnica e extensão rural ao âmbito governamental sob a forma de empresas públicas vinculadas ao Ministério da Agricultura e às Secretarias de Agricultura. Criada em 1974 , a empresa tinha como principais objetivos o credenciamento, supervisão e fiscalização das empresas privadas que prestavam assistência técnica aos agricultores em todo o Brasil, além de fornecer financiamentos, assistência técnica e serviço de extensão rural a pequenos produtores agrícolas e a agricultores familiares ${ }^{34}$.

Por conta de fatores externos, como a queda do preço do açúcar, e pelo fato de o Brasil ter perdido o mercado norte-americano, em 1974, as pretensões brasileiras de grande exportador de açúcar foram dificultadas. Para aliviar as perdas enfrentadas pelo subsetor da indústria sucroalcooleira, o Estado, pressionado por grupos usineiros e empresas fabricantes de insumos e tecnologias do complexo agroindustrial e com o apoio e integração da indústria automobilística, fundou o Proálcool. Criado em 1975, pelos engenheiros Lamartine Navarro Júnior e Cícero Junqueira Franco, em parceria com o empresário Maurílio Biagi (grande empresário proprietário de terras e de usinas na região de Ribeirão Preto), tinha como principal meta intensificar a produção de álcool (etanol) no país, para suprir a demanda energética enquanto alternativa ao petróleo ${ }^{35}$. Para isso, oferecia vários incentivos fiscais e empréstimos com juros abaixo da taxa de mercado para os produtores de cana-deaçúcar e para as indústrias automobilísticas que viessem a produzir carros movidos a álcool. Criava-se, então, um novo mercado e uma nova demanda, financiados e apoiados pelo governo para aliviar as perdas enfrentadas pelo setor.

Na primeira fase do Proálcool, a meta era a produção de 3 bilhões de litros de álcool até 1980. Para a aplicação dos recursos e investimentos federais, o Estado utilizou-se fundamentalmente da organização territorial da produção através dos complexos agroindustriais sucroalcooleiros, de modo que grande parte dos investimentos contemplou a região do estado de São Paulo, em virtude da rede bastante consolidada devido à produção cafeeira do início do século XX (FERREIRA e ALVES, 2009). Contudo, dentro do próprio estado paulista, a implantação de destilarias foi concentrada nas tradicionais áreas e complexos agroindustriais de Piracicaba, região de Ribeirão Preto, Araraquara, Jaú e Vale do Paranapanema, conforme indicado na figura 7.

Segundo Bernard Pecqueur, o território pode promover sua dinâmica a partir da aglomeração, da especialização e da especificação ${ }^{36}$. Tais modalidades de dinâmica não são lineares, pois estão relacionadas com a história de cada região, de suas próprias dinâmicas em outras esferas e setores e de fenômenos globais. Na aglomeração, o ter- 


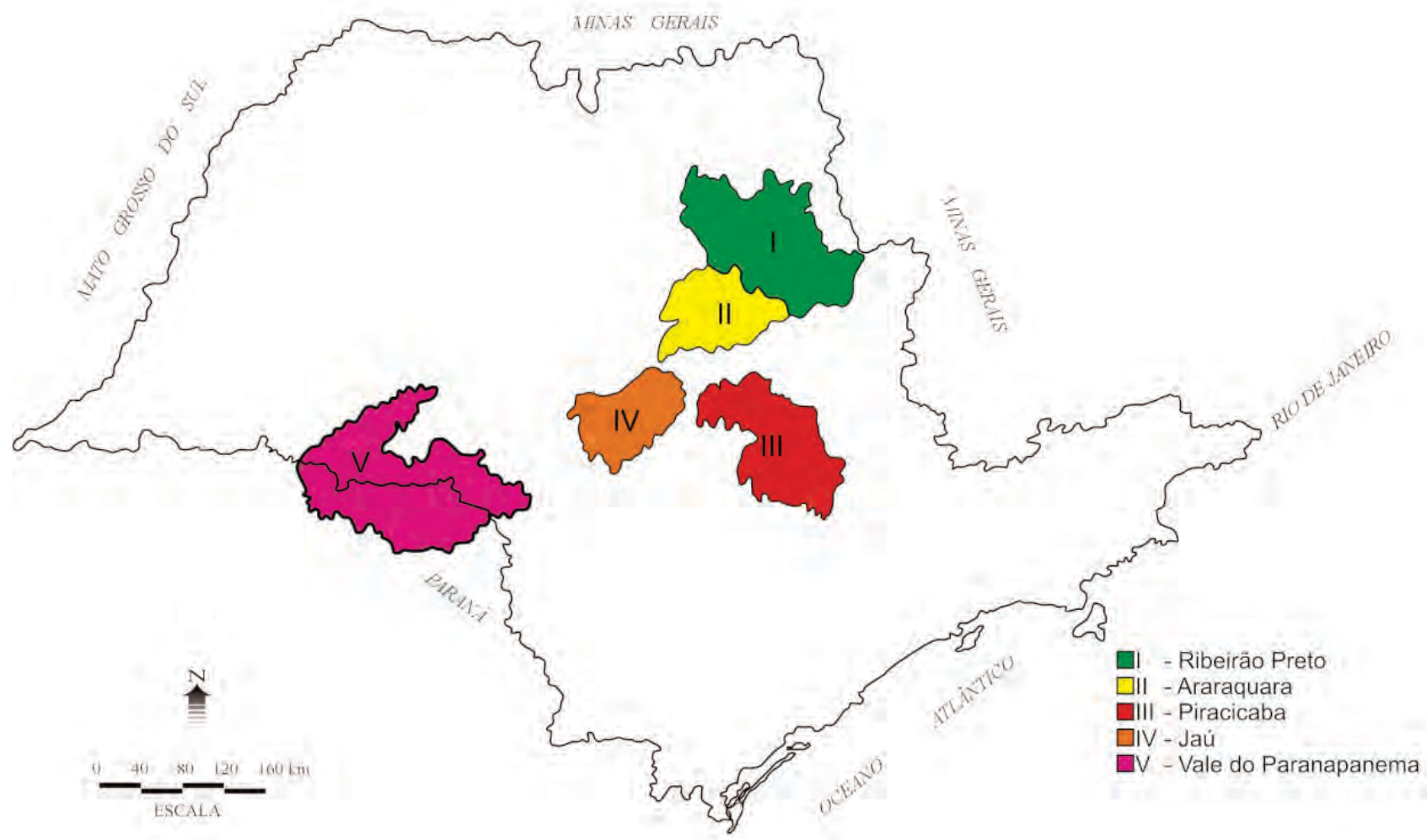

Figura 7 - As tradicionais áreas canavieiras do estado de São Paulo-Brasil (1950-2010).

Elaborado a partir de dados do PLANALSUCAR.

Fonte: LOPES, M. 0 complexo agroindustrial canavieiro e a territorialização no estado de São Paulo. In: Anais do XVI Encontro Nacional dos Geógrafos. ISBN 978-85-99907-02-3. Porto Alegre, 2010. 
37. Segundo PIRES (2006), consiste em um recorte geográfico - incluindo parte de um município ou um conjunto de vários outros (além de características naturais) - agrupando conjuntos de micro, pequenas e médias empresas especializadas cooperando em uma mesma atividade e/ou atividades complementares em conjunto com outros atores públicos e privados e com sinais de identidade coletiva, mantendo ou convergindo em um desenvolvimento local, especializando investimentos dos atores do arranjo e de seu entorno, tendo como pontos comuns à troca de informações, de capitais, o apoio institucional, governo cooperativo e uma cultura comum.

38. Tal corrente desenvolvimentista no Brasil fora inspirada em um keynesianismo, a favor da industrialização e da consolidação do desenvolvimento capitalista através de um planejamento estatal, contrapondo-se ao neoliberalismo já atuante na década de 1960 . ritório se desenvolve através da acumulação de atividades e serviços, favorecidos por políticas de isenção fiscal, planejamento territorial e infraestrutura para recebimento, concentração e instalação das atividades. A expansão do consumo produtivo da agropecuária científica se deu através de investimentos estatais nos complexos agroindustriais, estabelecendo-se relações de produção em conjunto com outras indústrias para fabricação de bens de consumo produtivo - sejam as fornecedoras de insumos agrícolas e sementes, sejam as transformadoras e beneficiadoras destinadas à exportação. Isso atraiu e aglomerou nos centros urbanos uma população específica de mão-de-obra qualificada que passou a gerar necessidades de serviços e consumo que atraíram outras formas de indústria e setores de serviços para a região, de modo que a própria cidade e cidades vizinhas se reorganizaram para suprir as demandas por insumos intelectuais e materiais. Tal crescimento populacional significativo e o alto poder aquisitivo da população propiciaram o surgimento de inúmeras casas de comércio e de estabelecimentos que oferecem serviços especializados mais modernos, antes restritos às principais capitais do país, determinando um novo modelo e uma nova configuração regional através de arranjos produtivos ${ }^{37}$, revelandose pontes entre a economia política da urbanização das cidades e organização espacial resultante da realização das atividades econômicas desenvolvidas na região. Em Ribeirão Preto, a aglomeração de serviços serviu de entreposto em tomadas de decisão ou fornecimento de serviços entre as cidades da região e a metrópole paulista.

$\mathrm{Na}$ especialização, certa atividade econômica ou industrial reorganiza o território, de modo a compor um complexo, visando à acumulação de pesquisas e saberes sobre uma atividade específica, ou seja, na capacidade de setores de se articularem e se relacionarem de maneira específica, social, política, econômica e espacialmente. Tal processo está associado a um desenvolvimento em nível nacional, gerido e articulado pelo Estado, que organiza sua produção de acordo com as vocações de regiões e territórios, direcionando recursos e benefícios para regiões específicas de acordo com a importância e necessidade de sua produção, assim como incentivando empresas nacionais para manter a economia aquecida ${ }^{38}$. No caso da região de Ribeirão Preto, destaca-se o setor agroindustrial e a instalação de um forte complexo agroindustrial voltado para a produção de açúcar e álcool. Deste modo, gerou-se uma especificidade: a produção passou a ser elaborada por meio de uma coordenação entre os agentes econômicos públicos e pri- 
vados, tendo como foco a monocultura, ou a produção de um único bem, livre de concorrências e inerente apenas a um processo de produção, o que atribui aos produtos um caráter de específicos, produzidos em condições únicas. A expansão dos complexos agroindustriais, portanto, gerou repercussão tanto na esfera técnica da produção como profundos impactos nas relações sociais de produção, causando uma nova divisão social e territorial do trabalho, caracterizando assim uma nova forma econômica e social da agropecuária, acompanhando a unificação da economia através do capital industrial e financeiro. O crescimento urbano e o avanço das telecomunicações e transportes, bem como a espacialização da produção na região de Ribeirão Preto intensificaram as trocas, aumentando as possibilidades de fluxos internos à região e ensejando integração com o território nacional, estreitando, de início, relações com a capital paulista e com o porto de Santos.

A estruturação em rede se configurou, deste modo, em plataforma bastante atrativa ao contemplar necessidades específicas e essenciais do capital financeiro, como a flexibilidade e a volatilidade. Aparentemente ordenada, a organização geral espaço-temporal se mostrou racional e homogênea e começou a ser preenchida por uma multiplicidade de objetos, ações, atividades, pessoas. Toda a rede de circulação composta por ferrovias e rodovias foi sobreposta, a partir da segunda metade do século XX, por redes de telefonia, de tráfego aéreo e de telecomunicações ${ }^{39}$. A reestruturação econômica conferiu à questão regional um maior destaque, uma vez que o processo de globalização da economia mundial fora acompanhado por uma fragmentação politica em interesses localizados, afetando diretamente as relações Estado-região. As longas distâncias, reduzidas virtualmente pelas inovações tecnológicas, geraram a falsa impressão de que o território fora homogeneizado (uma vez que as informações passaram a chegar com maior velocidade a quaisquer pontos do espaço), quando, na verdade, ocorre justamente o oposto. À localização geográfica fora atribuído um valor estratégico mais seletivo. As vantagens locais foram destacadas e fortalecidas, de modo que cidades e regiões passaram a ser diferenciadas pelo que poderiam oferecer - recursos e belezas naturais, redes de transporte, disponibilidade de mão-de-obra, infraestruturas e outros atrativos. Para além de suas especificidades regionais, a localização geográfica de Ribeirão Preto é bastante relevante, dadas as distâncias até a capital paulista, à região metropolitana de Campinas, Goiânia e Belo Horizonte; e as relações espaciais da cidade (no que diz respeito
39. O desenvolvimento de redes técnicas e inovações tecnológicas surgiram em resposta a demandas socioeconômicas pontuais, distribuídas por toda a extensão do território. As ferrovias no fim do século XIX, e a teleinformática no $X X$, todas essas tecnologias reduziram o lapso de tempo entre um lugar e outro, aproximando-os virtualmente, inclusive gerando novas adjetivações para os conceitos de região e território. Tais inovações são fundamentais para a história do capitalismo mundial, modificando as relações de produção e aumentando a velocidade dos fluxos humanos, de bens, informacionais e de capital. 


\section{ARROYO, 2006}

41. Ela extrapola a simples noção de transporte de mercadorias e bens de consumo, perpassando também mãode-obra, consumidores, técnicas, capitais, ideias, informações, armas, indústrias e formas sociais, ultrapassando os objetivos estritamente econômicos, constituindo-se também enquanto em infraestrutura regulada pelo Estado, determinando seu caráter político. As estratégias e medidas políticas facilitam escoamentos e a circulação de modo geral, estabelecendo uma rede de relações entre cidades, de modo que tais relações se tornam constitutivas do território e determinantes em sua personalidade política, tal como sua posição geográfica, essenciais para localização da região no mercado globalizado e suas estratégias de captação de recursos ou atração de capital. ao consumo, à divisão social do trabalho e às funções desempenhadas).

A rede viária da região de Ribeirão Preto, bastante consolidada, permitiu articular as cidades da região, entre si e com outras regiões, através de importantes eixos viários como a rodovia Anhanguera (SP-330), que faz a ligação com Campinas, São Paulo, São Joaquim da Barra, Triângulo Mineiro e Brasília; a Cândido Portinari (SP-334), que a liga Franca e Minas Gerais; a Atílio Balbo/Armando Sales de Oliveira (SP 322), que une Ribeirão Preto, Sertãozinho e Bebedouro; a Antônio Machado Sant'Anna (SP 255), que liga Ribeirão Preto a Araraquara e à rodovia Washington Luís; e a Abraão Assed (SP 333), que articula Ribeirão Preto, Serrana, Jaboticabal, a rodovia Washington Luís e a cidade de Marília. Arelação entre as cidades e a circulação se anunciou na convergência ao fato de as cidades terem capacidade de criar condições de fluidez territorial, tornando-se pontos de confluência de diversos circuitos produtivos. Tais atributos, não mais exclusivos de metrópoles ou grandes centros urbanos, passaram a ser reconhecidos em cidades de menor escala, conformando um processo de diferenciação espacial e um caráter concentrador e hierárquico que legitimam o desenvolvimento desigual ${ }^{40}$.

Conforme visto anteriormente, a região de Ribeirão Preto possui um sistema de transportes e comunicação entre cidades bastante consolidado e que contribui para o escoamento da produção, as trocas de informações entre elas e o estreitamento das relações socioeconômicas. Ao mesmo tempo em que homogeneíza os territórios, a circulação possui um caráter de diferenciação dos gêneros de vida ${ }^{41}$. Com a especialização e espacialização da produção, como nos complexos agroindustriais na região de Ribeirão Preto, uma série de atividades foi criada, não apenas relacionada direta ou indiretamente com a produção propriamente dita, mas também para demais formas e necessidades de consumo. O mesmo ocorreu com a geração de atividades voltadas para a circulação - empresas especializadas no transporte de cargas e de pessoas, na transmissão de informações e comunicações.

Ainda em contraponto com a homogeneização do território, a circulação estabelece um nível hierárquico entre lugares em função das estratégias definidas por agentes públicos e privados, uma vez que não é todo o território do lugar, da cidade, que interessa a empresas e ao capital. Deste modo, reconfiguram-se movimentos, completamente relacionados com a produtividade espacial - assumida muitas vezes 
por cidades de menor porte que as metrópoles, ao adentrarem na bataIha da competitividade, revelando o caráter político e de exercício de poder para além de questões econômicas. A circulação é o que articula as instâncias produtivas da divisão territorial do trabalho, sendo os fluxos os reguladores do processo produtivo e a realização do capital, redefinindo em grande parte o território
42. ARROYO cita Milton Santos ao afirmar que o mundo se encontra articulado em subespaços articulados dentro de uma lógica global. Assim, a internacionalização dos circuitos expressa o caráter geográfico através de redes de produção transnacionais (ARROYO in SPOSITO, 2006). 



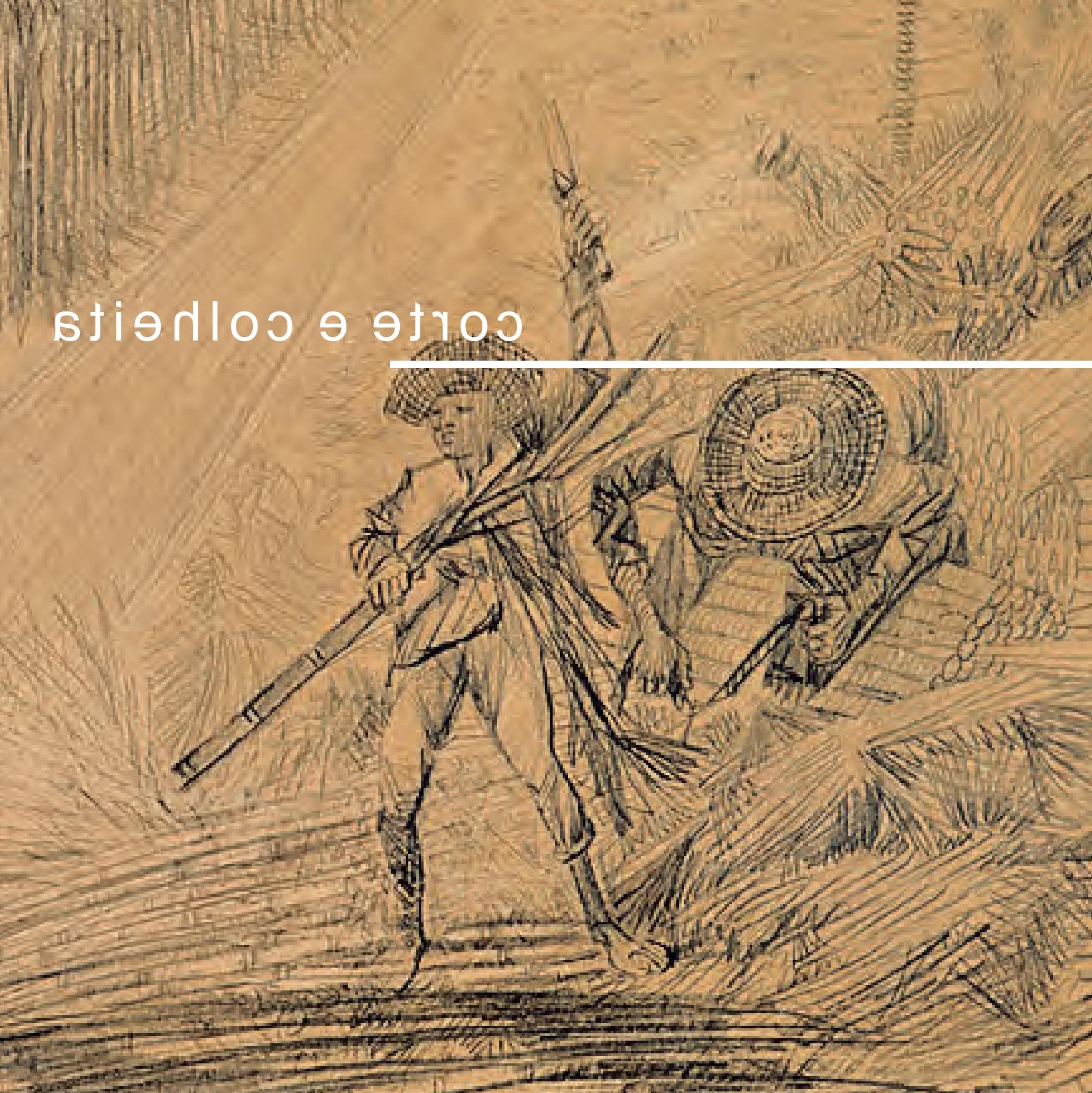




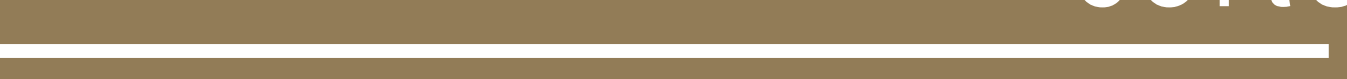

corte

e colneita

\section{a} \\ Heita}


ESPECIFICIDADES NA REGIÃO DE RIBEIRÃO PRETO

43. EGLER, C. Questão regional e gestão do território no Brasil. In: CASTRO; CORRÊA; GOMES. Geografia conceitos e tema. Rio de Janeiro: Bertrand Brasil, 2000.
O estado paulista apresentou um dos maiores desenvolvimentos econômicos do país a partir dos anos 1980, em virtude da modernização de sua agropecuária, concentrando boa parte de todos os recursos técnico-científicos e financeiros para o setor do país, e também o maior número de indústrias diretamente atreladas à produção agrícola. O protagonismo da região Centro-Sul sinaliza a reestruturação da produção no território, em virtude da infraestrutura, acesso a serviços, investimentos estatais e uma organização regional focada em tal setor produtivo enquanto um excelente negócio.

Egler (2000) apontou uma forte relação entre economias de aglomeração (complexos industriais), de urbanização e o surgimento de novas indústrias, de modo que a atividade industrial nas regiões especializadas se desenvolve não pelos insumos e infraestrutura que as cidades oferecem, mas pelo desenvolvimento de uma divisão social do trabalho no interior do sistema produtivo, gerando desigualdades territoriais $^{43}$, ou seja, os investimentos públicos não são distribuídos de maneira uniforme pelo território, mas algumas regiões do território são mais beneficiadas que outras, a exemplo do interior de São Paulo e do Nordeste, ambas produtoras de cana-de-açúcar desde os anos 1970. 
Ainda que a produção açucareira brasileira tenha sua origem há séculos no Nordeste do país (que possui participação ativa em parcela considerável no total de produção nacional sucroalcooleira ${ }^{44}$ ), a região Centro-Sul se tornou a mais produtiva, conforme pode ser visualizado nas tabelas 1 e 2 de exportação de açúcar e álcool. Os investimentos privilegiaram a região Sudeste em detrimento das demais, devido a pressões externas e a interesses de uma elite nacional e de grandes empresas (sobretudo as produtoras de equipamentos para o setor sucroalcooleiro, articuladas a seus congêneres no mercado internacional, que impulsionavam determinadas ações do Estado), cujas sedes e matrizes produtivas ali estavam instaladas.

Aos 1980, a região de Ribeirão Preto era composta por 80 municípios, conforme a figura 8. Se no início do século XIX os atributos físicos ainda eram os fatores que delimitavam e conformavam uma região, conforme visto anteriormente na figura 1, destacando-se a localização de Ribeirão Preto em solo de terra roxa, a divisão administrativa estatal tornou-se mais precisa e voltada a interesses mais específicos por parte do Estado, dadas as relações socioeconômicas entre os municípios e suas atividades produtivas mais específicas.

É importante destacar que as atividades do complexo agroindustrial possuem suas próprias territorialidades, criando suas próprias redes de cidades. Ao se analisar o setor pecuário, no qual a região de Ribeirão Preto também tem se destacado pelo complexo de indústrias de criação, abate e processamento de produtos de origem animal, é possível notar que o mesmo se concentra nos municípios de Ribeirão Preto e Barretos, assim como a produção de laticínios acaba se concentrando nos municípios de São Carlos, Descalvado, Franca, Ituverava, Pitangueiras e Ibitinga, juntamente com a instalação de plantas industriais associadas a empresas globais em algumas dessas cidades (como fábricas da Nestlé). O mesmo é visto na produção de alimentos em conserva (conformando uma territorialidade que inclui Ribeirão Preto, Taquaritinga e São Carlos); na de biscoitos e doces (fortemente concentrada em Ribeirão Preto); na de bebidas (em Ribeirão Preto e Patrocínio Paulista, onde se localizam empresas como Antártica e Coca-Cola); na de calçados (subprodução da pecuária polarizada na cidade de Franca, que também abriga indústrias de borracha, curtumes e indústrias de plástico, todas voltadas para a produção calçadista). As indústrias de papel e celulose também definem seu território produtivo concentrando-se no município de Luiz Antônio. A região também se
44. É importante ressaltar que a produção brasileira de açúcar tem sua origem em terras nordestinas durante 0 ciclo da cana-de-açúcar nos séculos XVI e XVII. Já a produção de açúcar no território paulista só se efetivou posteriormente no século XVIII, concentrada na região denominada Quadrilátero do Açúcar, formado pelas cidades de Sorocaba, Jundiaí e Campinas, sendo sucedida a partir da década de 1860 pela cultura do café. Somente após a crise do café no século XX que a região retomou e expandiu a monocultura canavieira (FERREIRA e ALVES, 2009), consolidando-a enquanto uma das principais bases da economia agrícola do estado. Esse resgate é importante para se compreender que a produção açucareira brasileira possui dinâmica, temporalidade e uma origem geográfica que não está localizada na região que hoje corresponde a uma das mais produtivas do país. 


\begin{tabular}{|c|c|c|c|c|c|}
\hline \multirow{2}{*}{ Estados } & \multirow[b]{2}{*}{$2010 / 2011$} & \multirow[b]{2}{*}{ 2011/2012 } & \multicolumn{3}{|c|}{$\mathrm{Na}$ atual safra, valoros atualizadios ato 5/2015 } \\
\hline & & & $2012 / 2013$ & $2013 / 2014$ & $2014 / 2015$ \\
\hline SĀO PAULO & 18.264 .427 & 15.026 .669 & 16.337 .433 & 17.702 .997 & 1.822 .025 \\
\hline PARANÁ & 2.721 .486 & 2755.990 & 2.782 .530 & 2.623 .616 & 245.321 \\
\hline MINAS GERAIS & 1779.368 & 2.373 .199 & 2.639 .601 & 2557624 & 221.272 \\
\hline ALAGOAS & $1,877,355$ & 1.896 .855 & $1,719,511$ & $1.319,065$ & 299,648 \\
\hline MATO GROSSO DO SUL & $1,030.736$ & $1,293,809$ & 1.514 .941 & 1.109 .908 & 54.329 \\
\hline Golás & 456.881 & 584.830 & 929.368 & 727.742 & 50.871 \\
\hline PERNAMBUCO & 849.353 & 754.447 & 598.019 & 314.060 & 48.662 \\
\hline PARAIBA & 86.104 & 125.571 & 113.644 & 16.087 & 2.320 \\
\hline SANTA CATARINA & 328.837 & 0 & 12 & 4 & 0 \\
\hline ESPIRITO SANTO & 39.432 & 60.580 & 83.767 & 68.571 & 0 \\
\hline SERGIPE & 27.834 & 25.564 & 36.865 & 15.868 & 2.587 \\
\hline RIO GRANDE DO NORTE & 33.410 & 23.897 & 8.689 & 5.381 & 387 \\
\hline MATO GROSSO & 16.642 & 21.685 & 18.540 & 9.787 & 400 \\
\hline RIO DE JANEIRO & 1.496 & 2.540 & 69 & 457 & 0 \\
\hline RIO GRANDE DO SUL & 27 & 0 & 4.080 & 140 & 0 \\
\hline MARANHĀO & 0 & 0 & 2744 & 0 & 0 \\
\hline RONDÔNIA & 329 & 63 & 0 & 63 & 15 \\
\hline ACRE & 37 & 0 & 0 & 17 & 0 \\
\hline PARÁ & 8 & 0 & 0 & 0 & 0 \\
\hline CEARA & 1 & 0 & 0 & 0 & 0 \\
\hline \multicolumn{6}{|l|}{ DISTRITO FEDERAL } \\
\hline CENTRO-SUL & 24.639 .751 & 22.119 .305 & 24.312 .258 & 24.959 .453 & 2.403 .751 \\
\hline NORTE-NORDESTE & 2.874 .701 & 2.826 .396 & 2.479 .520 & 1.670 .540 & 353.620 \\
\hline TOTAL. & 27.514 .452 & 24.945 .701 & 26.791 .778 & 26.629 .993 & 2.757 .371 \\
\hline
\end{tabular}

Tabela 1 - Exportação anual de açúcar por estado brasileiro (toneladas) - 2010/2011-2014/2015.

Fonte: Elaborada pela UNICA a partir de dados disponibilizados pela Secretaria de Comércio Exterior -

SECEX. Disponível em: $<h t t p: / / w w w . u n i c a d a t a . c o m \cdot b r />$

Exportação anual de etanol por estado brasileiro (mil litros)

\begin{tabular}{|c|c|c|c|c|c|}
\hline \multirow[b]{2}{*}{ Estados } & \multirow[b]{2}{*}{$2010 / 2011$} & \multirow[b]{2}{*}{$2011 / 2012$} & \multicolumn{3}{|c|}{ Na safra atual, valores atualizados ate $5 / 201 d$} \\
\hline & & & $2012 / 2013$ & 2013/2014 & $2014 / 2015$ \\
\hline SÃO PAULO & 1.245 .319 & 1.369 .467 & 2.885 .880 & 2.271 .280 & 261.378 \\
\hline PARANÁ & 371.858 & 235.862 & 183.100 & 143.049 & 0 \\
\hline MINAS GERAIS & 130,061 & 93.644 & 105.257 & 66.449 & 15.156 \\
\hline ALAGOAS & 132.719 & 142.866 & 92,462 & 23.248 & o \\
\hline GOIÁS & 14.185 & 20 & 49.348 & 30.508 & 92 \\
\hline MATO GROSSO DO SUL & 474 & 9.855 & 58.165 & 16.824 & 0 \\
\hline PARAIBA & 5.226 & 30.673 & 24.276 & 9.492 & 0 \\
\hline MATO GROSSO & 0 & 0 & 44.763 & 23.509 & 0 \\
\hline TOCANTINS & 0 & 0 & 34.413 & 9.801 & 0 \\
\hline RIO DE JANEIRO & 0 & 74 & 49 & 11.113 & 0 \\
\hline ESPIRITO SANTO & 5.696 & 0 & 4.932 & 0 & 0 \\
\hline RIO GRANDE DO NORTE & 0 & 4.524 & 0 & 0 & 0 \\
\hline PERNAMBUCO & 0 & 0 & 153 & 229 & 51 \\
\hline RIO GRANDE DO SUL & 1 & 1 & 1 & 137 & 32 \\
\hline SANTA CATARINA & 81 & 4 & 2 & 0 & 0 \\
\hline AMAZONAS & 0 & 0 & 0 & 0 & 0 \\
\hline CENTRO-SUL & 1.767 .675 & 1.713 .964 & 3.331 .495 & 2.562 .870 & 276.658 \\
\hline NORTE-NORDESTE & 137.945 & 178.063 & 151.304 & 42.770 & 51 \\
\hline TOTAL & 1.905 .621 & 1.892 .026 & 3.482 .800 & 2.605 .640 & 276.708 \\
\hline
\end{tabular}

Tabela 2 - Exportação anual de etanol por estado brasileiro (mil litros) - 2010/2011-2014/2015.

Fonte: Elaborada pela UNICA a partir de dados disponibilizados pela Secretaria de Comércio Exterior -

SECEX. Disponível em: $<h t t p: / / w w w . u n i c a d a t a . c o m . b r />$ 


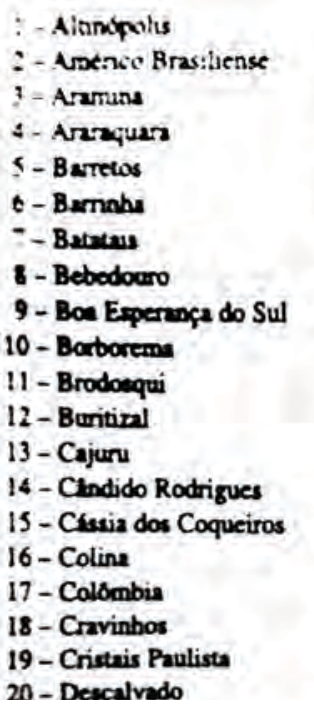

21- Dobrada
22 - Dourado
23 - Dumont
24 - Fernando Prestes
25 - Franca
26 - Guaira
27 - Guará
28 - Guariba
29 - Ibaté
30 - Ibitinga
31 - Igarapava
32 - Ipua
33 - Itápolis
34 - Itirapua
35 - Ituverava
36 - Jaborandi
37 - Jaboticabal
38 - Jardinopolis
39 - Jeriquara
40 - Luis AntAnio

41 - Matăo

42-Miguelópolis

43 - Monte Alto

44 - Monte Azul Paulista

45-Morro Agudo

46 - Nova Europa

47 - Nuporanga

48 - Orlândia

49 - Patrocínio Paulista

50-Pedregulho

S1 - Pirangi

52 - Pitangueiros

53 - Pontal

54 - Pradópolis

55 - Restinga

56 - Ribeirảo Bonito

57 - Ribeirão Corrente

58 - Ribeiråo Preto

59 - Rifaína

60)- Rincăo

\section{1 -Sales Oliveira \\ 62 - Santa Ernestina \\ 63 - Santa Lúcia}

64 - Santa Rita do Passo Quatro

65 - Santa Rosa do Viterbo

66 - Santo Antônio da Alegria

67 - Săo Carlos

68 - São João da Barra

69 - São José da Bela Vista

70 - Săo Simão

71 - Serra Azul

72 - Serrana

73 - Sertäozinho

74 - Tabatinga

75 - Taiaçu

76-Tauúva

77 - Taquaritinga

78 - Terra Roxa

79 - Viradouro

80 - Vista Alegre do Alto

Figura 8 - Região administrativa de Ribeirão Preto, segundo divisão municipal, 1983.

Fonte: Perfil Municipal, SP, vol. 5, 1983, Seade. Extraído de: ELIAS, Denise. Globalização e agricultura: A região de Ribeirão Preto - SP, p. 29. Universidade de São Paulo, EdUSP. São Paulo: 2003.
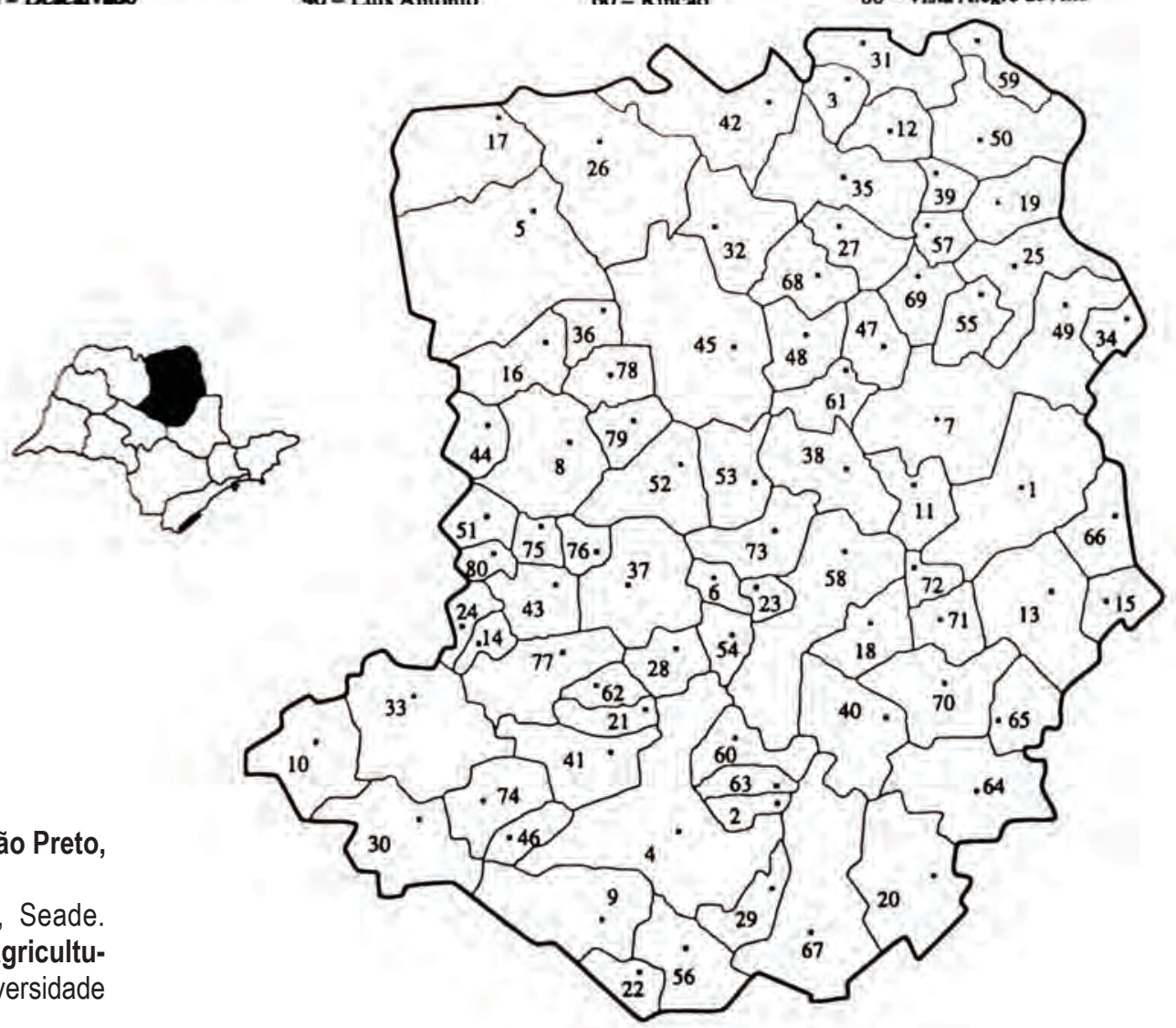
mostra bastante avançada com relação a laboratórios e tratamentos veterinários voltados para a produção de animais para competições, eventos e negócios, através de grandes leilões. Com todas essas indústrias e setores específicos de produção, ainda assim, a cana-deaçúcar e a laranja constituem os principais ramos da agroindústria da região e que provocaram (e continuam provocando) difusões de fluxos e fixos de toda natureza, gerando o dinamismo econômico e a expansão técnico-científico-informacional na região, e exportando o modelo para outras regiões.

A produção de laranja se fixou nos anos 1960 em Matão e estabeleceu taxa significativa de produção na região como o desenvolvimento da indústria processadora de suco, sobretudo os concentrados de laranja voltados para exportação. A região de Ribeirão Preto tem respondido nos últimos anos por cerca da metade da produção estadual de laranja. O município de Bebedouro tem liderado a produção, seguido pelos municípios de Taquaritinga e Monte Azul Paulista, em 1980. Em 1987, os que mais produziam eram Itápolis, Araraquara, Barretos, Colina, Boa Esperança do Sul, Pitangueiras, Santa Rita do Passa Quatro, Matão, Tabatinga, Viradouro, Pirangui e Colômbia ${ }^{45}$. Além da laranja e da cana-de-açúcar, a soja também possui grande importância mundial, devido ao crescimento da agropecuária (sobretudo no que tange à alimentação dos animais) e de seu alto teor de óleo em relação a outras oleaginosas. Com o esgotamento da fronteira agrícola dos EUA, abriram-se oportunidades para o crescimento do cultivo do grão em outros países a partir da década de 1960. Em poucos anos, o Brasil já detinha responsabilidade de $20 \%$ da produção mundial. Em 1980, a região de Ribeirão Preto era responsável por $56,5 \%$ da produção estadual, sendo Guaíra e Morro Agudo os principais produtores da região e do estado. A produção de amendoim nas entressafras de cana-deaçúcar na região também se destaca, sendo $75 \%$ destinados às indústrias de doces, sendo concentrados nos municípios de Sertãozinho, Jaboticabal e Dumont. Frutas como manga e goiaba também entram como culturas de significativo crescimento, concentrando-se nos municípios de Monte Alto, Taquaritinga, Cândido Rodrigues e Jardinópolis maiores produtores paulistas de manga; e de Taquaritinga e Monte Alto, correspondendo a $85 \%$ da produção de goiaba do estado e do país, com praticamente toda a safra destinada às indústrias de alimentos com base na polpa da fruta. 
rando e desenvolvendo vários segmentos de produção industrial de alimentos nos anos 1980, dado o complexo agroindustrial que ali se estabelecera. A concentração de indústrias voltadas para uma produção específica gerou concentração de indústrias de outros setores, que se beneficiaram direta ou indiretamente com o complexo sucroalcooleiro, principalmente no que tange à biotecnologia e a maquinários que favoreciam a fabricação de outros produtos. Tendo em vista as especificidades regionais, a região administrativa de Ribeirão Preto fora reestruturada, sendo subdividida em regiões administrativas menores; alguns municípios rearranjados e outros inseridos conforme a especialização de suas economias. Deste modo, delimitaram-se as regiões administrativas de São José do Rio Preto, a central (tendo a produção citrícola como carro-chefe e como principais polos as cidades de Matão, Araraquara e São Carlos), a de Franca e de Barretos. A região de Ribeirão Preto passou a ser composta por 25 cidades (conforme ilustra a figura 9): Monte Alto, Jaboticabal, Taquaral, Guariba, Pitangueiras, Barrinha, Pradópolis, Guatapará, Dumont, Pontal, Sertãozinho, Ribeirão Preto, Jardinópolis, Brodowski, Serrana, Cravinhos, Luis Antônio, Serra Azul, São Simão, Santa Cruz da Esperança, Cajuru, Santa Rosa do Viterbo, Altinópolis, Santo Antônio da Alegria e Cássia dos Coqueiros.

Essa redução do número de municípios que compõem a região de Ribeirão Preto e a formação de outras duas regiões administrativas pressupõem uma especialização da produção e das relações socioeconômicas das cidades, compondo novas territorialidades. Ao mesmo tempo em que se expandiram as relações por toda a rede urbana, definiram-se cada vez mais os territórios, baseando-se em suas especificidades, na relação de interdependência entre as cidades que compõem a região (sobretudo pelo vínculo estabelecido com o setor sucroalcooleiro), revelando o interesse econômico na região por parte do Estado. A adjetivação "administrativa", conforme visto anteriormente, pressupõe a definição da região como um território que reúne um conjunto de cidades que possuem características socioeconômicas semelhantes, com o intuito de gerenciar e administrar o território político do estado de São Paulo ${ }^{46}$. Segundo dados da Fundação Sistema Estadual de Análise de Dados - SEADE (2010), atualmente a região comporta vários arranjos produtivos associados ao setor energético, sucroalcooleiro, metalomecânico, de biotecnologia, de bioenergia e de saúde (equipamentos médicos, hospitalares e odontológicos ${ }^{47}$ ). À exce-
46. Tal informação é importante para definirmos um objeto inicial mais formal e de entendimento comum que compreenda as relações entre Ribeirão Preto e as demais cidades da região. É importante ressaltar que a eleição de tal região enquanto objeto é apenas uma estrutura comum de onde partirá a pesquisa, não se constituindo objeto engessado no tempo e no espaço, uma vez que as questões abordadas mais adiante irão transpassar os limites de uma organização administrativa.

47. Este último se desenvolveu, dentre diversos fatores, graças à proximidade à presença de institutos de ciência e tecnologia voltados para a área da saúde (como a Faculdade de Medicina da Universidade de São Paulo em Ribeirão Preto, nos anos 1950, e de suas instituições vinculadas, como a Fundação Hemocentro e o Hospital das Clínicas), à formação de mão-de-obra especializada através das escolas de medicina e odontologia em Ribeirão Preto que definiu um mercado consumidor que atraiu fornecedores para a região. 0 que tem sido abordado até 0 momento é a territorialidade da agroindústria sucroalcooleira que estava pareada com os interesses econômicos nacionais durante o período. Obviamente existem outras atividades que reconfiguram a noção de territorialidades na região, porém optou-se em iluminar e enxergar as relações urbanas do ponto de vista de uma economia que movimenta grande parcela do PIB da região de Ribeirão Preto, porque o açúcar e a economia pautada na agropecuária são imprescindiveis para compreensão do processo de urbanização da região. 


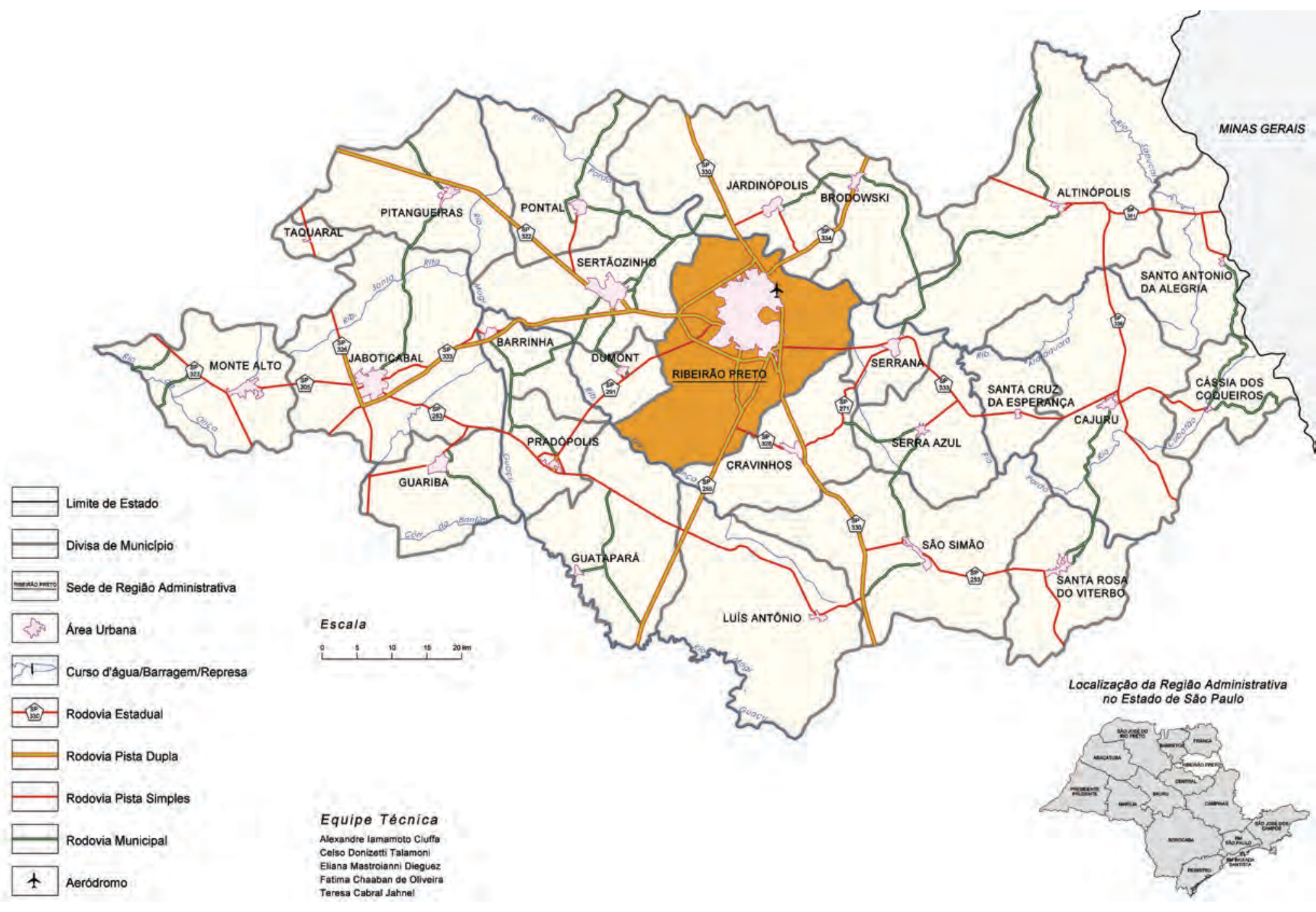

Figura 9 - Região administrativa de Ribeirão Preto, 2007. Fonte: Instituto Geográfico e Cartográfico. Disponível em: $<$ http://www.igc.sp.gov.br/produtos/mapas_ra.aspx?> Acessado em set/2013. 
ção deste último, os demais setores estão vinculados à produção agrícola, caracterizando a região como parte essencial de um Brasil agrícola moderno, estabelecendo vínculos importantes devido a interrelações entre campo e cidade. Sua produção é bastante diversificada, cultivando-se amendoim, café, soja, milho e laranja. O setor pecuário também se destaca com a produção de frangos, ovos e carne bovina, correspondendo a $10 \%$ do valor total da produção da região ${ }^{48}$. Entretanto é o setor sucroalcooleiro que se mantém carro-chefe da economia regional, representando $73 \%$.

As cidades da região se desenvolveram atreladas à economia e a atividades agrícolas e passaram a depender em grande parte dessas atividades, cuja produção e consumo se deram de maneira globalizada. A produção de cana-de-açúcar, apesar de distribuída por todo o território da região de Ribeirão Preto, em 1980, acabou se concentrando nos municípios de Jaboticabal, Ribeirão Preto, Sertãozinho e Pontal, correspondendo a cerca de $30 \%$ de toda a área plantada com essa cultura.

Atualmente, a cidade de Ribeirão Preto responde com uma parcela bem pequena na produção primária, porém se destaca enquanto polo de articulação entre a produção agroindustrial e os mercados financeiros e empresariais externos, para além de sua polarização frente ao consumo consumptível ${ }^{49}$, concentrando shoppings, comércios e serviços de maiores níveis de abrangência. Dada sua posição frente ao setor agropecuário, a cidade passou a deter o título de "capital mundial do agronegócio" a partir dos anos 1980, tendo em vista o papel de destaque do setor agropecuário e da agroindústria sucroalcooleira na economia da região, obtendo relevância em níveis nacional e mundial, caracterizando-se enquanto centro urbano que estrutura a região. A cidade se desenvolveu com um viés destinado aos negócios e ao turismo de negócios, vide sua participação no PIB regional (ver gráfico 2). Este papel da cidade no âmbito financeiro mostrou-se de extrema importância para a mesma enquanto captadora de recursos externos para a região, assim como o sistema de comunicação (como telecomunicações e rodovias, articuladores das propriedades agrícolas, complexos agroindustriais, áreas urbanas, centros empresariais e acadêmi$\cos ^{50}$ e demais estruturas entre si, estabelecendo uma rede de fluxos bastante densa), pois tanto a cidade centralizadora quanto o sistema de circulação passaram a qualificar o nível de integração econômica regional, permitindo a atração de interesses e capitais exteriores.

\section{SEADE, 2004, p. 4.}

49. Consumo consumptível é o momento em que se encerra a cadeia de produção e consumo em um dado recorte. Por exemplo, o produto que chega ao consumidor e que não é parte intermediária de nenhum processo industrial de produção (lazer, entretenimento, alimentos, dentre outros). Diferente do consumo produtivo, que constitui em produtos produzidos de modo a atender a alguma demanda de um processo de produção mais complexo e que resultará em novos produtos que, estes sim, importam para encerrar a cadeia de produção no consumo consumptível (SANTOS, 1984). Definir um objeto, produto ou processo a partir de tais definições é relativo, pois se necessita um recorte, uma abordagem, um foco de análise.

50. A concentração de produção intelectual na região de Ribeirão Preto complementa não apenas a produção agroindustrial, mas também outras produções, possibilitando assim a configuração de uma base técnica comum instalada, constituindo-se enquanto especificidade do território. 


\section{Distribuição do Produto Interno Bruto}

Municipios da Regiāo Administrativa de Ribeirão Preto - 2000-2010

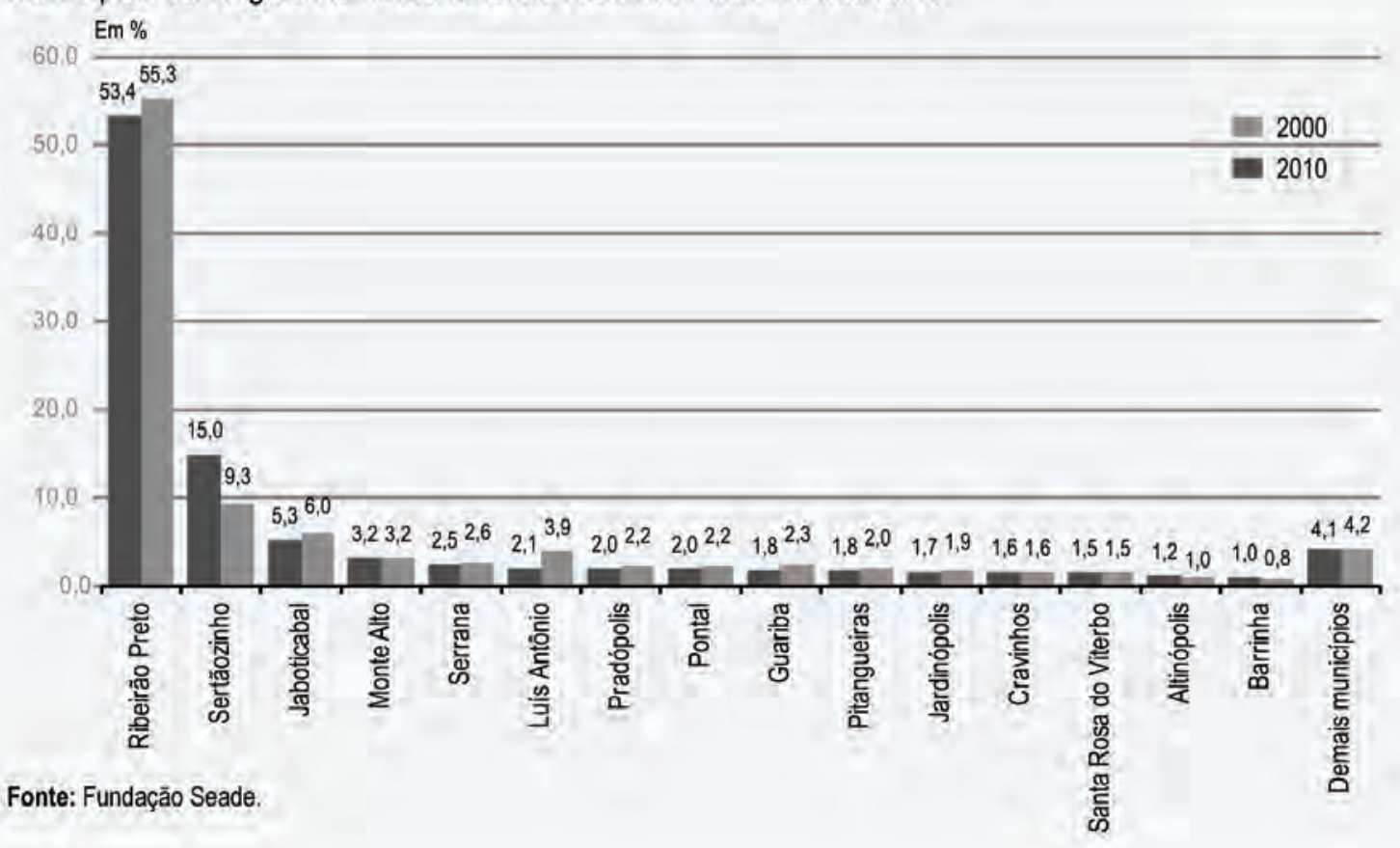

Gráfico 2 - Distribuição do Produto Interno Bruto por município -

Região Administrativa de Ribeirão Preto.

Fonte: SEADE. PIB dos municípios paulistas 2000-2010, p. 64. São 
Conforme pode ser analisado na tabela 3, Ribeirão Preto é o município que mais contribui com o produto interno bruto da região, com $53,4 \%$. Da produção municipal de aproximadamente $R \$ 17$ bilhões, $80 \%$ correspondem ao setor de serviços e 18,9\% ao industrial. A participação da agropecuária é inferior a $0,5 \%$. Em termos relativos, a composição do PIB de Ribeirão Preto é semelhante ao da cidade de São Paulo no período de 2000 a 2010, cuja participação do setor de serviços no PIB municipal era de $79,6 \%$ e o do industrial, de $20,4 \%$, com a diferença da inexistência da participação do setor agropecuário da capital paulista. Serrana, Brodowski e Dumont aparecem em seguida, com $82,5 \%, 75,4 \%$ e $69,1 \%$, respectivamente.

Com relação à participação da produção industrial, os municípios de Luis Antonio, Pradópolis e Sertãozinho são os que mais contribuem, com $62,4 \%, 61,2 \%$ e 58,4\%, respectivamente. A participação de Sertãozinho está associada à produção do complexo metalomecânico de base instalado no município, sobretudo após o Proálcool, cujos investimentos foram destinados, conforme visto, a regiões específicas do estado de São Paulo e até mesmo à própria região Centro-Sul. Dentro de tais regiões, esses investimentos foram bastante focados em setores específicos, como o siderúrgico e o metalomecânico, e em áreas específicas de determinados municípios. A produção agropecuária, apesar de distribuída pela região, acabou se concentrando nas cidades de Guatapará $(38,8 \%)$, Santo Antônio da Alegria $(35,1 \%)$, Taquaral $(30,1 \%)$, Cássia dos Coqueiros $(28,8 \%)$, Altinópolis $(27,3 \%)$, São Simão (26,2\%) e Serra Azul (17,3\%). Em tais cidades, a participação da produção primária ainda supera a da industrial. Entretanto em nenhuma das cidades da região a participação da agropecuária supera a do setor terciário. Nota-se que o setor terciário possui uma participação bastante expressiva nos PIBs municipais, com exceção das cidades de Luis Antonio, Pradópolis e Sertãozinho, que possuem no setor industrial o carro-chefe da economia.

Ao mesmo tempo é importante destacar a alteração no processo de acumulação na região, que por um bom tempo possuiu na exportação de gêneros agrícolas as bases da economia e que, com a industrialização e metropolização, passou a creditar aos setores industrial e de serviços a maior parcela da produção gerada internamente. A região de Ribeirão Preto chegou aos anos 2000 com um PIB cuja produção agropecuária correspondia a menos de $4 \%$. Mas isso não a fez perder sua base econômica agrícola. $\mathrm{O}$ valor adicionado pelo setor indus- 
Produto Interno Bruto e distribuição do Valor Adicionado, por setor de atividade

Estado de São Paulo, Região Administrativa de Ribeirão Preto e Municipios 2000-2010

\begin{tabular}{|c|c|c|c|c|c|c|c|c|c|c|c|c|c|c|}
\hline \multirow[b]{2}{*}{$\begin{array}{l}\text { Regiāo Administrativa } \\
\text { e Municipios }\end{array}$} & \multicolumn{4}{|c|}{ Produto Interno Bruto - 2000} & \multicolumn{4}{|c|}{ Produto Interno Bruto - 2010} & \multicolumn{3}{|c|}{$\begin{array}{l}\text { Distribuiçăo do Valor } \\
\text { Adicionado-2000 (\%) }\end{array}$} & \multicolumn{3}{|c|}{$\begin{array}{l}\text { Distribuiçăo do Valor } \\
\text { Adicionado - } 2010(\%)\end{array}$} \\
\hline & $\begin{array}{c}\text { Total } \\
\text { (em milhŏes } \\
\text { de reais) }\end{array}$ & $\begin{array}{l}\text { PIB per } \\
\text { capita } \\
\text { (em reais) }\end{array}$ & $\begin{array}{l}\text { Participa- } \\
\text { ção do PIB } \\
\text { do Estado } \\
(\%)\end{array}$ & $\begin{array}{l}\text { Participa- } \\
\text { ção no PIB } \\
\text { da RA } \\
(\%)\end{array}$ & $\begin{array}{l}\text { Total } \\
\text { (em milhōes } \\
\text { de reais) }\end{array}$ & $\begin{array}{l}\text { PiB per } \\
\text { capita } \\
\text { (em reais) }\end{array}$ & $\begin{array}{l}\text { Participa- } \\
\text { ção do PIB } \\
\text { do Estado } \\
(\%)\end{array}$ & $\begin{array}{l}\text { Participa- } \\
\text { ção no PIB } \\
\text { da RA } \\
(\%)\end{array}$ & $\begin{array}{l}\text { Agrope- } \\
\text {-cuária }\end{array}$ & Indùstria & Serviços & $\begin{array}{l}\text { Agrope- } \\
\text {-cuária }\end{array}$ & Indústria & Serviços \\
\hline Estado de São Paulo & $424.161,30$ & $11.345,91$ & 100,0 & & $1.247 .595,93$ & $30.264,06$ & 100,0 & & 1,4 & 31,5 & 67,1 & 1,9 & 29,1 & 69,1 \\
\hline RA de Ribeiråo Preto & $10,000,58$ & $9.338,96$ & 2,4 & 100,0 & $31.865,85$ & $25.573,57$ & 2,6 & 100,0 & 3,7 & 24,5 & 71,8 & 3,5 & 29,2 & 67,3 \\
\hline Altinópolis & 103,67 & $6.645,35$ & 0,0 & 1,0 & 370,06 & $23.707,83$ & 0,0 & 1.2 & 25,2 & 7,7 & 67,1 & 27,3 & 6,0 & 66,6 \\
\hline Barrinha & 83,10 & $3.384,39$ & 0,0 & 0,8 & 326,31 & $11.448,43$ & 0,0 & 1,0 & 9,5 & 19,8 & 70,7 & 5,5 & 31,9 & 62,6 \\
\hline Brodowski & 78,32 & $4.512,53$ & 0,0 & 0,8 & 253,62 & $12.017,09$ & 0,0 & 0,8 & 10,5 & 16,0 & 73,6 & 8,9 & 15,7 & 75,4 \\
\hline Cajuru & 98,60 & $4.713,06$ & 0,0 & 1,0 & 285,82 & $12.226,03$ & 0,0 & 0,9 & 12,8 & 16,2 & 71,0 & 13,6 & 19,4 & 67.0 \\
\hline Cássia dos Coqueiros & 15,18 & $5.268,42$ & 0,0 & 0,2 & 40,17 & 15.291 .77 & 0,0 & 0,1 & 23,4 & 9,8 & 66,8 & 28,8 & 10,1 & 61,0 \\
\hline Cravinhos & 160,13 & $5,562,22$ & 0,0 & 1,6 & 521,33 & $16.452,02$ & 0,0 & 1.6 & 10,0 & 25,2 & 64,8 & 5,9 & 33,5 & 60,6 \\
\hline Dumont & 29,99 & 4.690 .68 & 0,0 & 0,3 & 96,25 & $11,819,83$ & 0,0 & 0,3 & 17,7 & 15,4 & 66,8 & 14,5 & 16,4 & 69,1 \\
\hline Guariba & 233,34 & $7,472.52$ & 0,1 & 2,3 & 579.06 & $16.315,80$ & 0,0 & 1.8 & 7.8 & 40,3 & 51,9 & 11,9 & 35,2 & 52,9 \\
\hline Guatapará & 41,76 & $6.516,70$ & 0,0 & 0.4 & 114,69 & $16.464,66$ & 0.0 & 0,4 & 37,5 & 11,8 & 50,6 & 38,8 & 9,3 & 51,8 \\
\hline Jaboticabal & 596,59 & $8.780,78$ & 0,1 & 6,0 & $1.673,71$ & $23.354,05$ & 0,1 & 5,3 & 7,3 & 28,8 & 64,0 & 9,7 & 29,8 & 60,5 \\
\hline Jardinópolis & 188,85 & $6.061,36$ & 0,0 & 1,9 & 538,90 & $14.285,00$ & 0,0 & 1,7 & 12,1 & 19,2 & 68,7 & 8,3 & 23,8 & 67,9 \\
\hline Luis Antônio & 391,01 & $53.970,26$ & 0,1 & 3,9 & 663,25 & $58,767,21$ & 0,1 & 2,1 & 5,7 & 68,3 & 26,0 & 9,2 & 62,4 & 28,5 \\
\hline Monte Alto & 315,39 & $7,190,35$ & 0,1 & 3,2 & $1,014,41$ & $21,746,42$ & 0,1 & 3,2 & 6.9 & 29,7 & 63,4 & 5,5 & 37,9 & 56,7 \\
\hline Pitangueiras & 196,80 & $6.263,22$ & 0,0 & 2.0 & 563,33 & $15,952,03$ & 0.0 & 1.8 & 9.2 & 31.8 & 59.1 & 11,8 & 35.7 & 52,5 \\
\hline Pontal & 215,65 & $7.158,35$ & 0,1 & 2,2 & 623,40 & $15.490,12$ & 0,0 & 2,0 & 8.9 & 40,7 & 50,4 & 8,2 & 39.9 & 51,9 \\
\hline Pradópolis & 218,45 & $16.664,16$ & 0,1 & 2,2 & 639,84 & $36.763,97$ & 0,1 & 2,0 & 2,9 & 59,5 & 37,7 & 4,0 & 61.2 & 34,8 \\
\hline Ribeirăo Preto & $5.529,66$ & $10.848,57$ & 1,3 & 55,3 & $17.004,02$ & $28.100,52$ & 1,4 & 53,4 & 0,4 & 14,9 & 84,7 & 0,3 & 18,9 & 80,8 \\
\hline Santa Cruz da Esperança & 11,79 & $6.538,19$ & 0,0 & 0,1 & 36,78 & $18.835,09$ & 0,0 & 0,1 & 25,5 & 14,1 & 60,4 & 24,4 & 31,8 & 43,8 \\
\hline Santa Rosa de Viterbo & 153,63 & $7,119,03$ & 0,0 & 1,5 & 489,86 & $20.521,09$ & 0,0 & 1,5 & 3,8 & 45,4 & 50,8 & 3,9 & 47.4 & 48,7 \\
\hline Santo Antonio da Alegria & 26,32 & $4.535,67$ & 0,0 & 0,3 & 101,21 & $16.054,14$ & 0,0 & 0,3 & 19,5 & 8,9 & 71,6 & 35,4 & 7,5 & 57,4 \\
\hline Săo Simâa & 76,15 & $5.524,19$ & 0.0 & 0.8 & 247,91 & $17.275,98$ & 0,0 & 0.8 & 17.9 & 15,9 & 66,2 & 26.2 & 18,0 & 55,8 \\
\hline Serra Azul & 27,72 & 3.681 .77 & 0,0 & 0,3 & 82,01 & $7.283,78$ & 0,0 & 0,3 & 25.6 & 13,2 & 61,2 & 17,6 & 13.7 & 68,7 \\
\hline Serrana & 259,74 & 7.821 .29 & 0,1 & 2,6 & 790,10 & $20.315,85$ & 0.1 & 2,5 & 2,2 & $51, \overline{6}$ & 46,2 & 1,3 & 16.2 & 82,5 \\
\hline Sertăozinho & 932,94 & $9.749,38$ & 0,2 & 9,3 & $4.766,75$ & $43.297,09$ & 0.4 & 15,0 & 2,7 & 39,5 & 57,9 & 1,2 & 58,4 & 40,4 \\
\hline Taquaral & 15,80 & $5.767,63$ & 0,0 & 0,2 & 43,05 & $15.792,20$ & 0,0 & 0,1 & 28,4 & 20,0 & 51,5 & 30,1 & 25,7 & 44,3 \\
\hline
\end{tabular}

Tabela 3 - Produto Interno Bruto e distribuição do Valor Adicionado, por setor de atividade.

Fonte: SEADE. PIB dos municípios paulistas 2000-2010, p. 65. São

Paulo, 2012. 
trial inclui tanto os produtos que tiveram sua produção no cultivo da terra e que passaram por processos industriais de transformação (como usinas, destilarias, laticínios, fábricas de doces, refinarias), quanto os insumos voltados para a realização do plantio e cultivo de gêneros agrícolas (maquinário, fertilizantes, defensivos agrícolas, dentre outros), correspondendo aproximadamente a $29 \%$, tal como a média estadual. O mesmo se observa com a participação do setor de serviços, beirando os $70 \%$.

As cidades passaram a representar o suporte para funcionamento da economia monetária do campo, fornecendo serviços que garantem a multiplicação financeira e de tecnologia. Tornaram-se o lugar de regulação da atividade agropecuária moderna e ponto de interseção entre verticalidades e horizontalidades. A década de 1980 marca a instalação das primeiras empresas telemáticas na região de Ribeirão Preto, passando a fornecer informações diversas sobre e para o setor agropecuário de caráter de exportação: informações sobre preços mínimos, normas de crédito rural, políticas públicas, mercado financeiro nacional e internacional, cotações e ações em bolsa de valores e de mercadorias, metais, petróleo e produtos agrícolas. Cotações nas principais bolsas e pregões eram divulgadas aos empresários do setor para que organizassem suas estratégias, articulando a produção agropecuária regional à dinâmica mundializada baseada em fluxos financeirizados e negociáveis.

O complexo sistema de intercomunicações, que permitiu o comércio e o controle empresarial independente das distâncias e que aprofundou as especializações funcionais das cidades, causou uma metamorfose no perfil urbano regional, fazendo-se rever o padrão hierárquico piramidal de funcionamento da rede urbana. No caso da região de Ribeirão Preto, onde as cidades possuem uma inter-relação com o campo - leia-se "produções agrícolas e agroindustriais" -, estabeleceuse uma mesma corrente de relações uníssonas, desenvolvendo inúmeros circuitos espaciais da produção e de cooperação entre ambos os espaços; toda uma grande estrutura voltada predominantemente para uma atividade de produção para exportação, atribuindo às agroindústrias o comando da vida econômica e social das cidades, constituindose também em prática urbana ${ }^{51}$. As atividades consideradas urbanas até então ultrapassaram os limites territorial e administrativo das cidades - como a demanda de funções não agrícolas no campo -, pela relação fornecedor-usuário, expansão do consumo, instalação das agroin- 
dústrias, laboratórios experimentais de pesquisas no campo, serviços financeiros e outros.

A extensão das relações capitalistas à agricultura era uma pré-condição necessária do crescimento urbano. Sem ela, as fábricas da cidade não teriam desfrutado de uma força de trabalho com superabundância de trabalhadores, nem a força de trabalho teria sido reproduzida dentro das cidades na escala necessária para a expansão industrial ${ }^{52}$.

Deste modo, evidenciam-se as polarizações no território; uma hierarquia e uma configuração urbana entre cidades que permitem supor uma contribuição à segregação sócio-espacial do Estado e agentes do agronegócio em nível regional, pois, se os recursos não foram distribuídos homogeneamente em uma região onde praticamente todas as cidades estão articuladas em um mesmo arranjo produtivo, algumas cidades se desenvolveram mais e outras, menos, do ponto de vista econômico. Logo, os recursos captados pelas cidades foram destinados a setores específicos, centralizando e concentrando os investimentos, não proporcionando melhorias da qualidade de vida da população como um todo. O problema da moradia na região, decorrente da urbanização acelerada e da inexistência de políticas públicas habitacionais responsáveis até então, só ganhou visibilidade a partir dos anos 1980, através do Banco Nacional de Habitação $\left(\mathrm{BNH}^{53}\right)$, um dos grandes responsáveis pela dinamização do setor e pela reprodução de cidade para as classes de renda mais baixa na região, que a contemplou com vários programas de financiamento de obras de desenvolvimento urbano.

A especialização e a modernização da produção no território e

52. RODRIGUES, A.M. Produção e Consumo do e no Espaço: Problemática Ambiental. São Paulo: HUCITEC, 1998. apud. ARRUDA, 2013, p. 75.

53. O BNH ajudou a expandir a malha urbana e a construir 0 modelo urbano corporativo fragmentado tal qual se conhece hoje. Entretanto, o problema da carência de domicílios persiste em quase todas as cidades da região, expressando-se dramaticamente nas maiores, onde se nota o crescente aumento da população moradora de cortiços, favelas e habitações precárias (ELIAS, 2003).

54. Esta ideia será retomada mais adiante ao ser abordada a questão dos recursos aplicados na escala da cidade, conformando áreas mais privilegiadas que outras e redefinindo os processos de ocupação e expansão urbanos a nível municipal.

55. ELIAS, 2003, p.259. todas as suas consequências nos padrões de consumo e organização espacial, bem como a setorização na aplicação dos investimentos acentuaram a urbanização na região, deveras fragmentada, diferenciando espaços; produzindo polos de concentração de investimentos, de produção agroindustrial, de segregação socioeconômica, de concentração de capital, especulativos dentre outros; estabelecendo conflitos dentro do próprio território dos municípios ${ }^{54}$; aglomerando populações no espaço urbano. Em 30 anos, a população total da região aumentou $82,3 \%$ (de 985.617 , em 1950, para 1.796 .925 , em 1980) e a população urbana, $294,25 \%$, em contraponto com a redução da população rural (de 601.244, em 1950, para 222.423, em 1991) ${ }^{55}$. Comparado com o ritmo de urbanização do Brasil, o da região foi de extrema rapidez, fazendo com que sua taxa de urbanização estivesse entre as maiores 
do estado de São Paulo, atrás apenas das regiões metropolitana, a administrativa do litoral e a do Vale do Paraíba (ver tabela 4$)^{56}$. Tal aumento populacional e o que ELIAS denomina como redefinição de formas de consumo contribuíram para o crescimento da produção nãomaterial, sendo o consumo a peça chave do processo. A composição do setor de comércio, serviços e atividades específicas se desenvolveu de acordo com a renda da população. Áreas em que a concentração de população de alta renda era maior detiveram prioridades para recebimento de atividades e setores específicos da produção não-material. 0 resultado, para além da polarização, consistiu em um desequilíbrio regional de investimentos, enfatizando a desigualdade e segregação no território regional.

No que tange à industrialização, o complexo industrial da região de Ribeirão Preto aumentou para $4,81 \%$ sua participação no total do valor de produção estadual industrial no final dos anos 1980 . Apesar de a região toda ganhar destaque, as indústrias não estavam distribuídas homogeneamente pelo território, embora fossem encontradas por toda sua extensão. A dispersão industrial pelo território paulista gerou centralidades, de modo que oito municípios da região concentravam, em $1980,56 \%$ do total de indústrias do parque regional ${ }^{57}$. Do mesmo modo, a distribuição de usinas sucroalcooleiras pelo interior do estado também acabou se concentrando em algumas regiões, como em parte da região de Campinas (na área que compreende os municípios entre Piracicaba e Campinas) e na região de Ribeirão Preto - em Sertãozinho, Pontal, Pitangueiras e Jaboticabal (conforme a figura 10).

Em alguns municípios, o campo se esvaziou quase que por completo, deixando-se ao sabor da difusão técnico-científicoinformacional e dos grandes oligopólios de empresas e ao aumento da composição orgânica do território, em virtude de sua menor carga de rugosidades, o que permitiu o aumento da produtividade e do preço da terra. Tal desenvolvimento local esteve associado à produção, ao amparo tecnológico e à organização em âmbito territorial e, sobretudo, pautado na intervenção do Estado, através das administrações públicas, como principais reguladores tanto da produção e consumo, como da elaboração da noção de um território socialmente construído.

Em poucas décadas, o Brasil passou de país essencialmente agrário para uma das principais economias do mundo, pautada na agroindústria e no agronegócio. Os reflexos na produção, na sociedade e no território foram muitos e complexos. A globalização da produção e do
56. Ibid., p. 261.

57. Segundo ELIAS (2003), Franca, Ribeirão Preto, São Carlos eAraraquara possuíam $41 \%$ de todas as indústrias da região. 
Taxas de Crescimento Populacional, por Situação de Domicílio Regióes de Governo

1970-1991

\begin{tabular}{|c|c|c|c|c|c|c|}
\hline \multirow{4}{*}{ Regióes de Governo } & & & & & & prcen \\
\hline & \multicolumn{6}{|c|}{ Taxas de Crescimento Anual } \\
\hline & \multicolumn{3}{|c|}{$1970 / 80$} & \multicolumn{3}{|c|}{$1980 / 91$} \\
\hline & Total & Urbana & Rural & Total & Urbana & Rura \\
\hline \multicolumn{7}{|l|}{ Regiāo Metropolitana de } \\
\hline São Paulo & 4,46 & 4,47 & 4,02 & 1,86 & 1,96 & $-1,79$ \\
\hline Registro & 3.01 & 8.20 & -0.96 & 1.86 & 2,73 & 0,67 \\
\hline 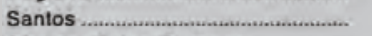 & 3,94 & 4,26 & $-14,09$ & 2,19 & 2,20 & 0,08 \\
\hline São José dos Campos ................... & 6,05 & 7,52 & $-2,81$ & 3,48 & 3,65 & 1,40 \\
\hline Cruzeiro & 1.01 & 2,94 & $-3,92$ & 1,23 & 1,94 & $-1,99$ \\
\hline 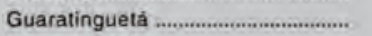 & 1,65 & 2,40 & $-1,17$ & 1,58 & 2,23 & $-2,08$ \\
\hline 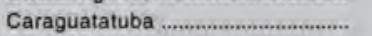 & 6,22 & 8,01 & -8.65 & 4,84 & 5,14 & .6 .93 \\
\hline Taubaté & 3,16 & 5.39 & $-4,41$ & 2,24 & 2,73 & $-1,23$ \\
\hline 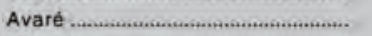 & 0,94 & 3,46 & $-1,90$ & 1,43 & 3,32 & $-2,37$ \\
\hline 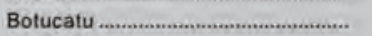 & 0,87 & 3,02 & $-3,44$ & 2,56 & 3,69 & $-1,65$ \\
\hline 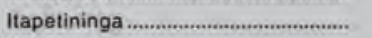 & 2,81 & 4,58 & .0 .26 & 2.85 & 4.10 & .0 .65 \\
\hline Itapeva . . & 2.66 & 5.61 & 0.61 & 1.56 & 3.90 & $-1,18$ \\
\hline Sorocaba ................................... & 4,08 & 5,80 & $-1,73$ & 3,30 & 3,60 & 1,58 \\
\hline Bragança Paulista ............................ & 2,57 & 5,43 & $-1,79$ & 2,54 & 3,83 & $-1,22$ \\
\hline 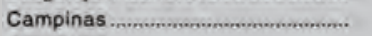 & 6.21 & 7.28 & 0.66 & 3.39 & 4,08 & $-4,19$ \\
\hline 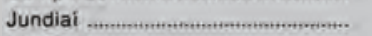 & 4.93 & 5,86 & 1.30 & 2,68 & 3,39 & $-1,89$ \\
\hline Limeira & 3,63 & 4,80 & $-1,16$ & 2,93 & 3,12 & 1,70 \\
\hline Piracicaba & 3,21 & 4,64 & $-2,89$ & 2,70 & 3,11 & $-0,53$ \\
\hline Rio Claro & 2,50 & 3,80 & $-3,38$ & 2,11 & 2,43 & $-0,40$ \\
\hline Săo Joăo da Boa Vista ................. & 1.86 & 3,39 & -0.78 & 1.86 & 3.00 & $-1,15$ \\
\hline Ribeirão Preto & 3.31 & 4,72 & $-3,38$ & 2,86 & 3,39 & -2.36 \\
\hline 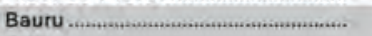 & 2,66 & 4,20 & $-2,43$ & 2,23 & 3,08 & $-3,34$ \\
\hline 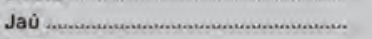 & 2,22 & 3,74 & $-2,34$ & 2,30 & 3,37 & $-4,12$ \\
\hline Lins & 0,35 & 1,26 & $-1,41$ & 0,91 & 2,30 & $-3,14$ \\
\hline Catanduva & 1.77 & 3.55 & -1.31 & 1.42 & 3,36 & -5.23 \\
\hline Fernandópolis & $-0,43$ & 3,36 & 4,89 & 0,41 & 2,25 & $-4,34$ \\
\hline 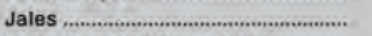 & $-1,80$ & 1,88 & $-5,57$ & 0.27 & 2,05 & $-3,37$ \\
\hline Săo José do Rio Preto .................. & 1.85 & 4.15 & -3.29 & 2.52 & 3,74 & -3.31 \\
\hline Votuporanga & $-0,20$ & 3,08 & $-4,46$ & 0,87 & 2,54 & $-3,62$ \\
\hline 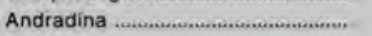 & $-1,45$ & 2,08 & $-7,86$ & 0,81 & 1,73 & $-2,95$ \\
\hline Araçatuba .................................. & 0,66 & 3,15 & $-4,66$ & 1,70 & 2,91 & $-3,85$ \\
\hline 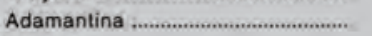 & $\cdot 0,79$ & 1,32 & $-3,06$ & .0 .47 & 2,10 & -5.63 \\
\hline Dracena & $-0,21$ & 1,86 & $-2,71$ & 0,09 & 2,56 & -5.69 \\
\hline Presidente Prudente .......................... & $-0,19$ & 3,12 & $-6,03$ & 1,57 & 2,61 & $-2,37$ \\
\hline 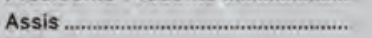 & $-0,32$ & 2.94 & -6.23 & 2,04 & 3,29 & -3.18 \\
\hline 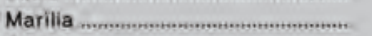 & 0,70 & 2.91 & $-3,48$ & 1,35 & 2,69 & $-3,51$ \\
\hline Ourinhos . & 0.04 & 2.20 & -3.88 & 1.49 & 2,67 & $-2,38$ \\
\hline 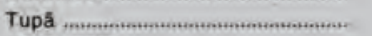 & 0,47 & 3,21 & $-3,03$ & 0,27 & 2,31 & $-5,03$ \\
\hline Araraquara & 2,77 & 4,64 & $-2,38$ & 2,81 & 3,65 & -1.58 \\
\hline 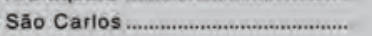 & 3,06 & 4.10 & -1.26 & 2.54 & 3.07 & -1.13 \\
\hline Barretos & 0,93 & 2,61 & -3.63 & 2.64 & 3,60 & $-2,20$ \\
\hline Franca & 1,72 & 3,97 & $-5,07$ & 2,73 & 3,48 & $-2,22$ \\
\hline Săo Joaquim da Barra .................. & 1,23 & 3,42 & $-4,76$ & 1,75 & 2,39 & $-1,62$ \\
\hline
\end{tabular}

Tabela 4-Taxas de crescimento populacional por situação de domicílio. Regiões de governo 1970-1991.

Fonte: Instituto Brasileiro de Geografia e Estatística. Extraído de: ARANHA, V. J.; PERILLO, S. R. Trajetória da urbanização Paulista In: Fundação SEADE. São Paulo em pesquisa, v. 3, n. 3, jul-set. 1993, p. 148.

Disponível em: <http://produtos.seade.gov.br/produtos/spp/index.php?men=rev\&cod=2045>. Acessado em jun/2015. 


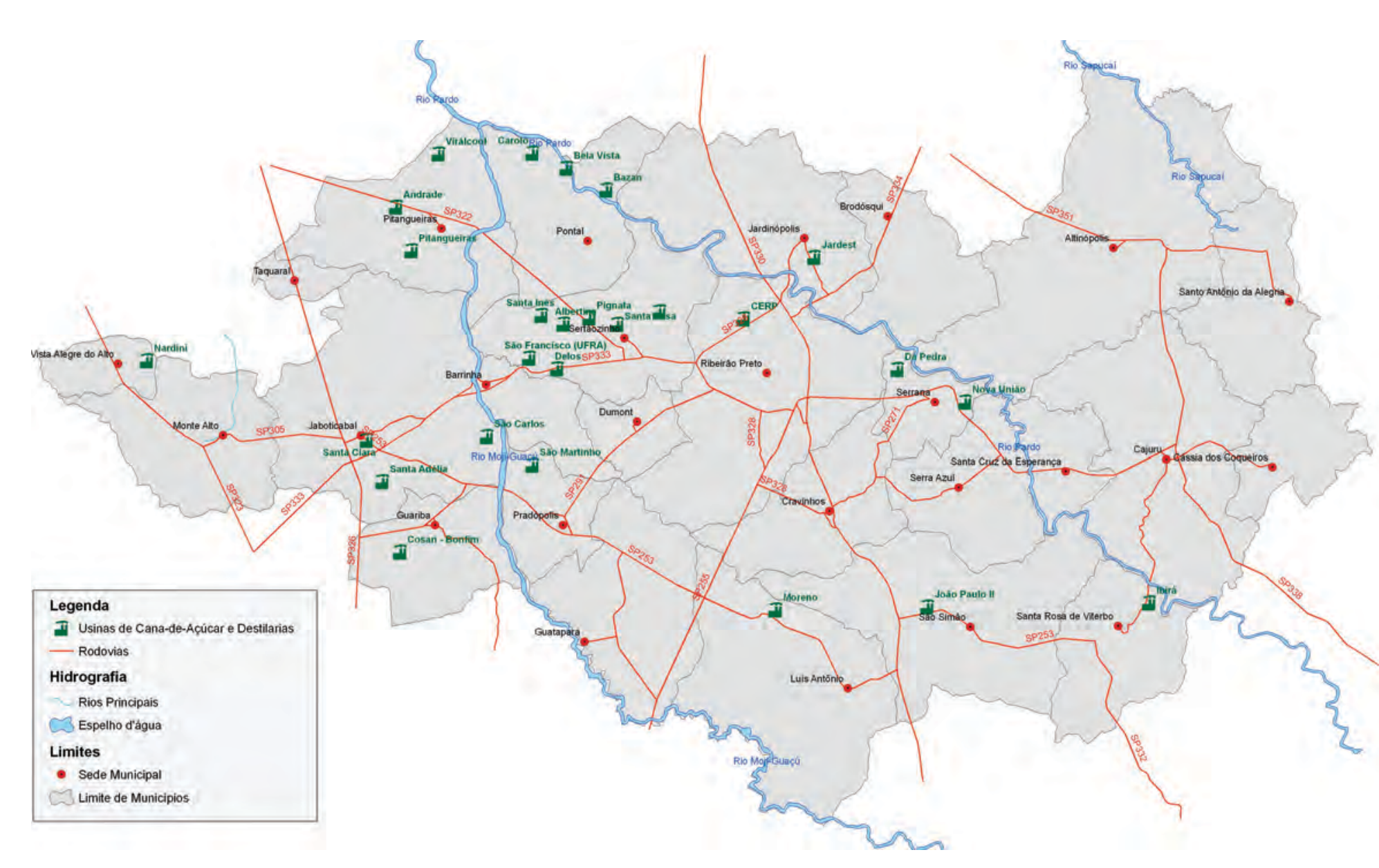


consumo, a reorganização produtiva, a descentralização industrial, guerras fiscais, especializações produtivas do território e reestruturação produtiva da agropecuária são fatores importantes para a compreensão do fenômeno, sobretudo no interior do estado de São Paulo. A mudança na base técnica da produção agropecuária, tal como o processo de modernização do campo e os avanços nas redes técnicas de comunicação e informação desencadearam uma série de transformações na sociedade como um todo, sobretudo no território, intensificando os processos de urbanização e crescimento urbano, criando-se novas horizontalidades - condições e resultados da modernização da produção, expandindo os sistemas de objetos - e verticalidades - como mudanças na estrutura fundiária resultantes das novas demandas dessa produção, de intercâmbio e de regulação ${ }^{58}$.

Conforme visto, uma vez reestruturada e reincorporada ao sistema de acumulação, a produção agropecuária passou a usufruir da rede urbana para se constituir enquanto campo produtivo, propiciando uma reconfiguração territorial e uma necessidade de redefinição de divisões regionais, regiões metropolitanas e cidades de menor escala atualmente empregados para estudos e análises sobre a questão. Dados os avanços nos meios da produção agropecuária, a partir dos anos 1980, o aumento das quantidades produzidas em relação às superfícies plantadas conduziu a atividade a uma demanda extrema de comércio, de modo que o dinheiro passou a se tornar informação indispensável. A produção nacional que outrora caracterizava a história econômica e a ocupação de seu território, quatro séculos mais tarde viu o valor de troca, em detrimento do valor de uso, tornar-se hegemônico para a produção de alimentos no país. A agropecuária se constituiu padrão estandardizado de produção e consumo alimentícios, com a finalidade suprema de produção de mercadoria para consumo de massas em nível global ${ }^{59}$.

As economias ditas emergentes passaram de importadoras para exportadoras líquidas de capital, inicialmente sob a forma de pagamentos dos juros da dívida externa e, posteriormente, como produtor de ativos financeiros de alta rentabilidade. Em 1980, após uma crise de dívidas (como a onda de moratórias que assolou a América Latina), a periferia se tornou mercado emergente, no sentido de ser o lugar da valorização financeira sempre possível, ainda que guarnecido por instrumentos e políticas econômicas para maximizar o ganho, minimizando riscos e evitando sustos. A industrialização, portanto, se inseriu no movimento 
de internacionalização financeira indireta dos sistemas nacionais fechados, um prelúdio do desenvolvimento do regime de acumulação sob a dominância da valorização financeira ${ }^{60}$. No caso do Brasil, o panorama era de um declínio da capacidade econômica de formação de capital e um crescimento de despesas com rendas e investimentos. Neste período, também veio à tona o processo de mecanização da produção agropecuária - e não foi por acaso. A tecnologia e o maquinário foram indispensáveis na periferia do sistema capitalista, para formação bruta mais vigorosa de capital fixo, e necessários para a industrialização periférica da nova forma de valorização, pautada na internacionalização da produção ${ }^{61}$. A industrialização da periferia respondeu tanto pelos anseios do capital em novos locus de investimento produtivo, quanto pelos anseios de uma esfera financeira em expansão e autonomização. Ela deu uma sobrevida ao processo de acumulação estritamente produtivo, enquanto preparava as condições para a dominância financeira que adveio.

Assim sendo, a natureza da relação de dependência do capitalismo periférico brasileiro ao centro do sistema se alterou, segundo Singer (1998), para uma dependência desejada ${ }^{62}$, uma vez que todos os países passaram a depender crescentemente do fluxo de capitais financeiros; ou para um caso de servidão financeira, segundo Paulani. Tal dependência, ou servidão, se mostra como expressão interna do próprio capital, como um tipo específico de relação entre as classes e grupos, implicando uma situação de domínio que mantém estruturalmente a vinculação econômica com o exterior, com o centro do sistema. Neste mesmo período, era dada continuidade à segunda fase do Proálcool, ampliando-se a meta de 3 para 10 bilhões de litros até 1985, incentivando-se a expansão da produção sucroalcooleira, fomentando-se sua mecanização e industrialização. O estado de São Paulo, enquanto principal centro de produção, desenvolveu o programa Pró-Oeste, em 1980, através da Secretaria da Agricultura e Abastecimento, distribuindo recursos da Comissão Executiva Nacional do Álcool - CENAL para o oeste do estado, com a finalidade de implantar novas estruturas produtivas e ampliar as já existentes. Com isso, o programa beneficiou cidades como Presidente Prudente, Araçatuba, Bauru e o oeste da região de São José do Rio Preto, contribuindo para uma territorialização mais ampla da produção sucroalcooleira para além das regiões iniciais do Vale do Paranapanema, de Ribeirão Preto, Jaú, Araraquara e de Piracicaba.
60. PAULANI, 2008

61. Ibidem.

62. SINGER, Paul, De dependência em dependência: consentida, tolerada e desejada, Estudos Avançados, São Paulo, v. 12, n. 33, maio/ago. 1998, p. 119-30. 
63. Segundo dados do relatório referente à violência do Conselho Indigenista Missionário - CIMI, das 1047 áreas reivindicadas por povos indígenas, apenas 33\% estão regularizadas. Além disso, foram contabilizados entre 2012 e 2013 cerca de 1400 tentativas de assassinato de indígenas, sendo que pelo menos 60 índios foram assassinados em 2012 e 53 durante 0 ano de 2013 em consequência de conflitos relacionados à disputa de terras, dos quais 33 ocorrências foram localizadas no Mato Grosso do Sul. Ver: <http://novo.mst.org.br/2014/07/17/pelomenos\%2053-ndios-foram-assassinados-em\%202013diz-cimi.html>
Assim como outros processos descritos até então, a produção agroindustrial, a destinação de recursos e o desenvolvimento de arranjos produtivos em outras regiões compreenderam um conjunto de intenções políticas na reestruturação da produção no território em um processo maior, mais amplo, ao que se insere a região de Ribeirão Preto, transpassando limites administrativos regionais. Sertãozinho e Pontal acabaram concentrando grande parte das usinas e destilarias do estado, dados as vantagens da região no início do processo de espacialização da produção e de seu grau de especialização. Entretanto, como pode ser visto na figura 11, exceto na região sul e no litoral do estado, usinas e destilarias foram implantadas, ocupando praticamente todo o estado de São Paulo. Essa descentralização produtiva fomentada pelo Estado legitimou também a consolidação da ocupação do território estadual, promovendo a formação de novas aglomerações urbanas através da ampliação do território da economia de produção canavieira.

Conforme visto até então, pode-se notar que a atividade agroindustrial, em destaque a sucroalcooleira, ainda que focada nas regiões Nordeste e Centro-Sul, com aplicação mais intensa de recurso nesta última, constitui uma territorialidade que transpassa limites administrativos internos, sendo delimitado apenas pela fronteira nacional e por fronteiras ambientais, conforme pode ser observado na figura 12. À tal espacialidade estão incorporadas as diversas relações que a agroindústria estabelece entre cidade, campo e indústria, ampliando a noção do território de disputa (inclusive entre setores internos agropecuários), articulando usinas, indústrias, áreas de cultivo de matéria-prima, sistemas de transporte e distribuição, aglomerações urbanas, sobretudo fluxos de mão-de-obra sazonais que relacionam, por exemplo, regiões Norte e Nordeste à produção sucroalcooleira da região Centro-Sul pelo viés da força de trabalho.

É importante destacar que os conflitos gerados pelo agronegócio, para além da exploração do trabalhador nas lavouras, estão relacionados principalmente pela disputa da terra. Nas regiões da fronteira agrícola, os conflitos ocorrem na expansão de áreas para agropecuária (pastagem e grãos) versus reservas florestais (complexo Amazônico), propriedades indígenas ${ }^{63}$, ribeirinhas e quilombas (SAUER, 2014). Nas regiões já consolidadas do Centro-Sul e Nordeste, os conflitos se dão na esfera da disputa entre agricultura familiar e o grande latifúndio. No primeiro, os conflitos estão na esfera da expansão do sistema, já no segundo, em uma reestruturação produtiva. 
Figura 11 - Usinas de Cana-de-Açúcar e Destilarias no estado de São Paulo-2008.

Fonte: Secretaria de Energia do Estado de São Paulo. Disponível em:

<http://www.energia.sp.gov.br/portal.php/mapas_biom assa>. Acessado em: nov. 2014.

Figura 12 - Histórico da produção total sucroalcooleira do Estado (1998-2012).

A produção de cana-de-açúcar se concentra nas regiões Centro-Sul e Nordeste do Brasil. O mapa indica em vermelho as áreas onde se concentram as plantações e usinas produtoras de açúcar, etanol e bioeletricidade, segundo dados oficiais do IBGE, UNICAMP (Universidade Estadual de Campinas - SP) e do CTC (Centro de Tecnologia Canavieira). As setas indicam até onde a produção pode se expandir sem comprometer 0 bioma amazônico. Fonte: Unica - União da Agroindústria Canavieira do Estado de São Paulo. Disponível em: <http://www.unica.com.br/mapa-daproducao/>
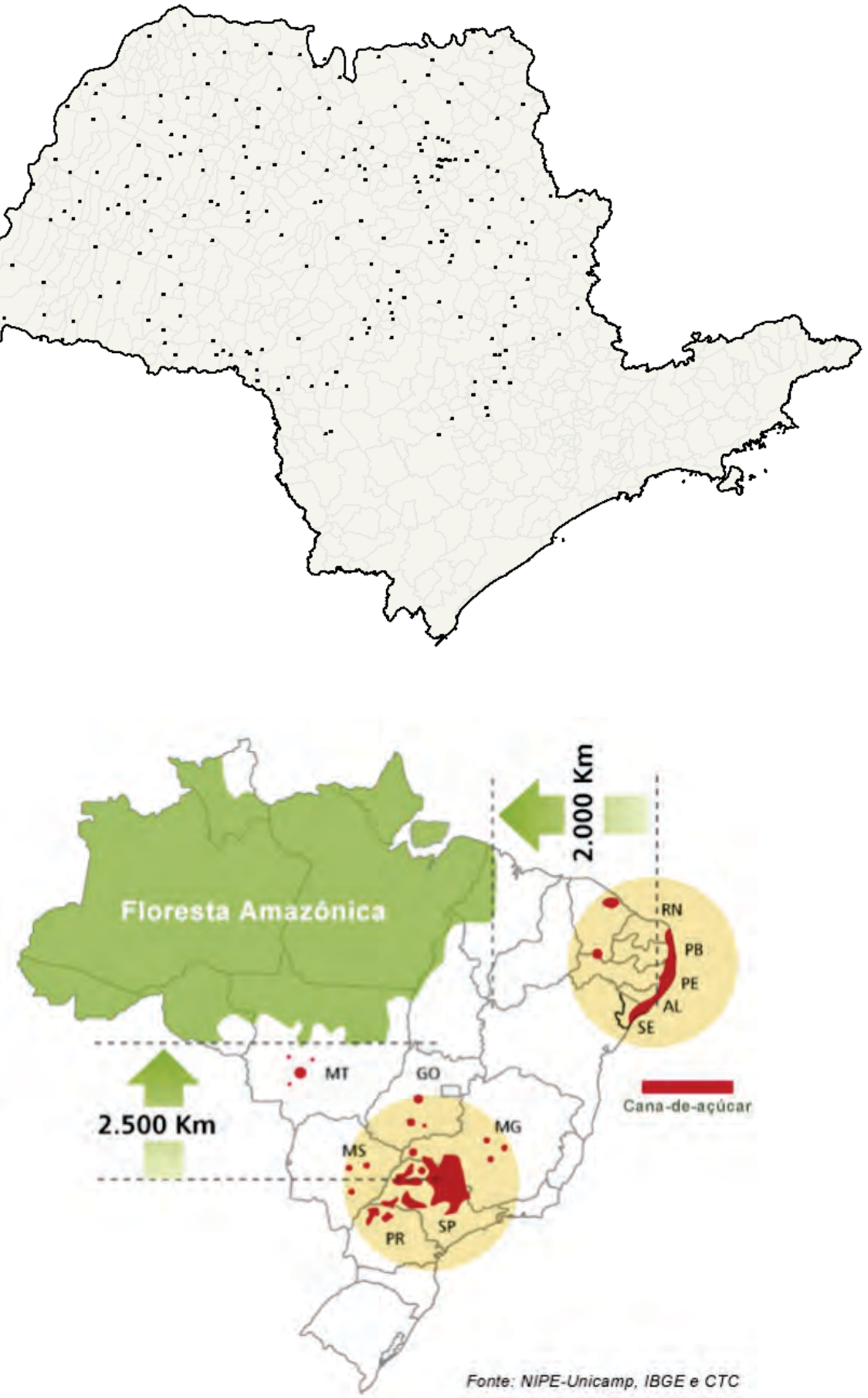
Segundo SILVA (2010), a agroindústria brasileira carrega ao menos três características: uma modernização conservadora que sustenta contradições fundiárias com base na monopolização de terras por parte de grandes proprietários rurais; as relações com o Estado, baseadas no patrimonialismo e na naturalização de desigualdades sociais; e um caráter autoritário, como as relações entre usinas e seus trabalhadores e com instituições de regulação social e ambiental. A modernização da indústria agrícola, apesar de ter alcançado altos índices de produtividade, também trouxe graves consequências no âmbito urbano, como o agravamento de impactos ambientais, desemprego e a precarização das relações de trabalho.

É necessário explicitar que a agroindústria abrange diversos nichos e níveis de mão-de-obra. Segundo FREDERICO (2011), as profissões relacionadas ao setor sucroalcooleiro e a qualquer outra produção do campo moderno estão organizadas em uma forma piramidal. No meio da pirâmide encontram-se os técnicos; mais próximos do topo, profissionais com maior qualificação, como engenheiros agrônomos, economistas, administradores, tecnólogos, cientistas de Tecnologia da Informação (TI), químicos, gerentes de produção e administrativos; no topo, os produtores das informações. De fato, com o aumento da especialização da produção, aumentou-se a procura por mão-de-obra qualificada nas aglomerações urbanas. A tais categorias fazem jus os dados que se divulgam do setor, informando que os trabalhadores possuem registro em carteira de trabalho, com direitos trabalhistas, recebendo, em média, 3,5 e 5,3 salários mínimos, respectivamente, os trabalhadores nas lavouras e os profissionais na indústria sucroalcooleira.

Mas é na base da pirâmide que se encontram os trabalhadores menos qualificados, terceirizados, assalariados rurais, com menor conteúdo em informação, mas que são a peça chave de toda a produção mundial sucroalcooleira. Segundo a Confederação dos Trabalhadores na Agricultura (Contag), estima-se que em 2007 havia no Brasil cerca de cinco milhões de trabalhadores assalariados rurais.

64. VERAS, D. Convenções e acordos coletivos. Florianópolis, janeiro/2007. Disponível em: $<$ https://sites.google.com/site/dauroveras/convencoes_c

A extensão das relações capitalistas à agricultura era uma pré-condição necessária do crescimento urbano. Sem ela, as fábricas da cidade não teriam desfrutado de uma força de trabalho com superabundância de trabalhadores, nem a força de trabalho teria sido reproduzida dentro das cidades na escala necessária para a expansão industrial ${ }^{64}$. 
No caso da colheita da cana-de-açúcar, estima-se que atualmente esteja empregado algo em torno de um milhão de trabalhadores em todo o país. Se por um lado existe uma evolução e um progresso técnico-científico e produtivo na produção agrícola (sobretudo do açúcar e do etanol paulista), essa mesma produção se contradiz ao se analisar a problemática da mão-de-obra explorada dos cortadores de cana e dos boias-frias.

A mecanização de frações do processo produtivo causou uma maior captação de força de trabalho temporária, em detrimento da manutenção de trabalhadores residentes contratados, gerando, assim, um excedente de força de trabalho. A este excedente somam-se os imigrantes das regiões norte e nordeste do país, que vão para as regiões das usinas em busca de trabalho. Os imigrantes, em sua grande parcela, são formados por negros e pardos, provenientes de áreas mais pobres das regiões de origem, caracterizando uma segmentação da força de trabalho. Se a ocupação do território paulista no início do século $X X$ fora concebida por imigrantes que adquiriram suas terras, a produção agroindustrial do século XXI tem na imigração de trabalhadores fortes raízes para sua realização.

Se por um lado se fala em uma evolução da técnica nos processos agroindustriais, por outro a agroindústria possui raízes em uma realidade arcaica e exploradora. Para a realização do aumento produtivo das agroindústrias encontra-se uma grande contradição do suposto "progresso da produção sucroalcooleira", localizado na etapa de corte e colheita. Essas etapas ainda são bastante precárias e geram uma problemática gigantesca no que tange à exploração da mão-de-obra do trabalhador agrícola. Quanto mais se produz, mais se corta, mais se colhe, mais se explora.

Os trabalhadores safristas são tidos como mão-de-obra invisível, uma vez que não são computados por estatísticas oficiais, pelo fato de serem temporários. Porém são responsáveis pelo aumento populacional em épocas de safra nas cidades onde predominam os canaviais. Características coronelistas prevalecem nas relações entre trabalhadores e usineiros, dadas as condições precárias de trabalho e de vida dos trabalhadores, balizada por uma série de coerções que desencadeiam, assim, regimes de exploração e escravidão. O salário é pago pela produção do trabalhador, não pelos dias trabalhados, ou seja, o trabalhador ganha por tonelada de cana cortada. A promotoria do estado de São Paulo se posiciona contra essa modalidade de remuneração, pois atri- 
65. SILVA, Maria A. M. Mortes e acidentes nas profundezas do 'mar de cana' e dos laranjais paulistas. In: INTERFACEHS - Revista de Gestão Integrada em Saúde do Trabalho e Meio Ambiente. v.3, n.2, Artigo 1, abr.l agosto 2008. Segundo a Convenção Coletiva de Trabalho "Setor Canavieiro" de 2007-2008 firmada entre os Sindicatos Rurais e a Federação da Agricultura do Estado de São Paulo - FAESP, o piso salarial durante a vigência (de maio de 2007 a abril de 2008) era de $\mathrm{R} \$ 445,00$ por mês, $\mathrm{R} \$ 14,83$ por dia e R\$2,02 a hora. No estado de São Paulo, os usineiros pagam algo em torno de $\mathrm{R} \$ 2,50$ a $\mathrm{R} \$$ 3,00 por tonelada de cana cortada.

66. Equipamentos de proteção individual (EPIs) não eram fornecidos, não havia descanso, muitos passavam fome. Além disso, a moradia, transporte e alimentação fornecidos pelas usinas eram bastante precários. Para piorar a situação, um mercado da região cobrava preços abusivos dos produtos comercializados.

67. Neste sistema, o espaçamento entre as leiras colhidas será maior, representando menores trajetos percorridos por caminhões e carregadeiras. Economiza-se óleo diesel e tempo para rolagem de cana, mas onera ainda mais o trabalho manual (OTANI, M., YOSHII, R. Implicações socioeconômicas da mudança técnica no sistema de colheita de cana-de-açúcar, de cinco para sete ruas. Gabinete da Secretaria de Agricultura e Abastecimento. São Paulo, março, 1983.

68. Na madrugada do dia 15 , os acessos à cidade foram bloqueados e então se iniciou uma série de atos de rebelião que se desenrolou pelos três dias seguintes. Iniciouse pela destruição do escritório e de patrimônios da SABESP (veículos e bomba dosadora de cloro do sistema) que terminou com ação truculenta da tropa de choque da polícia. No mesmo dia, depredaram e saquearam o supermercado Santo Antônio Maria Claret. No dia seguinte, incendiaram o canavial da Usina São Carlos.

69. Faziam parte da pauta de exigências o fornecimento de transporte seguro e gratuito; de ferramentas e de EPIs; folga semanal remunerada; pagamento por dias não trabalhados devido a imprevistos naturais; décimo terceiro salário; fiscalização do pagamento e aumento de salários; restauração do sistema de corte de sete para cinco ruas. bui à mesma a responsabilidade da exploração. Já sindicatos e usineiros defendem que os trabalhadores ganhariam menos com o regime de dias de produção, pelo fato de o piso salarial ser bastante baixo ${ }^{65}$.

A situação de exploração costuma ser bastante recorrente nas fronteiras agrícolas, localizadas mais ao interior do território nacional. Entretanto, no centro dinâmico e moderno do agronegócio e da produção agrícola, existem denúncias de relações escravistas de trabalho desde os anos 1970, quando a monocultura canavieira se estabeleceu na região, tendo perdurado até os dias de hoje. Ao abordar a exploração da mão-de-obra canavieira, é de imprescindível relevância citar o levante de Guariba, de 1984.

Localizada na região de Ribeirão Preto, Guariba possuía população aproximada de 16 mil habitantes, sendo 10 mil de cortadores de cana, tendo a produção agrícola como carro-chefe da economia desde o período do café. A maior parte dos moradores e trabalhadores era composta por migrantes provindos de vários estados, principalmente da Bahia, de Minas Gerais (Vale do Jequitinhonha) e do Maranhão. Atualmente estão instaladas no município quatro usinas canavieiras: Usina Bonfim - Açucareira Corona (COSAN); usina Santa Adélia; Usina São Martinho; e Usina São Carlos. Em 2014, a cidade comemorou os 30 anos de uma das, se não a maior e mais importante greve do setor canavieiro da história do país.

Se no atual contexto os trabalhadores dos canaviais já enfrentam uma série de problemas, a situação em Guariba, em 1984, era muito pior. Usinas e grandes proprietários se beneficiavam com o esquecimento e marginalização dos trabalhadores e também com a exploração infantil nos canaviais, colocando essas pessoas em condições extremamente precárias ${ }^{66}$. O estopim do levante se deu com a redução drástica dos salários (em virtude da inexistência de direitos trabalhistas, da inexpressividade dos sindicatos e da alteração do sistema de corte da cana-de-açúcar por parte dos usineiros, passando de cinco para sete ruas ${ }^{67}$ ) e com o aumento absurdo de $900 \%$ da conta de água fornecida pela SABESP. Na noite de 14 de maio de 1984, sem nenhum apoio sindical, os trabalhadores se organizaram e então foi declarada a greve $^{68}$. Após três dias de rebeliões, foi assinado o Acordo de Guariba, atendendo às reinvindicações dos trabalhadores ${ }^{69}$, tornando-se fator de grande peso na elaboração de posteriores normas regulamentadoras do trabalho agrícola e principalmente na conquista de direitos trabalhistas para os cortadores de cana. 
O levante não só teve um impacto bastante forte nas relações de trabalho entre cortadores e usineiros da própria cidade, mas também influenciou e incentivou lutas em outras cidades da região, em termos de pensamento de rede urbana. Segundo reportagens de jornais da época, a revolta

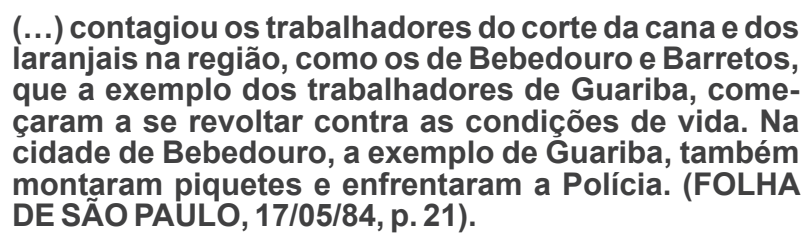

Evidenciou-se um arcaísmo enraizado na exploração da principal força motriz da produção agroindustrial. Ao se analisar que o aumento da área plantada de produção de cana-de-açúcar obteve um salto de 2.768.514 ha, nos 1980, para 9.616.615 ha, em 2011, atentando-se principalmente ao aumento da produção de cana-de-açúcar no estado de São Paulo (de 107,98 t, em 1983, para 444,39 t, em 2011), deixa de ser impossível não estabelecer um patamar de contradição entre produtividade e avanços tecnológicos da agroindústria, de um lado, e exploração da mão-de-obra, do outro. Isso porque, ainda que os investimentos crescentes na biotecnologia permitam o aumento da produção de cana-de-açúcar, ainda que máquinas colheitadeiras propiciem uma velocidade maior da execução, ainda que as áreas de plantações tenham se ampliado por todo o território nacional, o cortador de cana permanecerá ali, na base de todo o complexo agroindustrial sucroalcooleiro.

As relações conflituosas dos cortadores de cana com a exploração do trabalho também evidenciaram o caráter urbano dos conflitos do trabalhador do campo e suas consequências em nível urbano intrarregional, contribuindo para a promoção de desigualdades socioterritoriais (ver figura 13), através da reestruturação do território por meio dos arranjos produtivos. 

Conforme visto, a disposição de arranjos produtivos no território promoveu grandes desigualdades territoriais ora realocando, ora atraindo, ora expulsando atividades e populações. No que tange à agroindústria, seus arranjos acabaram reproduzindo inclusive o arcaísmo presente na tradicional estrutura produtiva agropecuária, através da exploração do trabalho travestida de avanços tecnológicos. Tais arranjos tiveram parcela do território urbano das cidades e a rede urbana como principal mecanismo para sua reestruturação, e ainda as têm para sua realização. Além das indústrias, destacaram-se também as pequenas e médias empresas (MPEs) no contexto da espacialização da produção no território e na reorganização da produção, que deixou de ser configurada na imagem de uma única empresa dotada de todos os modos de produção, mas em uma estrutura de rede de relações e distribuição das etapas produtivas entre empresas. A cooperação entre empresas e indústrias passou a ser imposta pela velocidade de interdependência e aumento da produtividade e da competitividade entre atores no mercado, de modo que. EGLER destaca que as componentes fundamentais da dinâmica regional repousam nas relações que se estabelecem entre centros e periferias, entre as cidades e entre estas e o campo $^{70}$. Isto se deve aos novos padrões de integração produtiva e financeira que induzem reestruturações econômicas, redefinindo a divisão internacional territorial do trabalho (produzindo desigualdades espaciais) e a estrutura das relações cidade-campo e, consequentemente, o redesenho das redes urbanas.

Ao se tratar da organização de grandes estruturas é comum definir hierarquias e níveis para classificação de seus componentes. Com a rede urbana não seria diferente: alguns centros urbanos tendem a se destacar mais do que outros, estabelecendo mais ou menos interligações, influenciando mais ou menos outras cidades da rede. Alguns o fazem em nível internacional, articulando-se com as principais capitais do mundo; outros influenciam territórios em nível nacional; outros, ainda, possuem uma área mais restrita, e assim a rede urbana também permite pensar em uma rede de influências e tensões socioeconômicas entre as cidades. Um exemplo é a definição atual de Ribeirão Preto pelo IBGE como uma capital regional de capacidade de gestão no nível imediatamente inferior ao das metrópoles nacionais, tendo "área de influência de âmbito regional, sendo referida como destino, para um conjunto de atividades, por grande número de municípios"71. É perceptível, portanto, que tais relações de influências e as hierarquias estejam direta-
A REGIÃO METROPOLIZADA

70. EGLER, C. Questão regional e gestão do território no Brasil. In: CASTRO; CORREA; GOMES. Geografia conceitos e tema. Rio de Janeiro: Bertrand Brasil, 2000.

71. IBGE, 2008, p. 11. 
72. Segundo Sposito (2006), para investigá-las e localizálas, leva-se em consideração o tamanho populacional (apesar de não ser o essencial), o tamanho econômico (relacionado às dinâmicas econômicas e articulação de infraestruturas da cidade com relação à região onde está inserida), o grau de urbanização, a centralidade na articulação entre centros urbanos e seu fornecimento de bens e serviços, e a qualidade de vida urbana. Também são considerados o fator de equilíbrio e estabilidade de sistemas urbanos no território e um reconhecimento e sentimento de pertencimento da população, dada a escala da cidade, menores conflitos sociais e ambientais - não que eles inexistam, mas os índices de resistências são menores - e também de custos sociais. Por outro lado, menor diversidade sociocultural, menor poder de competitividade econômica e maior dificuldade de acesso aos fluxos de informação e capital mente ligadas com os grandes nós da rede urbana, representados pelas grandes metrópoles.

Um termo que ganhou bastante destaque na discussão a partir de meados da década de 1990 foi cidades médias, em decorrência do aumento de poder de polarização das grandes aglomerações urbanas e das novas dinâmicas produtivas territoriais. Segundo alguns autores, o avanço tecnológico, sobretudo nas comunicações, permitiu a dissociação entre os centros de tomada de decisão e os centros produtivos, de modo que se abriram novas perspectivas locacionais para as chamadas cidades médias ${ }^{72}$. SPOSITO e MAIA (2006) definem como cidadesmédias as cidades que detêm certo papel regional ou de intermediação no âmbito da rede urbana, estabelecendo um nó, considerando relações locais, regionais, nacionais e internacionais, tendo em vista sua importância e relevância na conformação de um sistema urbano, juntamente articuladas com atores locais públicos e privados. Não se restringem apenas a uma designação legal ou a uma margem de contingente populacional. Suas funções e papel desenvolvido nas redes urbanas nas várias escalas são imprescindíveis. Tais cidades possuem indicadores semelhantes aos encontrados nas grandes metrópoles - como a descentralização, a verticalização, a expansão via loteamentos e condomínios fechados, a alteração de espaços agrícolas em urbanos e o rearranjo de usos de bairros e a estratificação do uso do solo -, ao mesmo tempo em que apresentam diferenças quantitativas (menores números de habitantes, de automóveis, equipamentos públicos, indicadores socioeconômicos relativos) e qualitativas, como a vida urbana e o cotidiano. Além disso, nas cidades médias a relação centro-periferia não se define pela distância, dadas as dimensões das cidades, por mais esparsas que sejam, mas pelas diferenças sociais, pela segregação social e pelos padrões de ocupação e (re)produção da cidade.

De fato, existe uma hierarquização das cidades que compõem a rede, mas de um ponto de vista econômico e que não necessariamente possui relação direta com sua dimensão, extensão e escala. Conforme visto anteriormente, em dados relativos, os PIBs da região de Ribeirão Preto e da região metropolitana se assemelham, os processos de segregação socioterritorial são os mesmos e a presença do setor terciário na economia das cidades, associada a processos de urbanização e metropolização tem articulado as cidades de ambas as regiões do mesmo modo. Tal hierarquização está relacionada com a importância da cidade ou região para determinados mercados ou processos de acu- 
mulação ou reprodução de capital. Além disso, existe uma gama enorme de níveis de influência em centros urbanos que não correspondem a regiões metropolitanas, dificultando a localização e definição de tais cidades. Deste modo, a definição de cidade-média contribui para o pensamento acadêmico e o debate regional, mas parece não contemplar a complexidade de Ribeirão Preto e sua participação na composição regional e na rede urbana, pois grande parte de suas relações está dissolvida pela região, ou seja, não é possível pensar a cidade de Ribeirão Preto sem a dinâmica socioeconômica de sua região e de outras pelas quais é influenciada, sobretudo a região metropolitana de São Paulo. Daí o conceito de região metropolizada contribuir mais com a análise. Trata-se da extensão de uma compreensão e reprodução urbanas, cujo protagonismo não é necessariamente atribuído à escala da cidade.

Por muito tempo o senso comum afirmava uma divisão do estado paulista em capital e interior, associando a cada uma dessas definições um conjunto de características que as tornam distintas entre si. À capital associavam-se aspectos como indústria, expansão urbana, violência, economia, desenvolvimento avançado e tecnologia; e ao campo, a figura do sertanejo, da roça, do atraso, o ritmo lento de desenvolvimento, o pitoresco e a natureza quase sem alterações. Ao analisarmos a região de Ribeirão Preto atualmente é preciso observar que ela

\begin{abstract}
ocupa o quinto lugar em termos de concentração da população paulista e caracteriza-se pelo seu dinamismo. Em 2002, contava com uma população projetada de aproximadamente 1,1 milhão de habitantes. Como na Região Metropolitana de São Paulo, quase $97 \%$ da população está concentrada em áreas urbanas. Tratase de um dos maiores índices do Estado, sendo superado apenas pela Região Metropolitana da Baixada Santista. As taxas de urbanização oscilam de $68 \%$, em Guatapará (a menor da região), até $99,6 \%$, em Ribeirão Preto. Ocupando apenas $3,7 \%$ do território estadual, a região apresenta uma das maiores densidades demográficas do Estado (117 hab./km2 em 2002). Os contrastes intra-regionais são acentuados: a menor densidade é encontrada em Luís Antônio (12 hab./km2); a maior corresponde a Ribeirão Preto (superior a 800 hab./km2) ${ }^{73}$.
\end{abstract}

Ou seja, a tal dicotomia capital-interior se tornou defasada em relação a uma regionalização vinculada à organização do espaço através de redes, ainda que essas redes não suprimam as assimetrias e hierarquias existentes entre cidades e regiões. 
Segundo Lefebvre, a superação da oposição "cidade-campo" se deu pelo processo de implosão-explosão das grandes metrópoles que produziram ações em outras cidades da rede urbana. Implosão, dada a mecanização do campo, que gerou um excedente populacional que fora absorvido pelas aglomerações urbanas, que também passaram a concentrar mais atividades e serviços. Explosão, porque as cidades passaram a se expandir e se alargar e porque os circuitos de produção e capitais foram reorganizados no território: houve uma disseminação de empresas pelos campos e indústrias, que migraram dos grandes centros para outros pontos da rede urbana, atualmente denominadas regiões metropolizadas e não-metropolizadas, atraindo para tais pontos ofertas de mão-de-obra. Do mesmo modo ocorreu com serviços e atividades até então concentrados e disponíveis apenas nas regiões metropolitanas. Assim, redistribuiu-se o que outrora estava concentrado para demais cidades e regiões, reorganizando estruturas regionais. O espaço urbano se definiu do mesmo modo enquanto fenômeno global. A capacidade revolucionária camponesa fora absorvida pelas práticas urbanas. Tomou-se forma uma espécie de colonização (ou "civilização") dos espaços pelos grandes centros de decisão, de informação, riqueza, saber e poder, feudalizando suas dependências, redefinindo a fronteira cidade-campo para periferia dominada e centro dominador ${ }^{74}$.

As relações entre as cidades da região, deste modo, não são geradas nem se encerram em um único território, ou apenas entre as cidades da região de Ribeirão Preto, mas acabam se articulando com outros territórios e estabelecendo vínculos de naturezas diversas, desenvolvendo uma ideia de rede, ou território descontínuo. A noção de rede permite a superação da ideia de exclusividade de um poder em relação a um dado território, o que resulta em uma série de relações de interdependência entre os pontos dessas redes. Quanto maior o número de pontos que se conectam a outro ponto, maior a relação de influência deste último. Ao transpor essa lógica para o território paulista, é possível notar que as regiões do estado estão conectadas com a capital paulista, de modo que esta acaba influenciando processos e dinâmicas das demais áreas do estado: algumas mais, outras menos, dependendo da intensidade das relações socioeconômicas com a capital. A figura 14 permite uma visualização da região de influência de Ribeirão Preto, com base em dados do Instituto Brasileiro de Geografia e Estatística, de 2007, articulada com os principais grandes centros metropolitanos (São Paulo, Belo Horizonte, Rio de Janeiro, Brasília), 

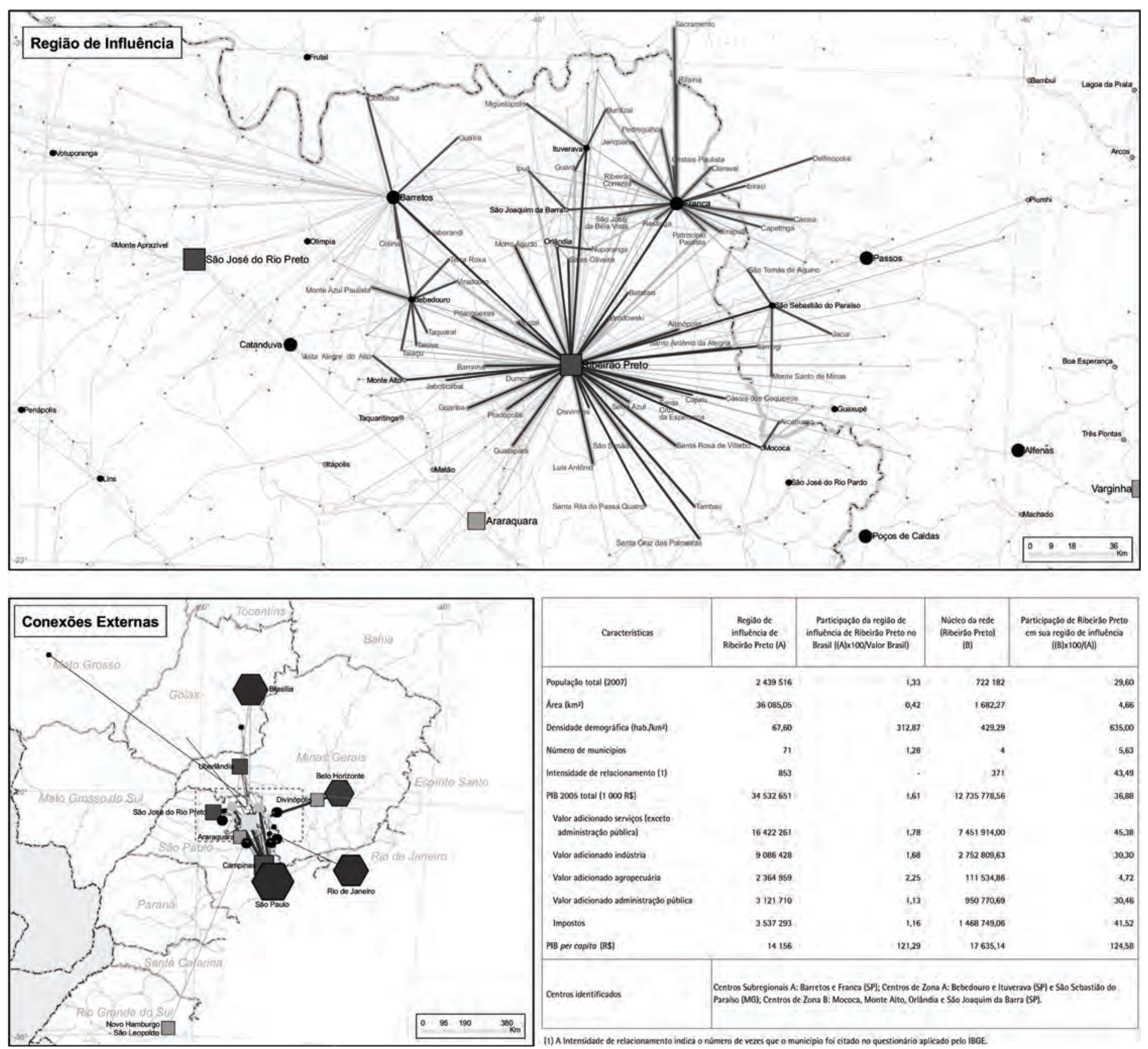

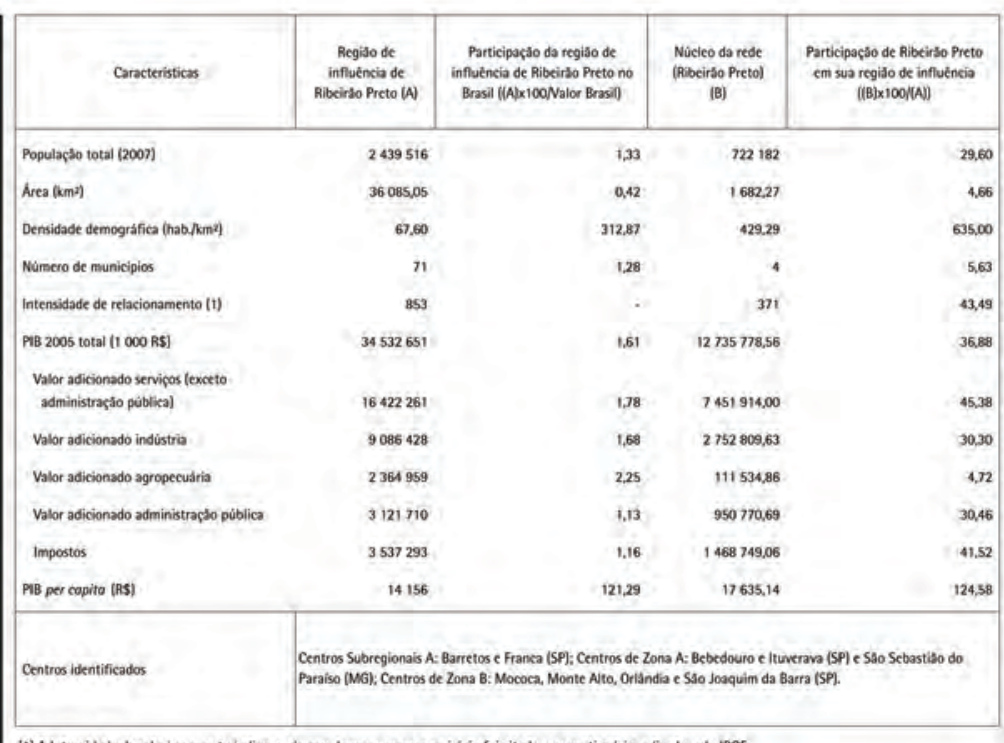

Figura 14-Região de influência regional e nacional de Ribeirão Preto.

Fonte: IBGE, Regiões de influência das cidades. Rio de Janeiro: IBGE, 2007.

70 GABRIEL PRATA 
com Goiânia, Cuiabá e Nova Hamburgo, para além de outras regiões, como a de Uberlândia, São José do Rio Preto, Araraquara e Campinas, revelando não apenas as relações socioeconômicas com as cidades de sua região administrativa, mas também com a região metropolitana de São Paulo, com outras cidades do interior paulista e de outros estados. Isso acaba tornando o território paulista bastante diverso. Porém a conexão não possui via de mão-única. Ao mesmo tempo em que uma cidade influencia, é influenciada. Tudo isso caracteriza um complexo de relações sobre o território, articulando atividades que escapam ao seu entorno imediato e buscam nexos distantes, revelando uma rede de circuitos espaciais de produção e círculos de cooperação que transpassam limites administrativos. Uma oscilação econômica ribeirão-pretana talvez não interfira com a mesma intensidade no cotidiano de Brasília, ou São Paulo, como irá interferir na de Sertãozinho, Pontal, Cajuru, ou Cravinhos, justamente pelo alto nível de interação que tais cidades possuem com Ribeirão Preto. E essas relações estão fortemente atreladas à produção agroindustrial da região.

A conformação inicial e posteriores reestruturações da região de Ribeirão Preto são resultados de processos decorrentes de estímulos externos à própria região. Tanto a busca por lugares de cultivo de café no século XIX, como a industrialização e, posteriormente, os investimentos e a atração de capitais financeiros constituíram processos externos que alteraram ou interferiram no processo de reestruturação e organização do território regional. Assim, é possível localizar a região de Ribeirão Preto em meio a diversos processos socioeconômicos, ao mesmo tempo em que tais processos transpassam a região com suas dinâmicas e temporalidades.

Sem dúvida, grande parte de tais processos está relacionada à capital paulista. São Paulo tem se afirmado cada vez mais enquanto cidade global, estabelecendo-se enquanto polo de influência na rede urbana (para além dos limites territoriais de administração). E é a partir dessa relação que a ideia de região metropolizada se baseia. A expansão urbana, os processos de urbanização, industrialização e financeirização da região de Ribeirão Preto, portanto, não podem ser vistos como processos isolados, exclusivos e originários na própria região. $\mathrm{O}$ processo de expansão urbana ribeirão-pretano tem como principal foco de origem, ou balizador, outros processos, decisões e problematizações geradas inicialmente por atores localizados na capital paulista. Existe uma dependência à capital que permite compreender a região de 
Ribeirão Preto enquanto extensão do território da metrópole em vários aspectos. Assim foi com a economia cafeeira no século XIX, balizada por atores localizados na capital, que definiu o território do estado; assim foi com a industrialização na segunda metade do século $X X$, através de processos de conformação de rede e a migração industrial da região metropolitana para outras regiões do estado; e assim foi com os processos de financeirização, a partir dos anos 1970. Deste modo, tanto a região metropolitana de São Paulo quanto a região de Ribeirão Preto correspondem a etapas distintas de um mesmo processo.

Assim, atualmente o estado de São Paulo se encontra em uma fase de urbanização completa, de modo que a questão é "imprimir aos espaços urbanos características da metrópole, porque muitas atividades, até então exclusivas da metrópole, necessitam ser reproduzidas fora dela para que a reprodução do capital em geral continue sua expansão"75. É possível observar isto através da presença cada vez mais intensa de grandes empresas imobiliárias, empresas de securitização, concessionárias, lojas de fast-food, shopping centers e franqueados, atores até então facilmente encontrados e restritos à região metropolitana, até mesmo, no ponto da arquitetura e do planejamento, a influência de planos urbanos, tipos de apartamentos, de edifícios e de condomínios. A presença de tais características no interior do estado é que permite considerar a região de Ribeirão Preto como região metropolizada (ver figura 15), uma vez que se constitui em um espaço metropolizado (no que diz respeito à magnitude e investimentos de capital, ao desenvolvimento de suas atividades de serviços com sua correlata concentração de "trabalho intelectual" ${ }^{\text {"e }}$ e com relação ao desenvolvimento de atividades de gestão e administração), ainda que distante fisicamente da metrópole ${ }^{77}$. Do ponto de vista visual, a região metropolizada e a metropolitana são evidentemente distintas, uma vez que em uma as cidades ainda possuem grandes lotes de produção agrícola entre as malhas urbanas, enquanto na outra as malhas das cidades já se encontram unidas. Entretanto a análise não deve ser levada apenas pelos aspectos físicos ou escalares.

A "Califórnia brasileira", como muitos autores definem a região de Ribeirão Preto, assim como muitas áreas urbanas do país, depois de três décadas de rigoroso crescimento econômico, passou a apresentar diversos sintomas de crise que afligem o homem contemporâneo, como desigualdades sociais, territoriais e econômicas que envenenam o cotidiano, tornam as pessoas mais individualistas, ignorando a luta rumo à
75. LENCIONI, 2004 apud. SCHIFFER, 2004, p.157.

76. O trabalho intelectual, ou imaterial, se refere a atividades intelectuais que qualificam subjetivamente as mercadorias, como trabalhos de criação, design, publicidade, marketing e demais atributos simbólicos, constituindo-se elementos centrais no processo de valorização das mercadorias (CAMARGO, S. Trabalho imaterial e produção cultural: a dialética do capitalismo tardio. São Paulo: Annablume, 2011).

77. LENCIONI, 2004 apud. SCHIFFER, 2004, p.157. 


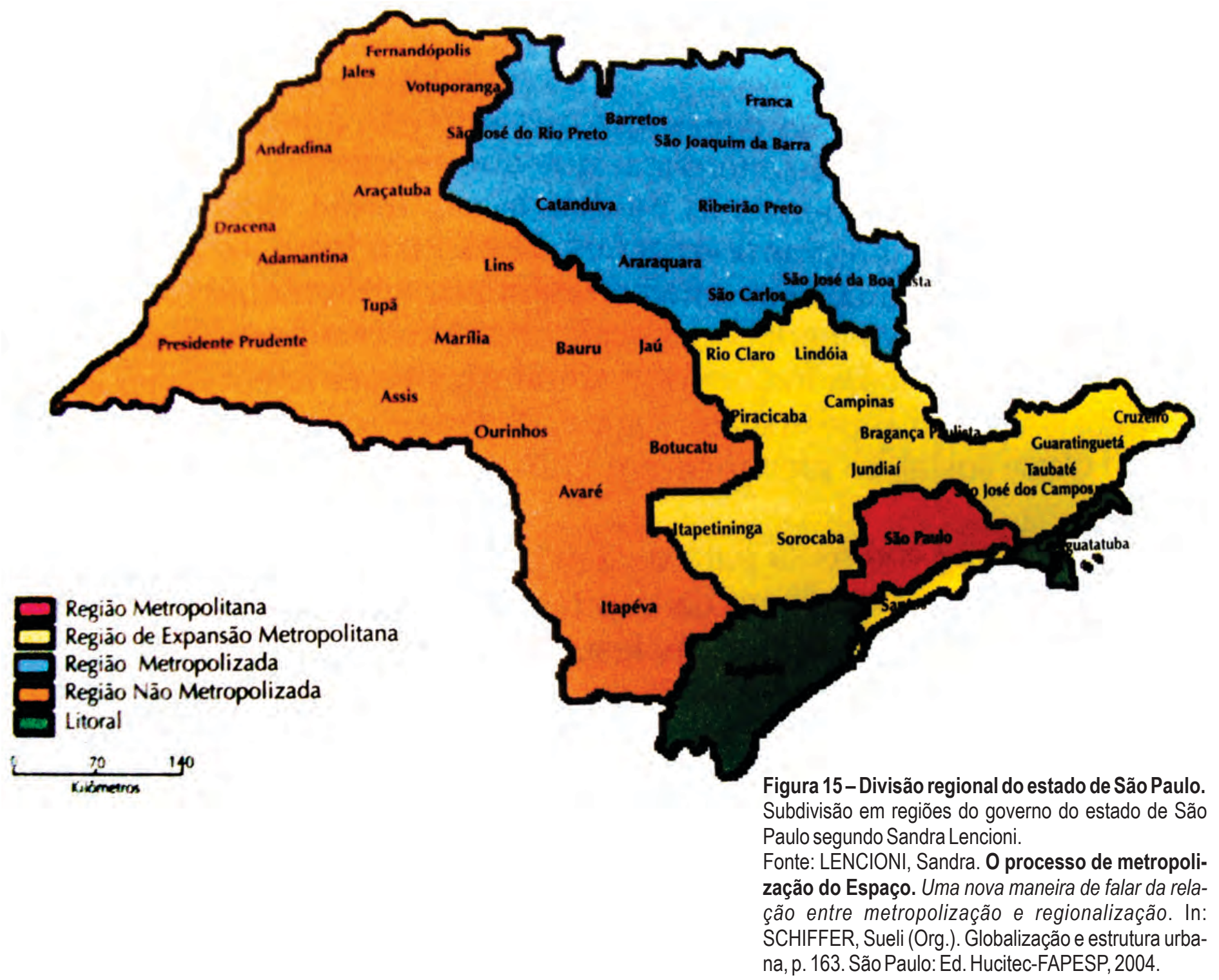


conquista da cidadania. O enfraquecimento econômico da região, não apenas durante a entressafra da cana-de-açúcar, aumentou o número de pessoas que passaram a viver às margens da sociedade. "A conjuntura de desigualdade social e econômica resultante do desenvolvimento dirigido por interesses exógenos à região impediu expressiva parte da população de ter acesso a bens de serviços essenciais à existência, o que tem originado pobreza e aumentado as formas de violência urbana"78. Comparados às grandes cidades, os níveis de violência são bastante inferiores, porém em termos absolutos, a região atingiu patamares preocupantes, como nos casos de roubos, furtos, assassinatos e acidentes de trânsito.

Todos os dias milhares de pessoas se deslocam entre as cidades da região de Ribeirão Preto. Nos horários de pico, ônibus lotados, grandes avenidas congestionadas. Moradores de rua, crimes, inseguranças, reprodução do modelo condominial e de lojas de fast-food. 0 cotidiano, os conflitos, a violência urbana, afazeres, necessidades, fetiches, os mercados enfim, tudo se abre e se torna acessível através da rede. Os deslocamentos de mercadorias, de trabalhadores e todos esses processos e redes de relações socioeconômicas se dão de maneira similar ao encontrado na grande São Paulo. De fato, a escala do fenômeno varia, gerando vantagens e desvantagens (níveis de poluição, oportunidades de emprego, disponibilidade e acesso a serviços e equipamentos culturais, modalidades de transporte público, congestionamentos, número e representatividade dos atores envolvidos). Porém a problemática urbana, os desafios e processos socioeconômicos são e tendem a ser os mesmos ${ }^{79}$.

Ao se analisar o processo de reestruturação produtiva no interior de São Paulo, há de se concordar com HARVEY (2011) quando aponta que os processos de urbanização e industrialização a partir dos anos 1970 sofreram uma transformação de escala em nível global, expandindo-se pela rede urbana para quaisquer municípios dispostos a absorver capitais excedentes e reinvestir lucros em uma rápida expansão.

\section{ELIAS, 2003, p.355.}

79. O desenvolvimento econômico na região se deu, sobretudo, às custas de um processo de degradação ambiental. Segundo ELIAS (2003), as transformações nas práticas e produção agrícolas, a expansão da monocultura, a instalação de indústrias metalúrgicas e o crescimento urbano espraiado e o volume crescente de lixo e esgoto provocaram danos a corpos d'água, ao solo, ao ar, comprometendo a qualidade de vida da população. Com relação aos índices de porcentagem da superfície coberta com mata nativa, apresentam-se inferiores aos analisados na capital paulista. O recomendado pela OMS é de $20 \%$, contudo as taxas flutuavam entre os municípios de $6 \%$ (em Ribeirão Preto) a 0,5\% (em Pradópolis) (ELIAS, 2003, p. 348). 



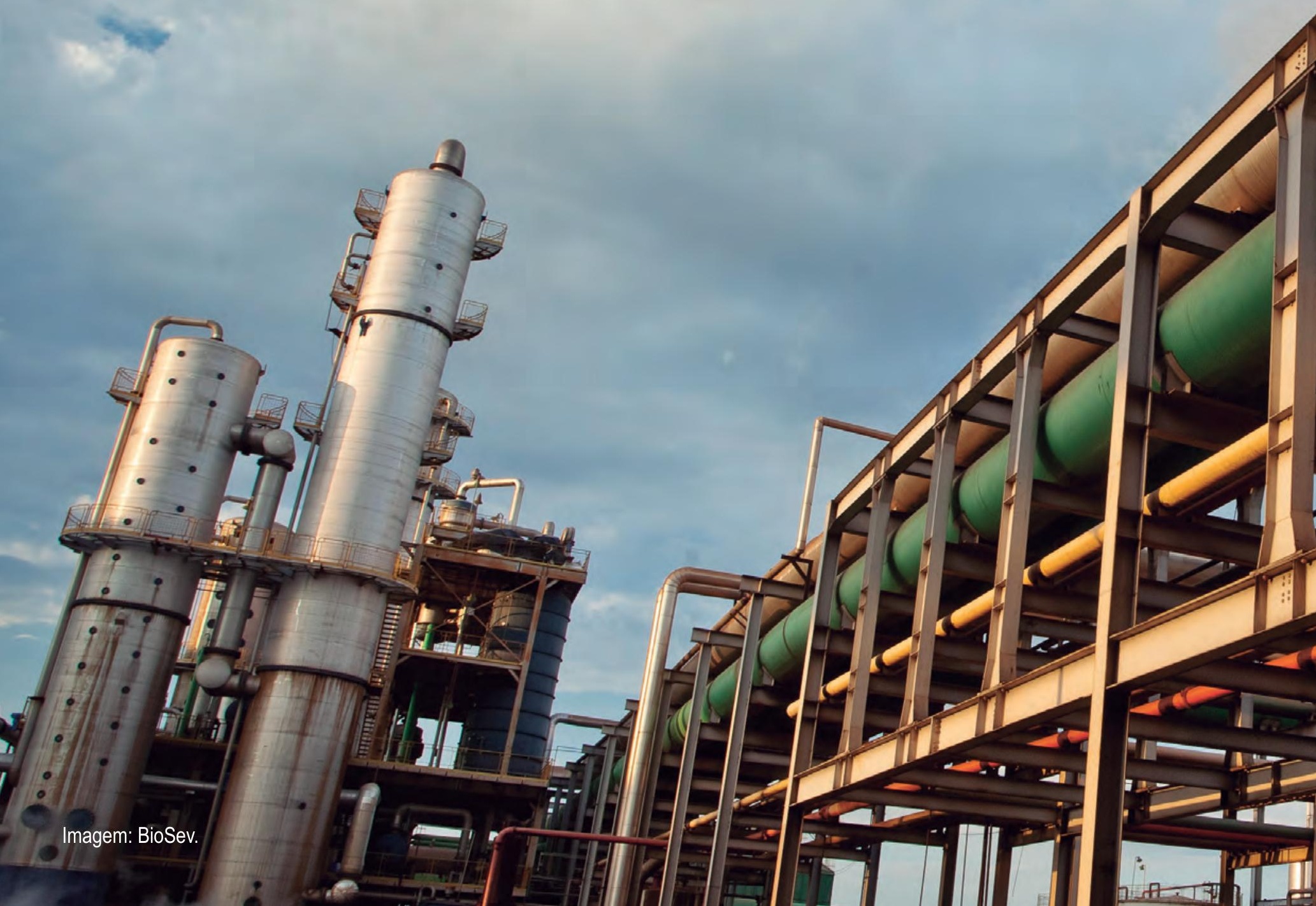


selod o ofnemsiontanad 

beneficiamento e bolsa beneficiame

.

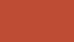

a

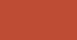

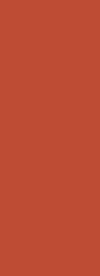
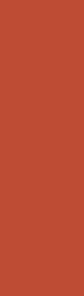
REESTRUTURAÇÕES NEOLIBERAIS
HARVEY (2011) ilustra que a evolução do capitalismo pode ser vista como um conjunto de inter-relações entre necessidades de evolução técnica e social para a acumulação do capital, compreendendo um conjunto de sete esferas: "tecnologias e formas de organização; relações sociais; arranjos institucionais e administrativos; processos de produção e de trabalho; relações com a natureza; reprodução da vida cotidiana e da espécie; e concepções mentais do mundo" ${ }^{\text {" }}$. Nenhuma delas é dominante e independente das demais: elas evoluem por conta própria, mas possuem inter-relações dinâmicas umas com as outras.

\begin{abstract}
Nenhuma esfera prevalece sobre as outras, mesmo quando existe dentro de cada uma a possibilidade de desenvolvimento autônomo (...). Cada uma das esferas está sujeita a uma renovação e transformação permanentes, tanto na interação com as outras quanto por meio de uma dinâmica interna que cria constantemente novidades nas questões humanas. As relações entre esferas não são casuais, mas dialeticamente interligadas pela circulação e acumulação do capital ${ }^{81}$.
\end{abstract}

Tal desenvolvimento desigual produz tensões e contradições, 81. Ibid., p. 108. o que o capital busca descobrir formas de explorá-los e manipu- 
lá-los, tanto para fraturar solidariedades de classes quanto para mercantilizar e canalizar em nichos de mercados as demandas associadas a tais conflitos ${ }^{82}$, tal como o processo de reestruturação produtiva ocorrida em Ribeirão Preto. A região se destacou enquanto importante exemplar das dinâmicas e processos de urbanização e organização territorial das últimas décadas, acumulando recursos técnicos e financeiros, aumentando a composição técnica e orgânica de seu território, transformando-se num dos principais polos mancha de produção agropecuária no Centro-Sul do país ${ }^{83}$, produzindo novas tecnologias, formas organizacionais, ocupacionais e espaciais. A reestruturação produtiva do setor primário concentrou a propriedade da terra e a diferenciou das parcelas que compõem a região - seja na alocação de investimentos ou nas relações de trabalho, territorializando o capital no campo, aumentando a concentração fundiária, oligopolizando o espaço agrário e especializando e industrializando suas produções -, principalmente a sucroalcooleira, a fim de realizar plenamente a atividade enquanto negócio financeiro, abastecendo mercados no exterior e produzindo etanol combustível para a frota veicular nacional.

As transformações foram bastante significativas nas relações mais diversas entre as sete esferas, alterando o espaço antigo e recriando o espaço no campo e na cidade, garantido pela diversidade e quantidade de fixos artificiais, fluxos e nexos presididos pelas cidades e produzidos no campo e fora da região de Ribeirão Preto. Aárea urbana também se reformulou a partir das "novas formas de realização da vida econômica e social”. O aprofundamento da divisão social e territorial do trabalho agrícola e sua especialização transformaram as relações entre as cidades da região, ampliando as diferenças entre elas, dado o nível de organização e especialização que cada uma obteve para atender a demandas econômicas, resultando em uma total remodelação do território e sistema urbanos, com forte atuação do Estado através de políticas públicas de órgãos regulamentadores do setor, conforme visto com o Instituto do Açúcar e do Álcool.

Sem dúvidas, o IAA correspondeu a um dos principais braços do Estado na mecanização da agricultura, na industrialização e na urbanização brasileiras, principalmente no estado de São Paulo e na agroindústria sucroalcooleira. Era através das políticas públicas de investimento no setor agrícola que o Estado reestruturava as bases para a acumulação capitalista industrial e sua reprodução no nível das próprias empresas, tornando-as as unidades mais rentáveis do conjunto da eco-

82. Ibid., p. 110.

83. ELIAS, 2003. 
84. Dados extraídos do site do PMGCA-UFSCar. Disponível em: <http://pmgca.dbv.cca.ufscar.br/>. Acesso em: 11/06/2014

85. "A gestão do risco rural realiza-se em duas frentes. Antes de iniciar o cultivo, o agricultor conta com 0 Zoneamento Agrícola de Risco Climático. Essa ferramenta tecnológica indica o melhor período para se plantar em cada município do País, conforme a análise histórica do comportamento do clima. E, para se proteger dos prejuízos causados por eventos climáticos adversos, o produtor pode contratar o Seguro Rural com parte do prêmio subsidiado pelo ministério. As políticas de mobilização de recursos viabilizam os ciclos do plantio. O homem do campo tem acesso a linhas de crédito para custeio, investimento e comercialização. Vários programas financiam diversas necessidades dos produtores, desde a compra de insumos até a construção de armazéns". (Extraído do sítio do Ministério da Agricultura. Disponível em: $<$ http://www.agricultura.gov.br/politica-agricola>. Acesso: 12/06/2014). nomia. Com a adoção de um modelo neoliberal e com a liberação das exportações, o setor deixou de ser regulamentado pelo Estado, assim como o controle dos preços do açúcar e do álcool, em virtude da reversão do preço do petróleo e do desabastecimento de álcool combustível no país, causado pelo aumento do consumo e pela influência política dos usineiros. O IAA passou a ser visto como um modelo de administração pouco econômico, sendo extinto em 1990, com o programa de reformulação da máquina estatal no período Collor. O setor sucroalcooleiro passou a ser amparado financeiramente pelo BNDES (Banco Nacional de Desenvolvimento) e pelo FAT (Fundo de Amparo ao Trabalhador).

No que tange às pesquisas, com a extinção do PLANALSUCAR, o trabalho de pesquisa fora absorvido pela RIDESA (Rede Interinstitucional de Desenvolvimento do Setor Sucroalcooleiro), grupo composto por 10 universidades que deram continuidade ao programa de criação de novas variedades de cana-de-açúcar e ampliaram-no, para atender à crescente demanda do setor, inclusive com variedades que permitem a ampliação do período de colheita e com a criação de variedades mais precoces. As universidades componentes do grupo são todas federais (UFPI, UFRPE, UFAL, UFS, UFV, UFRRJ, UFSCar, UFPR, UFGO e UFMT) e estão todas localizadas em estados em que existe realização intensa e expansão da produção canavieira, constituindo uma rede de conhecimento e informações tecnológicas e acadêmicas voltadas para a produção agroindustrial sucroalcooleira em escala nacional ${ }^{84}$. Deste modo, a produção de conhecimento e de tecnologias também constitui uma articulação bastante forte entre o Estado e a reprodução no setor em questão.

Apesar da desregulamentação do mercado do álcool, as relações do Estado com o setor ainda se mantêm muito sólidas através de investimentos (educação, tecnologia, linhas de crédito, políticas e programas voltados para gestão do risco da produção, do crédito e da comercialização, através do Ministério da Agricultura $\left.{ }^{85}\right)$, regulamentações para promoção e uso de tecnologias a álcool no território (como a regulamentação para produção de automóveis com a tecnologia flexfuel) e medidas regulatórias de adição de álcool à gasolina. Ainda que não com o mesmo rigor e controle estatal que ocorreu com o Proálcool, as políticas econômicas ainda assim permitem beneficiar ou não o setor sucroalcooleiro direta e indiretamente. Combinando com as atuais políticas de incentivo à indústria automobilística nacional, observou-se que 
a redução de IPIs dos automóveis flex possibilitou um aumento da produção de etanol, permitindo que as usinas aumentassem sua produção, sem que o preço do produto diminuísse. Afinal, quanto maior a frota de veículos nacional, maior a demanda por etanol e, consequentemente, mais amplo o mercado para as usinas. Estabelecia-se um elo entre agronegócio, complexos agroindustriais, mercado, Estado e mobilidade urbana, destacando-se o aumento considerável tanto da frota particular quanto dos congestionamentos em cidades da região metropolizada, independentemente de suas escalas.

A partir do governo Quércia (1987-1990), com o Estado regulando o complexo sucroalcooleiro completamente em benefício do setor e não como atividade que limitaria ou direcionaria as atividades sucroalcooleiras, notou-se "a expansão dos grupos produtores tradicionais, com maior concentração da produção de açúcar e álcool, bem como da posse da terra agricultável do estado" ${ }^{86}$. No que tange a uma análise contextual neste período, há de se concordar com MONBEIG ao afirmar que

\begin{abstract}
A riqueza fundiária, a produção agrícola e os meios de transporte [passaram a estar] reunidos sob as mesmas mãos (...). A agricultura era o fundamento da riqueza (...). Posteriormente, a direção dos negócios foi (...) sendo separada das atividades agrícolas. Hoje os nomes dos diretores (...) que se encontram nos conselhos de administração dos bancos e das companhias de seguro não são mais citados como de grandes fazendeiros ${ }^{87}$.
\end{abstract}

A figura do fazendeiro foi sendo paulatinamente substituída pela do homem de negócios, e as relações de dependência do sitiante para com o fazendeiro se alteraram para relações entre pequenos proprietários e grandes empresários ou industriais. Já as relações entre latifundiários e demais proprietários, bem como sua relação com a produção agropecuária passou a receber definições provindas da esfera dos negócios.

Durante os anos 1990, o discurso neoliberal já se consolidava enquanto alternativa às crises econômicas mundiais e ao modelo de governo mais alinhado às novas exigências da nova ordem mundial, com promessas de modernização e de um novo mundo da globalização, mascarando os reais interesses das altas finanças e da lógica financeira de acumulação. Assim, no setor sucroalcooleiro, já desprovido de regulações estatais, a iniciativa privada se organizou e fundou a
86. FERREIRAeALVES, 2009, p. 11. 87. MONBEIG, 1984, p. 240. 
Bolsa Brasileira de Álcool Ltda. - BBA -, em 1999, para controlar a comercialização e a produção de todas as 170 usinas associadas, correspondendo a $85 \%$ do álcool produzido na região Centro-Sul.

\begin{abstract}
Os novos sistemas de comunicações permitiram a organização rigorosa da cadeia produtiva de mercadorias no espaço global. (...) Acima de tudo, uma nova arquitetura financeira global foi criada para facilitar a circulação do fluxo internacional de capital-dinheiro líquido para onde fosse usado de modo mais rentável [o processo de internacionalização das usinas sucroalcooleiras brasileiras após os anos 1980 aponta para o direcionamento do capital de grandes empresas mundiais aos setores produtivos nacionais. Em um levantamento de dados da Única, várias usinas estão articuladas a grandes holdings internacionais]. A desregulamentação das finanças, que começou nos anos 1970 , acelerou-se depois de 1986 e tornou-se irrefreável na década de $1990^{88}$.
\end{abstract}

Em 1997, foi criada a União da Indústria de Cana-de-Açúcar (UNICA), a maior organização representativa do setor de açúcar e bioetanol do Brasil. Resultante da fusão de diversas organizações setoriais do estado de São Paulo, após a desregulamentação do setor no País, a associação passou a se expressar e a atuar em sintonia com os interesses dos produtores de açúcar, etanol e bioeletricidade, tanto no Brasil como ao redor do mundo. Atualmente, as mais de 130 companhias associadas à UNICA eram responsáveis por mais de $50 \%$ do etanol e $60 \%$ do açúcar produzidos no Brasil. Dentre as atuantes em território paulista, destacam-se a BioSev (ramo da LD Commodities), Bunge, Odebrecht Agroindustrial (ramo do conglomerado brasileiro que atua em grande partes do mundo nas áreas de engenharia, construção, produtos petroquímicos e químicos), Raizen (fruto da junção de negócios entre Shell e Cosan), Santa Adélia, Guarani, São Domingos, Viralcool, São Martinho, Pedra Agroindustrial e Copersucar S.A. (grupo transnacional criado em 2008, que passou a controlar boa parte da comercialização de açúcar no mundo, incorporando a antiga Cooperativa de Produtores de Cana-de-Açúcar, Açúcar e Álcool do Estado de São Paulo, criada em 1959).

Em maio de 1999, foi criada a Bolsa Brasileira de Álcool Ltda., reunindo cerca de 170 usinas a fim de controlar a comercialização de aproximadamente $85 \%$ do álcool produzido na região centro-sul do país, vendendo o álcool e administrando a oferta do produto, visando à recuperação da margem de lucro das usinas e, consequentemente, do 
próprio setor. Sua criação foi considerada pelo Sindicato Varejista dos Derivados de Petróleo, na época, uma das responsáveis pelo aumento do preço dos combustíveis.

A admissão do Brasil no circuito internacional de valorização financeira era mais do que almejada durante a década de 1990 e foi possível através da renegociação da dívida externa e sua securitização (reabrindo fontes externas de financiamentos e definindo um contexto de completa submissão a interesses externos), à criação de títulos da dívida brasileira em mercados internacionais, à estabilização monetária da economia brasileira (com o Plano Real, em 1994), e à desregulamentação do mercado financeiro ${ }^{89}$ pela direção do Banco Central. Esta última ação promoveu a abertura financeira do país, alicerçada sobre reformas previdenciária, tributária e financeira, e pela autonomia do Banco Central, que, através dos tributos, retirava parcela da renda real da sociedade e a transferia para a esfera da valorização financeira, assegurando o rendimento dos títulos (capital fictício) que produzia.

Com todas essas alterações e desdobramentos, o país encontrou uma série de efeitos indesejados internamente, que precisariam ser sanados para potencializar efetivamente a atração de capitais externos. Novamente, com a Lei de Responsabilidade Fiscal de 2000, negociada por Fernando Henrique Cardoso com o FMI durante a crise de desvalorização do Real, priorizaram-se as relações financeiras externas em detrimento da viabilização de investimentos e políticas públicas. O governo Lula apenas preencheu as lacunas restantes, necessárias para dar continuidade ao processo, como ajustes na reforma tributária, a aprovação da Lei de Falências, em 2005, o aumento da Desvinculação de Recursos da União (DRU), e políticas compensatórias de renda, para poder contribuir de certa forma com as políticas sociais que estavam na pauta do partido. Independente de disputas partidárias internas, o Estado tem se reestruturado para tornar 0 país mais adequado à esfera econômico-financeira mundial ${ }^{90}$.

No país todo foram verificadas mudanças tanto na escala de metropolização quanto na complexidade do fenômeno urbano sobre o território, evidenciadas pela emergência de novos conjuntos polarizadores de crescimento populacional e de concentração de atividades, serviços e capitais urbanos para além das grandes metrópoles, que até então eram as que concentravam e polarizavam o controle das atividades produtivas do capital. Constituía-se assim um novo cenário territorial, articulando regiões metropolitanas e não metropolitanas; grandes e
89. 0 modo regulamentado do capitalismo do período anterior não condizia com um regime de acumulação sob a égide da valorização financeira. Volátil, desconectado da produção efetiva de riqueza material da sociedade, rentista e necessitante de curtos-prazos, o capital financeiro necessita de liberdade de movimentação e não de regulamentos, normas e regras que limitem sua veloz valorização.

90. A credibilidade que um país precisa passar para investidores externos é necessária para manter sua vulnerabilidade econômica - risco-Brasil, desempenho da moeda doméstica, a cotação do C-Bond (títulos da dívida brasileira no mercado) -, e não a estabilidade e sustentabilidade de seu desenvolvimento socioeconômico. Prioriza-se 0 crescimento econômico em detrimento do desenvolvimento social. Tal credibilidade perante o mercado permite a atração de capital exterior. Tanto ela quanto a vulnerabilidade são necessárias para a valorização de capitais especulativos que dominam os processos de acumulação, tal como crises, turbulências e variações bruscas no cenário econômico mundial, produzindo uma engorda do capital especulativo no mundo. 
91. A paisagem geográfica assim se configura um espaço de tensões entre economias de centralização e de lucros potencialmente maiores previstos com a descentralização e com a dispersão (HARVEY, 2011). pequenas cidades organizadas em rede. Assim sendo, é de extrema importância ressaltar que os processos que ocorreram (como a industrialização seguida pela metropolização) e ainda ocorrem na região de Ribeirão Preto, e seu caráter polarizador de desenvolvimento regional são consequências de um processo de urbanização que transpassa o território administrativo da região. O processo de metropolização do espaço, originado na capital paulista, também conseguiu se expandir para grandes áreas do interior do estado, contribuindo para a reestruturação da produção, configurando uma rede de cidades no território paulista. Tal rede definiu e incorporou cidades das mais variadas escalas, reconhecendo suas relações de interdependência a centros urbanos maiores, constituindo constelações de núcleos e aglomerados urbanos no território, integrados em uma rede urbana com metrópoles e demais cidades, articuladas através de um sistema de comunicações físicas e virtuais.

Desse modo, esse sistema urbano organizado em rede permitiu aos excedentes (e ao próprio capital) transpassarem barreiras administrativas, até mesmo de Estados, através de uma série de inovações tecnológicas que diminuíram limitações impostas por grandes distâncias, minimizando problemas de mobilidade geográfica do capitalismo, não permanecendo mais ancorados a um lugar específico. Porém a aglomeração permaneceu essencial para a diminuição de gastos com transportes, visando ao lucro máximo e reproduzindo arranjos produtivos pelo território, tais como os complexos agroindustriais ${ }^{91}$.

Inclusive, o termo "arranjos produtivos locais" se tornou mais recorrente no Brasil a partir dos anos 1990, como alternativa de crescimento econômico relacionado ao capitalismo mundial. A produção, circulação e veiculação de produtos, ideias, informações e capitais alteram tanto o território quanto o comércio internacional. Utilizando-se da reestruturação através de arranjos produtivos, o agronegócio constituiu, no século XXI, importante forma do capital de reconquistar o espaço geográfico para manifestação e reprodução de suas práticas, relações sociais, de produção e formas de poder. A produção agrícola passou a ser negociada enquanto commodity, através de cotações em bolsas de valores, que passaram a definir o preço e a comercialização de matérias-primas e produtos agrícolas, e se ampliou a reprodução do capital no setor, trazendo desdobramentos para o território urbano. A cidade se tornou o locus das atividades e transações relativas ao agronegócio incluindo estabelecimentos de setores financeiros e serviços especiali- 
zados -, tornando mais indissociável a relação local-global e promovendo ainda mais a divisão territorial do trabalho.

As transformações operadas no setor produtivo estão diretamente relacionadas à dominação financeira do processo de acumulação. Em última instância, buscam conferir ao capital "a flexibilidade necessária para que [o próprio capital] aproveite as oportunidades de acumulação onde quer que elas se encontrem (no setor produtivo, no setor financeiro, nos negócios de Estado)",92, gerando, consequentemente, conflitos nas relações de trabalho ${ }^{93}$. No que tange à agroindústria, trazem uma série de conflitos específicos para o debate, como a exploração da força de trabalho nos canaviais, por conta de maior produtividade das usinas; a reforma agrária; a produção alimentar e a agricultura familiar - importantes conflitos a serem colocados em questão, pois correspondem a processos inerentes ao contexto e cotidiano urbanos.

Conforme visto, a produção agroindustrial sucroalcooleira está baseada na exploração do trabalho por produção e pagamento muito baixo. Ao serem analisadas, as tabelas 5 e 6 permitem destacar que a produção de cana-de-açúcar destinada à indústria tem aumentado a cada ano nas regiões produtoras, incluindo a de Ribeirão Preto. A quantidade de cana-de-açúcar produzida em 2001 no Brasil foi de 344,29 mil toneladas. Tal número aumentou para 671,40 mil toneladas em 2009, apresentando uma variação de 95\%. A produtividade média (medida pela razão tonelada por hectare) também teve um aumento de 13,6\% (de 69,4 t/ha, em 2001, para 78,9 t/ha, em 2009) ${ }^{94}$, o que indica que a exploração dos trabalhadores também aumentou na mesma proporção. Com a inserção do corte mecânico com maior intensidade a partir de 2007, foram fechados cerca de 40 mil postos de trabalho entre 2007 e 2011 (alcançando 70\% das usinas e 20\% dos fornecedores paulistas na safra de $2010 / 11)^{95}$, o que fez com que os cortadores remanescentes passassem então a competir com a produtividade das máquinas, sob ameaças de demissão ${ }^{96}$.

Apesar da conquista de diretos trabalhistas, nos anos 1990, com o emprego crescente de máquinas colheitadeiras, a exploração dos cortadores se tornou mais intensa. A rotatividade da mão-de-obra neste setor é bastante alta: um cortador de cana dificilmente consegue durar mais do que 15 anos no trabalho. Deste modo, tais capitais necessitam de trabalhadores jovens e cheios de energia para o processo pro-
92. PAULANI, 2008, p.123.

93. As alterações afetaram em grande parte a base de todo o processo de acumulação: a relação de trabalho. A terceirização, o contrato por tempo parcial e o trabalhador autônomo ganharam relevância como forma de preenchimento de poros de jornadas de trabalho, assim como novas estratégias empresariais passaram a visar o aumento da produtividade utilizando-se de estratégias tais como, por exemplo, o toyotismo (que busca reduzir gastos com gerências intermediárias, desmantelando a possibilidade dos trabalhadores se enxergarem enquanto classe, aproveitando o valor de uso da força de trabalho em sua totalidade). As empresas redefiniram a organização, contratação e demissão de seu pessoal na mesma velocidade em que as necessidades foram geradas com a dinâmica do capital financeiro (PAULANI, 2008).zindo uma engorda do capital especulativo no mundo.

\section{OS CONFLITOS NAS RELAÇÕES DE TRABALHO}

94. Dados extraídos de: DEPARTAMENTO INTERSINDICAL DE ESTATÍSTICA E ESTUDOS SOCIOECONÔMICOS, Estatísticas do meio rural, p.252, ed. 4, Ministério do Desenvolvimento Agrário. Brasília, 2011.

95. LIMA, E. S. Mais máquinas, mesma exploração. Brasil de fato. 13 de jun. 2011. Disponível em: <http://www.brasildefato.com.br/node/6578> Data de acesso: 09 de mai. 2014.

96. Após uma viagem para coletar dados em instituições em Ribeirão Preto, foi encontrado em um ônibus um grupo de homens que estavam migrando de Ribeirão Preto para São Carlos. Em uma conversa informal, disseram ser trabalhadores da região e de outros estados do país, principalmente do norte de Minas Gerais, sul da Bahia e de outros estados nordestinos, e que estavam em Ribeirão e nos complexos agroindustriais de Sertãozinho à procura de empregos. Haviam sido atraídos pelas oportunidades que as cidades ofereciam e divulgavam. Porém foram surpreendidos pela exigência de maior qualificação da mão-de-obra. Por não conseguirem nas cidades da região de Ribeirão Preto, foram obrigados a buscar ou por outros empregos em outros setores, ou migrarem para outras cidades. Optaram por se dirigirem a São Carlos em busca de trabalho na indústria ou na construção civil. Segundo um dos trabalhadores, caso obtivessem insu- 
Área Plantada com cana-de-açúcar (ha), 1980 - 2011

\begin{tabular}{|c|c|c|c|c|c|c|c|c|}
\hline ESTADO/SAFRA & 1980 & 1985 & 1990 & 1995 & 2000 & 2005 & 2010 & 2011 \\
\hline Acre & 832 & 329 & 1.538 & 659 & 220 & 798 & 2.769 & 2.654 \\
\hline Alagoas & 349.059 & 496.709 & 561.217 & 449.746 & 461.912 & 406.788 & 434.370 & 434.684 \\
\hline Amapá & 47 & 41 & 15 & 15 & 68 & 75 & 130 & 130 \\
\hline Amazonas & 690 & 1.208 & 2.389 & 1.654 & 4.168 & 5.756 & 5.407 & 5.211 \\
\hline Bahia & 76.958 & 84.879 & 80.302 & 76.880 & 92.060 & 92.947 & 96.743 & 116.171 \\
\hline Ceará & 54.508 & 45244 & 63.600 & 43.456 & 34.535 & 35.098 & 43.024 & 41.370 \\
\hline Distrito Federal & 812 & 750 & 0 & 271 & 243 & 498 & 923 & 883 \\
\hline Espirito Santo & 30.385 & 48.934 & 43.232 & 40.258 & 43.914 & 64.373 & 81.393 & 76.488 \\
\hline Goiás & 28.013 & 96.015 & 106.826 & 115.073 & 139.186 & 200.048 & 578.666 & 697.541 \\
\hline Maranhão & 23.667 & 24.061 & 37.374 & 24.514 & 19.912 & 31.728 & 50.477 & 48.565 \\
\hline Mato Grosso & 8.704 & 30.192 & 65.034 & 98.906 & 135.029 & 205.961 & 212.498 & 226.993 \\
\hline Mato Grosso do Sul & 11.976 & 50.705 & 67.921 & 75.315 & 98.958 & 136.803 & 399.408 & 495.821 \\
\hline Minas Gerais & 222.295 & 317.765 & 301.710 & 267.571 & 292.571 & 349.112 & 746.527 & 831.329 \\
\hline Pará & 7.473 & 3753 & 7.084 & 8.018 & 8.064 & 9952 & 10.897 & 12.592 \\
\hline Paraiba & 108.310 & 177.131 & 160.294 & 152.435 & 93.055 & 105.403 & 123.691 & 118.097 \\
\hline Paraná & 59.887 & 147.618 & 159.420 & 255.767 & 327.165 & 404.520 & 625.885 & 641.765 \\
\hline Pernambuco & 345.285 & 413.533 & 473.726 & 471.272 & 359.662 & 368.188 & 361.937 & 345.416 \\
\hline Piaui & 13.529 & 11.563 & 19.360 & 15.254 & 7.241 & 9.966 & 12.841 & 15.194 \\
\hline Rio de Janeiro & 201.791 & 221.175 & 206.786 & 161.787 & 158.824 & 168.279 & 133.286 & 105.091 \\
\hline Rio Grande do Norte & 36.337 & 52.724 & 59.959 & 53.723 & 43.380 & 53.940 & 65.326 & 59.463 \\
\hline Rio Grande do Sul & 49.523 & 61.790 & 31.598 & 27.127 & 32.876 & 32.570 & 35.970 & 32.694 \\
\hline Rondônia & 1.623 & 1749 & 462 & 393 & 410 & 700 & 3.824 & 3.767 \\
\hline Roraima & 3 & 70 & 0 & 0 & 361 & 548 & 563 & 564 \\
\hline Sảo Paulo & 1.088 .480 & 1.734 .895 & 1.811 .980 & 2.258 .900 & 2.484 .790 & 3.084 .752 & 5.071 .205 & 5.216 .491 \\
\hline Santa Catarina & 23.862 & 25.203 & 16.388 & 8.976 & 16.439 & 16.714 & 9.528 & 11.129 \\
\hline Sergipe & 22.001 & 26.511 & 38.104 & 24.808 & 21.208 & 26.867 & 46.665 & 50.988 \\
\hline Tocantins & 2464 & 10.311 & 5.980 & 5.503 & 3.590 & 2767 & 10.803 & 25.524 \\
\hline Região Centro-Sul & 1.725 .728 & 2.735 .042 & 2.810 .895 & 3.309 .951 & 3.729 .995 & 4.663 .630 & 7.895 .289 & 8.336 .225 \\
\hline Região Norte-Nordeste & 1.042 .786 & 1.349 .816 & 1.511 .404 & 1.328 .330 & 1.149 .846 & 1.151 .521 & $1,269.467$ & 1.280 .390 \\
\hline Brasil & 2.768 .514 & 4.084 .858 & 4.322 .299 & 4.638 .281 & 4.879 .841 & 5.815 .151 & 9.164 .756 & 9.616 .615 \\
\hline
\end{tabular}

Tabela 5-Área plantada com cana-de-açúcar (ha) no Brasil, 1980-2011. Fonte: Elaborada pela UNICA a partir de informações do Instituto Brasileiro de Geografia e Estatística-IBGE.

Disponível em: <http://www.unicadata.com.br/historico-de-areaibge.php?idMn=33\&tipoHistorico=5>. Acessado em jun. 2015. 
HISTÓRICO DE PRODUÇÃO CANA MOÍDA, AÇÚCAR, ÁLCOOL ANIDRO E ETANOL DO ESTADO DE SÃO PAULO

\begin{tabular}{|c|c|c|c|c|c|}
\hline Safra & Cana (t) & Açucar(t) & Álcool Anidro $\left(\mathrm{m}^{3}\right)$ & Etanol $\left(m^{3}\right)$ & Total Álcool $\left(\mathrm{m}^{3}\right)$ \\
\hline 20122013 & 329.922 .736 & 23.289 .350 & 5.600 .834 & 6.235 .223 & 11.836 .057 \\
\hline 20112012 & 304.229 .853 & 21.067 .955 & 4.755 .181 & 6.844 .455 & 11.599 .636 \\
\hline 20102011 & 359.000 .352 & 23.443 .503 & 5.098 .668 & 10.219 .670 & 15.318 .338 \\
\hline 20092010 & 364.794 .560 & 20.990 .556 & 4.306 .166 & 10.728 .108 & 15.034 .274 \\
\hline 20082009 & 346.292 .970 & 19.675 .290 & 6.006 .719 & 10.715 .759 & 16.722 .478 \\
\hline 20072008 & 296.313 .957 & 19.107.894 & 4.946 .431 & 8.398 .776 & 13.345 .207 \\
\hline 20062007 & 261.708 .737 & 19.177 .783 & 5.299 .431 & 5.630 .685 & 10.930 .116 \\
\hline 20052006 & 242.828 .824 & 16.763 .391 & 5.422 .510 & 4.522 .407 & 9.944 .917 \\
\hline 20042005 & 230.310 .237 & 16.516 .346 & 5.320 .973 & 3.782 .967 & 9.103 .940 \\
\hline 20032004 & 207.572 .538 & 15.171 .854 & 5.934 .721 & 2.872 .221 & 8.806 .942 \\
\hline 20022003 & 190.627.892 & 14.183 .370 & 4.589 .574 & 3.099 .799 & 7.689.373 \\
\hline 20012002 & 176.574 .250 & 12.350 .253 & 4.254 .838 & 2.879 .691 & 7.134 .529 \\
\hline 20002001 & 148.256 .436 & 9.675 .481 & 3.555 .033 & 2.884 .080 & 6.439 .113 \\
\hline 19992000 & 194.179 .485 & 12.585 .686 & 3.550 .154 & 4.456 .881 & 8.007 .035 \\
\hline 19981999 & 199.521 .253 & 11.827 .465 & 3.392 .040 & 5.697 .875 & 9.089 .915 \\
\hline
\end{tabular}

Tabela 6 - Histórico da produção total sucroalcooleira do Estado (1998-2012).

Fonte: Unica - União da Agroindústria Canavieira do Estado de São Paulo. Disponível em: <http://www.energia.sp.gov.br/portal.php/historico> . Acessado em jun. 2015. 
cesso, dariam continuidade ao deslocamento até que chegassem a São Paulo. Neste relato, fica evidente o forte papel de aglomeração que Ribeirão Preto possui e São Paulo ainda como referência de um paraíso de oportunidades de trabalho e enriquecimento.

97. Muito se questiona sobre o que leva os trabalhadores a se submeterem a processos de tamanha exploração. SILVA (2001) destaca a noção de exclusão-inclusão precária, partindo da constatação de essas pessoas constituírem parcela de uma população de excluídos, que não encontraram melhores condições de trabalho e de vida em seus locais de origem e migram para outras regiões à procura de emprego e renda. Dada sua baixa qualificação, são reinseridas através de trabalhos precários (frequentemente encontrados no campo e na construção civil). Não é de se espantar que a maior parte dos cortadores de cana é formada por negros, pardos e provindos de regiões bastante pobres do território nacional.

98. O levante de Guariba em 1984 citado anteriormente, por exemplo, teve pouquíssima participação dos sindicatos locais, sendo organizada e realizada pelos próprios trabalhadores.

99. VERAS, D. Convenções e acordos coletivos. Florianópolis, janeiro/2007. Disponível em: $<$ https://sites.google.com/site/dauroveras/convencoes_c ana>. Acesso em 04/06/2014 dutivo. Segundo SILVA (2010), no período de 2004 a 2007, foram registradas 21 mortes nos canaviais, supostamente causadas por birola, denominação dos próprios trabalhadores ao excesso de esforço e à overdose de trabalho, fora as condições precárias de nutrição, geradas pelos baixos salários (que impedem o acesso a melhor alimentação), calor excessivo no local de trabalho e elevado consumo de energia durante o expediente. Além disso, o aumento da produtividade influencia diretamente na saúde do trabalhador, que passa a ser exigido mais e mais através de imposição de médias (quantidades de cana cortada ao dia). Fato que também chama a atenção é o consumo de drogas entre os cortadores de cana, mais precisamente o crack, a fim de aumentar os níveis de produtividade ${ }^{97}$.

Ainda que com todas essas adversidades e as frequentes violações de direitos, bem como a exigência de alta produtividade da mãode-obra, os cortadores de cana estão entre os poucos segmentos de trabalhadores rurais que conseguem conquistar acordos coletivos nem sempre vinculados a sindicatos ${ }^{98}$. Aliás, em muitos casos, sindicatos se encontraram pareados a interesses de usineiros, como por exemplo em 2006, quando a Usina Alta Mogiana, de São Joaquim da Barra - SP, e quatro sindicatos de trabalhadores rurais de municípios paulistas (São José da Bela Vista, São Joaquim da Barra, Guará e Ipuã) foram alvos de ação civil pública do Ministério Público do Trabalho por fecharem acordos coletivos que eliminavam direitos trabalhistas (VERAS, 2007) ${ }^{99}$.

Mas as consequências do trabalho forçado não param por aí. Na região de Ribeirão Preto existe uma população de mutilados, em decorrência do corte manual da cana-de-açúcar e uma ainda maior de trabalhadores impossibilitados de trabalhar devido a dores e cãibras pelo corpo (SILVA, 2006). Em muitos casos, acabam não recebendo aposentadoria, pois laudos médicos alegam que ainda podem trabaIhar. Destituídos da força de trabalho, passam a viver em situações precárias em bairros afastados e carentes, sobrevivendo com a ajuda de vizinhos, amigos e familiares.

As mudanças no setor sucroalcooleiro no contexto regional contribuíram em peso para o aumento de problemas sociais relacionados à mendicância, miséria, alcoolismo e violência nos centros urbanos, pois foram as cidades que acabaram absorvendo essa população e, consequentemente, geraram mazelas resultantes de uma cruel exploração. E isso acaba ocorrendo não apenas nas cidades da região, pois o processo e a territorialidade que abrange também permite o des- 
locamento do trabalhador para outras cidades da rede urbana. Se com a diluição das fronteiras entre cidade e campo, por um lado, a produtividade exigida pelas empresas passou a explorar mais os trabalhadores agrícolas menos qualificados, por outro, as lutas do campo ganharam visibilidade, e os trabalhadores, representatividade e estruturas que reconfiguraram as lutas do campo, transpondo-as para o contexto urbano - como o Movimento dos Sem-Terra e suas manifestações, realizadas em prédios de prefeituras, de superintendências do Instituto Nacional de Colonização e Reforma Agrária (INCRA), visando melhorias nas condições dos trabalhadores rurais e exigindo a desapropriação de terras inertes de latifúndios e sua redistribuição a famílias de agricultores.

No contexto paulista, têm-se as instituições de ensino superior, que contribuem com o debate, e a configuração de instituições específicas, como o STR (Sindicato de Trabalhadores Rurais) e a FERAESP (Federação dos Sindicatos de Trabalhadores Rurais Assalariados do Estado de São Paulo), o Ministério Público do estado, organismos institucionais (Ministério do Trabalho), além das ONGs (Pastoral dos Migrantes, Plataforma DHSC) e representantes de Universidades. Assim, teria ocorrido

\begin{abstract}
(...) um alargamento do campo das contradições entre capital e trabalho. Neste embate, esses atores não só se fazem presentes, como também possuem poderes, embora diferenciados, capazes de redirecionar os antagonismos, por meio de pressões em torno da obediência às normas legais, impondo, portanto, limites à voracidade destes capitais e exigindo do Estado a regulação das relações de trabalho, indo de encontro à desregulação e flexibilização impostas pelo capitalismo mundializado ${ }^{100}$.
\end{abstract}

No período entre 2005 e 2007, várias audiências públicas foram realizadas em Ribeirão Preto para retratarem a realidade de exploração e as condições precárias do trabalhador agrícola nos canaviais. Segundo SILVA (2010), a promotoria do Ministério Público teria apontado que houve, por parte do Ministério do Trabalho, do INSS e da Vigilância Sanitária, omissões, descasos e conivência com a situação. No mesmo período, a PRT15 (Procuradoria do Trabalho da 15a Região do Estado de São Paulo) desenvolveria ações em conjunto com o Fórum de Cidadania, envolvendo pesquisadores, políticos locais, representantes dos trabalhadores e de instituições públicas relaciona-
100. SILVA, M. A., M., MARTINS, Rodrigo C. A degradação social do trabalho e da natureza no contexto da monocultura canavieira paulista. In: Revista Sociologias, Porto Alegre, ano 12, n. 24, mai/ago. 2010, p. 226 . 
101. A Norma Regulamentadora 31 estabelece os preceitos a serem observados na organização e no ambiente de trabalho, de forma a tornar compatível o planejamento e o desenvolvimento das atividades da agricultura, pecuária, silvicultura, exploração florestal e aquicultura com a segurança e saúde e meio ambiente do trabalho.

102. “Um dos problemas ressaltados nas ações diz respeito ao caráter indevido da criação de um selo trabalhista pela União, que bate de frente com a já ratificada Convenção 81 da Organização Internacional do Trabalho (OIT) - referente à manutenção e estruturação da atividade de inspeção do trabalho (que, no caso do Brasil, é atribuição do MTE), não sendo autorizada a criação de outros mecanismos, sem qualquer autorização legislativa, que comprometam a atividade prevista. Para esse tipo de certificação de caráter trabalhista, as usinas poderiam perfeitamente recorrer a iniciativas privadas já existentes como a SA (Social Accountabilty) 8000 ou o selo da Bonsucro (parte do esforço transnacional Better Sugar Initiative), que não suscitam qualquer tipo de incompatibilidade com a fiscalização estatal brasileira." (HASHIZUME, Maurício. MPT pede cassação do selo de 'empresa compromissada' concedido a usinas sucroalcooleiras. Repórter Brasil, out./2012. Disponível em: <http://reporterbrasil.org.br/2012/10/mpt-pedecassacao-de-quot-selo-social-quot-concedido-a-usinaspelo-planalto/>. Acesso em 03/06/2014.

103. ALVES, Francisco. Por que morrem os cortadores de cana. In: Saúde e Sociedade, v. 15, n. 3, p. 97, set/2006.

104. A produção sucroalcooleira apresenta altos índices de poluição. Fuligem, gases emitidos com a queima da cana-de-açúcar são prejudiciais ao meio ambiente e comprometem a saúde da população das áreas urbanas da região. Apesar dos problemas, as queimadas são amparadas pela Lei Estadual N. 11.241/2002, que permite a queima até 2031. Contudo, um protocolo fora firmado entre governo do estado e as usinas reduzindo este prazo para 2014 para áreas mecanizáveis e 2017, para as não mecanizáveis. das, com o intuito de aumentar a fiscalização nos canaviais, para garantir menor exploração da mão-de-obra no local de trabalho e condições mínimas de salubridade nos alojamentos e no fornecimento de água e alimentos. Entretanto, uma série de travas impostas por usineiros e representação sindical dificultaram o cumprimento da NR31 ${ }^{101}$; por exemplo, segundo SILVA (2010), a existência de lobbies de empresários que influenciavam vetos de projeto de lei relativos ao cumprimento de normas trabalhistas.

Em 2012, o Ministério do Trabalho solicitou cassação do selo "empresa compromissada" concedido a usinas, devido a uma série de irregularidades tanto no próprio processo de atribuição do "selo social", quanto na documentação solicitada às usinas (conversão de dados falsos em dados reais e omissão de dados sobre irregularidades, que poderiam ter consequências negativas para as exportações) $)^{102}$. A inexistência de processo administrativo para a concessão dos selos e a desconsideração dos passivos e das denúncias de organizações da sociedade civil também foram aspectos que causaram polêmica ao redor dos selos de "empresa compromissada".

A concepção de normas regulamentárias para o trabalho agrícola quanto à atuação do Ministério Público e do Ministério do Trabalho, denunciando as situações subumanas às quais os trabalhadores são submetidos, revelam que houve uma reestruturação não só da organização e reconhecimento do trabalho, como também na esfera da legislação e do papel do Estado enquanto mediador das lutas trabalhistas dos cortadores de cana. Segundo ALVES (2006), talvez a mecanização completa dos processos relativos à cana-de-açúcar seja uma das melhores alternativas para acabar com a realidade da exploração.

Contudo o autor afirma que seria necessário um grande avanço tecnológico para que as máquinas atingissem as áreas plantadas nos relevos mais variados possíveis, ou uma realocação espacial da monocultura, mas que esta última alternativa, além de pressupor uma alteração do gênero agrícola a ser cultivado, também esbarraria nos limites da propriedade e uso privativo da terra no Brasil ${ }^{103}$. Especificamente no estado de São Paulo, o corte manual da cana-deaçúcar tem entrado em colapso em virtude da proibição da queima dos canaviais no estado a partir de $2014^{104}$, conforme descreve a reportagem na figura 16. Deste modo, a cana-de-açúcar só poderá ser cortada crua, o que dobrará a remuneração do cortador para quase $\mathrm{R} \$ 8$ por tonelada (conforme definido em acordo coletivo), onerando as usinas. 


\section{RISCO DE EXTINÇÃO}

\section{Cortadores temem 'ameaça' da mecanização do trabalho}

Alvo de multas pesadas pelos baixos salários, setor intensifica uso de colheitadeiras. Trabalhadores sem instrução têm medo de ser substituídos

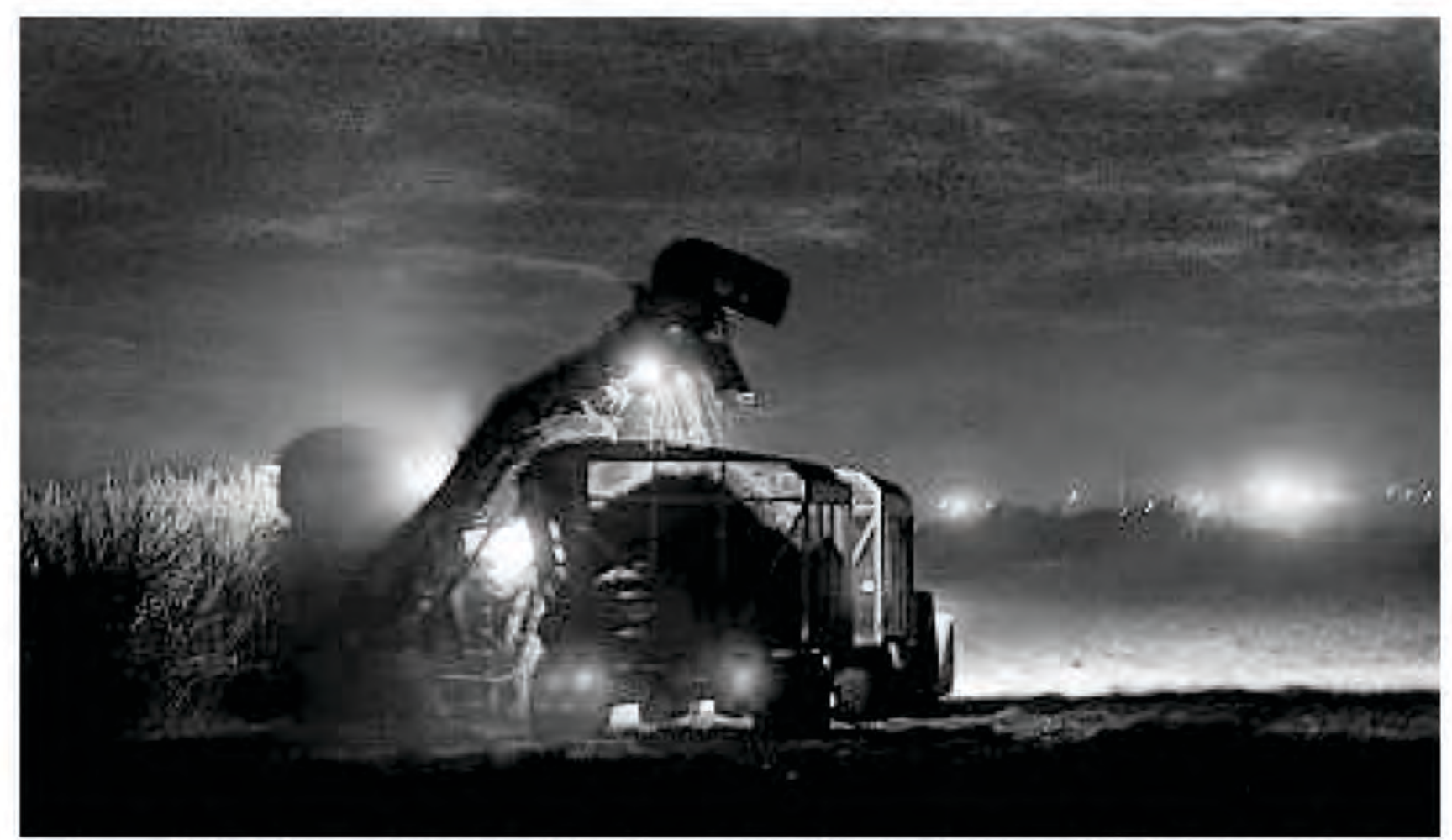

Mudança. Colheitadeiras substituem trabalhadores: no passado, exaustão causava 3 a 4 mortes a cada ano

Figura 16 - Cortadores temem "ameaça" da mecanização do trabalho.

Fonte: O Globo, Rio de Janeiro, p. 41, domingo, 28 de abril de 2013. 
flamenguista José Araújo dos Santos, de 52 anos, corta oito toneladas de cana das $7 \mathrm{~h}$ às $15 \mathrm{~h}$ todos os dias com seu afiado facão nos canaviais da Usina da Pedra, em Serrana, região de Ribeirão Preto, a principal produtora de açúcar e álcool do país. Como recebe $\mathrm{R} \$ 4,15$ por tonelada cortada, chega a ganhar pouco mais de $\mathrm{R} \$ 1$ mil por mês. Mas ele não reclama de ganhar pouco e trabalhar exaustivamente sob um sol escaldante. Pelo contrário, ele está preocupado é com o fim dos cortadores de cana. Hoje as máquinas já colhem $90 \%$ da cana plantada na região e no ano que vem esse índice deve ser de $100 \%$.

- As usinas vão dispensar os cortadores. Só vai ter emprego quem souber pilotar as máquinas. Como sou analfabeto, não tenho como aprender. Sem emprego, vou morrer de fome se continuar aqui. Vou ter que voltar para a Bahia, de onde vim para cortar cana. Meus amigos estão indo trabalhar na construção civil, em Ribeirão Preto - disse José dos Santos, que corta cana com a mulher Terezinha, de 42 anos, que também deve ficar sem emprego no ano que vem.

Uma máquina faz o trabalho de cem homens e os cortadores de cana, que já foram 60 mil nos 40 municípios da região, hoje são apenas dez mil e no ano que vem podem deixar de existir. É que o corte manual só é feito depois que os canaviais são queimados e em terras com declive, onde as máquinas não chegam. No ano que vem, a queima nos canaviais está proibida em São Paulo e as usinas só vão plantar onde as máquinas podem operar.

- A partir do ano que vem, a usina não pode mais queimar a cana, que só vai poder ser cortada crua. E para se cortar a cana crua, o preço dobra para R $\$ 8$ por tonelada, conforme prevê acordo coletivo, o que encarece o custo das usi-

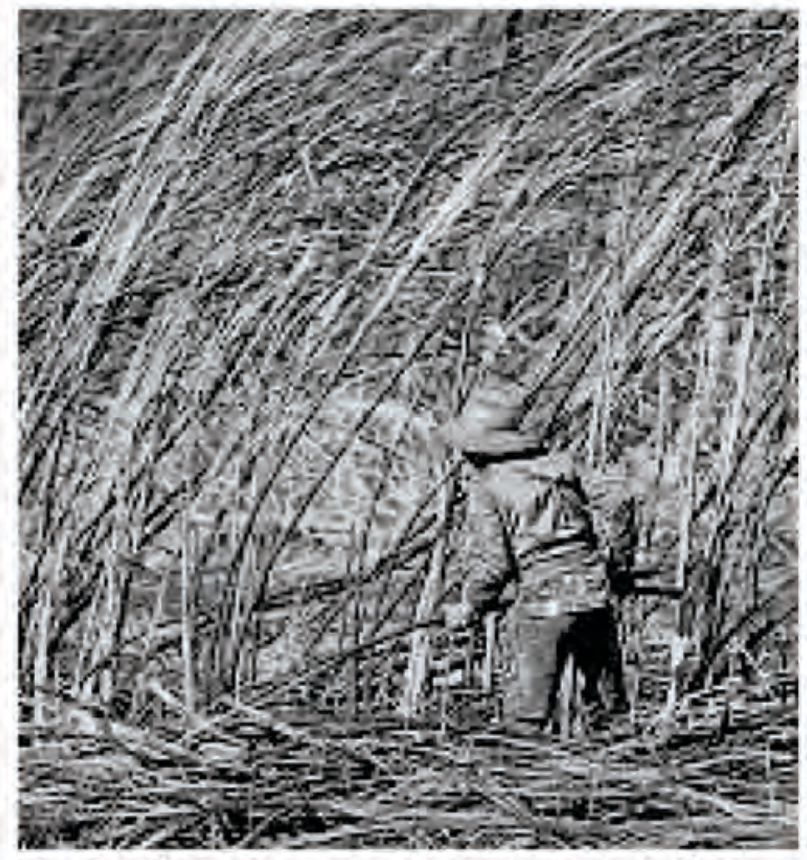

Direito. Cortadores agora têm jornada de até 8 horas

nas. Por isso, a cana só será plantada onde as máquinas podem cortar. Será o fim do cortador manual - disse Silvio Donizetti Palviqueres, presidente do Sindicato dos Trabalhadores $\mathrm{Ru}$ rais de Ribeirão Preto.

O processo de mecanização da colheita de cana, que já vinha sendo usado gradativamente nos canaviais, se intensificou em 2008 e 2009, depois que o setor sofreu pesadas multas por pagar pouco aos cortadores, em trabalho considerado degradante e em condições desumanas. Todo ano morriam de 3 a 4 cortadores de cana, por trabalharem até a exaustão. Os usineiros, então, dinamizaram o uso das colheitadeiras de cana. E os cortadores passaram a ter maiores garantias no trabalho, com jornada limitada a oito horas, com descanso de uma hora para o almoço e intervalos de 15 minutos para descanso. Isso acabou com as mortes em canaviais, mas aumentou o custo da mão de obra. (G.O.) 
Deste modo, a cana-de-açúcar tenderá a ser plantada apenas onde as máquinas poderão executar a colheita.

Tal medida não encerra o processo de exploração dos trabaIhadores volantes e sazonais, pois em outros estados brasileiros, onde há intensa produção sucroalcooleira, não existe tal proibição. E é para lá que tais migrantes provavelmente irão. Deste modo, a reestruturação do território produtivo sucroalcooleiro gerará novos polos de deslocamento para esses migrantes, intensificando a exploração do trabalho em outros estados, ou até mesmo reproduzindo-a em novas áreas. Ou ainda, tal população será absorvida em atividades urbanas nãoespecializadas e de baixa remuneração, comumente relacionadas ao setor da construção civil. Há de se concordar com HARVEY ao afirmar que tais trabalhadores

\begin{abstract}
trabalham sob diferentes condições (muitas vezes com baixos salários, em trabalhos temporários e precários, no caso da construção e urbanização [e nos canaviais brasileiros]). Sua mobilidade, dispersão espacial e condições de trabalho individualizadas podem tornar mais difícil a construção de solidariedades de classe ou a criação de formas coletivas de organização [tornando-se mão-de-obra dócil e de fácil manipulação, ficando sob controle dos proprietários e até mesmo de forças sindicais]. Sua presença politica é mais frequentemente marcada por tumultos espontâneos e levantes voluntaristas (...), mais do que organização permanente. Mas eles têm plena consciência de suas condições de exploração e estão profundamente alienados por sua existência precária e muitas vezes revoltados com o policiamento brutal de suas vidas diárias pelo poder estatal ${ }^{105}$.
\end{abstract}

É preciso observar que, no caso de Guariba, cuja população na época da greve de 1984 era 60\% composta por cortadores de cana, atualmente possui população de 35 mil habitantes, dos quais pouco menos que 1,1 mil são cortadores. Às vésperas do fim do corte manual, grande parte migrou para outras áreas de colheita em outros estados (como Minas Gerais ou Paraná), ou foram absorvidos em outras atividades de baixa qualificação em outras cidades da região. Segundo SILVA (2001),
Apesar da diminuição desta demanda, assiste-se a cada ano, às cenas de centenas de trabalhadores, que, mesmo sem terem a certeza de encontrarem trabalho, chegam às cidades desta região [de Ribeirão Preto]. Muitos são obrigados a regressar aos locais de origem, embarcando nos próprios ônibus que os trou- 
106. SILVA, M. A. M. Reestruturação produtiva e os impactos sobre os migrantes. In: Una nueva ruralidad en América Latina?, Buenos Aires, 2001, p. 289-305.

107. MAIA, E. Nomes de seis construtoras que atuam em Juiz de Fora estão na lista suja do trabalho escravo. Acessa.com, 03 de jul. 2014. Cidades, notícias. Disponível em:

<http://www.acessa.com/cidade/arquivo/noticias/2014/0 7/03-seis-construtoras-que-atuam-em-jf-estao-na-listado-trabalho-escravo/>. Data de acesso: 07 de ago. 2014.

108. BRASIL. Ministério Público do Trabalho. Termo de ajuste de conduta $n^{0}$ 2339/2011. Portal Transparência. Disponível em:

<http://mpt.gov.br/portaltransparencia/downloadtac.php ?IDDOCUMENTO=791527>. Data de acesso: 06 de ago. 2014.

109. EPTV. Construtora MRV é condenada a R\$ 4 milhões por trabalho escravo em obra. 07 de ago. 2011. Disponível em: <http://g1.globo.com/sp/campinasregiao/noticia/2013/08/construtora-mrv-e-condenada-r4-milhoes-por-trabalho-escravo-em-obra.html>. Data de acesso: 22 de jan. 2015 xeram. Outros se empregam. Outros perambulam de um lugar a outro em busca de trabalho para a sobrevivência $^{106}$.

Deste modo, não se resolve o problema da exploração (até porque ela se faz necessária para realização da produção agroindustrial e da dinâmica do agronegócio), mas apenas o realoca, tanto do ponto de vista geográfico quanto do ponto de vista de esferas produtivas. Geograficamente, distancia-o das principais regiões produtoras (no caso, o estado de São Paulo), criando a falsa realidade de que o cultivo da cana estará associado plenamente à tecnologia, energia limpa, sustentabilidade e trabalho mecanizado, importante vitrine do "progresso tecnológico" para o agronegócio brasileiro. Assim, a reprodução da estrutura da agropecuária brasileira não deixará de manter seu caráter social e espacialmente excludente, promovendo o acirramento de desigualdades socioespaciais no ambiente urbano e agrícola tanto a nível regional quanto a nível intraurbano.

A exploração provinda do campo também é realocada do ponto de vista de esferas produtivas: ocorre uma transferência de mãode-obra de um setor ao outro. Sem melhores qualificações, os cortadores de cana são reinseridos à realidade urbana, em empregos do mesmo nível que suas competências, como mão-de-obra barata no setor da construção civil. Porém a exploração se mantém, conservando as mesmas raízes arcaicas. Em 2011, a PDG Realty S/A, grande grupo empresarial no ramo imobiliário, e uma sociedade na qual investe, aAPI SPE 24 - Planejamento e Desenvolvimento de Empreendimentos Imobiliários -, atuante no estado de Minas Gerais, sofreram processo referente a acusações de trabalho escravo no setor da construção civil, em razão das obras do conjunto residencial Ville Rubi, em Juiz de Fora - $M G^{107}$. Entendendo a produção do espaço urbano enquanto um processo produtivo de commodity, tal qual visto no campo, é possível estabelecer um paralelo com a exploração de trabalho em ambas as esferas. Conforme análise do TERMO DE AJUSTE DE CONDUTA N ${ }^{\circ}$ 2339/2011, as acusações e exigências listadas pelo Ministério Público, no que diz respeito aos trabalhadores da construção civil, revelam uma situação de extrema precariedade ${ }^{108}$, análoga à encontrada nos canaviais. Em Americana, a construtora MRV Engenharia foi condenada por prática de trabalho escravo e condições precárias, em $2013^{109}$. Em Hortolândia, trabalhadores foram encontrados em condições degradantes em obras do programa do governo federal Minha Casa, Minha 
Vida ${ }^{110}$, gerenciada pelas empresas Faleiros e Múltipla, envolvendo contratações de outras 30 empreiteiras. De acordo com o Ministério do Trabalho e Emprego - MTE, das cerca de 600 empresas brasileiras que submetem trabalhadores a condições análogas às de escravidão, 110 estão relacionadas ao setor agrícola ( 88 em cultivos diversos, 10 no cultivo cana-de-açúcar, e 102 no setor de agropecuária) e 35 foram listadas no setor de construção civil ${ }^{111}$.

A exploração do trabalho contribui e reforça o fenômeno da favelização, decorrente dos processos de urbanização e industrialização, que tem se ampliado para além das grandes aglomerações urbanas e surgido em diversas regiões do país, dentre elas na região metropolizada de Ribeirão Preto, conforme visto anteriormente na figura 13 (p. 63). Em uma análise interna ao município, foram encontrados assentamentos precários nas periferias da cidade, com maior predominância no setor norte.

O impacto da modernização, do capital financeiro e das novas formas de exploração do trabalho não homogeneizou o território, mas gerou desigualdades novas, privilegiando áreas e segmentos econômicos e sociais específicos, hierarquizando informações e sistemas urbanos, fixos e fluxos - estruturadores do espaço urbano onde se processam jogos de relações dialéticas entre o arcaico e o moderno, mercados e Estado. Quanto mais dinâmica a reestruturação produtiva e mais globalizados os círculos espaciais da produção e de cooperação, mais complexas se tornaram as relações cidade-campo, aprofundando-se a divisão social e territorial do trabalho, remodelando o território e reorganizando o sistema urbano, que acabou configurando uma rede de aglomerações urbanas para realização da produção destinada ao agronegócio globalizado.

No campo, FERREIRA e ALVES (2009) apontam uma (re)inauguração de novas modalidades de fusão entre usinas no território paulista: se com o Programa de Racionalização da Agroindústria Açucareira, em 1971, usinas antieconômicas eram incorporadas às grandes usinas, por volta dos anos 2000, grandes grupos economicamente viáveis passaram a incorporar usinas economicamente viáveis. A recente queda do preço do açúcar já nos anos 2000, junto com a desaceleração da expansão do mercado de etanol e a redução de incentivos do consumo desencadeou uma profunda crise no setor sucroalcooleiro. De acordo com HARVEY:
110. ROCHA, M. Trabalho degradante é encontrado em Minha Casa, Minha Vida. Repórter Brasil, 20 de abr. 2011. Disponível em:

<http://reporterbrasil.org.br/2011/04/trabalhodegradante-e-encontrado-no-minha-casa/>. Data de acesso: 22 de jan. 2015.

111. BRASIL. Ministério do Trabalho e Emprego. Cadastro de empregadores. Portaria interministerial $\mathrm{n}^{\circ} 02$ de 12 de maio de 2011. Atualização semestral em $1^{\circ}$ de julho de 2014. Disponivel em: <http://portal.mte.gov.br/portalmte/>. Acessado em 06 de ago. 2014.

OS CONFLITOS NA DISTRIBUIÇÃO DE TERRAS, FUSÕES E TRANSNACIONALIZAÇÕES 
Os países que dependiam fortemente dos EUA como principal mercado de exportação [tal como o Brasil o tinha como principal polo de exportação de açúcar] acabaram sendo puxados para baixo, assim como os mercados acionários, enquanto produtores de matérias-primas e bens, que estavam em alta no início de 2008 e consideravam-se imunes à crise, de repente se viram em sérias dificuldades quando os preços das matérias-primas e bens despencaram no segundo semestre de $2008^{112}$.

Sem amparo do Estado para regulamentar o mercado, as fusões, associações e aquisições revelaram-se alternativas de salvação dos agentes produtivos, reestruturando todo o arranjo empresarial para contornar os efeitos da crise.

No que tange à fusão entre usinas, o caso da família Junqueira Franco ilustra o processo na região de Ribeirão Preto. Em 2007, a usina Vale do Rosário, propriedade da família, recebeu uma proposta de compra pelo Grupo Cosan. A venda foi recusada, porém meses mais tarde surgiu uma proposta de fusão entre a usina da família Junqueira Franco e a Santa Elisa, da família Biagi, com o intuito de fortalecer os negócios das duas famílias (ambas gigantes expoentes da cana-de-açúcar na região de Ribeirão Preto). Foi criada a Santelisa Vale.

Outro caso de fusão entre empresas concorrentes foi protagonizado pela Dedini e a Zanini, dois grupos do setor sucroalcooleiro regional. A Dedini S.A. Indústrias de Base, empresa fundada em $1920 \mathrm{com}$ capital $100 \%$ nacional e estrutura familiar, sob controle do grupo Ometto, atua em vários segmentos industriais de infraestrutura e insumos básicos, energia e alimentos, destacando-se enquanto líder mundial no fornecimento de equipamentos e plantas completas para o setor sucroalcooleiro. Possui sede na cidade de Piracicaba - SP, e outras seis unidades industriais, localizadas em Maceió, Recife e Sertãozinho, totalizando um conjunto de nove fábricas, em área de mais de um milhão de metros quadrados. Em 1980, foi formada a Dedini S/A Administração e Participações, a fim de controlar e gerenciar os interesses das empresas. Como holding do grupo, passou a exercer as funções de empresa acionista e controladora, tendo as famílias Dedini e Ometto como acionistas majoritárias.

Para disputar o mercado internacional, em 1992, efetuou-se uma fusão entre Dedini e Zanini, esta pertencente à família Biagi, de Sertãozinho, gerando a DZ Engenharia Equipamentos e Sistemas, sendo considerada a maior fabricante de máquinas e equipamentos para usinas de açúcar e álcool do país. Após uma crise em 1995, todo o 
controle acionário passou a pertencer totalmente ao Grupo Dedini. Atualmente, o grupo possui um território de atuação comercial bastante amplo, desde o nível nacional até o internacional, contemplando todo o continente americano, Caribe, Oceania e o sudeste asiático.

Entre 1996 e 1999, foram constatadas apenas sete fusões e aquisições de agroindústrias, menos de duas fusões por ano. Já entre 2000 e 2007, este número saltou para 80 , com uma média anual de 10 fusões e aquisições. Tais fusões e aquisições tiveram apoio do Banco Nacional de Desenvolvimento Econômico - BNDES -, através de recursos destinados ao setor ( $R$ \$ 605 milhões, em 2004, e $R \$ 3,6$ bilhões, em 2007). O Grupo Cosan S/A foi o único brasileiro que registrou maior número de fusões nos anos 2000, ampliando de seis para dezoito unidades produtivas em sete anos.

A Cosan atua no setor sucroalcooleiro desde 1936, com a fundação da usina Costa Pinto no município de Piracicaba, e passou a ampliar sua atuação no setor, obtendo o controle de atividades relacionadas à produção sucroalcooleira, como a distribuição e comercialização de combustíveis e lubrificantes. Atualmente comandado por Rubens Ometto Silveira Mello, o grupo corresponde a uma das maiores corporações empresariais do Brasil, atuando nos setores de produção de energia e infraestrutura, logística, sucroalcooleiro, combustíveis e lubrificantes. Em 2005, o grupo abriu seu capital na BM\&FBOVESPA com US\$ 400 milhões. Em 2010, consolidou sua atuação no mercado de combustíveis em uma associação com a Shell nos negócios de açúcar, etanol e distribuição de combustíveis, evoluindo para uma joint venture, originando a Raizen no ano seguinte, internacionalizando seu capital. O grupo se tornou o maior distribuidor de gás do país, com a aquisição da Comgás, em 2013. Em 2008, a Cosan adquiriu a Esso no Brasil, efetivando a participação no setor de distribuição de combustíveis.

As grandes propriedades, em sua maioria, estavam associadas a famílias que controlavam grande parte da produção sucroalcooleira. Mesmo com o grande número de fusões, muitas empresas nacionais se viram sem saída para contornar a crise e permanecer no setor. Em fins dos 2000, havia-se criado expectativas de que o mercado internacional absorveria de fato o etanol e sua imagem construída de combustível alternativo, viável e "sustentável". Muitos empresários do setor acreditavam que a solução para a crise do setor sucroalcooleiro gerada pelo açúcar seria trazida pelo etanol. Com influência dos Estados Unidos, buscou-se uma tentativa de expansão para o consumo do com- 
113. Dados do Instituto de Economia Agrícola do estado de São Paulo (BRASILDE FATO. As novas e velhas contradições do etanol. 13 de junho de 2011. Disponível em: < http://www.brasildefato.com.br/node/6577 > Acesso em: 09 de maio de 2014).

114. BRASILDE FATO. As novas e velhas contradições do etanol. 13 de junho de 2011. Disponível em: < http://www.brasildefato.com.br/node/6577 > Acesso em: 09 de maio de 2014

115. BIOSEV, 2012. bustível. Entretanto o mercado internacional pouco se abriu à alternativa bioenergética. Mesmo com a dificuldade de aceitação internacional, a expansão interna fora bastante intensa, reestruturando o setor sucroalcooleiro nacional. Aumentou-se o volume produzido, bem como a área plantada (em Ribeirão Preto, os canaviais ocupavam 183.391 ha, em 1983, chegando a 362.583 ha, em 2010) ${ }^{113}$.

Os processos de transnacionalização e de multinacionalização se acentuaram e se tornaram bastante recorrentes durante a década de 1990, estabelecendo-se enquanto alternativa tanto para grandes grupos expandirem seus territórios de atuação para outras localidades e conquistarem novos mercados, quanto para muitos empresários que quiseram evitar a falência. Assim, muitas empresas estrangeiras se instalaram no território através de fusões, associações e sociedades com os grupos brasileiros e passaram a controlar a produção em terras nacionais. Empresas estrangeiras de capital aberto, como Cargill, Tereos, Adeco, Nouble, Infinity Bio-Energy e Abengoa ampliaram sua participação no setor e no território brasileiro através de fusões e aquisições de usinas e indústrias, até então sob o controle de grandes famílias nacionais. De acordo com dados da União dos Produtores de Bioenergia - UDOP -, em 2007, a participação de transnacionais na moagem de cana-de-açúcar era de $9,21 \%$, subindo para $11,1 \%$, em $2008^{114}$.

Dentre elas está a francesa Louis Dreyfus - LD Commodities -, fundada em 1851, voltada para a produção de grãos e que, no final do século XIX, já possuía escritórios na França, Alemanha e Rússia e iniciava as operações de trading em mercados futuros. Após adquirir a empresa Comércio e Indústrias Brasileiras - Coinbra S.A. -, em 1942, expandiu suas atividades também para o setor de açúcar, produtos cítricos e café, consolidando-se no país. Atualmente, possui sede na capital de São Paulo, além de unidades fabris no sul, sudeste, nordeste e centro-oeste brasileiros, compreendendo quatro fábricas processadoras de oleaginosas e três de suco de laranja (adquiridas durante a década de 1990), oito unidades de fertilizantes, cinco terminais portuários e dois hidroviários, além de treze usinas de açúcar e etanol (frutos de aquisições e fusões com usinas e destilarias de famílias nacionais). Também administra, em território nacional, cerca de 340 mil hectares de terra agrícola. A LD Commodities está presente em 55 países, sendo o grupo com maior participação em nível mundial na comercialização de algodão e no mercado de $\operatorname{arroz}^{115}$. Em 2009, a LD Commodities com- 
prou o capital da Santelisa Vale, usina fruto da fusão entre Biagi e Junqueira Franco, uma das muitas empresas familiares que controlavam a produção sucroalcooleira no país e que se viram endividadas. Muitas acabaram se tornando sócias minoritárias do próprio negócio, tendo a maior parcela de suas ações apoderadas por grandes empresas (muitas delas estrangeiras), reflexo de um processo de concentração cada vez mais intenso no setor. Atualmente, os Biagi e os Junqueira Franco arrendam terras e fornecem cana para a holding francesa e possuem apenas 5,9\% das ações do grupo, rebatizado como BioSev.

O grupo Dedini, dos Ometto, também teve um episódio relacionado a transações com empresas estrangeiras. Além das indústrias de base, o grupo também atuava no setor de produção sucroalcooleira, através da Dedini Agro, que possuía duas usinas de açúcar e álcool - a unidade São Luiz e a São João, ambas em cidades do estado de São Paulo (Pirassununga e São João da Boa Vista, respectivamente). Ambas processavam juntas 6,2 milhões de toneladas. Em 2007, a Dedini Agro foi comprada pela espanhola Abengoa, maior empresa produtora de álcool na Europa e a quinta nos EUA. A compra custou US\$297 milhões mais a dívida das usinas, totalizando US\$ 684 milhões. Com isso, a Abengoa efetivou sua participação nos principais mercados de álcool do mundo -EUA, Brasil e Europa.

Em 2012, uma fusão bastante importante no setor sucroalcooleiro foi a da brasileira Copersucar S/A. O grupo foi criado em 2008 por 47 unidades produtoras sócias, as mesmas que originaram, em 1959, a Cooperativa de Produtores de Cana-de-Açúcar, Açúcar e Álcool do Estado de São Paulo, tornando-se nó importante que aproxima 24 grupos econômicos que controlam a produção de tais unidades. Em parceria com outros grupos empresariais relacionados ao setor, em 2011, firmou associações através da Logum Logística S. A., para investimentos no projeto e construção de polidutos interligando as regiões produtoras aos grandes centros consumidores. Em 2012, adquiriu a norteamericana Eco-Energy, uma das principais tradings de biocombustíveis dos Estados Unidos, concentrando $12 \%$ da produção de álcool mundial, visando à internacionalização e atuação da empresa nos EUA - um dos maiores mercados de etanol do mundo junto com o Brasil, tanto em volume de produção quanto no de consumo -, tendo como foco atingir o mercado europeu, expandindo o fornecimento de açúcar e etanol. Segundo o diretor-presidente da Copersucar, a operação foi financiada por captação no exterior, definindo-se enquanto uma linha de longo pra- 


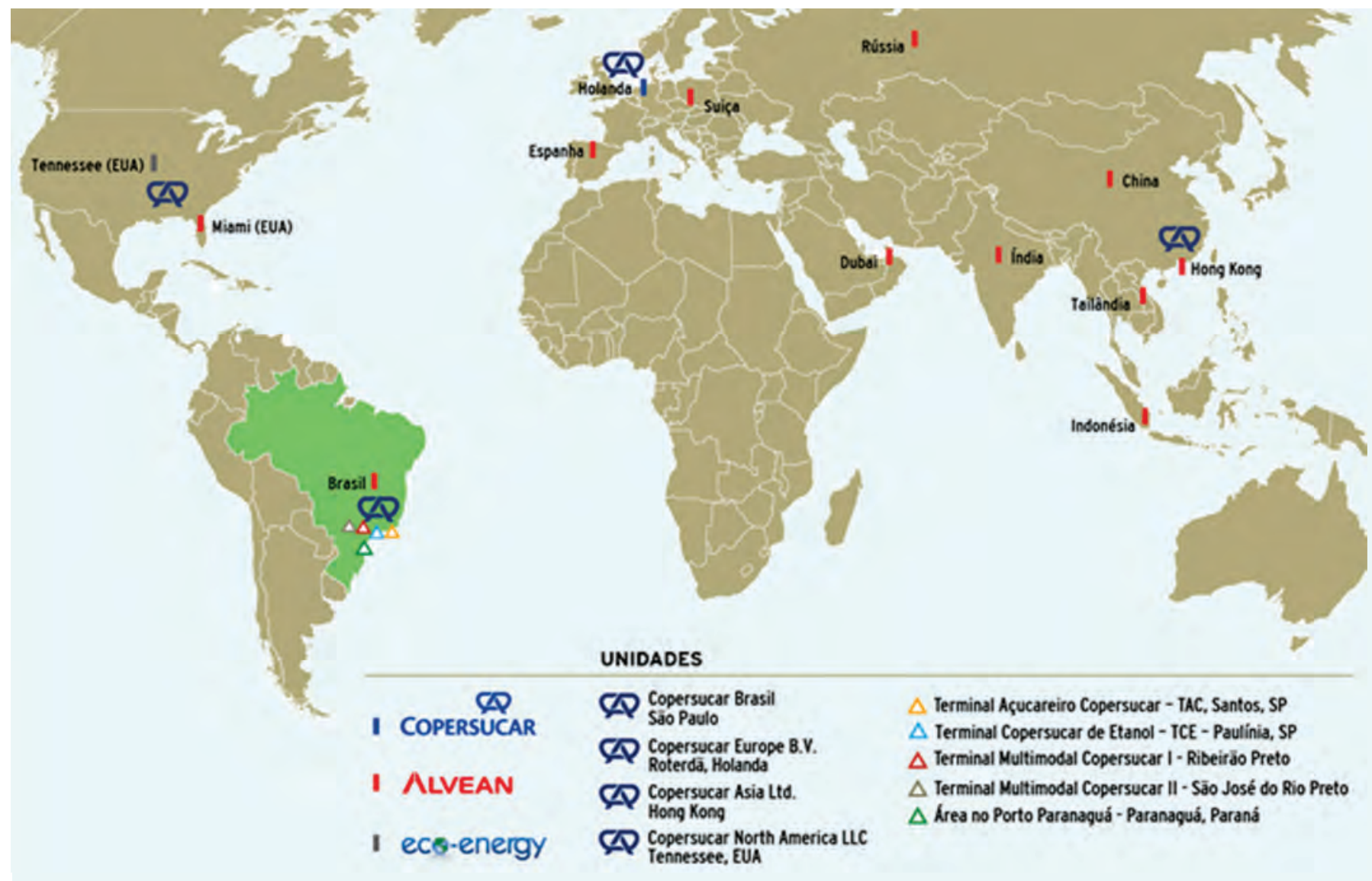

Figura 17 - Área de atuação global da Copersucar. Fonte: Copersucar, 2014. 
zo, caracterizada como project finance, linha de crédito compatível com a capacidade do negócio de gerar recursos para pagamento da dívida que se produziu juntamente com sua criação.

Após a aquisição da Eco-Energy, passou a atuar como uma das principais empresas no mercado sucroalcooleiro norte-americano, ampliando posteriormente sua atuação no mercado europeu, com uma unidade em Roterdã, Holanda. No segmento açucareiro, criou a subsidiária Copersucar Asia, com sede em Hong Kong, de modo a conquistar também o mercado chinês. Para garantir a eficiência logística, em conjunto com o grupo Jamal Al-Ghurair, controlador da maior refinaria de açúcar do mundo (Al Khaleej Sugar - AKS), criou a Copa Shipping Company Limited, com o intuito de contratar e gerenciar o transporte marítimo de açúcar e etanol.

Conforme a figura 17, a empresa possui sede e estruturas produtivas no Brasil e escritórios nos EUA, Holanda e Hong Kong, exportando açúcar para 37 países, e concentrando o destino de etanol em 16 países (dentre eles EUA, Jamaica, Trinidad e Tobago, Nigéria, Coreia do Sul, Japão e outros 10 europeus). Não há dúvidas de que o território do complexo sucroalcooleiro compreende, para além dos canaviais e agroindústrias brasileiros, uma série de outras empresas transnacionais e de logística, além dos principais mercados consumidores e também centros do capitalismo mundial (EUA, Europa e China), consolidando a participação do Brasil em uma economia sucroalcooleira global.

Todo esse processo de fusões, aglutinações e aquisições empresariais, encontrado como alternativa a uma crise mercadológica, aumentou a concentração fundiária sob controle de grandes grupos empresariais do setor privado. $E$ isso trouxe consequências sérias no que corresponde à propriedade da terra e na produção de alimentos para consumo interno - com foco no pequeno produtor e na agricultura familiar. Mesmo com o governo do estado regulando a ampliação do parque canavieiro nos anos 1980, com o Pró-Oeste, de modo a não ocupar terras com produção de alimentos para abastecimento interno, o aumento das áreas de monocultura canavieira especializada no estado, voltadas para demandas agroindustriais e exigências mercadológicas em nível global, foi inevitável, principalmente a partir dos anos 1980.

A reestruturação do território voltado para produção de expor-
OS CONFLITOS

NA PRODUÇÃO ALIMENTAR 
116. A agricultura familiar, por definição é tida como a produção agrícola efetuada por pequenos proprietários de terra tendo como mão-de-obra essencial o núcleo familiar. Atualmente, a maior parcela dos alimentos consumidos no país são de origem de pequenos proprietários. Dados do Censo Agropecuário de 2006 apontam que a produção agrícola familiar no valor bruto da produção gerado é de $\mathrm{R} \$ 54$ bilhões, aproximadamente $38 \%$. Em 2006, havia 4,37 milhões de estabelecimentos familiares no país $(84,4 \%)$, contudo a área desses estabelecimentos correspondia apenas $24,3 \%$ da área total da produção, de modo que os outros $75,6 \%$ estavam sob controle de apenas 807.587 estabelecimentos não-familiares (grandes grupos empresariais e corporações alimentícias).

117. Em contrapartida, o desenvolvimento agroindustrial produziu novos hábitos de consumo alimentar, tais quais os enlatados e instantâneos.

118. SANTOS, 1979. tação pressupôs também uma reorganização nos polos de produção de alimentos, interferindo na agricultura familiar ${ }^{116}$. No estado de São Paulo, devido à redução de terras para o cultivo de alimentos, a produção decaiu, gerando uma demanda por gêneros alimentícios básicos provenientes de outros estados do país, e até mesmo na importação ${ }^{117}$.

A aproximação da produção agrícola da produção industrial, seja das indústrias que lhe beneficiam, seja das que se beneficiam do cultivo, gerando produtos derivados, revelou que a inovação tecnológica assistida ocorrera com maior afinco e disposição para circuitos de produção voltados para a exportação, tendo a produção agrícola e seu funcionamento cada vez mais regulados por economias de mercado, objetivando troca e comércio, conforme demandas urbanas e industriais, restringindo a produção de subsistência para consumo interno. Os circuitos espaciais de produção agrícola e os circuitos de cooperação necessários à sua realização extrapolaram os limites da propriedade rural de uma região ou país, transformando a agricultura numa "atividade associada ao circuito superior da economia"118.

Segundo ASSUNÇÃO (2014), o agronegócio não é capaz de alimentar a população brasileira, pois busca tornar as áreas agricultáveis em locus de produção voltados para a exportação, o que acaba encarecendo alimentos básicos para abastecimento, pois, uma vez importados, passam a ser regulados por mercados financeiros. $E$ de comum acordo com SHIVA (2013), a produção de commodities é distinta da produção de alimentos, e cerca de $70 \%$ dos alimentos no mundo ainda são produzidos por camponeses, pois o modelo do agronegócio compreende apenas uma forma de se apropriar do lucro dos bens agrícolas, não se importando em solucionar os problemas de abastecimento alimentício da população.

A agricultura familiar ainda hoje é amparada pelo Estado, que busca mediar seus interesses econômicos e a necessidade de autonomia de famílias e pequenos proprietários, através da Secretaria da Agricultura Familiar, elaborando programas e investimentos voltados para o abastecimento de mercados internos, assim como a inserção da produção familiar aos complexos agroindustriais. Para além do SNCR, em 1966, foi criado posteriormente, em 1996, o PRONAF - Programa Nacional de Fortalecimento da Agricultura Familiar, com o intuito de financiar projetos de desenvolvimento de pequenos proprietários através de custeio e financiamentos àqueles com pouca disponibilidade de acesso aos recursos disponíveis. 
A partir de 2003, vários programas voltados para a agricultura familiar foram implantados pelo governo federal, como o Programa de Aquisição de Alimentos (PAA), de 2003, considerado uma das principais ações estruturantes do Programa Fome Zero ${ }^{119}$; o Programa Nacional de Alimentação Escolar (2009), voltado para o fornecimento de gêneros alimentícios às escolas da rede pública de ensino; o Programa de Garantia da Atividade Agropecuária da Agricultura Familiar e Seguro da Agricultura Familiar - PROAGRO/SEAF, que busca assegurar o produtor com garantia de renda; o Programa de Garantia de Preços para a Agricultura Familiar (PGPAF), que proporciona às famílias agricultoras um desconto no pagamento de financiamentos, em caso de baixa de preços no mercado; e o Programa Nacional de Crédito Fundiário (PNCF), que oferece condições para que os trabalhadores rurais sem terra ou com pouca terra possam comprar um imóvel rural através de financiamentos. Contudo, KLAUSER (2013) aponta que a lógica do crédito rural não corresponde à necessidade de oito milhões de famílias de agricultores, pois apenas um milhão têm acesso ao sistema de crédito oferecido.

O grande latifúndio se tornou o principal meio de territorialização da agropecuária nacional, correspondendo a 56,1\% das terras agrícolas do país, conforme visto no gráfico 3. Nas fronteiras agrícolas, a concentração de terras através de latifúndios é expressivamente maior, como nos casos das regiões Norte e Centro-Oeste, conforme mostra a tabela 7. Ela mostra que, por mais que existam políticas públicas no que diz respeito à reforma agrária, grande parte das terras ainda é concentrada em grandes latifúndios, que possuem a maior parcela dos valores de receita e produção nacional.

Dado tal contexto, a reforma agrária abarca essa discussão e ganha papel fundamental no que tange à estrutura fundiária brasileira, pois se torna inevitável a discussão sobre o conflito entre a concentração fundiária e a redemocratização da propriedade da terra, visto que tal redemocratização contribui para a redução da pobreza (presente no ambiente urbano), oferecendo a propriedade da terra a pequenos agricultores, reincorporando-os à esfera produtiva, colaborando para uma reestruturação da balança comercial, reduzindo a necessidade de importação de alimentos e, consequentemente, o preço dos alimentos a ser pago pela população.

A luta pela redemocratização da terra, portanto, trata-se de um antagonismo ao atual modelo de concentração fundiária sob o controle
119. CONAB. A Importância da Agricultura Familiar no Desenvolvimento dos Municípios. Maio de 20013. Disponivel em: <http://i-uma.edu.br/blog/2013/05/aimportancia-da-agricultura-familiar-no-desenvolvimentodos-municipios/>. Acessado em 16/062014. 


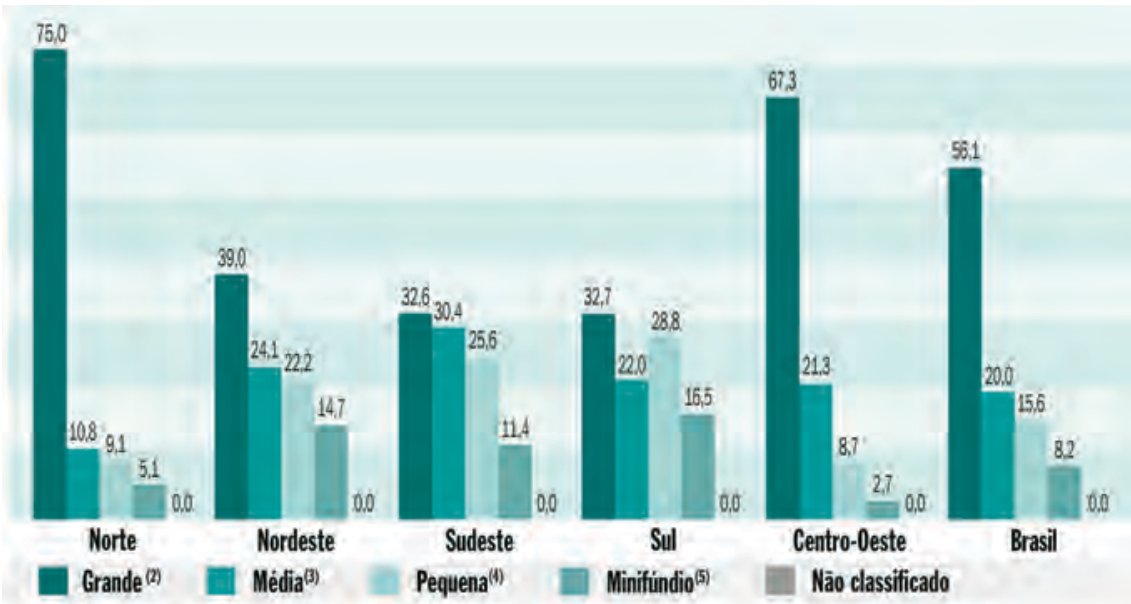

En Fonte: incra. Estatisticas Cadastrais, Elaboraçao: DIEESE

Nota: (1) 0 conceito de "imovel rural" definido pelo incra se encontra no glossário; (2) imóvel rural de area superior a 15 (quinze) módulos fiscais: (3) Imovel rural de área superior a 4 (quatro) e até 15 (quinze) módulos fiscas; (4) Imóvel nual de áreá compreendida entre 1 (um) e 4 quatro) módulos fiscais; (5) Imóvel rural com área inferior a 1 (um) móoulo fiscal.

Obs. 0 Incra exclui 273.849 imóves com dados inconsistentes: imóveis com área total menor que $99 \%$ do somatóno das areas exploradas, resenva legal, presensaça permanente, inaproveitavel e aproveitavel não utilzada; imóves com area total maior que $105 \%$ do mesmo somatonio
Gráfico 3 - Distribuição da área total dos imóveis rurais (1) por categoria - Brasil e grandes regiões (2009).

Fonte: DEPARTAMENTO INTERSINDICAL DE ESTATÍSTICA E ESTUDOS SOCIOECONÔMICOS, Estatísticas do meio rural, p. 31, ed. 4, Ministério do Desenvolvimento Agrário. Brasília, 2011.

\section{Caracterisiticas}

\section{Número de estabelecimentos}

Área (milhóes ha)

Máo de obra (milhóes de pessoas)

Valor da produçāo (R\$ bilhöes)

Receita (R\$ bilhoes)

\begin{tabular}{|c|c|c|c|}
\hline \multicolumn{2}{|c|}{ Agricultura familiar } & \multicolumn{2}{|c|}{ Agricultura não-familiar } \\
\hline Valor & Em\% & Valor & Em\% \\
\hline 4.367 .902 & 84,0 & 807.587 & 16,0 \\
\hline 80,3 & 24,0 & 249,7 & 76,0 \\
\hline 12,3 & 74,0 & 4,2 & 26,0 \\
\hline 54,4 & 38,0 & 89,5 & 62,0 \\
\hline 41,3 & 34,0 & 80,5 & 66,0 \\
\hline
\end{tabular}

(- Fonte: DEL GROSSI, M.E.

Elaboracáo: DIEESE

Nota: (1) Conforme a le in ${ }^{0} 11.326$
Tabela 7 - Características dos estabelecimentos agropecuários, segundo a classificação de agricultura familiar-Brasil, 2006.

Fonte: DEPARTAMENTO INTERSINDICAL DE ESTATÍSTICA E ESTUDOS SOCIOECONÔMICOS, Estatísticas do meio rural, p. 41, ed. 4, Ministério do Desenvolvimento Agrário. Brasília, 2011. 
de grandes empresas que visam ao aumento do número de exportações de grãos e, consequentemente, ao aumento de importações de alimentos básicos, que poderiam ser cultivados dentro do território nacional, barateando a produção de alimentos e reinserindo os pequenos e médios produtores na cadeia produtiva. Os conflitos surgem ao se esbarrar, de um lado em agricultores sem terras e na redução do preço dos alimentos para a população; de outro lado em interesses de grandes redes de importação e redistribuição de alimentos pelo território nacional e em interesses de latifundiários (que necessitam da totalidade de suas terras para produzir conforme a dinâmica internacional, de modo a aumentar seus ganhos).

O empresário agrícola acaba privando a população de alimentos, auferindo lucros com a negociação de commodities para grandes empresas transnacionais que atuam na agropecuária (como Monsanto, Bunge, Syngenta e Cargill, que detêm aproximadamente $58 \%$ da produção e comercialização mundial de gêneros alimentícios ${ }^{120}$ ), enquanto as grandes redes de supermercados com atuação no território brasileiro buscam obter maiores lucros com a revenda de importações. De acordo com KLAUSER (2014), esse controle do mercado pelas multinacionais é outro aspecto complicado, porque redes varejistas como Carrefour, Walmart e Pão de Açúcar passaram a controlar os processos de distribuição e comercialização e a definir o preço dos alimentos através de regulações do próprio mercado financeiro, auferindo maiores lucros no repasse de alimentos com base na exploração do pequeno agricultor, mantendo o preço de compra da produção bastante baixo, o que representa um grande risco para os agricultores (responsáveis por $70 \%$ da produção de alimentos brasileira).

Assim, a fronteira entre cidade e campo se diluiu, face às características da sociedade urbana que, com todo o aparato tecnológico e de comunicação e com as novas estratégias de acúmulo de capital, permitiram a reestruturação das relações socioeconômicas entre campo e cidade, subordinando aquele a esta última, permitindo-se falar de áreas de produção agrícola subordinadas a uma determinada atividade urbana financeirizada (apesar de alguns ramos da produção agroindustrial ainda dependerem da manutenção de pequenos proprietários agrícolas e até mesmo de organizações familiares). A organização do trabalho do agricultor não é mais voltada para subsistência. Mesmo que em alguns casos o trabalho siga uma estrutura familiar, está inserido em uma divisão social urbana do trabalho, seguindo os moldes de uma
120. SHIVA (2013). Com enfoque na produção e comercialização de soja, milho, canola e trigo, matérias primas essenciais para sua produção de alimentos industrializados, tais empresas têm como uma das bases fundamentais em sua atuação investimentos em biotecnologia e no patenteamento de sementes e defensivos agrícolas, que Ihes permitem o recolhimento de royalties através da comercialização dessas pequenas commodities. São as mesmas empresas que controlam a oferta e comercialização das sementes que produzem agrotóxicos e modelos biotecnológicos, controlando a produção alimentícia em diversos níveis. 
empresa ou indústria como outra qualquer, que compõe o padrão de produção urbano. Segundo KARNOPP e OLIVEIRA (2012), o agricultor (pequeno produtor ou família) não possui controle do processo, pois está inserido no sistema do agronegócio, que é o que controla toda a cadeia produtiva. Tal condição de subordinação se caracteriza na dependência em relação ao sistema, influenciando na escolha do que será produzido, no processo de produção, destino e comercialização dos produtos. Não há escapatórias: a agricultura familiar, apesar de compor um sistema diferente de organização e divisão social do trabalho interno à propriedade, é componente do sistema e do território do agronegócio.

De fato, a agricultura familiar e a agroindústria estabelecem conflitos no que tange à relação de confronto de interesses com os latifundiários, às políticas públicas, aos recursos financeiros e naturais e às relações sociais de produção. A principal diferença é que a agricultura familiar, para manter seu preço competitivo com relação à produção de grandes empresas e conservar-se frente às dinâmicas de mercado, necessita a intervenção e ação do Estado, pois ele é o elemento decisivo para que famílias e pequenos agricultores se desenvolvam e ampliem sua capacidade produtiva, mantendo-se na produção agrícola nacional através de medidas financeiras e de securitização, incorporando-a aos circuitos financeiros, de mercado e de produção ${ }^{121}$. Tanto a agricultura familiar quanto a agroindústria, por fim, estão profundamente inseridas e articuladas nas redes de produção e consumo agropecuário nacional e no agronegócio mundial ${ }^{122}$.

122. A questão trata de regulação e de intervenção do Estado para além da pura e simples competição de mercado. Um Estado que assessora e ancora as empresas a favor do mercado não teria assim por que intervir a favor da agricultura familiar - essas dimensões recolocam a necessidade de discussão das questões e problemas de análise a respeito das relações entre Estado e mercado, da relação entre as dimensões políticas e dimensões econômicas em relação ao campo da produção da agricultura familiar. 



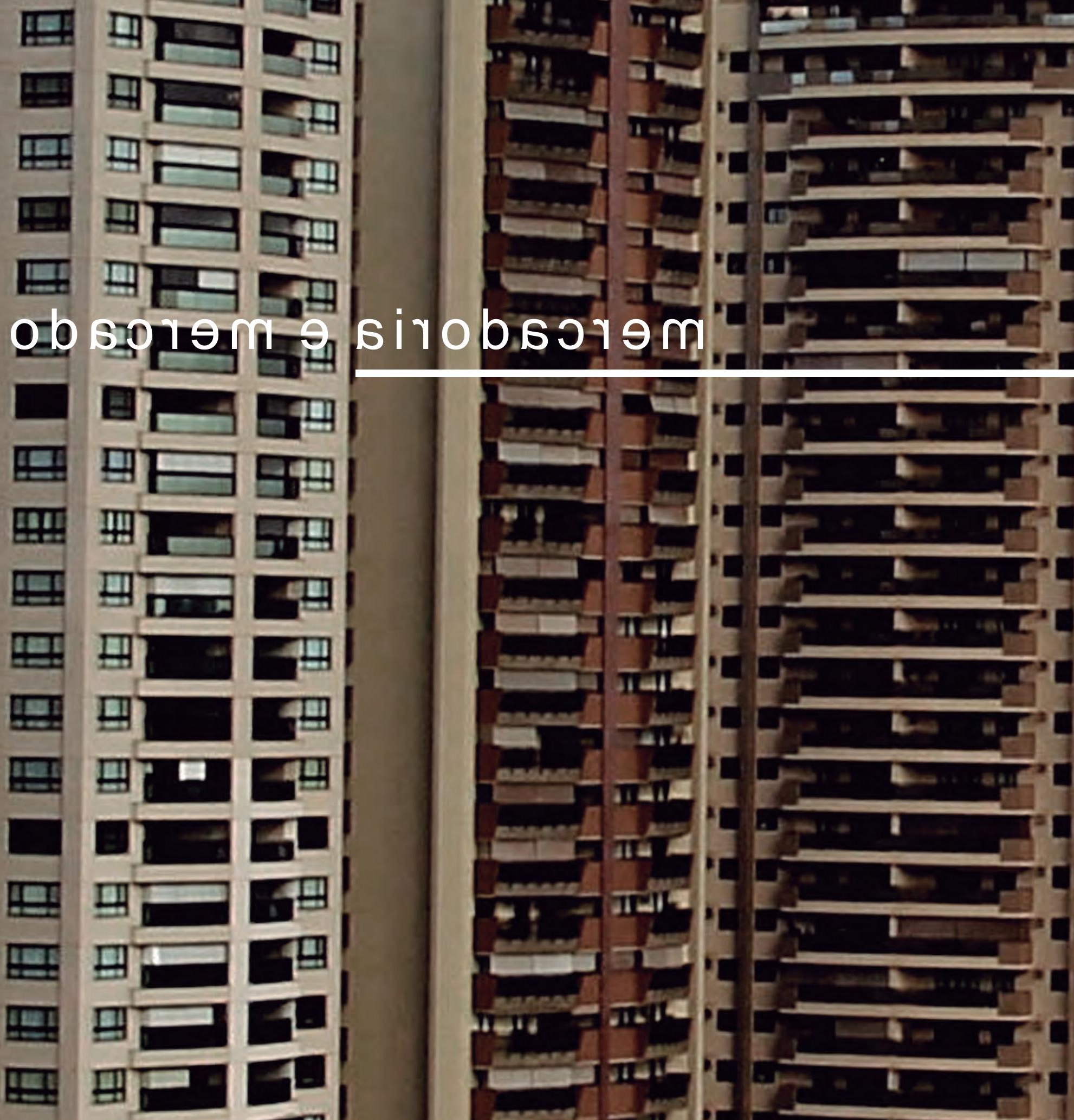


mercadoria e mercado 
DINÂMICAS ENTRE MERCADOS

As inovações financeiras, tendo como marco fundador a crise de 1970, conferiram grande importância ao capital financeiro em estratégias de reprodução do capital, principalmente as ligadas à securitização de ativos de empresas (titularização de dívidas, envolvendo e interligando mercados creditício, de capitais e de derivativos como swaps, opções e futuro, tendo como base partilhar o risco e gerar a falsa impressão de que o mesmo desaparecera ${ }^{123}$ ) e das dívidas estatais ${ }^{124}$. Com a industrialização do campo, expandiram-se também para o setor agrícola o fornecimento do crédito de investimento e custeio através de bancos e empresas privadas, e a comercialização da produção através de tradings e corretores, articulando-se produção agroindustrial e mercado financeiro, por meio da participação de grupos bancários que estabeleceram linhas de investimentos e fornecimento de crédito para a produção no setor.

Além das negociações das mercadorias, os bancos também passaram a estipular algumas exigências e certas metas que, caso não fossem cumpridas, contribuiriam para o endividamento de usinas e empresários do setor, formulando e estreitando relações de dependência financeira a grupos fora da esfera produtiva. Tal endividamento mos- 
trou-se bastante alto por conta da crise no setor, conforme dados de investimentos do Itaú BBA $^{125}$ : das 63 companhias sucroalcooleiras que receberam investimentos do banco, apenas 19 conseguiram chegar ao fim da safra de 2012/13 com saldo positivo, graças a um bom desempenho operacional e não estritamente em virtude dos preços do açúcar e do etanol.

Segundo FREDERICO (2011), os fluxos financeiros passaram a desencadear um papel importante por antecederem e serem fundamentais à produção, uma vez que os processos de exportação buscam exigir a aquisição de vultosos créditos para investimento, custeio e comercialização por parte de produtores e empresas privadas. Além da tradicional oferta de créditos pelo Estado, através de bancos públicos, vários bancos privados e cooperativas de crédito e outras empresas passaram a contribuir para os investimentos no setor, com o surgimento de novos agentes financeiros atuando lado a lado com os bancos privados - fundos de pensão e de investimento, seguradoras e fundos ligados a grandes corporações. Ocorreu, assim, uma alteração na hierarquia e no papel das instituições atuantes no mercado financeiro. Até o início dos anos 2000, cabia ao Estado a maior parcela dos financiamentos da produção agrícola. A partir da segunda metade da década, o financiamento privado passou a deter maior parcela dos investimentos no nexo financeiro da produção.

Os bancos rapidamente se difundiram pela região de Ribeirão Preto, num processo que se iniciou na década de 1980, através de políticas do Banco Central de incentivo à implantação de agências fora das capitais. Representaram agentes básicos para a expansão da rede de telecomunicações e informações, financiando a produção e a reorganização do espaço, e apresentaram-se como agentes financeiros da manifestação do consumo, com o oferecimento de créditos. A regulação financeira fora essencial para o vigor da modernização da região, já que o crédito se tornou instrumento vital para a inserção da região na lógica de produção e trocas globalizadas. A expansão do setor financeiro na região foi tanto uma condição para a difusão de novos padrões de produção, circulação e consumo, como consequência de uma modernização da economia ${ }^{126}$. A instalação de instituições financeiras estrangeiras para a região enfatizou mercados regional e global, tendo em vista o interesse de tais instituições em grandes empresas de exportação da região, consideradas filões mais lucrativos. Só na cidade de Ribeirão Preto há cerca de 120 terminais de serviços bancários, dentre agências
125. O Itaú BBA é o maior corporate \& investment bank da América Latina e faz parte do grupo Itaú Unibanco, um dos maiores conglomerados financeiros do mundo.

126. ELIAS, 2003, p.227. 
127. Fonte: Guia de cidades. Disponível em: <http://lw135421409050b7a202.hospedagemdesites.ws /categoria107-bancos-agencias-bancarias-e-pabs.html acesso em: 25/11/2013> e caixas eletrônicos ${ }^{127}$. Deste modo, o número de agências bancárias em uma cidade permite uma leitura da importância daquela cidade enquanto polarizadora e concentradora de fluxos de capitais e de pessoas, destacando-se na regulação da produção regional e da presença e atuação do capital financeiro. As instituições bancárias facilitaram e permitiram o acesso a financiamentos para investimento, custeio e comercialização da produção. Outro elemento atrelado ao número de agências bancárias nas cidades é a presença de escritórios comerciais de grandes tradings, ou exportadores, através dos quais eram e ainda são feitas as transações e comercializações de toda a produção agrícola, fornecimento de empréstimos aos produtores e importação de insumos, estabelecendo-se enquanto pontos importantes de conexão de uma rede articuladora de cidades para o agronegócio, principais centros exportadores, centros financeiros do país, bolsas de valores (como a CBOT de Chicago) e países importadores de commodities agrícolas.

As transações predominantes no agronegócio passaram a ser realizadas no mercado de commodities, nas bolsas de mercadoria em mercado à vista e/ou futuro, através da rede mundial de comunicações e circulação de informações em tempo real, operando em uma rede global de interações que transcendem fronteiras geográficas e nacionais. Grande marco da articulação da produção agrícola ao mercado financeiro está na abertura de capital da SLC Agrícola. Empresa da família Logemann, fundada em 1977 pelo Grupo SLC, produtora de commodities agrícolas, focada na produção de algodão, soja e milho e, em menor escala, na produção de café, cana-de-açúcar e trigo; atuando em seis estados brasileiros, foi a primeira fazenda de grãos do mundo a ter suas ações negociadas em bolsa, em 2007, com uma oferta pública inicial (IPO) de R 294 milhões. Depois dela, outras grandes corporações abriram seu capital na bolsa, como a Agrifirma, Adecoagro, BrasilAgro, Tiba, Agrinvest, CalyxAgro, El Tejar.

De acordo com ARRUDA (2013), no mercado à vista os produtores conseguem escoar a produção já colhida e em estoque, comercializando-os conforme os preços formatados de acordo com a posição do mercado (safra, entressafra e supersafra), de seu nível de demanda (seja do interno ou do externo) e a qualidade do produto. É através de tal mercado que instituições do governo regulam estoques e atendem a emergências do mercado. Já no mercado de futuro são negociados contratos a preços estabelecidos pelos contratantes, de modo que não há produto a ser comercializado, mas as transações ocorrem na expecta- 
tiva futura de comportamento do mercado para o produto.

O mercado de futuros abarcou tudo desde o comércio de direitos de poluição até especulações sobre o tempo. De quase nada em 1990, esses mercados cresceram e passaram a circular aproximadamente 250 triIhões de dólares em 2005 (a produção total mundial foi então de apenas $\mathbf{4 5}$ trilhões de dólares) e talvez algo como 600 trilhões de dólares em $2008^{128}$.

Um verdadeiro jogo de investimento, em que se comercializam títulos e não mercadorias, a priori - à exceção de contratos a termo -, de modo que supermercados, atacadistas ou agroindústrias compram safras futuras de produtores, que recebem dinheiro adiantado necessário à produção dos bens ofertados na bolsa. Neste tipo de mercado, existem as commodities agrícolas tangíveis transformadas num fluxo de mercadorias intangíveis e quantificáveis; e a commodity que é produto do capital transformado num fluxo de informação intangível e quantificável: os títulos (ARRUDA, 2013).

Como a produção se imbricou à dinâmica do mercado de valores, quaisquer alterações nesse mercado poderão gerar consequências relevantes à produção do espaço urbano nas cidades que possuem economia pautada na produção de commodities agrícolas. O capital financeiro, desse modo, atingiu o seu ápice dominando e comandando o mercado, a vida econômica e social no espaço urbano ${ }^{129}$, perceptível na questão do trabalho, no processo de reestruturação do arranjo produtivo e na concentração de investimentos em parcelas específicas das cidades e do território do agronegócio, seja para investimentos no consumo produtivo, seja para desenvolvimento do consumo consumptível e reprodução da cidade.

A cidade se tornou o locus de mediação entre a produção local e o mercado globalizado. As práticas comerciais revelam que a geração de riqueza nas atividades relacionadas ao agronegócio ocorre muito mais na área financeira do que na produtiva, sob o comando de grandes corporações, com apoio de cirandas especulativas. Obtêm-se lucros nas transações de compra e venda de safras, articuladas a cotações e preços fixados conforme a dinâmica de grandes mercados mundiais e da bolsa de mercadorias mundiais. Conforme ARRUDA:

As empresas que atuam no comércio de exportação beneficiam-se das vantagens locacionais, mas, os excedentes produzidos por essas corporações tendem a ser drenados dos campos e da região onde são produzidos, onde os custos de comercialização se

128. HARVEY, 2011, p. 26.

129. ARRUDA, 2013, p. 90. 
As fusões, aquisições, formações de holdings de empresas nacionais e a transnacionalização dos grandes grupos de capital, permitiram que tais grupos se livrassem de investimentos de longa duração, ganhando flexibilidade para explorar oportunidades lucrativas em qualquer outro lugar ou mercados (imobiliário, da construção civil, agropecuário, siderúrgico ou outro qualquer) do planeta, desde que fosse visto como alternativa viável de redução de custos ou ampliação de lucro. E não necessariamente os processos de fusão e aquisições ocorreram entre empresas exclusivamente do agronegócio: pelo contrário, uma associação no início dos anos 1980 entre Cutrale (citrícola) e o grupo Camargo Correa (construtora) gerou a Cutrale-Quintella Comércio e Exportação Ltda., que passou a cultivar soja no Mato Grosso. Em 1989, contribuíam com 30\% da soja total exportada e também inauguram o Bebedouro Shopping Center, incorporando lojas, supermercados e até um hotel quatro estrelas. Muitos outros grupos de setores diversos passaram a enxergar no agronegócio uma grande alternativa para investimentos e reprodução de capital, como o grupo Odebrecht.

Criado em 1981, o grupo brasileiro Odebrecht S. A., a holding da organização, teve origem no mercado da construção civil, voltado para grandes obras de infraestruturas e realizações imobiliárias, posteriormente expandindo sua atuação para diversos outros setores, como o de engenharia ambiental, energia, engenharia industrial, química e petroquímica, óleo e gás, transporte e logística e a mais recente expansão, o setor sucroalcooleiro. Sua estreia no agronegócio e no setor energético é relativamente recente. Através da fundação da Odebrecht Agroindustrial, em 2007, o grupo consolidou sua extensão para o agronegócio, tendo como foco a produção de etanol para comercialização às distribuidoras de combustíveis e para a indústria química e petroquímica. A produção de açúcar é totalmente exportada, e a energia de biomassa produzida garante a autossuficiência de setores da produção, sendo o excedente comercializado para o sistema elétrico nacional e para o mercado livre. Asede do setor agroindustrial da empresa se localiza em São Paulo e possui unidades de produção nos estados de São Paulo, Mato Grosso, Mato Grosso do Sul e Goiás.

Além da Odebrecht S.A., o agronegócio despertou o interesse 
de diversas outras empresas, como a Cantagalo General Grains, fruto da fusão entre a Agrícola Estreito, a trading Multigrain (da japonesa Mitsui) e a Coteminas, maior fabricante de artigos de cama, mesa e banho do país. Essa concentração e oligopolização do setor correspondem a uma lógica financeira pautada na atração de capitais excedentes, como o exemplo da fusão entre Vanguarda (produtora de algodão e soja) e Brasil Ecodiesel, visando a atrair o interesse de investidores chineses que buscam estabelecer acordos apenas com grandes empresas, buscando uma aproximação com negócios no Brasil, maior participação no mercado de alimentos mundial e atendimento da necessidade alimentícia do mercado chinês.

Assim, é possível notar que muitas empresas oriundas de outros setores produtivos expandiram seus negócios para o setor agropecuário, com o intuito de ampliar o controle da holding nos diversos níveis de produção, concentrando o capital, visto que o Estado não mais regulava o mercado e a produção sucroalcooleira. Notou-se um "apadrinhamento" do setor por parte de corporações de outros segmentos do agronegócio, e até mesmo de fora dele, com a diferença de que a produção açucareira passou de "carro-chefe" (até os anos 1980) para "outra alternativa" de reprodução de capital. Apesar da crise no setor, as grandes empresas com rendas consolidadas em outros segmentos não sofreriam tanto com a baixa dos preços do açúcar e do álcool. Em contrapartida, muitas empresas do setor agropecuário e agroindustrial também expandiram seus interesses para outros mercados, sobretudo o imobiliário. Para os usineiros e pequenos proprietários que não têm outras formas de investimento senão o arrendamento da terra às grandes corporações, ou, nos casos de proximidade da mancha urbana, a alteração do uso do solo para atender à dinâmica de mercados imobiliários, o negócio passou a ser visto como uma alternativa viável - quiçá vantajosa -, ainda mais com a produção de uma commodity que tem enfrentado grandes crises de precificação e de um combustível que carece de incentivos para geração de uma demanda.

O processo de formação e consolidação da LG Agro ilustra fortemente a relação entre mercado financeiro e agronegócio em escala internacional e mercado imobiliário. A empresa avançou na cadeia do agronegócio, disputando o espaço controlado por grandes tradings, através de um modelo que engloba quatro áreas de atuação: produção de açúcar e álcool (em 2011 possuía uma usina em operação e duas em
COMMODITIES AGRÍCOLAS E MERCADORIAS URBANAS 
131. A Los Grobo Agropecuaria foi fundada pelo empresário argentino Adolfo Grobocopatel em 1984. Possui sua rede de atividades divididas em três áreas de negócios principais: produção agrícola, insumos e venda de serviços. Em 2001, incorporou uma divisão industrial à sua carteira de produtos e serviços, estabelecendo a Molino LGI SA em Bahía Blanca, Argentina, bem como a rede de moinhos que inclui Molino Canepa (Chivilcoy) e Rosario de Tala (Entre Rios), e a Los Grobo Agroindustrial do Brasil, moinho, produtor e distribuidor de farinha no Brasil. A partir de 2003, a companhia fortaleceu seu processo de internacionalização reforçando sua presença no Brasil e Uruguai. Atualmente é um dos maiores produtores de grãos e prestadores de serviços da América do Sul (Informações extraídas de: LOS GROBOS, site do grupo. Disponível em: < http://www.losgrobo.com/pt/aboutgrupo-los-grobo/history.html > Acessado em 27 de julho de 2014). execução), produção de grãos em fazendas arrendadas (soja, milho e trigo), serviços (consultoria, comércio, distribuição, armazenagem e financiamentos a pequenos agricultores) e atuação no mercado imobiliário, através da compra e venda de terras. A empresa é resultado de um grande processo de fusão entre empresas que já exerciam tais atividades separadamente: o grupo Los Grobo ${ }^{130}$, a Sollus Capital, a Companhia Mineira de Açúcar e Álcool - CMAA (originalmente controlada pelo Pactual Capital Partners, JF Citrus e o fundo americano ZBI Ventures) -, e a Vinci Partners. Assim, passou a controlar toda a cadeia produtiva, da aquisição de terras e da produção de insumos, até a chegada aos mercados consumidores. Em 2011, a empresa estudou a possibilidade de abertura de seu capital na FM\&BOVESPA, de modo que os recursos obtidos fossem utilizados para a aquisição de terras, companhias, capital de giro e edificações e aquisições de máquinas e equipamentos. Contudo recuou, devido a análises do panorama do mercado financeiro brasileiro.

A LG Agronegócios e Participações S.A. tem como sócios a família argentina Grobocopatel, controladora do grupo Los Grobo, e a Vinci Partners, gestora formada por ex-sócios do Banco Pactual. Dentre eles está o banqueiro brasileiro Gilberto Sayão, proprietário de cinco fazendas de gado de corte e de grãos no Centro-Oeste e da PDG Realty - uma das maiores incorporadoras de capital aberto atuantes no mercado imobiliário do país, investindo também em outras sociedades nos setores imobiliário e da construção civil. Com isso, é possível identificar o processo de transnacionalização e da entrada de grandes corporações no setor agropecuário, bem como a articulação de tais esferas com o mercado imobiliário.

No estado de São Paulo, além da capital, o grupo PDG Realty possui negócios nas cidades de Campinas, São José dos Campos e Ribeirão Preto. Nesta última, fazem parte do portfolio da empresa o residencial Buona Vita (loteamentos de $250 \mathrm{~m}^{2}$ ), Buona Vita Siena (loteamentos a partir de $360 \mathrm{~m}^{2}$ ) e residências nos empreendimentos Praças do Sul, Recantos do Sul e Vivendas do Sul. Tais empreendimentos localizam-se na região sul de Ribeirão Preto, onde se concentram inúmeros lançamentos imobiliários destinados a classes mais elevadas, como o eixo da avenida Prof. João Fiúsa, e condomínios residenciais de alto padrão como o Vila dos Ipês, Vila do Golfe, Iguatemi, Terras de San Gabriel, Ipê Branco, Quinta da Primavera dentre outros. Tais condomínios são incorporações do grupo WTB, um dos mais influentes no mer- 
cado imobiliário na região, destacando-se pela produção de empreendimentos de alto padrão. Azona sul de Ribeirão Preto tornou-se o principal eixo de expansão das classes média e alta, concentrando os shoppings e demais instalações de consumo consumptível destinados às classes mais abastadas.

É importante destacar que grande parte da produção imobiliária na região está associada a incorporadoras locais, em conjunto e parceria com empresas do ramo de outras regiões, sobretudo da capital paulista. O residencial Bella Città (ver figura 19), em Ribeirão Preto, é produto de um consórcio investidor formado, de um lado, pela MAB Empreendimentos (do grupo WTB), Grupo LDI, Cipasa Urbanismo, Scopel Desenvolvimento Urbano - estes todos com suas sedes na capital paulista - e pelo outro, Vila do Ipê Empreendimentos e MRD Empreendimentos Imobiliários, representante da família proprietária da gleba.

A construtora e incorporadora Stéfani Nogueira também é uma das mais atuantes no setor da construção civil e no mercado imobiliário da região. Responsável pela construção dos residenciais Torino, Milano e Verona (ver figura 18), o grupo possui sua área de atuação focada em Ribeirão Preto, porém realiza empreendimentos em outras cidades não apenas da região, como Barrinha, Serrana, Sertãozinho, Jaboticabal e Guatapará, mas também de outras regiões do estado, como Bariri, Barretos, Ilha Solteira, Batatais; e de outros estados, como Mato Grosso do Sul, Minas Gerais e Goiás.

Toda a profusão de empreendimentos imobiliários na cidade e na região de Ribeirão Preto é decorrente do processo de aglomeração sofrido pela cidade, ocasionado pela agroindústria e o agronegócio, que estabeleceram grandes fixos de consumo na região, inserindo-a no mapa de investimentos externos e, ao mesmo tempo, reproduzindo o território urbano. A inserção da região de Ribeirão Preto na divisão internacional do trabalho para a produção de importantes commodities reconfigurou as relações sociais, atividades econômicas e o próprio território, permitindo a ampliação da produção regional e sua conexão com nexos distantes. Isto reconfigurou os chamados círculos de cooperação. A existência e predominância de empresas e serviços no território passou a exercer certa hegemonia no setor agropecuário, desencadeando o processo de urbanização de cidades corporativas, fazendo da região um lugar globalizado, revelando-a aos interesses de grandes agentes hegemônicos contemporâneos, da economia, da sociedade e

123. HARVEY, 2013.

124. REIS, 2007. 

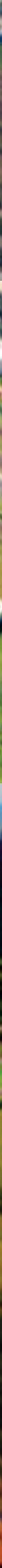

Figura 19-Condomínio Bella Città. Segundo a empresa, todos os lotes foram vendidos em menos de um mês, apontando a dinâmica acelerada do mercado imobillário-em Ribeirão Preto. Fonte: Grupo WTB (divulgação).

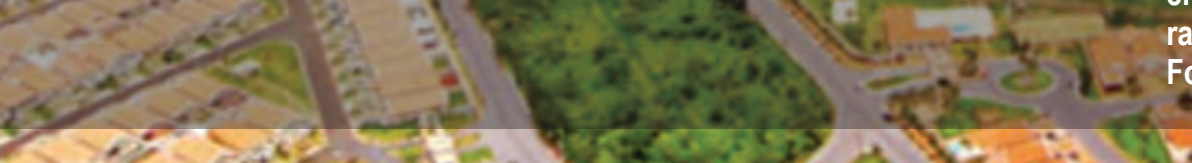

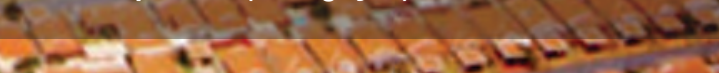


de grandes holdings, e incorporando-a às correntes da globalização.

$\mathrm{Na}$ ausência de quaisquer limites ou barreiras, a necessidade de reinvestir do capitalista impulsiona o capitalismo a se expandir (HARVEY, 2011). Isso cria a necessidade permanente de busca por novos campos de atividade para extração de capital reinvestido, justificando a expansão do território agrícola brasileiro e a conformação dos arranjos produtivos; a reestruturação que se inicia com a urbanização, através da atuação do mercado imobiliário, produzindo mercadorias a serem valorizadas dentro de uma dinâmica articulada com o crescimento urbano; e a alteração de uso do solo por parte de latifundiários, articulada com os avanços da biotecnologia, permitindo uma manutenção da produção agrícola enquanto se criam novas oportunidades para a acumulação de capital através de loteamentos e urbanização de áreas de produção agrícola. A urbanização permite, assim, a ampliação da oferta de bens básicos para suprir o crescimento populacional, correspondendo a "uma forma de absorver o excedente de capital" empregando uma significativa força de trabalho na reprodução do urbano enquanto mercadoria, através da construção e manutenção de empreendimentos. $E$ tais projetos só podem ser mobilizados reunindo grande poder financeiro e envolvimento do Estado, reforçando ainda mais o nexo Estado-finanças-capital, através de uma relação em que "não só os investimentos do Estado se pagam por si mesmos, mas também geram uma receita extra para ser aplicada em mais infraestrutu-

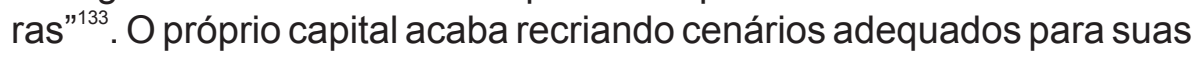
necessidades, através da reorganização do território em arranjos produtivos, da reprodução da ideologia de consumo, do ideário da casa própria e até mesmo com programas públicos de construção de habitação, providos pelo Estado, produzindo as condições necessárias para a realização da urbanização.

A cidade e a região passaram a ser vistas enquanto grandes empresas, onde se distribuem recursos, consumo e populações, ao serem reestruturados os arranjos produtivos (dada a alteração para um regime de acumulação flexível) e as forças produtivas do trabalho. Cada cidade passou a buscar um papel e, caso sua gestão não conseguisse administrá-la corretamente, de modo a atrair capital, correria grandes riscos de perder recursos para outras cidades. Deste modo, como Vainer conclui, a cidade assimilou um caráter empresarial, tornando-se locus dos negócios e da mercadoria, e tornando-se ela mesma um negócio. De acordo com HALL (1995), HARVEY (2011) e

132. HARVEY, 2011, p. 75.

133. Ibid., p. 77. 
KLINK (2001), a política urbana passou de um enfoque de gerenciamento de serviços urbanos para uma abordagem de empresariamento, destacando o papel de um número crescente de cidades-regiões e novos compromissos com geração de emprego e renda e políticas de atração de capital - atividade econômica e empresas para o território, como os complexos agroindustriais, setores de serviços, setores financeiros (concentrados em locais específicos da cidade, tendo em vista o desenvolvimento de uma espacialidade especializada em determinadas atividades) e a própria habitação.

\begin{abstract}
A construção de espaços, bem como a criação de uma morada segura chamada casa e lar, tem um impacto tanto na terra quanto na acumulação do capital, e a produção de tais lugares se torna um grande veículo para a produção e absorção do excedente. A produção do urbano, onde a maioria da população mundial em crescimento agora vive, tornou-se ao longo do tempo mais estreitamente ligada à acumulação do capital, até o ponto em que é difícil distinguir uma da outra ${ }^{134}$.
\end{abstract}

Conforme visto, com os complexos agroindustriais e a atuação de agentes estatais e de iniciativa privada no processo de territorialização do capital, os processos de acumulação do capital inexistem fora de contextos geográficos (HARVEY, 2011). Também estão relacionados ao crescimento da população: ao mesmo tempo em que se expandiu o mercado de produtores e consumidores para as dinâmicas capitalistas, a acumulação se constituiu enquanto forma de aprovisionamento para manutenção das populações.

Como é possível deslocar os fatores da produção, em virtude de melhores condições de trabalho, uma disputa entre cidades se desenvolveu, visando à atração de mão-de-obra qualificada, capital produtivo e capital financeiro ${ }^{135}$. É possível reconhecer o caráter empresarial da cidade, da região, do Estado, assumindo cada vez mais tarefas

134. Ibid., p. 122

135. KLINK, 2001, Neste aspecto, enxergar a região de Ribeirão Preto enquanto cidade-região nos permite averiguar que o desenvolvimento urbano das cidades está inter-relacionado, assim como o desenvolvimento do tecido urbano e a demanda por habitação, uma vez que algumas cidades são consideradas dormitórios, sendo que o trabalhador possui seu trabalho em outra cidade, ou em propriedades agrícolas, e regressa a cidade dormitório por ali o preço da terra ser mais vantajoso com relação à outras áreas da região. de geração de renda e emprego, buscando captar o escasso capital volátil, adotando estratégias de competição entre si, colocando a própria cidade e a região como novos objetos da administração de empresas. A volatilidade do capital e do trabalho Ihes possibilitou migrar entre as cidades, a fim de maximizar os lucros, buscando espaços para melhor reprodução do capital, tendo em vista as oportunidades de maior lucratividade e de grandes mercados consumidores para as empresas; da instituição de atrativos para a formação de mercados de consumidores e de profissionais, bem como a oferta de uma qualidade 
de vida urbana ideologizada (compreendendo questões de segurança, acessibilidade a equipamentos educacionais, de saúde, mobilidade urbana e habitação de qualidade), o que acabou por estabelecer elos entre global e local, e também entre consumo e uma forma empobrecida de espaço público ${ }^{136}$.

As empresas estabeleceram nas cidades o uso corporativo, transformando-a em um sistema prestador de serviços produtivos e familiares, em um locus da relação local-global, reorganizando o território local e regional, definindo espaços corporativos, de concentração de riqueza, fragmentados e de segregação explícita. As cidades que possuem uma maior divisão técnica do trabalho, exercendo determinada centralidade regional, destacam-se pela presença de profissionais ligados ao nexo administrativo, financeiro e logístico da produção.

A política de competitividade urbana possui duas dimensões fundamentais: seu "entorno", correspondendo aos aspectos mais tradicionais para a implementação das políticas, como redes de infraestruturas de comunicações, qualidade de serviços urbanos e tecnológicos, de mão-de-obra e meio ambiente; e seus "produtos", em função dos quais o sucesso das políticas e economias urbanas é avalizado em conjunto de resultados concretos para aumentar a produtividade urbana local. Cabe à cidade viabilizar ações para tornar isso possível, através da elaboração de sistema de informação sobre o mercado internacional, novas tecnologias, sistemas de distribuição e comercialização de insumos, pessoas e mercadorias ${ }^{137}$. Além disso, permite-se que a cidade incentive a instalação de equipamentos - como parques tecnológicos, espaços de feiras e convenções - que geram atividades de alto valor agregado, como também a responsabilizam por reduzir o "risco sistêmico" de empresas - característica intrínseca ao cenário globalizado - e construir uma autoimagem positiva como sendo "um espaço produtivo, agradável e seguro para a realização de negócios, por exemplo, através de campanhas agressivas de 'city marketing"'138 para atração de capital.

O mercado imobiliário entrou na sequência e passou a oferecer o produto habitação através de seus empreendimentos travestidos de sonhos e qualidade de vida, em uma cidade repleta de oportunidades de emprego, facilidades e lazer. Assim, as cidades geram imigrações de duas naturezas: uma população com condições de consumo para quem a infraestrutura é feita para seu desfrute; e outra de excluídos do consumo moderno, migrantes expulsos do campo, ou proveni- 


\section{SANTOS, 2006.}

140. Fonte: G1, Inauguração do shopping Iguatemi amplia mercado de luxo em Ribeirão. Disponível em: <http://g1.globo.com/sp/ribeirao-pretofranca/noticia/2013/09/inauguracao-do-shoppingiguatemi-amplia-mercado-de-luxo-em-ribeirao.html> acesso em: nov/2013. entes de regiões mais pobres do país, em busca de oportunidades de emprego e melhores condições de vida. Amplia-se a oferta e a procura por uma população trabalhadora mais qualificada ao mesmo tempo em que aumenta a população desempregada, subempregada e de trabaIhadores informais. Nesta situação, o indicador PIB per capita omite toda a desigualdade real e o verdadeiro acesso às infraestruturas urbanas.

As cidades se desenvolveram de modo a atender às demandas industriais e empresariais na região, configurando-se naquilo que SANTOS define como cidades corporativas, de modo que, mesmo que o crescimento econômico tenha sido considerável, geraram-se consequências sociais e espaciais tremendamente devastadoras.

Os novos empreendimentos urbanos passaram a apresentar escalas amplas, com produção seriada voltada para o mercado, estando estreitamente articulados com o mercado financeiro, utilizando-se de estratégias de marketing para rápida transferência das propriedades das unidades (mercadorias), como se pode analisar nas propagandas de lançamentos imobiliários que têm como foco a qualidade de vida, a localização e facilidade de acesso a equipamentos urbanos (ver figura 20). E isso é refletido também no desenho urbano que se produz de cidade que se vende sob a forma de loteamentos e grandes empreendimentos imobiliários, articulado ao viés moderno de planejamento e organização do território, usufruindo dos instrumentos de zoneamento. O desenho urbano vinculado à expansão e ao mercado imobiliário, deste modo, está estritamente relacionado à territorialização do capital, de modo que se estabeleçam os polos aos quais serão destinados investimentos, localizadas as agroindústrias, concentradas as atividades do setor financeiro, aglomeradas as empresas de comércio, reunidos os empreendimentos imobiliários para a classe média, ou deslocadas as populações de baixa renda.

Supermercados e shoppings, templos modernos do consumo por excelência ${ }^{139}$, surgiram na região, principalmente na cidade de Ribeirão Preto, em decorrência do aumento da demanda de consumo consumptível. Atualmente, a cidade possui quatro shoppings - Ribeirão Shopping, Novo Shopping, Santa Úrsula e Iguatemi. Este último, empreendimento incorporado pelos grupos WTB, Vila do Ipê e Iguatemi Empresa de Shopping Centers em Ribeirão Preto, prevê uma circulação diária de 20 a 30 mil visitantes ${ }^{140}$. Boa parcela do fluxo mensal de visitantes dos shoppings ribeirão-pretanos tem sua origem em cidades 
O FLAT QUE VOCÊ SEMPRE DESEJOU.

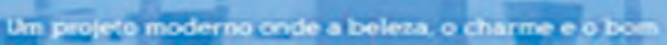

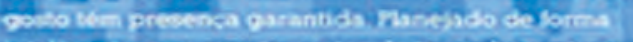

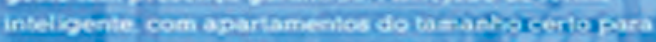
organitar o espeso do sed leito Aptowelted vida do forma que escoliner no Baia da Guanabara?

\section{UM PROJETO - COMPLETO.}

Con localiacabo peivilegiada no Alamedas do Bocanico, zona sul, morar po: Residencial Cabreciva e deslrutar de muitas vantagens: $O$ melhor projeto agora faz parte da sua vida.
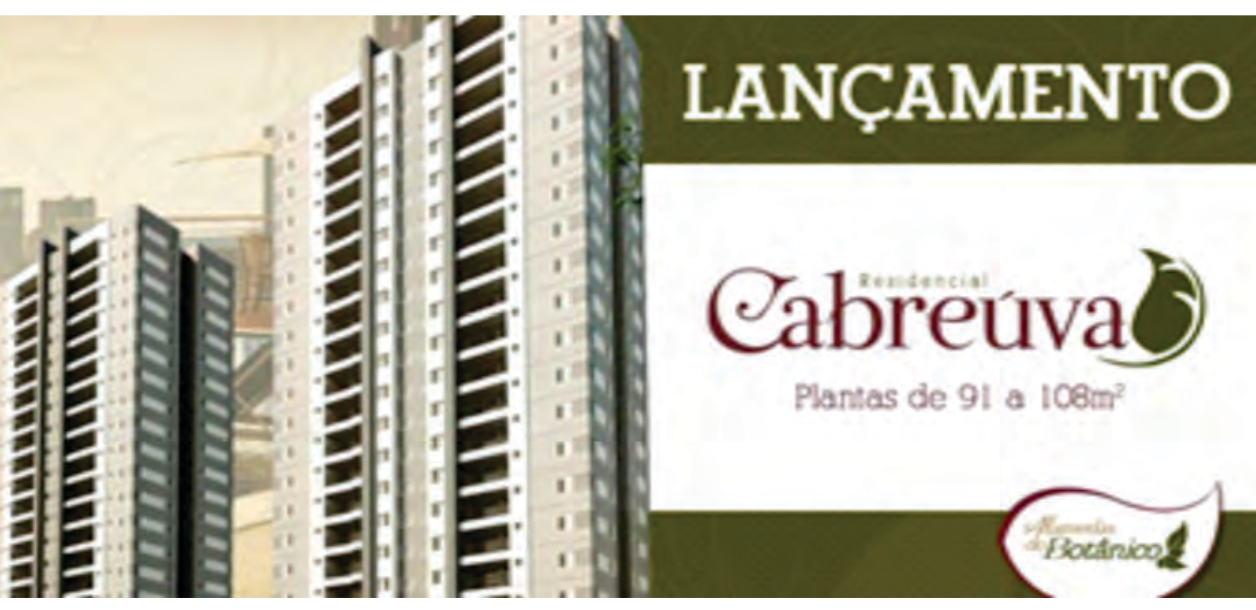

๙ह5 BARAÚNA
Seu grande projeto de vida กO CORACÄO DA CIDADE.
(B) PANPMBY
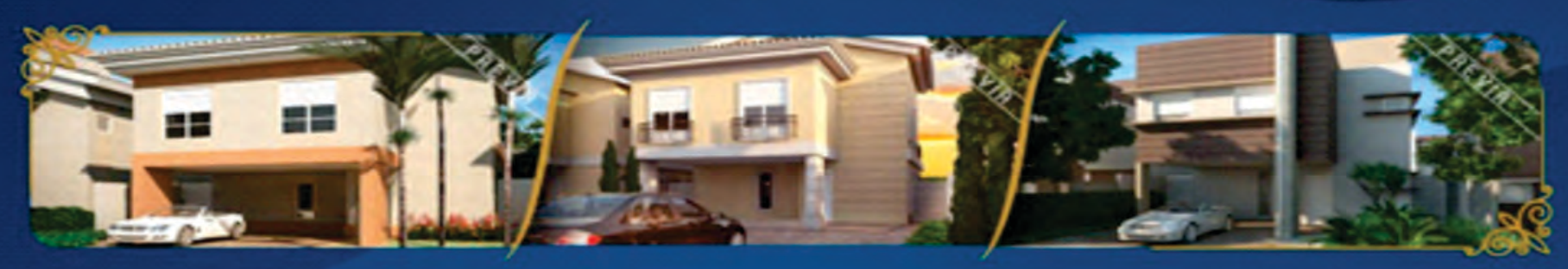

Figura 19-Peças publicitárias de Marketing imobiliário.

Peças de divulgação dos empreendimentos Baía de Guanabara, Residencial Cabreúva e Residencial Baraúna, em Ribeirão Preto. Destaque para a utilização de conceitos abstratos e localização privilegiada como vantagens do negócio. Fonte: Stéfani Nogueira (divulgação). 
141. Segundo ADORNO (1997), na indústria cultural, enquanto negócios, seus fins comerciais são realizados através da exploração de bens considerados culturais. 0 que antes era considerado um modo de lazer ou arte se tornou um meio eficaz de consumo. Ver: HORKHEIMER, M., e ADORNO, T. W. Dialética do Esclarecimento: Fragmentos filosóficos. Trad. Guido Antonio de Almeida. Rio de Janeiro: Jorge Zahar, 1997. localizadas num raio de até $100 \mathrm{~km}$, o que ELIAS (2003) considera uma característica importante para a consolidação do espaço regional, destacando o caráter polarizador da cidade de Ribeirão Preto e atraindo o interesse de empresas hegemônicas, pautadas na produção de empreendimentos urbanos e em investimentos no desenvolvimento de um setor terciário na região. O Ribeirão Shopping, por exemplo, é um empreendimento resultante da associação de importantes grupos econômicos que possuem outros projetos similares no país. Destaca-se, portanto, a reprodução da cidade com base em interesses mercadológicos - vide as modificações decorrentes no território após a consolidação da importância econômica de um equipamento centralizador como um shopping, iniciando-se um processo de produção de cidade focado na forte especulação imobiliária.

Com as novas formas de crédito e toda a reorganização socioterritorial que a região sofreu com a modernização da agroindústria, a relação entre cidade e campo se reconfigurou de tal forma que tornouse praticamente impossível a distinção entre ambas as esferas, do ponto de vista econômico e das relações entre fluxos e produção. Apesar das grandes alterações terem ocorrido na esfera do campo, a relação consiste em uma via de mão dupla. Por um lado a produção agrícola se tornou mecanizada: alterou-se a divisão social do trabalho agropecuário, de modo que o trabalho agrícola passou a reproduzir a mesma estrutura que o trabalho urbano; indústrias e as empresas foram levadas para o campo; o trabalhador do campo passou a ser um profissional regulamentado por uma legislação trabalhista urbana. Por outro lado, conforme visto, as lutas sociais por melhorias das condições de trabalho e reforma agrária das classes trabalhadoras do campo passaram a ser realizadas no ambiente da cidade, assim como a cultura sertaneja fora incorporada ao cotidiano das cidades que receberam tal população, através de festividades religiosas, da música de raiz, vestimentas, adoção de costumes e linguajares "caipiras". Muitas atividades, para além das relacionadas aos complexos agroindustriais, voltadas para o consumo da população da aglomeração, surgiram e se estabeleceram nas cidades da região, dentre elas o lazer propiciado tanto por essa assimilação de festividades sertanejas tradicionais (como o encontro de cavaleiros), quanto pela indústria cultural ${ }^{141}$, através do country e da figura do cowboy, em eventos como a tradicional festa do peão de Barretos.

A Festa do Peão de Boiadeiro de Barretos nasceu em 1956, 
como o primeiro evento do gênero realizado na América Latina, declarado em 1964 de utilidade pública e oficializado por Lei Estadual em 1964. Em 1967, o grupo Os Independentes, organizador do evento, adquiriu um patrimônio que, paulatinamente, foi sendo ampliado com a aquisição de uma gleba de 40 alqueires, em 1980, para a instalação do Parque do Peão, inaugurando, nove anos depois, o Estádio de Rodeios, projeto de Oscar Niemeyer. Fortemente influenciada pela cultura country norte-americana, Barretos adquiriu relevância internacional a partir de 1994, com a primeira edição internacional do rodeio, que contou com a presença de peões americanos, canadenses e australianos, o que permitiu à cidade de Barretos sediar uma das etapas da PBR - Professional Bull Riders -, evento de montarias de touros norteamericano. Em 1996, foram incorporados à área do Parque do Peão mais 10 alqueires. Atualmente, com repercussão internacional, a estrutura na cidade compõe o Calendário Mundial de peões de vários eventos internacionais.

Ribeirão Preto tem promovido, desde 1993, a Feira Internacional de Tecnologia Agrícola em Ação - AGRISHOW -, um dos eventos de maior magnitude do agronegócio brasileiro e uma das maiores e mais completas feiras de tecnologia agrícola do mundo, organizada pela BTS Informa e idealizada pelas principais entidades ligadas direta e indiretamente ao agronegócio brasileiro, como ABAG (Associação Brasileira do Agronegócio), ABIMAQ (Associação Brasileira da Indústria de Máquinas e Equipamentos), ANDA (Associação Nacional para Difusão de Adubos), FAESP (Federação da Agricultura e Pecuária do Estado de São Paulo) e SRB (Sociedade Rural Brasileira). Na 22a edição do evento, em 2014, reuniram-se cerca de 800 marcas expositoras, contemplando os mais variados setores da agropecuária, desde agricultura familiar, insumos agrícolas, fertilizantes, defensivos, equipamentos, máquinas e logística, atraindo mais de 160 mil visitantes. Além da exposição, a feira conta com uma área para demonstrações das grandes máquinas agrícolas em ação no campo, tal como diversas culturas - de arroz, café, cana, feijão, milho e outras de interesse de agricultores e investidores na região ${ }^{142}$.

Tal como a AGRISHOW, a Feira Internacional de Tecnologia Sucroenergética ocorre desde 1993, só que na cidade de Sertãozinho, levando o título de maior evento mundial em tecnologia e intercâmbio comercial para usinas e profissionais do setor sucroenergético, contemplando os setores agrícola, de fornecedores industriais, processos
142. 22 ${ }^{\mathrm{a}}$ FEIRA INTERNACIONAL DE TECNOLOGIA AGRÍCOLA EM AÇÃO. Sobre a feira. Ribeirão Preto, 2014. Disponivel em: <http://www.agrishow.com.br/>. Data de acesso: 08 de ago. 2014. 
143. Idem. Apresentação. Sertãozinho, 2014. Disponível em: <http://www.fenasucro.com.br/>. Data de acesso: 08 de ago. 2014.

144. ALENCAR e LANDIM, 2012, p. 3.

145. ELIAS, 2003, p.230. industriais, transporte e logística. É um importante encontro entre os principais fabricantes de equipamentos, produtos e serviços para a agroindústria da cana e os milhares de visitantes técnicos e qualifica$\operatorname{dos}^{143}$.

As cidades se tornaram espaços onde "o capital financeiro, dentro de um processo de seletividade espacial supranacional, encontrou condições de sobrevivência, atraído por políticas de incentivo legitimadas pelo Estado", com o apoio de forças locais e de arranjos produtivos espaciais ${ }^{144}$. Essa imagem foi reforçada através de tais exposições, feiras e rodeios, que têm articulado negócios agropecuários ao entretenimento e à reprodução da cultura country (considerada "grande signo da modernidade no campo brasileiro" ${ }^{145}$, por estar relacionada a uma indústria cultural em nível global). A ocorrência de eventos na região também passou a indicar uma ligação importante entre consumo produtivo, consumptível, negócios e agroindústria. Grandes empresas organizam desde a publicidade e o marketing e até locação de estacionamentos, em prol da atração de um grande número de visitantes, tanto aqueles especializados do setor - para negócios, trocas comerciais e prestação de serviços -, como os espectadores comuns, atraídos pelo entretenimento, alimentação e pela cultura do rodeio. Tais eventos passaram a injetar dezenas de milhões de reais na economia das cidades, uma vez que articulam diversos serviços durante suas edições, evidenciando o caráter financeiro por trás de todo o cenário de entretenimento.

O crescimento e a instalação de grandes empresas na região introduziram novas formas de produção, articuladas ao circuito primeiro da economia, novas formas de expansão do financeiro, de modalidades de planejamento, administração e marketing. Diante disso, a urbanização da sociedade e do território da região tem respondido às necessidades do mercado no território, de acumulação e concentração das grandes empresas. Os investimentos para a construção dos fixos foram aplicados de modo a privilegiar interesses econômicos empresariais, em detrimento dos interesses sociais. O resultado foi a concentração de riqueza, a difusão da pobreza pela superfície do território regional e, concomitantemente, a construção de um ideário de pertencimento às classes médias por parte de pequenos proprietários e profissionais relativamente qualificados em um espaço corporativo e fragmentado.

Os planos diretores e estruturas de regulação urbana, que outrora até poderiam possuir um viés de aplicação de políticas socioespaciais, cederam espaço a uma reprodução de cidade que passou a 
reinterpretar seu significado através da ressignificação de valores e o papel do "planejamento estratégico" enquanto reconstrutor de um novo sentido de cidade. Para isso, os eventos, demais aparatos culturais e serviços urbanos buscam influenciar positivamente os negócios de empresas ali implantadas, tendo como premissa ampliar a visibilidade da cidade para atração de capital volátil, promovendo vantagens do espaço local em relação a outras cidades e objetivando o desenho urbano enquanto fator fundamental no processo e no desenvolvimento de políticas econômicas ${ }^{146}$.

Conforme visto, se o uso da terra possuía um caráter social, produzido com tal finalidade, atualmente o caráter financeirizado das forças produtivas transparece na produção social do espaço, de modo que o espaço inteiro se configura como produto comerciável, através da compra, da venda e da troca de lotes. O espaço geográfico mundializado se redefiniu vertical e horizontalmente pela combinação de novos signos - mundialização de firmas e internacionalização dos produtos e da produção, novos papéis dos Estados, revolução dos meios de comunicação e de acesso a informações, generalização do crédito e circulação como caráter de acumulação.

Novamente, como tem sido notado, apesar de uma falsa ideia de homogeneização, gerada pela estrutura da rede urbana, as reestruturações operaram com diferentes efeitos e em diferentes escalas, desde blocos de poder (Europa, Bloco Asiático, América do Norte), passando por estados, regiões metropolitanas, governos regionais, cidades e municípios, aprimorando a noção de competitividade para formação de estruturas solidárias de captação do capital excedente e estando sujeitas à soberania de um povo, ou seja, dependentes de resultados de lutas políticas internas. A territorialização do capital transpassou fronteiras administrativas em todas as escalas, até mesmo as dos Estados, como o Fundo Monetário Internacional, Organização Mundial do Comércio e Banco Mundial, de modo que tais organizações passaram a ter papel cada vez mais importante na orientação de fluxos de capital e proteção da acumulação. A formação de blocos de poder supraestatais, como Mercosul, OTAN e União Europeia, indicam a tendência do estabelecimento de territórios acima e além do Estado nacional, em grande parte para fins econômicos ${ }^{147}$.

A urbanização das cidades do interior de São Paulo se deveu, dentre outros fatores, ao rearranjo territorial do capital, articulando cidades, ampliando e conformando uma rede urbana, redistribuindo as ativi-
146. O desenho urbano e a atividade produtiva escaparam quase que por completo aos planificadores e planejadores no capitalismo de organização. Apesar da participação legitimada dos tecnólogos e técnicos na discussão sobre planejamento urbano, não são eles que decidem, pois estão inseridos na figuração das relações de produção apenas cumprindo ordens. Executam obedientemente a simples commandes sociais, quando acreditam comandar o espaço. Ou seja, o arquiteto pensa em tratar o espaço urbano livrando-o de males (e amém!), quando na verdade todo o seu esforço é direcionado à confecção um produto supremo, objeto de troca para fins de mercado (as decisões projetuais se tornam vantagens de compra, criando fetiches, desejos e conquistando mercados consumidores). LEFEBVRE (1970) afirma que o capitalismo tornou toda iniciativa no domínio do urbanismo essencial para sua sobrevivência, através de uma estratégia que não apenas faz o espaço entrar na produção da mais-valia, como também visa uma reorganização completa da produção subordinada aos centros de informação e decisão. Deste modo, o urbanismo corporativo encobre toda a operação mercadológica, dissimulando valores e traços fundamentais, sentindo e finalidade, mascarando a estratégia de dominação do espaço sob uma aparência positiva, humanista e tecnológica. Tal urbanismo, objetivo na aparência, é de classe e encerra uma estratégia de classe, não passando de uma ideologia que se proclama arte, técnica e ciência, implicando em um duplo fetichismo: 0 da satisfação e o do espaço (KLINK, 2001, p. 143).

147. Segundo HARVEY (2011, p. 163), uma das principais transformações ocorridas no Estado após os anos 1970 também foi a descentralização de competências que passaram a ser atribuídas a governos regionais, metropolitanos e locais, permitindo assim os municípios e regiões gerirem os recursos e administrá-los com maior autonomia. 
dades pela região e reestruturando os modos de produção agrícola, concentrando determinados tipos de investimentos, de acordo com a atividade desempenhada para o sistema produtivo agroexportador. As cidades da região de Ribeirão Preto se expandiram rapidamente, espraiando-se, acompanhando o traçado dos eixos de circulação e gerando espaços vazios, propiciando a especulação imobiliária e a desigual valorização do espaço urbano. Os investimentos não foram distribuídos de maneira homogênea pelo território regional, nem mesmo no municipal, acumulando vantagens em áreas específicas, como a zona sul de Ribeirão Preto. Pode-se notar, através do diagrama, que o crescimento da malha urbana ribeirão-pretana se iniciou com a aprovação de loteamentos distantes uns dos outros e da área central e, em seguida, dando início a um processo de preenchimento dos "vazios", ocupados, na realidade, por loteamentos agrícolas, a partir do que hoje é conhecido como quadrilátero central. Durante a década de 1940, já se destacava com maior nitidez a extensão e ampliação da área central. O processo de alteração do uso do solo agrícola nas áreas entre redes urbanas permaneceu crescendo em uma velocidade constante até os anos 1980, quando o processo se intensificou e a produção de loteamentos aumentou consideravelmente com relação ao período anterior. No período entre 2010 e 2011, Ribeirão Preto já havia aprovado cerca de $30 \%$ do total de loteamentos aprovados durante toda a década anterior (ver tabela 8 de loteamentos aprovados no período).

Considerando-se que crescimento econômico e organização do espaço se retroalimentam, a construção das cidades corporativas se deu com a desigual distribuição de recursos no território, de forma que os modos de expansão da riqueza e da pobreza se refletem na construção do próprio espaço, através de sua composição orgânica refletida na organização interna das cidades, gerando cidades dispersas, com um crescimento desenfreado e um grande número de problemas urbanos, definindo uma hierarquia entre espaços que "mandam" e espaços que "obedecem", direcionando políticas públicas para determinadas áreas, beneficiando com recursos públicos parcelas específicas da cidade. Com toda sua gama de desequilíbrios e defasagens, dadas por uma divisão econômica da sociedade em classes, conforme estratos de renda, o espaço se reproduziu através de um modelo urbano extenso, disperso e corporativo, dotado de um agravante gerado pelo descompasso entre evolução econômica e social, inerente ao modelo capitalista. Em Ribeirão Preto se superpuseram riqueza e uma "gama de defa- 


\begin{tabular}{|c|c|c|}
\hline 1970 a 1979 & 1980 a 1989 & 1990 a 1999 \\
\hline & & ALECANDDAE BALBO (CONU, HAB) = 20/08/1993 \\
\hline & & AMÉRICAS (RESIDENCIAL DAS) $=14 / 10 / 1997$ \\
\hline & & ARUNDO LAGUNA (CONU. HAB.) $=22 / 11 / 1999$ \\
\hline & & AURORA VILLAGE (CONDOMMINUO) - 13/02/1998 \\
\hline & & BURITIS (CONDOMINIO) $=11 / 03 / 1994$ \\
\hline & & CARLOS DE LACERDA CHAVES (CONU. RES) = 22/11/1999 \\
\hline & & COUNA DOS SABIÁS (COND) $=22 / 12 / 1992$ \\
\hline & & COUNTRY VILAGE (CONO. RESIDÉNCIAL) = 07/12/1992 \\
\hline & ADÃO DO CARMO LEONEL (CONU. HAB.) • 19/04/1982 & D' ITALIA, VILA (CONDOMINIO) - 01/09/1996 \\
\hline & ADELINO SIMIONE $u$, $)=26 / 07 / 1984$ & DEL FIORL, VILA (CONDOMINIO) $=10 / 01 / 1993$ \\
\hline & ALVORADA (JD) = 10/04/19987 & DIVA TARLA DE CARVALHO (1D) $=15 / 10 / 1997$ \\
\hline & ANDORINHAS (PARQUE DAS) = 18/08/1980 & ESTACZ̃O PRIMAVERA (COND, RES.) - 10/02/1993 \\
\hline & ANTÒNIO MARINCECK (CONL, HAB) $• 28 / 04 / 1982$ & EUGEtNIO MENDES LOPES (JD) = 19/11/1999 \\
\hline & AVEUNO A. PALMA (CONU. HAB) - 25/05/1982 & FIGUEIRAS ILOT. PQ DAS) - 30/10/1996 \\
\hline & GANIDE IRANTES (PQ) $=20 / 03 / 1936$ & FiRENZEE (CONDOMINIO RESIOËNCIAL) $=0 / 02 / 1990$ \\
\hline & CAINDIDO PORTINAAI (LOT) $=02 / 07 / 1930$ & FLAMBOVANS (PQ DOS) $=14 / 05 / 1999$ \\
\hline & CIOADE UNIVERSITÁRIA $=15 / 04 / 1982$ & FLORESTAN FERNANDES $(I D$ ) $)=25 / 09 / 1997$ \\
\hline & DeLBoux (DD) $=26 / 05 / 1983$ & GENOVA (RESIDËnCIAL COND.) = 01/06/1993 \\
\hline & DOM BERNARDO JOSÉ MIEUE (CONU. HAB) = 13/03/2984 & HETTOR RIGON UD.) * 09/06/2995 \\
\hline AVELINO A PAUMA (PQ IND) $=14 / 05 / 1975$ & FLORIDA (RES) - 18/06/1982 & HELENA (DD) = 06/11/1997 \\
\hline ANitsiA (VL) $=16 / 06 / 1972$ & FORMOSO (UD) $=08 / 09 / 1982$ & JAMUL SENE CURY (CONL. HAB.) = 19/11/1999 \\
\hline BOA VISTA (RES) • 11/03/76 & GERALDO CORREIA DE CARVALHO (CONU HAB) - 39/09/1992 & JOLLO ROSS1 (jD) • 26/03/1996. \\
\hline CADACAAN (1D) $=14 / 12 / 1978$ & (TAPORÃ (ND) - 21/07/1987 & JOSE ROSERTO TÉO ND.) = 16/10/1998 \\
\hline CAR $\angle A D A ́ A D$ (J) $=18 / 09 / 1970$ & D. INTERLAGOS - 26/06/1990 & IOVINO CAMPOS (CONU. HAB) $=22 / 07 / 1992$ \\
\hline CASTELO (VL) = $15 / 02 / 1972$ & J0. SÃo JOSE (CONU. HAS) = 10/10/1985 & JULLANA (CONU, HAB, ID) - 11/10/1993 \\
\hline CASTELO BRANCO 2 (CONU. HAB. JD.) $14 / 09 / 1972$ & JOAQUIM PROCOPIO DE A.FERRAZ (CONU. HAB) = 10/08/1999 & LAGOS (LOT. PQ. DOS) = 14/09/1995 \\
\hline CASTELO BRANCO (CON. HAB. 10$)=17 / 08 / 1973$ & JOSE SAMPAIO IUNVIOR (CONL, MAB.) $=01 / 12 / 1985$ & MANOEL PERNA (CONU. HAB. JD.) = 20/03/1993 \\
\hline CITY RIBEIRÃO (LOT) & MARIA DA GRAGA (CONL HAB, 10.) = 16/08/1965 & MARIA CASAGRANDE LOPES (CONU. HAB) = 01/07/1994 \\
\hline EMiLAa (jo.) - 10/03/1973 & PALMARES (LOT) • 20/08/1980 & MONTEREY PARK (RESIDEENCIAL) • 21/08/1996 \\
\hline ESPERANGA IVLL $=22 / 11 / 1977$ & PLANALTO VERDE (WOT) - 28/04/1982 & OUVEIRAS (PARQUE DAS) = 16/09/1999 \\
\hline EUNICE $($ (D.) $=01 / 02 / 1972$ & QUINTINO FACC I ( & ORESTES LOPES DE CAMARGO (LOT) = 01/07/1994 \\
\hline FRANCISCO GUGUANO (JD.) 02/ 05/ 1975 (PARCIAL) & QUINTINO FACCI II (CONU. HAB.) $=14 / 11 / 1980$ & PAIVA 1 (UD.) = 19/11/1999 \\
\hline MORUMBi (UD) $=25 / 09 / 1975$ & RECREIO ITANHANGÁ $=24 / 05 / 1984$ & PALMEIRAS 1 (CONU. HAB. JD.) $=13 / 03 / 1990$ \\
\hline PANORAMA Sitios DE RECREIO = 18/05/1979 & RECGE IO RUMATTÁ = 20/10/1981 & PALMEIRAS 2 (CONU. HAB. JD.) $=25 / 10 / 1993$ \\
\hline PRES. DUTRA III (ND.) $\cdot 22 / 11 / 1977$ & ROVAL PARQUE * $16 / 10 / 1990$ & PINUS (PARQUE DOS) - 15/01/1999 \\
\hline PRIMAVERA (UD.) $=23 / 11 / 1970$ & SAN LEANDRO UD.) $=28 / 04 / 1982$ & PORTAL DO ALTO $=25 / 08 / 1999$ \\
\hline PRIMAVERA (RESID) $=23 / 11 / 1970$ & SOLAR BOA VISTA (CONL.) = 27/11/1980 & ROBERTO BENEDETT (CONL. HAE JD) $=31 / 07 / 19990$ \\
\hline RECREIO ANHANGUERA $* 16 / 12 / 1970$ & TANQUUNUHO (PQ IND.) - 27/04/1982 & SANTA ANGGELA ( RES) (ANTIGO VILLA FLORENGA) - 21/0B/96 \\
\hline AECREIO INTERNACIONAL = 25/06/1973 & VALENTINA DE FIGUEIREDO (CONU. HAB.) $=25 / 08 / 1983$ & SZ̃̄O FERNANDO (CONU. RES. JD. $=19 / 11 / 1999$ \\
\hline SANTA LUZLA (JD.) $=28 / 12 / 1979$ & VENEZZA (RESIDËNCLIAL) $=26 / 05 / 1939$ & VILA REAL (CONDOMINUO) $=26 / 12 / 1995$ \\
\hline SUMAREZZINHO = 14/01/1970 & VISTA ALËGRE (UD.) $* 29 / 12 / 1991$ & VPIRANGA (JD) (EMIR GARCIA) = 07/10/1998 \\
\hline
\end{tabular}

Tabela 8-Relação de parcelamentos aprovados em Ribeirão Preto, 1970 a 2011.

Fonte: Secretaria de Planejamento e Gestão Pública de Ribeirão Preto. 
Relação de Parcelamentos aprovados em Ribeirão Preto - 1970 a 2011

\begin{tabular}{|c|c|c|}
\hline 2000 a 2009 & & 2010 e 2011 \\
\hline ANTOÓNIO PALOCI (UD.) $=18 / 12 / 2004$ & & \\
\hline ARARA AZUL (VALE DAS ARARAS) (CONDOMINIO) $=04 / 10 / 2004$ & MARIO FAIVA ARANTES $($ UD $)=30 / 06 / 2000$ & \\
\hline ARARA VERDE (VALE DAS ARARAS) (CONDOMINIO) = 04/10/2004 & MILANO (CONDDOMiNi O RESIDENCIAL) = 19/08/2004 & \\
\hline ARARA VERMELHA (VALE DAS ARARAS) (CONDOMINIO) $=04 / 10 / 2004$ & MIRANTE ROVAL PARK (CONDOMINIO) $=21 / 08 / 2003$ & \\
\hline AROEIRA (COND) - 29/03/2000 & MONTE CARLO (J0.) - 23/09/2004 & \\
\hline ASPEN (CONDOMINIO) $=21 / 29 / 2004$ & MORRO DO $\mathrm{IDE}=20 / 02 / 2003$ & \\
\hline BOSQUE DOS JURITIS * 08/08/2002 & NORIVAL CORREA DE LACERDA (NÜCLEO HABITACIONAL) • 02/10/2003 & \\
\hline BOSQUE DOS JURITIS || = 19/11/2004 & NOVA ALUANGA (UD): $=31 / 05 / 2000$ & \\
\hline BOTÁNICO (1D.) - 24/01/2002 & NOVA ALAANCA SUL $=23 / 11 / 2004$ & \\
\hline BRANCA SALLES UD. DONA) $\cdot 24 / 01 / 2003$ & NOVA CITY (ND.) $=28 / 12 / 2004$ & \\
\hline CAIMBE (CONDOMINIO) $-28 / 11 / 2002$ & OURO BRANUCO (UD) $=03 / 06 / 2002$ & \\
\hline CAMPOS DE JORDÃO (CONDOMINIO) = 05/11/2002 & OURO VERDE (RESIOEENCIAL) $=14 / 11 / 2001$ & \\
\hline CAPMEL CONDO PARK (CONDOMINIO) • 05/11/2004 & PAINEIRAS ICONDOMINIÓ RESI DẼNCIAL) $=26 / 11 / 2002$ & \\
\hline CASAS D'ITALIA - CITÁ DI POSITANO (CONDOMINIO) - 13/09/2001 & PEDRA ERANCA UD, $=23 / 11 / 2004$ & \\
\hline CENTRAL PARK (JO) $=08 / 10 / 2001$ & PORTAL DOS PINHEIROS RESIDÉNCIAL (CONDOMINIO) = 16/09/2000 & \\
\hline CIDADE DA CRIANCA (RESIDÉNCIAL) $=13 / 09 / 2001$ & PORTO SEGURO (UD.J $=19 / 04 / 2002$ & \\
\hline COPACABANA (CONDOMINIO RESIDÉNCIAL) * 15/08/2301 & RAIOS DE SOL (CONOOMINIO) $\cdot 29 / 12 / 2004$ & \\
\hline DISTRITO EMPRESARIAL (1 ETAPA) $=16 / 04 / 2002$ & RECANTO DAS FLORES $=07 / 12 / 2004$ & \\
\hline DISTRITO EMPRESARIAL (2 ETAPA) $=28 / 09 / 2004$ & RETIRO DO BONFIM (CL RES) (COND) $=06 / 02 / 2004$ & \\
\hline GENESIO MASSARO (ID) $=14 / 02 / 2005$ & ROMANA (CONDOMINIO VILA) $=22 / 12 / 2004$ & \\
\hline GREENVILE (RESIDENCIAL) $=30 / 11 / 2004$ & RUBENS CIONE UD, DRY, $=30 / 12 / 2004$ & \\
\hline GUAPORE I (RESIDENNCIAL) $=05 / 09 / 2003$ & SABIÁS (PQ DOS) = 05/08/2003 & \\
\hline GUAPORE II (RESIDENCIAL) $=04 / 09 / 2003$ & SAPU FRANCISCO (CONDOMINIO VILLGE) - 20/09/2002 & \\
\hline GUEDES E TONANI (RESIDËNCIAL) $=12 / 03 / 2001$ & SAN REMO I (RESIDÉNCIALL LARDIM) $=30 / 07 / 2003$ & \\
\hline HERCULANO FERNANDES (UD.)=02/0E/2000 & SAN REMO II (RESIDÉNCIAL LARDIM) - 12/08/2002 & \\
\hline IPANEMA (CONDOMINIO RESIDENCIAL E COMERCIAL) = 15/08/2001 & SANTA ANGELA (JD) = 06/11/2003 & AGRA RIB PAETO (Loteamento) 18/11/2010 \\
\hline IPE AMARELO (COND, RESIDÉNCIAL) = 15/08/2001 & SANTA MOONICA (RESIDËNCIAL) $=12 / 06 / 2003$ & CRUZEIRO DO SUL (Condominio) 15/12/2010 \\
\hline IP R ROXO /COND. RESIDÉNCLAL) = 02/08/2002 & SIIVIO PASSALAQUA ICONI. HAB. JO) = 23/08/2000 & EVIDERice (Condominio) 14/10/2010 \\
\hline LATOEÁ (CONDOMMINIO RESIDÉNCIAL) = 08/09/2000 & ST. GERARD (LOTEAMENTO JD) $=02 / 10 / 2002$ & OLHOS D'ÁGUA (Loteamento) 29/10/2010 \\
\hline JAVARI (UD.) $=07 / 0 \mathrm{O} / 2000$ & STA. GENEBRA (UD.) = 13/03/2002 & PRACAS Do SUL (Condominio) 19/10/2010 \\
\hline IEQUITIBÁ (CONDOMINIO RESIDÉNCIAL) $=06 / 05 / 2003$ & TORINO (CONDOMINIO) $=17 / 08 / 2004$ & QUINTA DO GOUF (CONdominio) $26 / 07 / 2010$ \\
\hline JOÃO JOSÉ SAID SOERINHO I (CONL. HAQ) - 23/12/2003 & VERONA (CONDOMINIO) $-17 / 08 / 2004$ & RECANTO \\
\hline JOÃO JOSÉ SAID SOBRINHO it (CONU. HAB) $• 23 / 12 / 2003$ & VILA VITORIA (RESIDENGIAL) *31/10/2001 & SANTA LUISA (Loteamento) 26/01/2010 \\
\hline JOSE FIGUEIRA (UD) = 12/03/2001 & VILA DE BUENOS AIRES (CONO. RESIDÉNCIAL) $=22 / 07 / 2004$ & SANTA MARTA (Loteamento) 30/08/2011 \\
\hline LEBLON (CONDOMINIO) - 15/08/2001 & VILLA FLORENGA I (ANTIGO SAVTTA ÂNGELA) (COND) = 03/07/2002 & SiEvia (Condominio) o8 /07/2010 \\
\hline LEO GOMES DE MORAES * 21/03/2003 & VILLA FLORENCA II (ANTIGO SALVTA ANGELA) (CONO.) - 03/07/2002 & TERRAS DE SIENA (Loteamento) $17 / 11 / 2011$ \\
\hline MAGNOULAS ICONDOMINIO RESIDENCIAL) $=15 / 02 / 2002$ & VILLGE JD, DOS GERÃNIOS (RESID. VILLA DOS IARDINS) = 21/10/2004 & VIUCO CANTAREUU (Loteamento) 30/06/2011 \\
\hline MANACÁS, DOS (CONDOMINIO RESIDÉNCIAL) $=19 / 03 / 2003$ & VILAGE ID, DOS HIBISCOS (RESID, VILA DOS JAROINS) = 21/10/2004 & VISTA BELA (Loteamento) 03/02/2011 \\
\hline MARIA DE LOURDES (JD.) $=23 / 12 / 2003$ & VILLAGE MONET (CONDOMINIO) * 18/09/2003 & VIVENDAS DO SUL (Condominio) $15 / 12 / 2010$ \\
\hline
\end{tabular}


sagens e desequilíbrios econômicos, sociais, culturais, territoriais", o que caracteriza o crescimento das cidades brasileiras, agravando a concentração de renda, aumentando a pobreza urbana e diferenciando as formas de consumo, de habitação e de acesso aos sistemas públicos, resultando, consequentemente, na construção de cidades corporativas.

Conforme a figura 21, é possível analisar a expansão da malha urbana de Ribeirão Preto, levando em consideração o crescimento da cidade, através de um processo de conexão entre bairros dispersos, preenchendo os vazios entre eles, bem como os sentidos para onde a cidade se expandiu, levando-se em consideração a localização com relação ao centro, as facilidades e conveniências dos setores e a distribuição de renda na cidade, que concentrou a parcela mais rica na região sul, e a reprodução do setor norte, através de conjuntos habitacionais e bairros populares.

A tabela 8 lista os loteamentos e empreendimentos aprovados nas últimas décadas, através dos quais se deu a reprodução do espaço urbano de Ribeirão Preto. Nota-se que até os anos 1920, a malha se encontrava praticamente pulverizada pela municipalidade, com bairros afastados entre si e do centro da cidade. De 1920 ao início dos anos 1970, o espaço entre tais bairros foi sendo preenchido, principalmente na área norte da cidade. A partir dos anos 1980, os espaços vazios localizados dentro do anel viário foram preenchidos com mais intensidade (principalmente na região norte, que teve um crescimento contínuo até o final desse período) e uma expansão no sentido sul foi verificada, extrapolando o anel viário e revelando novos processos de reprodução urbana, inclusive a adoção de condomínios horizontais fechados para classes mais elevadas. A malha ribeirão-pretana revela tal segregação socioeconômica ao apontar uma concentração da população de renda média alta na região sul, em contraponto a bairros mais populares e de menor renda, no setor norte. Analisando a figura 21, em conjunto com a tabela 8 e a figura 22, nota-se que os conjuntos habitacionais foram implantados no setor norte e tiveram uma desaceleração a partir dos anos 1990, em contrapartida à proliferação de empreendimentos no mesmo período no setor sul, coincidindo também com os primeiros condomínios residenciais horizontais.

A década de 2000 revela o período com maior número de lançamentos imobiliários: 77 empreendimentos lançados e registrados (11 a menos do que o registrado durante a década de 1950), porém com 


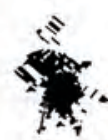

1940-1949

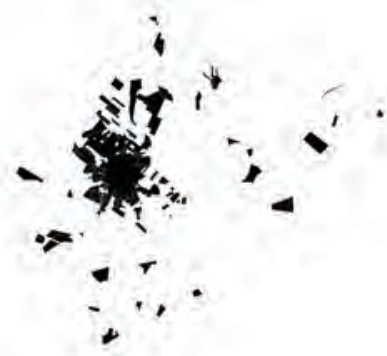

1980-1989

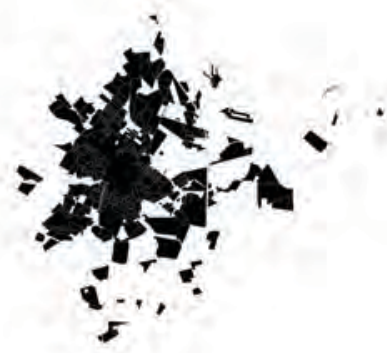

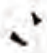

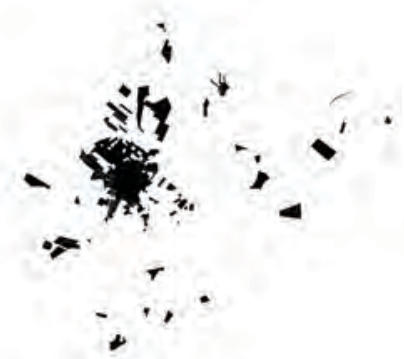

$1950-1959$

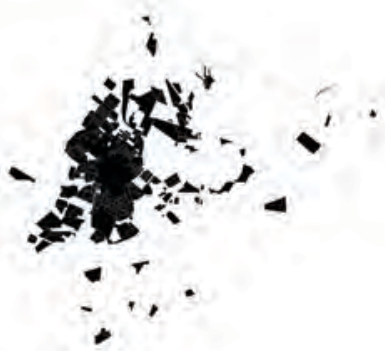

1990-1999

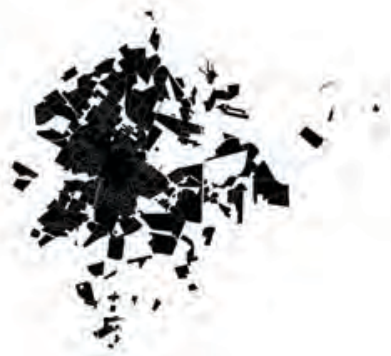

$\therefore$

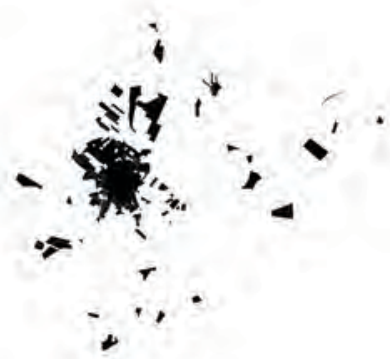

1960-1969

1970-1979
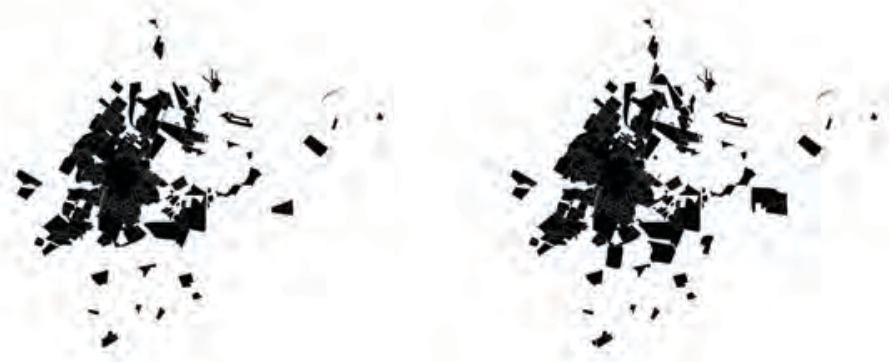

2000-2009

2010-2013
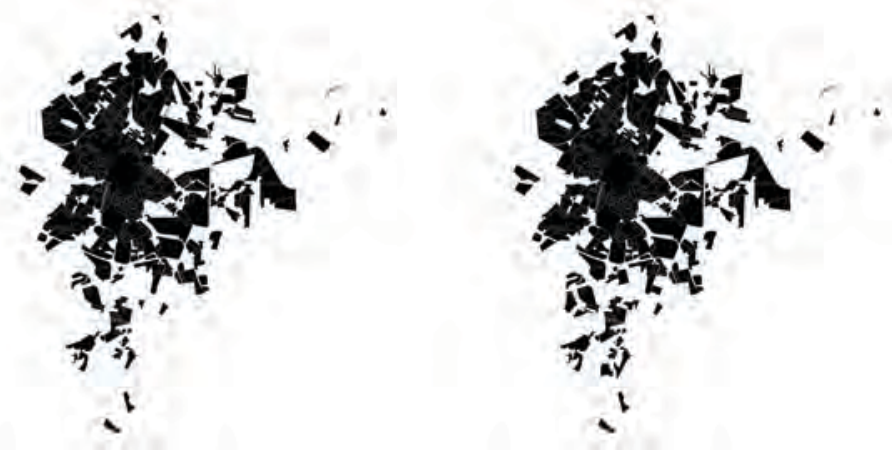

Figura 21 - Diagrama de evolução da malha urbana de Ribeirão Preto de 1900 a 2013.

Elaborado pelo autor com base em dados fornecidos pela Prefeitura Municipal de Ribeirão Preto. 

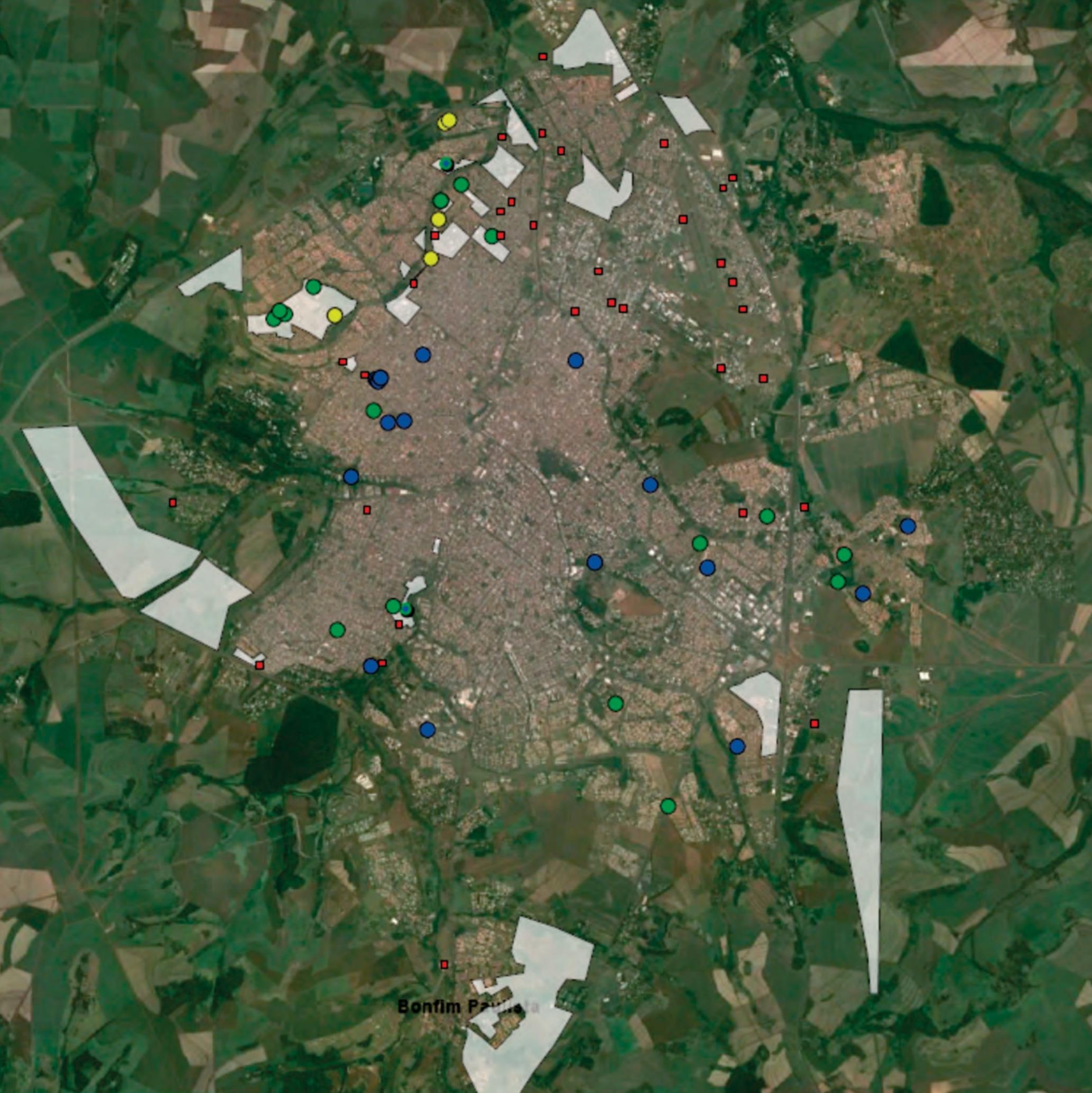
Figura 22 - Localização dos empreendimentos do Minha Casa Minha Vida em Ribeirão Preto 2012.

Os pontos amarelos, verdes, azuis e verdes escuros representam, respectivamente, os empreendimentos de faixas 1, 2 e 2-3 contratados até dez/2012. Os pontos vermelhos indicam núcleos de favelas e as áreas cinzas, as Áreas Especiais de Interesse Social do município.

Fonte: Ministério das Cidades e Caixa Econômica Federal. Dados cedidos pelo projeto "Produção do Programa MCMV na região central do estado de São Paulo: inserção urbana e avaliação arquitetônica, construtiva e tecnológica", coordenado pelos professores Dra. Lucia Shimbo, Dr. João Marcos de Almeida Lopes e Dra. Kelen Dornelles vinculado ao projeto Rede Minha Casa Minha Vida, 2012. Instituição responsável: Instituto de Arquitetura e Urbanismo de São Carlos, Universidade de São Paulo. 2013.

148. Os loteamentos fechados surgiram como uma nova mercadoria, travestindo os lotes com uma nova roupagem, relacionando a propriedade do solo com valores subjetivos, ideológicos e questionáveis, como segurança, tranquilidade, bem-estar, qualidade de vida e um novo modo de morar "moderno".

149. Também conhecido como vinhoto ou restilo, é o resíduo pastoso e malcheiroso que sobra após a destilação fracionada do caldo de cana-de-açúcar comumente empregado na lavoura como substituto de fertilizantes. uma maior reprodução de condomínios (dentre eles, os residenciais Torino, Milano e Verona, da construtora Stéfani Nogueira) e pouco menos de cinco conjuntos habitacionais em uma década. A produção habitacional só voltou a ser recuperada nos anos 2010, através dos empreendimentos do Minha Casa Minha Vida, implantados predominantemente na área norte, zona de maior concentração de população de baixa renda. De 14 empreendimentos urbanos lançados entre os anos 2010 e 2012, 6 são condomínios residenciais.

O processo de urbanização analisado na cidade de Ribeirão Preto possui evidências semelhantes às encontradas nas grandes metrópoles brasileiras, como a relação de um centro que polariza atividades e que começa a se estagnar, além da alta taxa de verticalização que se inicia no centro e da formação de "periferias privilegiadas"desde a ocupação da zona sul até a produção de condomínios fechados afastados do centro. A expansão sentido distrito de Bonfim Paulista indica tal modalidade de reprodução, fortemente mercantil e de fragmentação ${ }^{148}$, crescente tanto nas cidades de grande escala como nas menores. O percurso entre Bonfim Paulista e Ribeirão Preto, de 2009 a 2012, mudou drasticamente com os canaviais e o cheiro de vinhaça ${ }^{149}$, sendo substituídos pelos gramados verdes e portarias de condomínios horizontais fechados. BRAJAS (2006) afirma que a produção de condomínios possui aspectos relevantes em seu processo de produção, a exemplo do modo como os promotores vendem as propriedades antes da construção - a famosa pré-venda, a partir da qual se capitalizam recursos e se financia o empreendimento, acelerando o processo de acumulação.

No que tange à reprodução do urbano, a economia política de desenvolvimento urbano transformou a cidade em uma verdadeira vitrine de empreendimentos dotados de características específicas que o valorizam (como qualidade de vida urbana, segurança, distâncias de pontos visados pelos consumidores, dentre outros valores imateriais), criando nichos de mercado pautados em escolhas de estilos de vida urbano, hábitos de consumo e normas culturais, através do trabalho imaterial, gerando necessidades que serão suplantadas ao se adquirir o produto, seja ele um lote, um apartamento ou uma casa em condomínio horizontal fechado. Segurança, medo dos outros, preferências sociais, preconceitos, estigmas sociais, distâncias, deslocamentos e diversas outras questões (muitas delas geradas pela própria produção desigual do espaço) são incorporadas à promoção e negociação de empre- 
endimentos do mercado imobiliário, valorizando em demasiado algumas áreas em detrimento de outras, gerando especulações e "acumulação por despossessão"150.

Deste modo, a produção urbana torna o mercado imobiliário um negócio bastante rentável, a partir do qual a especulação permite gerar lucros suntuosos. Assim, vale-se da importância do papel regulamentador do Estado, para se evitar e/ou controlar para que as cidades evitem se expandir rapidamente e sem medidas, não otimizando redes de infraestrutura, tornando-se impraticáveis e insustentáveis.

Em contraponto, se a aplicação dos investimentos estabeleceu foco em determinadas áreas da cidade, acabou gerando desvantagens em outras. Foi o caso das áreas mais periféricas de Ribeirão Preto, com maiores dificuldades em relação ao acesso a serviços, como os bairros localizados nos subsetores Leste da cidade, para além da rodovia Anhanguera, e nos subsetores Norte, onde se concentram as populações de média e baixa renda da cidade e onde assentamentos precários são mais frequentes, conforme visto nas figuras 13 e 22 . Novas formas de vivência e organização urbanas acabam sendo reveladas, além de uma grave sobreposição do privado sobre o público e do individual sobre o coletivo, o que contribui para a segregação sócioterritorial na cidade.

Em Sertãozinho também é possível encontrar eixos de expansão articulados com a reprodução de espaços de segregação socioeconômica. Considerada uma das principais cidades brasileiras especializadas na produção canavieira, possui enorme participação na economia e produção do complexo agroindustrial canavieiro da região, dada sua transformação industrial, e na produção de equipamentos voltados à produção canavieira, abastecendo para além do setor local e exportando para outras regiões brasileiras e para o exterior.

A forte concentração fundiária e a expansão e superioridade do latifúndio sobre o minifúndio foram fatores importantíssimos para o desenvolvimento e crescimento da agroindústria na cidade. A intervenção estatal com o Pró-Álcool acelerou a aglutinação de propriedades agrícolas próximas às usinas, expandindo a produção canavieira, da qual boa parte é utilizada pelas próprias usinas, "promovendo forte concentração fundiária e de renda"151. O setor industrial, instalado no munícipio ao longo das rodovias SP-322 e SP-333, principais vias de acesso da cidade, concentrando distritos e instalações industriais ao sul, atraiu, assim como os canaviais, grande contingente populacional em busca
150. HARVEY (2011) define assim os processos de expulsão de populações de suas propriedades por meios legais (sancionados pelo Estado) ou ilegais, reincorporando forçosamente tais populações ao mercado comercial pela monetização e tributação. A exemplo da mecanização do campo, a especulação imobiliária e a valorização de áreas urbanas e aumento de IPTU.

151. Ibid., p. 306. 
de empregos e melhores condições de vida. Assim como as cidades da região, Sertãozinho sofreu um boom populacional que praticamente triplicou sua população após os anos 1970, passando de 22 mil habitantes para 73 mil no início dos anos $1990^{152}$. Atualmente, possui cerca de 100 mil habitantes ${ }^{153}$.

Conforme a figura 23 permite visualizar, até fins da década de 1950 a malha urbana de Sertãozinho correspondia à área que hoje é considerada a região central da cidade, compreendendo um polígono delimitado a norte pela linha férrea, e a sul pelo terminal rodoviário interurbano. A partir dos anos 1960, a cidade se expandiu por quatro eixos principais. O primeiro trata-se de um eixo a sul e a sudoeste e ao longo das principais rodovias que ligam a cidade às cidades vizinhas, caracterizado pela reprodução de loteamentos industriais.

Um segundo eixo é localizado a sudeste, entre a via de acesso Octávio Verri e a SP-333. O crescimento sudeste se deu através de recentes loteamentos residenciais e condomínios fechados ao norte da SP-333, e de loteamentos industriais ao sul da rodovia. É nessa região que se localizam o monumento do Cristo Redentor, que rapidamente valorizou o preço dos lotes dos empreendimentos recém-lançados naquela área, e o pórtico de entrada da cidade, que se utiliza de um desenho e uma linguagem que muito se aproximam do neoclássico corporativo que se reproduz em portarias de condomínios horizontais fechados.

Outro eixo de expansão é encontrado na área norte da cidade, a partir dos anos 1970, decorrente da reprodução de conjuntos habitacionais, indicado pela extensão da Avenida Aléssio Mazzer, compreendendo os bairros Jardim Santa Marta, Jardim Santa Rosa, Santa Clara e Engenho. Constitui uma reprodução de padrões de classe média e mais humildes, compreendendo também áreas destinadas a conjuntos habitacionais e aos empreendimentos do programa do governo federal Minha Casa Minha Vida, que contempla as faixas 1 e 2 (famílias com faixas de renda menores) do programa. Ainda ao norte da cidade, há uma expansão no sentido Alvorada, um dos bairros que reúnem a população de mais baixa renda. Com exceção do distrito de Cruz das Posses, nos anos 1990, nota-se que a cidade não expandiu sua malha urbana no sentido centro-nordeste, de modo que praticamente não se avançou para além do bairro Jardim Alvorada desde os anos 1960.

Já ao sul da cidade, próximo aos bairros Recreio dos 


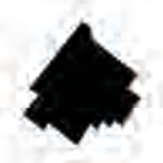

$1960-1970$

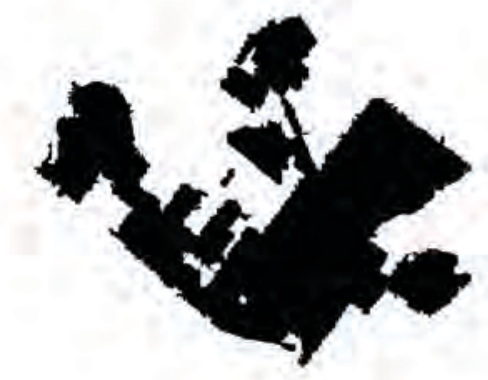

Figura 23 - Diagrama de evolução da malha urbana de Sertãozinho de 1950 a 2005.

Dados do Diagnóstico do Plano Diretor. Fonte: PLHIS Sertãozinho, 2011.

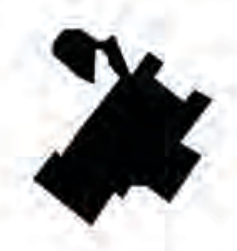

1970-1990

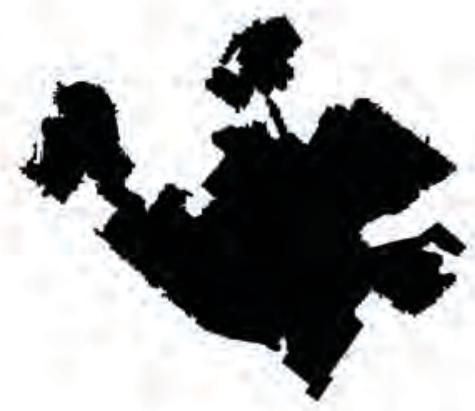

1960-2005

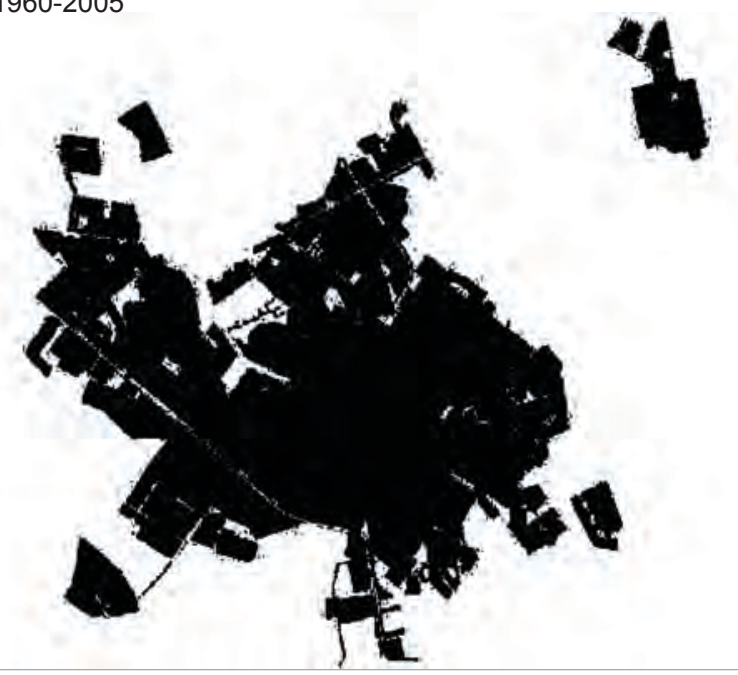


des condomínios horizontais fechados, como o Burle Marx e o Green Park, localizados em área mais elitizada da cidade e com facilidade de acesso à estrada que liga Sertãozinho com Ribeirão Preto. Aliás, a reprodução de loteamentos fechados tem sido uma alternativa na ocupação de glebas vazias no interior da cidade, como no caso dos condomínios Quinta da Boa Sorte e Bella La Vita, localizados na Avenida Egisto Sichieri (principal via que liga o centro aos bairros mais afastados a oeste da cidade), empreendimentos lançados através de grandes empresas imobiliárias e urbanizadoras da cidade. A reprodução de condomínios nessa área sinaliza processos de especulação e que a parcela da população sertanezina com maior renda ocupa as áreas mais próximas do centro (dado o alto poder aquisitivo necessário para se comprar imóveis em tais áreas, vide sua localização). É possível destacar também que, dada a proximidade com Ribeirão Preto, muitos sertanezinos com maior renda acabam residindo em bairros de classe média alta da cidade vizinha, o que configura um processo socioeconômico intermunicipal .

O último eixo se localiza a oeste da mancha urbana, paralelamente à rodovia SP-322, que liga a cidade a Jaboticabal. Tal região da cidade teve como principal objeto de reprodução urbana os loteamentos residenciais populares e conjuntos habitacionais, que foram se consolidando ao longo da Avenida Nossa Senhora Aparecida, paralelamente à rodovia. A expansão nesse eixo continuou nas décadas seguintes, e atualmente a área se configura enquanto segunda centralidade na cidade, tendo tal avenida como principal eixo estruturante da expansão. Recentemente, vários empreendimentos foram lançados na área, culminando com a implantação do primeiro shopping center da cidade, cujas obras estão localizadas no extremo noroeste da malha urbana. Este eixo ganhou destaque nos anos 2000, por conta da criação do parque ecológico municipal, localizado a sul da rodovia. Boa parcela dessas terras, localizadas a oeste da malha urbana do município, é de propriedade da BEABISA - Pecuária, Agricultura e Empreendimentos, grande conglomerado agropecuário atuante na região, controlado pela família Biagi Becker.

Com sede em Ribeirão Preto, o grupo apresenta uma trajetória significativa no setor do agronegócio. Atualmente possui atividade agropecuária distribuída em fazendas nas cidades de Pontal, Rio da Mata e Morro Agudo - as três em São Paulo -, e em Selvíria, MS. O grupo também contempla a produção pecuária, produzindo bovinos da raça 
Nelore, investindo no melhoramento genético, através dos principais criatórios da raça, e passando a integrar, em 1999, o Programa de Melhoramento Genético da Raça Nelore - Nelore Brasil -, da Associação Nacional de Criadores e Pesquisadores (ANCP). Com relação a equinos, trabalha com a raça Mangalarga, visando à produção de cavalos para competições, lazer, utilitários e projetos sociais de equoterapia, assim como animais rústicos para lidar com a produção de gado. Para além do ramo da pecuária, a empresa possui efetiva produção agrícola, pautada no cultivo da cana-de-açúcar, tendo participação acionária na BioSev e parceria em usinas do grupo LDC SEV Bioenergia S/A. O grupo possui atuação no mercado agrícola, com foco na pecuária, avicultura e equinos. Segundo dados da Biosev, as propriedades do grupo localizadas na região de Ribeirão Preto fornecem açúcar e etanol para a multinacional. Em 1999, iniciou uma nova divisão voltada para a atividade imobiliária, sobretudo para o parcelamento do solo em suas próprias propriedades, que vinham sendo faceadas pela malha urbana de cidades em expansão. Deste modo, reproduziu e ampliou o espaço urbano residencial e de serviços da cidade de Sertãozinho, através de loteamentos como o Jardim Boa Vista (400 lotes); em seguida pelo Jardim Campo Belo (500 lotes), Jardim Porto Seguro (450 lotes) e Jardim Campo Alegre (500). Segundo a empresa, todos esses empreendimentos tiveram seus lotes comercializados em um curto espaço de tempo, o que não foi diferente dos loteamentos industriais localizados próximos à rodovia SP-322, como o CINEP I, em 2004, composto por 100 lotes com cerca de $1000 \mathrm{~m}^{2}$; e os 100 lotes do CINEP II, de 2006. Até o presente momento desta pesquisa, encontra-se em fase de projeto 0 CINEP III, também de caráter industrial.

Em 2012, a empresa, em conjunto com outras empresas voltadas para empreendimentos imobiliários - de projetos, loteadoras e imobiliárias -, lançou o empreendimento denominado Jardim Nova Europa (ver figuras 24 e 25), distante cerca de 4 km do centro da cidade, localizado em uma área de expansão urbana, de acordo com o plano diretor, e que contempla lotes habitacionais populares, mistos com comércio e/ou serviços, e também lotes industriais, dada sua proximidade a estruturas importantes para a produção industrial - no caso, a rodovia Armando Salles de Oliveira e loteamentos industriais vizinhos. A terra, propriedade da antiga Usina Santa Elisa (posteriormente Santelisa Vale, e atualmente BioSev), tratava-se de um extenso canavial, cuja produção era destinada à própria usina, que processava a matéria-prima 


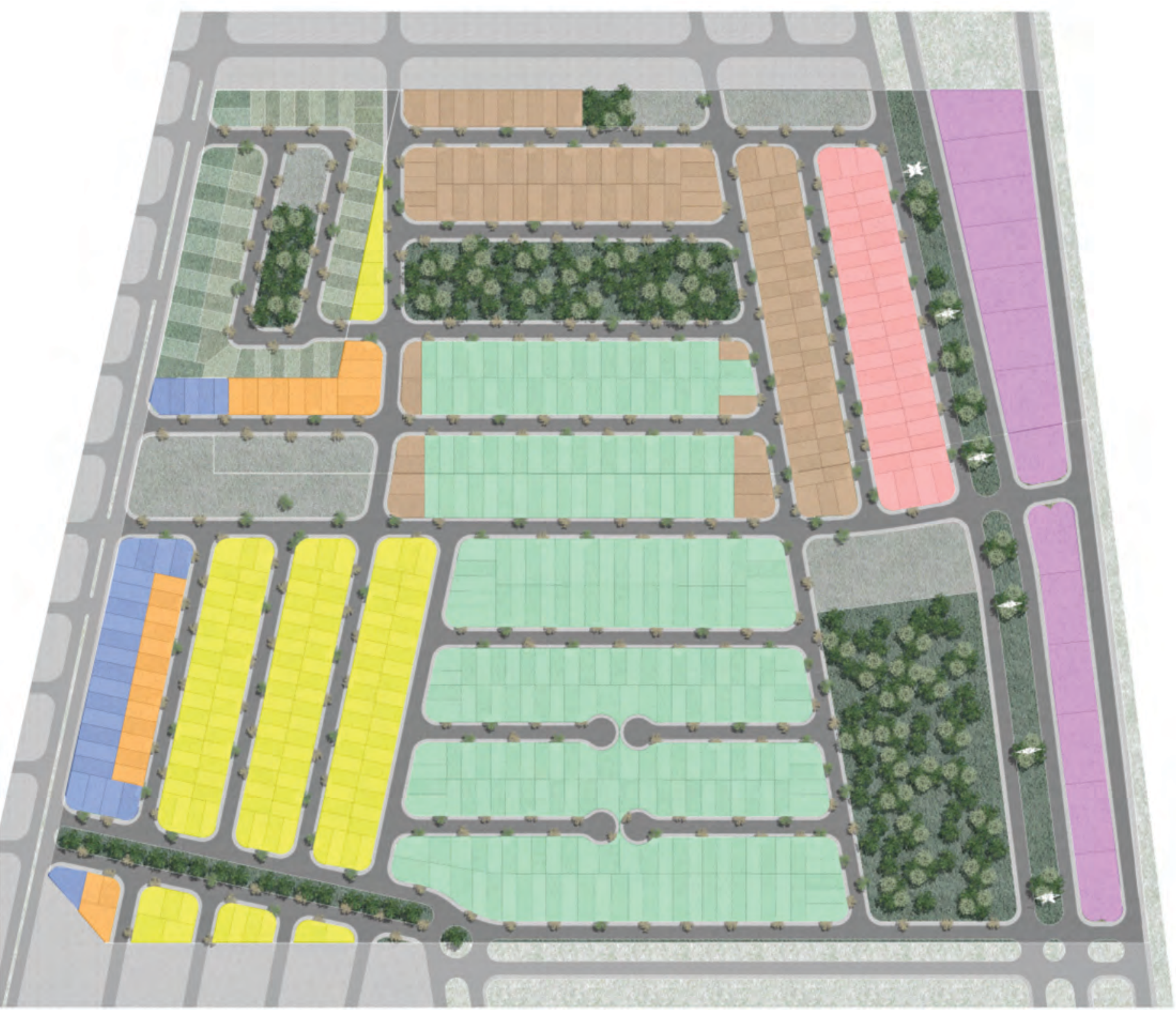

Figura 25 - Mapa de distribuição e variação dos preços dos lotes do empreendimento Jardim Nova Europa-Sertãozinho, SP.

0 preço dos lotes está relacionado à localização dos mesmos dispostos na área do empreendimento e à proximidade de equipamentos públicos e avenidas já existentes. Os lotes com maior preço por metro quadrado são os azuis ( $\left.R \$ 350,00 / \mathrm{m}^{2}\right)$, seguidos pelos de cor laranja, amarela, marrom, verde, rosa e roxo $\left(R \$ 220 / \mathrm{m}^{2}\right)$. Elaborado a partir de tabelas de preços fornecidas em uma imobiliária local. 
154. Os lotes do empreendimento possuem cerca de 200 a $300 \mathrm{~m}^{2}$, exceto os lotes industriais, que têm maior área, variando de 1300 a $1900 \mathrm{~m}^{2}$. Sendo assim, o empreendimento comtempla lotes que custam de $\mathrm{R} \$ 46$ mil a $\mathrm{R} \$ 105$ mil. É importante ressaltar que isto não ocorreu apenas neste empreendimento específico. Ao fazer uma busca por terrenos à venda em toda a cidade de Sertãozinho, nota-se que o preço das propriedades oscila nesta faixa. Em alguns casos, em imóveis localizados na área central, residências chegam ao valor de mais de um milhão de reais. para a produção de seus derivados. Agleba possui 38,07 hectares.

A planta de venda do Jardim Nova Europa permite analisar como o preço é atribuído à área quadrada dos lotes, tendo em vista a variação decorrente da localização, a variação de metragem e o destino do uso da terra, agora não mais agrícola. Os lotes que estão mais próximos da avenida do bairro vizinho e aqueles que estão próximos aos limites dos bairros vizinhos já consolidados têm preços maiores e que se destacam dos preços dos lotes mais internos à área do loteamento e dos lotes industriais, próximos à rodovia. Pode-se observar que, dada a alteração do valor de uso e em virtude da localização da mercadoria terra seu valor de troca é elevado, expressando-se, assim, em seu preço, que varia de $\mathrm{R} \$ 220,00$ a $\mathrm{R} \$ 350,00$ o metro quadrado ${ }^{154}$.

A segunda fase do empreendimento - correspondente aos lotes que não estão preenchidos com cor, localizados no canto superior esquerdo da figura 19 - não foi colocada à venda até a finalização deste documento, o que indica um possível caráter especulativo da operação, tendo em vista, ainda, a comercialização de outros 56 lotes a preços superiores aos vendidos até então, buscando valorizá-los através do desenvolvimento das áreas adjacentes.

Tais terras da Beabisa, conforme visto, estão localizadas em um ponto do município de Sertãozinho em que surge a possibilidade de alteração do uso do solo, ou, em outras palavras, onde se abre uma nova oportunidade de negócio: a reprodução urbana. Reprodução porque apenas reproduz o caráter urbano das mediações, bem como processos especulativos e de segregação socioterritorial. Muitas vezes, essa expansão tem como foco alterar o mercado imobiliário em determinada área da cidade, através de equipamentos urbanos que acabam gerando um aumento no valor da terra, como a construção de um pórtico, de uma réplica de ícone religioso (e turístico), ou de um shopping. O Sertãozinho Shopping é um empreendimento localizado nas terras da Beabisa, fruto de parcerias com construtoras da cidade e com o setor público, que viabilizou a construção. A construção do equipamento faz parte de um masterplan que compreende a totalidade das áreas de propriedade da Beabisa em Sertãozinho, destinado ao parcelamento do solo para uso urbano, elaborado por arquitetos da empresa. De acordo com informações da própria empresa, os projetos são "diversificados", contemplando residências unifamiliares, condomínios verticais e condomínios horizontais fechados. Que a cidade se transformou em negócio e que a habitação é um ótimo produto a ser comercializado, disso 
não há dúvidas. A própria empresa, em sua página na internet, afirma que seu foco está no mercado e que seus produtos buscam realizar desejos de "elevação de qualidade de vida da comunidade".

A produção de loteamentos revela o modo como a cidade se organiza, pautado em um zoneamento previsto em plano diretor, completamente influenciado por interesses privados, sobretudo dos proprietários de terras localizados nas áreas de expansão urbana, o que contribui fortemente com o processo de segregação sócio-territorial. De um lado, a implantação de condomínios fechados ou shopping centers em pontos específicos da franja urbana pressupõem um padrão específico de ocupação do território (como a zona sul ribeirão-pretana), atraindo populações de maior poder aquisitivo e, consequentemente, valorizando terrenos adjacentes em um processo especulativo, até o ponto de se tornar, para o proprietário da terra, um negócio tão lucrativo ou mais que a própria produção agrícola. Do outro, a necessidade de alojamento de populações de classes mais baixas tende a comprometer o processo de valorização, pois, do ponto de vista do mercado, são em empreendimentos voltados para programas de habitação social onde se localizam pontos geradores de violência e de outros atributos negativos que comprometem a imagem dos empreendimentos comercializados para as classes média, média alta e de alto padrão (a exemplo do Jardim Alvorada, em Sertãozinho). Por outro lado, constituem em grandes filões para a obtenção de recursos estatais através de programas de habitação social (como o Minha Casa Minha Vida nas zonas norte tanto de Ribeirão Preto quanto de Sertãozinho).

Retomando o ponto de vista da rede urbana, a produção separada por classe dentro das cidades também se torna perceptível quando se amplia o campo de análise para a região. Parte da população que trabalha em Ribeirão Preto não necessariamente reside na cidade, mas em cidades vizinhas que estão articuladas às dinâmicas de Ribeirão Preto, tais como fornecimento de um mercado de trabalho crescente em um setor e mercado imobiliário aquecido e focado em outro nicho populacional. Isso acaba gerando uma produção de loteamentos habitacionais não para a população dessas cidades vizinhas, mas para a população formada por trabalhadores dos setores de serviços, que geram o movimento pendular, muitas vezes causado pela oferta de lotes ou residências de preços mais baratos do que os encontrados nas cidades onde trabalham. De tal ponto de vista, a produção de habitação em outras cidades passou a estar articulada às dinâmicas de Ribeirão 


\section{ALENCAR; LANDIM, 2003.}

\section{LEFEBVRE, 1970.}

157. Cabe ao urbanismo mascarar a articulação entre ambos os círculos, impedindo que o pensamento se torne reflexão sobre o possível, sobre o futuro, aprisionando a reflexão em uma situação de enfrentamento entre reflexão crítica, ideologia reformista e a contestação "esquerdista". A parte utópica dos projetos urbanísticos não perde interesse enquanto anúncio da problemática, ainda que sem explicitá-la. A promoção do urbano está relacionada ao mesmo à recusa do crescimento econômico tornando como fim em si, à orientação da produção para outros fins, à primazia do desenvolvimento qualitativo sobre o crescimento, à redução do Estado a uma função subordinada e à crítica radical do Estado e da política (LEFEBVRE, 1970, p.147).

158. LEFEBVRE, 1970, p. 148. O autor ainda cita a sociedade burocrática de consumo dirigido, na qual o urbanismo está inserido enquanto superestrutura, distinguindo-se a si mesmo e às práticas, relações sociais e da própria sociedade. Ao mesmo tempo, organiza um setor que aparentemente está livre e disponível à ação racional: 0 espaço habitável, dirigindo o consumo do espaço do habitat.

159. BOTELHO, 2007, in: REIS, 2007, p. 281.
Preto - como a necessidade de provimento de habitação para um mercado de trabalho crescente na cidade.

A produção do espaço urbano está intrinsecamente articulada com a dinâmica econômica e financeira, constituindo-se no conjunto de diferentes usos da terra justapostos, consequentes de ações de agentes concretos - proprietários dos meios de produção, proprietários fundiários, promotores imobiliários, Estado, grupos sociais excluídos ${ }^{155}$. Também está articulada à nova escala de reprodução do capital, marcada pela concentração, centralização e mundialização do capital. A crescente inserção do mercado imobiliário no mercado financeiro ajudou a contribuir para o aumento do poder dos empreendedores sobre o espaço urbano, além de intensificar o processo triádico lefebvriano de homogeneização, fragmentação e hierarquização do espaço.

Capitais financeiro e imobiliário se uniram, de modo que a estrutura e tecido urbanos passaram a ser afetados pelas variações e dinâmicas financeiras de pregões e bolsas de valores ${ }^{156}$. O mercado e urbanismo imobiliários consistem em um segundo setor da produção industrial voltada para o mercado de bens não duráveis (menos duráveis que os imóveis), absorvendo os choques nos casos de depressão e os capitais excedentes, iniciando com lucros fabulosos que logo se enterram: o capital se imobiliza no imobiliário. Na medida em que o círculo principal (da produção industrial) arrefece seu impulso, os capitais são investidos no segundo círculo - daí sua importância crescente -, até que a especulação fundiária se transforme na fonte principal de "formação de capital" da realização da mais-valia ${ }^{157}$. O urbanismo, portanto, se mostra como "um veículo de uma racionalidade limitada e tendenciosa da qual o espaço, ilusoriamente neutro e não-político, constitui o objeto (objetivo)"158.

No Brasil, os instrumentos de união entre capital financeiro e setor imobiliário surgiram através da lei 8.668/1993, e passaram a ser regulamentados pela Comissão de Valores Mobiliários - CVM. Articularam-se, assim, mercado financeiro e imobiliário, sem a intermediação bancária no financiamento da produção. Com a securitização, permitiu-se ampliar "as possibilidades de captação de recursos e acesso a financiamento aos 'originadores' desses créditos (as empresas que produzem os ativos a serem securitizados, como as incorporadoras, construtoras, etc.), dando acesso direto ao mercado de capitais, reduzindo, teoricamente, os custos e riscos da captação de recursos financeiros" ${ }^{159}$. A securitização permitiu também uma maior velocidade 
no giro do capital investido, possibilitando "a venda à vista dos direitos de longo prazo referentes aos imóveis securitizados".

Nesse período, os Fundos de Investimento Imobiliário (FIls) ganharam importância, com um capital financeirizado e em crescente mundialização, captando recursos para incorporação e construção de imóveis voltados para atividades empresariais, de locação comercial, para agroindústrias ou até mesmo para empreendimentos agropecuários. Os cotistas passaram a ser remunerados pela renda dos aluguéis dos imóveis em contratos de longo prazo e pela valorização dos imóveis - através de mudanças de infraestrutura na região, ou aumento das demandas. Os Flls tornam o investimento imobiliário acessível a pequenos e médios investidores, através do fracionamento da emissão de cotas, evitando trâmites de escrituras e certidões no setor imobiliário, dando-lhe maior mobilidade. Para quem toma os recursos finais, acaba havendo um aumento no número de emprestadores, diminuindo a dependência com relação a grandes investidores. As cotas podem ser negociadas em bolsas de valores também, explicitando o uso e ocupação de empreendimentos urbanos, e logo a produção de cidade, articulados a dinâmicas de mercados financeiros.

Entretanto, os projetos alvos dos Flls normalmente eram aqueles que visavam a oferecer a seus investidores um rendimento que estava acima das possibilidades oferecidas pelo mercado de habitação popular ou econômica, de modo que os principais empreendimentos acabavam se tornando shoppings, complexos de escritórios e edifícios de alto padrão. Ainda que sejam alvo de desconfianças em meio aos aplicadores, os Flls são comumente utilizados para a captação de recursos para projetos imobiliários ou securitização de imóveis existentes. Com esses novos instrumentos, amplia-se o poder de intervenção no espaço urbano das empresas do setor imobiliário, "garantindo recursos necessários tanto para a superação da barreira colocada pelos altos preços da terra urbana nas áreas mais valorizadas, quanto para a aceleração do tempo de capital no setor da construção" ${ }^{160}$. Deste modo, atribuíram-se ao mercado imobiliário grandes potencialidades de formas de urbanização.

Tanto a dinamização de um mercado imobiliário quanto a atuação de construtoras, incorporadoras, imobiliárias e outros agentes traduzem reflexos da intensificação de demandas de um mercado globalizado, constituindo um ponto de destaque nas cidades, ao promover a implantação de loteamentos para atender a famílias de classe média, a 
161. Uma questão levantada, tendo em vista o papel de propriedade do campo industrializado é: o espaço público seria a característica fundamental para o pensamento $\mathrm{e}$ existência da cidade tal qual a conhecemos? A ausência de espaços públicos define o que não é cidade? Seriam então as cidades os verdadeiros locus de produção de espaços públicos em meio a uma grande região completamente particular, composta por latifúndios e reservas naturais?

162. Por localização subentende-se infraestrutura urbana disponível - realizada graças ao conjunto de trabalho social dispendido para tornar a terra um espaço "urbanizado" - para que se desenvolva alguma atividade capitalista na propriedade. disponibilidade de imóveis para locação e a verticalização nas áreas centrais, atendendo a demandas específicas - sobretudo no que tange à superutilização do lote urbano e a segregação sócio-espacial -, vazios urbanos estratégicos para especulação e a implantação de loteamentos clandestinos sem critérios urbanísticos ou infraestrutura adequada. A presença de um mercado imobiliário denota a diversificação do perfil de moradores, de modo a suprir as necessidades daqueles que irão assumir as funções geradas pelo arranjo agroindustrial e do agronegócio na cidade e região. O mesmo é notado na construção civil, na construção de moradias temporárias para promotores de vendas, estudantes e prestadores de serviços. Novos modos de vida são vendidos por incorporadoras e imobiliárias, através de empreendimentos em áreas específicas da cidade ${ }^{161}$.

O espaço construído se traduz no espaço socialmente construído, fruto do trabalho social, e a produção de cidade, tal como políticas públicas e práticas sociais, deve ser analisada simultaneamente como parte de uma rede de tensões e conflitos, o que caracteriza o processo de urbanização capitalista. Deste modo, FERREIRA define o espaço urbano enquanto produto do trabalho humano, onde se definem propriedades (localizações) e a localização enquanto base física de terra dotada de valor resultante do trabalho social investido em sua produção e de preço estabelecido pelo mercado, em função de seu valor de uso, através de sua posição no espaço urbano. A localização imprime grande importância na atribuição de valor à terra ${ }^{162}$. Na produção do espaço urbano (e não da terra), os espaços possuem valor de uso. Entretanto seu preço ou valor não serão decorrentes de custos de produção ou trabalho incorporado, mas da competição por propriedades, que dependerá da diferenciação do espaço urbano como um todo - diferenciações dadas por concentrações e polarizações, que influenciarão em localidades com preços maiores.

Na região sudeste do país, por exemplo, o custo da oportunidade de aquisição de terras agrícolas se dá pelos juros pagos por títulos públicos e pela renda que a área pode gerar através do arrendamento por usinas sucroalcooleiras para produção de cana-de-açúcar. Assim se garante o fornecimento de matéria-prima sem a necessidade de mobilizar capital em terra: o proprietário/produtor pode obter renda fixa sem riscos. Entretanto, é importante notar que a expansão da colheita influencia e é influenciada por leis do mercado internacional. Isso nos permite refletir sobre que proprietários de áreas agrícolas próximas a 
centros urbanos podem alterar o uso da terra agrícola para o urbano como alternativa de revenda da terra, de modo a não manter o capital imobilizado e obter lucros, parcelando o solo para fins urbanos, caso o mercado imobiliário forneça condições mais atrativas de transação que o agrícola, ou alternativas para se compartilhar os riscos de investimentos.

Assim como as cidades passaram a compor uma imagem, visando à atração do capital excedente para seu território, o país passou a fazer o mesmo com suas terras agrícolas, principalmente a partir dos 1980, com a adoção do modelo neoliberal, atraindo o interesse e investimento de empresas estrangeiras de agrobusiness. O Estado brasileiro precisava construir a imagem de que também era possível investir na produção agropecuária nacional. E de fato o fez. Atualmente, grandes corporações internacionais possuem investimentos e controlam uma parcela da produção agroindustrial nacional. Ao ser analisada a tabela de produção de açúcar e álcool das usinas da região de Ribeirão Preto (ver tabela 9), é possível extrair duas informações essenciais sobre sua contribuição ao complexo sucroalcooleiro. A primeira corresponde à flexibilização do destino da cana-de-açúcar, variando o enfoque conforme o preço e a demanda de açúcar e álcool em mercados financeiros. De acordo com KAY (2013), especulam-se os preços dos alimentos para cada cultura, conferindo a flexibilidade necessária para o capital, maximizando lucros e rendas e utilizando-se de mercados internacionais. A segunda corresponde ao fato de as usinas que processam a cana fazerem parte de empresas transnacionais, como é o caso da LDC Bioenergia S/A atuante em Sertãozinho, pertencente ao grupo Louis-Dreyfus. Com as fusões e aquisições de propriedades agrícolas por grandes empresas e corporações nos últimos 25 anos, grandes empresas privadas do setor agroindustrial obtiveram o controle das terras para onde as cidades se expandiam, gerando, como já visto, concentrações econômica e fundiária.

Em 2003, 112 mil proprietários detinham 215 milhões de hectares de terras. Em 2010, 130 mil proprietários controlavam 318 milhões de hectares, além de o número de áreas improdutivas ter aumentado mais do que o de áreas produtivas ${ }^{163}$. A Cosan, por exemplo, desde 2008, tem administrado aproximadamente 110 mil hectares de terras nos estados de Mato Grosso, Maranhão, Bahia, Piauí e São Paulo, através da criação da Radar, empresa responsável pela aquisição de pro-

\section{A TERRA COMO DENOMINADOR COMUM}




\begin{tabular}{|c|c|c|c|c|c|c|}
\hline $\begin{array}{l}\text { Usinas da Região } \\
\text { Administrativa } \\
\text { de Ribeirão Preto }\end{array}$ & Município & Cana $(t)$ & Açucar(t) & $\begin{array}{l}\text { Álcool } \\
\text { Anidro } \\
\left(\mathrm{m}^{3}\right)\end{array}$ & $\begin{array}{c}\text { Etanol } \\
\left(\mathrm{m}^{3}\right)\end{array}$ & $\begin{array}{c}\text { Total } \\
\text { Álcool } \\
\left(\mathrm{m}^{3}\right)\end{array}$ \\
\hline $\begin{array}{l}\text { 1-USINA SSÃO MARTINHO } \\
\text { SIA - AÇUUCAR E ÁLCOOL }\end{array}$ & Pradópolis & 6.732 .899 & 544.706 & 97.957 & 85.802 & 183.759 \\
\hline $\begin{array}{l}\text { 2-USINA SANTA ADÉLIA } \\
\text { S/A }\end{array}$ & Jaboticabal & 1.824 .542 & $\mathrm{~N} / \mathrm{I}$ & 107.309 & 42.219 & 149.528 \\
\hline $\begin{array}{l}\text { 3-PEDRA } \\
\text { AGROINDUSTRIAL S/A }\end{array}$ & Serrana & 3.276 .331 & 220.050 & 85.265 & 54.593 & 139.858 \\
\hline $\begin{array}{l}\text { 4-USINA DA BARRA S/A } \\
\text { AÇÚCAR E ÁLCOOL }\end{array}$ & Guariba & 4.415 .692 & 373.036 & 70.354 & 68.260 & 138.614 \\
\hline 5-LDC BIOENERGIA SIA & Sertãozinho & 3.593 .851 & 261.581 & 44.408 & 76.964 & 121.372 \\
\hline $\begin{array}{l}\text { 6-CENTRAL ENERGÉTICA } \\
\text { MORENO AÇUCAR E } \\
\text { ALCOOL LTDA }\end{array}$ & Luís Antônio & 3.132 .192 & 223.189 & 118.070 & 696 & 118.766 \\
\hline $\begin{array}{l}\text { 7-ANDRADE AÇÚCARE } \\
\text { ÁLCOOL S/A }\end{array}$ & Pitangueiras & 2.815 .798 & 207.963 & 35.939 & 72.909 & 108.848 \\
\hline 8-USINA BAZAN SIA. & Pontal & 2.733 .973 & 222.216 & 59.863 & 38.309 & 98.172 \\
\hline 9-USINA BELA VISTA SIA & Pontal & 2.573 .342 & 197.902 & 56.471 & 36.889 & 93.360 \\
\hline $\begin{array}{l}\text { 10-USINA SANTO } \\
\text { ANTONIO SIA }\end{array}$ & Sertãozinho & 2.284 .034 & 145.331 & 79.137 & 12.341 & 91.478 \\
\hline $\begin{array}{l}\text { 11-IRMÄOS TONIELLO } \\
\text { LTDA }\end{array}$ & Sertãozinho & 2.216 .883 & 168.068 & 27.179 & 55.785 & 82.964 \\
\hline $\begin{array}{l}\text { 12-USINA SANTA ADÉLIA } \\
\text { S/A }\end{array}$ & Jaboticabal & 1.829 .535 & 132.475 & 54.060 & 16.243 & 70.303 \\
\hline $\begin{array}{l}\text { 13-VIRALCOOL AÇUCAR } \\
\text { E ALCOOL LTDA }\end{array}$ & Pitangueiras & 2.273 .085 & 179.851 & 66.937 & 615 & 67.552 \\
\hline $\begin{array}{l}\text { 14-IRMÃOS TONIELLO } \\
\text { LTDA }\end{array}$ & Sertãozinho & 634.319 & $\mathrm{~N} / \mathrm{l}$ & $\mathrm{N} / \mathrm{l}$ & 52.173 & 52.173 \\
\hline $\begin{array}{l}\text { 15-USINA CAROLO S/A - } \\
\text { AÇUCAR E ALCOOL }\end{array}$ & Pontal & 1.806 .178 & 174.166 & 2.427 & 44.373 & 46.800 \\
\hline $\begin{array}{l}\text { 16-PITANGUEIRAS } \\
\text { AÇÚCAR E ÁLCOOL LTDA }\end{array}$ & Pitangueiras & 1.813 .337 & 180.020 & 28.222 & 14.407 & 42.629 \\
\hline $\begin{array}{l}\text { 17-PEDRA } \\
\text { AGROINDUSTRIAL S/A }\end{array}$ & $\begin{array}{l}\text { Santa Rosa } \\
\text { de Viterbo }\end{array}$ & 930.404 & 61.448 & $N / I$ & 40.246 & 40.246 \\
\hline $\begin{array}{l}\text { 18-USINA SÃO } \\
\text { FRANCISCO SIA }\end{array}$ & Sertãozinho & 972.271 & 66.746 & & 33.200 & 33.200 \\
\hline 19-LDC BIOENERGIA SIA & Jardinópolis & 899.824 & 71.547 & 8.640 & 21.138 & 29.778 \\
\hline $\begin{array}{l}\text { 20-DELOS DESTILARIA } \\
\text { LOPES DA SILVA LTDA }\end{array}$ & Sertãozinho & 271.351 & $\mathrm{~N} / \mathrm{I}$ & $\mathrm{N} / \mathrm{I}$ & 23.317 & 23.317 \\
\hline $\begin{array}{l}\text { 21-COMPANHIA } \\
\text { ALBERTINA MERCANTIL } \\
\text { E INDUSTRIAL }\end{array}$ & Sertãozinho & 889.048 & 70.797 & 7.697 & 15.440 & 23.137 \\
\hline $\begin{array}{l}\text { 22-CENTRAL } \\
\text { ENERGÉTICA RIBEIRÃO } \\
\text { PRETO, AÇÚCAR E } \\
\text { ÁLCOOL LTDA. }\end{array}$ & $\begin{array}{c}\text { Ribeirão } \\
\text { Preto }\end{array}$ & $\mathrm{N} / \mathrm{I}$ & $\mathrm{N} / \mathrm{I}$ & $\mathrm{N} / \mathrm{I}$ & $N / I$ & $\mathrm{~N} / \mathrm{I}$ \\
\hline $\begin{array}{l}\text { 23-DESTILARIA PIGNATA } \\
\text { LTDA }\end{array}$ & Sertãozinho & $\mathrm{N} / \mathrm{I}$ & $N / I$ & $\mathrm{~N} / \mathrm{I}$ & $\mathrm{N} / \mathrm{l}$ & N/I \\
\hline $\begin{array}{l}\text { 24-NOVA UNIÃO S/A } \\
\text { AÇÚCAR E ÁLCOOL }\end{array}$ & Serrana & $\mathrm{N} / \mathrm{I}$ & $\mathrm{N} / \mathrm{I}$ & $\mathrm{N} / \mathrm{I}$ & $\mathrm{N} / \mathrm{I}$ & $N / I$ \\
\hline
\end{tabular}

Tabela 9 - Produção de álcool por usinas na região administrativa de Ribeirão Preto, em 2012.

Fonte: Unica - União da Agroindústria Canavieira do Estado de São 
priedades com alto potencial de valorização e por disponibilizá-las a operadores rurais para cultivo de cana-de-açúcar, soja, milho e algodão. O não acesso de uma população empobrecida à terra gerou o excesso de contingente que sobrevive amontoado, compondo a cidade segregada e desigual. Segundo FERREIRA (2013), de 2008 a 2012 ocorreu um aumento vertiginoso do preço dos imóveis urbanos, decorrente de processos de especulação fundiária, especialmente porque a terra se manteve sem controle estatal, apesar das leis e dos planos que objetivavam o contrário.

Os latifundiários adotaram a mecanização dos modos de produção para produzirem mais e a preços competitivos, gerando uma redução do preço do produto e, consequentemente, do mercado econômico da região, pois aumentou os custos para pequenos proprietários de terra, forçando-os a mecanizarem sua produção. Os pequenos produtores, sem capital suficiente e sem as mesmas condições de acesso a novas tecnologias, não conseguiram produzir a mesma quantidade que os grandes latifúndios, nem conseguiram vender sua produção a preços competitivos. Como alternativas aos pequenos produtores, restaram-Ihes a venda de seus patrimônios a grandes empresas ou latifundiários, e o arrendamento, produzindo para as agroindústrias de beneficiamento (como as usinas).

A opção do arrendamento acaba sendo a mais frequente, de modo que a usina compra a planta industrial, utilizando-se da terra e da mão-de-obra baratas dos pequenos fornecedores, através de uma parceria agrícola, prevista no Estatuto da Terra, e estabelecendo-se um contrato, através do qual as usinas compram a produção dessas fazendas, beneficiam-na e preparam o produto para exportação ou outras cadeias industriais alimentícias ou energéticas ${ }^{164}$. Tal parceira visaria a proteger a parte que não detém a propriedade da terra, dando-Ihe autonomia para informar o valor dos custos que teve e, assim, não ser explorada pelo proprietário da terra. Os usineiros, no entanto, se aproveitam de tal lei, entrando como parceiros que não possuem a terra. O contrato entre a usina e o assentado acaba prejudicando o proprietário, pois ele não consegue determinar o preço de venda da cana-de-açúcar nem os custos com a produção, já que é a usina que detém tais informações. Assim, a usina acaba determinando o volume de produção que lhe convém e explorando a mão-de-obra do trabalhador e proprietário. No primeiro ano, o assentado recebe um valor definido. Porém, nos anos seguintes, a usina passa a cobrar os custos, inclusive da implantação
164. Se a questão da terra é central, presente e atual no meio agrícola, ela também é responsável pela tragédia urbana, conforme visto, resultante do processo de imigração rural-urbana dado pela industrialização e mecanização do campo - pelo modelo de desenvolvimentismo autoritário -, de desequilíbrios regionais, de ausência de reforma agrária, da expulsão de pequenos produtores em prol da concentração de terra pelos latifúndios, e da concentração de renda. 
do canavial, de modo que o agricultor acaba se endividando e correndo risco de perder sua própria terra.

É possível, diante dessas dimensões, apontar com KLAUSER (2013) que a forma liberal com que o Estado brasileiro conduziu a questão da agricultura no país, com o incentivo à expansão da monocultura, permitiu, em partes, o acesso das empresas transnacionais à propriedade da terra de forma direta e indireta. Direta no que se refere à compra de terras brasileiras pelas empresas (como a Monsanto, que possui uma área de 20 mil hectares às margens do Rio São Francisco, no Nordeste), e indireta pela aquisição de ações em empresas nacionais (como as associações e incorporações no setor sucroalcooleiro na região de Ribeirão Preto), ou o endividamento de produtores ou proprietários arrendatários brasileiros. É importante ressaltar que o controle sobre as terras gerado pela oligopolização dos setores do agronegócio não necessariamente significa o controle da propriedade da terra. Ou seja, a produção gerada na terra agrícola foi de fato internacionalizada, mas não o controle da propriedade agrícola.

A propriedade da terra sempre possuiu papel fundamental no desempenho do agronegócio e na tributação de produtores, assim como na formulação de políticas públicas de regularização fundiária e reforma agrária. A propriedade também se tornou fundamental para a constituição de um portfólio de investimentos para viabilização de novos projetos agropecuários e para as estratégias de aumento da produção agrícola (NOGUEIRA, 2011). Alguns aspectos devem ser destacados, como a terra enquanto fator de produção - representando uma imobilização de capital que fará sentido a uma atividade agropecuária ou agroindustrial - e o uso da terra enquanto reserva de valor - o que possui um longo histórico no agronegócio e no setor imobiliário, consistindo na exploração da terra para extração de capitais (através de arrendamentos), ou na real especulação em que o proprietário adquire terras para posterior revenda (o que tende a ter baixa liquidez, rentabilidade incerta e altos gastos de administração, além de impedir o desenvolvimento de empreendimentos urbanos e agropecuários).

Muitos autores afirmam que o agronegócio e o setor imobiliário possuem relações de destaque na produção de riqueza, dado seu potencial de produção relacionado à exploração da terra. Juntos, são responsáveis por quase $50 \%$ do PIB brasileiro, revelando semelhanças em determinados aspectos, como na dinâmica de investimento do agronegócio e da construção civil. 
Ambos os segmentos exigem capital intensivo, assim como também possuem em comum um modus operandi pautado da divisão social do trabalho, o que exige, cada vez mais, a especialização de alguns e a exploração laboral de outros. O empresário que queira comercializar seu produto (agrícola ou oriundo de empreendimento imobiliário) necessita capital para financiar o seu projeto (construção ou produção agrícola) e tem seu retorno financeiro vinculado à performance de seu negócio - ou seja, ao sucesso na venda dos respectivos produtos. Obviamente, existem diferenças micro e macroeconômicas importantes a serem consideradas. Apesar disso, tanto o agronegócio quanto o setor imobiliário possuem a mesma dinâmica de investimento, logo as estruturas criadas para financiá-los tendem a se parecer. Por conta da relevância econômica desses setores, reiteradamente têm seu desenvolvimento impulsionado por incentivos e estímulos governamentais. E é a partir de tal aspecto que eles passam a se diferenciar, pois apresentam riscos completamente distintos, o que dificulta o desenvolvimento de ambos com incentivos similares. Enquanto o imobiliário ocupa posição de destaque na alocação da poupança brasileira, o agronegócio necessita de maiores linhas de crédito para ampliar seu desenvolvimento, tornando-se um tipo de investimento bastante específico, voltado para o governo (através do Banco do Brasil) e para investidores específicos (trading companies).

O setor imobiliário apresenta um maior amadurecimento de suas estruturas, além de um relacionamento mais consolidado com o mercado de capitais brasileiro. Deste modo, muitos autores acreditam na possibilidade de o agronegócio alcançar volumes de operações de mercado de capitais em níveis semelhantes aos do imobiliário, que atualmente vive um momento de expansão, com seus títulos e valores mobiliários sendo disputados por diversos investidores do mercado (o sucesso da captação do fundo de investimento imobiliário do Banco do Brasil é um bom exemplo). Nesse processo, o agronegócio reproduz a experiência do mercado imobiliário, seja pelo aprimoramento dos incentivos governamentais existentes, seja pela criação (e aperfeiçoamento) de estruturas de securitização, adaptando determinados produtos do mercado imobiliário (como certificados de recebíveis do agronegócio - CRI - do Agronegócio e FII Rural ${ }^{165}$, cujos ativos apresentam origem agrícola, ou LCl Agro, nomenclaturas específicas de transações imobiliárias) e estreitando ainda mais as semelhanças e intercomunica-
165. Tais fundos só são utilizados no agronegócio através de empresas, de modo a facilitar a captação de linhas de financiamento de bens de capital para o empreendimento e oferecer transparência aos stakeholders, para facilitar e favorecer o acompanhamento dos cotistas dos fundos através de ações listadas em bolsas de valores NOGUEIRA(2013) afirma que a divulgação do uso de tais fundos no agronegócio deveria ser incentivada através de políticas públicas específicas, de modo a regulamentar através de instituições financeiras públicas as operações do produto no agronegócio, visando aumento da produção e da produtividade dos circuitos do setor. 
ções de ambas as esferas. Porém é imprescindível ressaltar que acabam perpassando por um objeto fundamental de interesse comum: a propriedade da terra.

Existe um processo de especulação imobiliária no campo e de transações relacionadas à terra que muito se assemelham ao que ocorre dentro do espaço da cidade. Do mesmo modo que o valor de um lote urbano varia de acordo com infraestrutura, localização, acessibilidade e equipamentos urbanos, a terra agrícola varia com a proximidade à rede urbana, com a disponibilidade de infraestrutura e com a localização da produção. Diferentemente do setor imobiliário, o valor da terra agrícola varia também com o valor da produção regional, com os preços da produção e a demanda de mercados e com os preços das commodities no mercado financeiro. Assim, são valores de mercado que controlam as alterações do preço de venda da terra agrícola que tornarão o processo de alteração de uso do solo vantajoso ou não para o proprietário. O preço da comercialização da terra, portanto, está relacionado com o valor da terra agrícola, tendo em vista sua produção - já que estão intimamente relacionados - e também a dinâmica imobiliária da região e da cidade.

O mercado de terras também é um importante fator, uma vez que é formado pelas propriedades existentes, pelos proprietários e compradores. O preço da terra é formulado de acordo com alguns elementos, como as condições de regularização dos títulos de propriedade na região, a fertilidade do solo, a infraestrutura de transportes e comunicações, as distâncias de centros consumidores e a aptidão da área para desenvolvimento de atividades agropecuárias. Em outras palavras, há um preço da terra que não é mais relacionado à "renda da terra", mas um pagamento dado por sua localização ${ }^{166}$, cuja capacidade aglomerativa de combinar socialmente os meios de produção e de reprodução passa a ser vendida como mercadoria, dotada de valor de troca. Há também outra forma de renda denominada renda-monopólio. Esta renda não resulta diretamente no trabalho social investido, mas de sua única condição natural, que pode gerar um ganho excedente sem demandar esforços do proprietário, associada à localização privilegiada de uma empresa (permitindo-a cobrar preços acima da concorrência de mercado) e ao desejo e capacidade aquisitiva dos compradores, independentemente do valor do produto ou do preço geral da produção.

Contudo, a conjuntura atual e as perspectivas de mercado futuro das culturas de propriedades vizinhas, ou de um contexto regio- 
nal, também ajudam a definir o preço da propriedade, de modo que o preço reflete a renda esperada para o futuro empreendedor que tenha interesse em adotar a atividade econômica predominante, compondo um verdadeiro jogo especulativo.

Tal situação no mercado de terras agrícolas é bastante semeIhante àquilo com que normalmente se depara no mercado imobiliário no interior da malha urbana. O processo de reprodução da cidade capitalista necessita veementemente das intervenções do Estado para a obtenção das condições de realização das atividades no território, já que possui papel fundamental na organização, territorialização e regulação das atividades e arranjos produtivos do capital, através do planejamento e de investimentos públicos ${ }^{167}$.

Se o preço da terra se encontra atrelado à cotação do produto na bolsa de valores de commodities, a propriedade agrícola também acaba articulada a um mercado financeirizado, de modo que a expansão das escalas produtivas e a compra e venda de terras acabam se configurando em um verdadeiro jogo de azar, devido à existência de diversas variáveis envolvidas, tornando o investimento uma operação de alto risco financeiro. A demanda de compra de investidores e variações no câmbio, ou juros pagos por títulos também afetam diretamente o mercado de terras. Em situações de queda de juros, os ativos reais podem se tornar atrativos enquanto investimentos, o que pode gerar alta de preços em imóveis tanto urbanos quanto rurais - o que reforça a ideia de que as relações cidade-campo foram reestabelecidas e associadas ao mercado internacional -, configurando as chamadas "bolhas imobiliárias", que geram consequências diretas na (re)produção de cidade (NOGUEIRA, 2011).

\begin{abstract}
Atualmente o Brasil passa por um processo similar com o aumento dos preços dos terrenos e imóveis urbanos, tendo em vista o crescimento da oferta de crédito imobiliário. Existem dúvidas se o movimento é uma bolha, visto que o aumento de preços está apoiado em uma demanda reprimida por imóveis que começa a ser atendida. A alta demanda por terrenos urbanos pode estar afetando o mercado de imóveis rurais em regiões com maior densidade populacional, elevando os preços das terras para a agropecuária ${ }^{168}$.
\end{abstract}

É notória a relação entre o agronegócio - as grandes empresas transnacionais, empresas familiares nacionais, proprietários de latifúndios, arrendatários - e o mercado de terras, tendo em vista não só o controle de terras agricultáveis necessárias para o aumento da produti-
167. Segundo HARVEY (1982), é o direito à renda que a terra permite e produz que passa a ser negociável e comercializado, dada a localização e o uso da terra. Todo proprietário de terra, assim, obtém um ganho pelo simples fato de ter a terra (FERREIRA, 2013, p.75). Para Fisette, a "construtibilidade" do solo é destacada como decorrente de regras de zoneamento criadas pelo poder público que permitem mais ou menos potencial construtivo. 0 incorporador-construtor captura para si uma renda a partir da exploração da terra do proprietário fundiário, de modo que o capitalista retenha parte do sobrelucro possibilitada pela melhor terra.

168. NOGUEIRA, 2011. 
vidade agrícola, mas também o controle da reprodução de cidade, que se expande pelo espaço através das terras agrícolas. Ocorre, então, nessa franja, a alteração do uso do solo, de agrícola para urbano. Essa discussão permite evocar HARVEY (2011): "a realização de novas geografias implica mudanças na terra e sobre ela”. Os proprietários de terra podem se beneficiar enormemente com o aumento de valores dos terrenos, das rendas crescentes das terras e dos recursos que possuem, que variam de acordo com os investimentos no lugar e em investimentos que alteram as relações de espaço, agregando valores à terra, como infraestrutura e acessibilidade. Os investimentos na terra, seu retorno e a necessidade de realização de ganhos especulativos se tornam processos bastante atrativos aos proprietários.

Com a expansão das áreas cultiváveis para outras áreas do país, a alteração do uso da terra outrora agrícola tornou-se um importante nicho para o mercado imobiliário regional. A alteração de uso da terra, do agrícola para o urbano, pressupõe também uma alteração no preço da terra, tendo como base o fato de que uma propriedade agrícola inclui o preço da mercadoria terra e seu potencial de produção voltado ao agronegócio, alterando-se e compondo um valor total da venda dos lotes de um empreendimento produzido naquela localidade. Assim, o preço da terra tende a aumentar (através do valor geral de venda - VGV - do empreendimento), e o preço dos lotes também. Porém ao longo do tempo, através de processos especulativos, da construção de equipamentos públicos e do desenvolvimento do bairro em questão.

Deste modo, a mercadoria lote não é produzida como outra qualquer pela indústria, mas está articulada e relacionada com o espaço e contexto urbano onde está localizada, pois não possui os mesmos mecanismos de comercialização das outras mercadorias. Ainda que seja socialmente produzida, a moradia ainda está atrelada à terra. Portanto a terra possui importância, não apenas como equivalente de capital fixo - suporte físico destinado a alguma atividade de acumulação -, mas também enquanto propriedade negociável em transações financeiras e econômicas. Ela se tornou um bem de amplo interesse para grandes empresas, caracterizando-se como um importante denominador comum entre o agronegócio, a produção de cidade e o mercado imobiliário. 


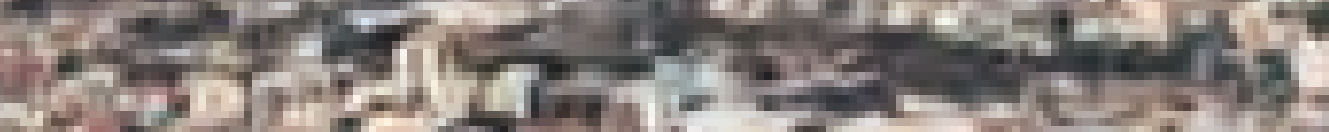

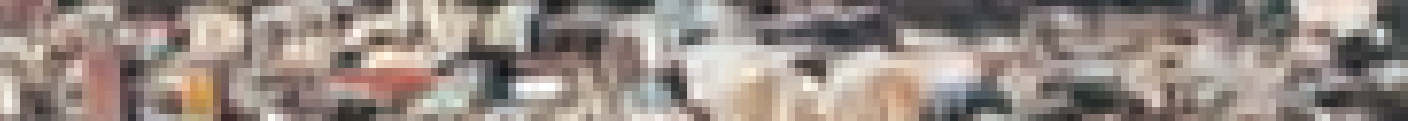

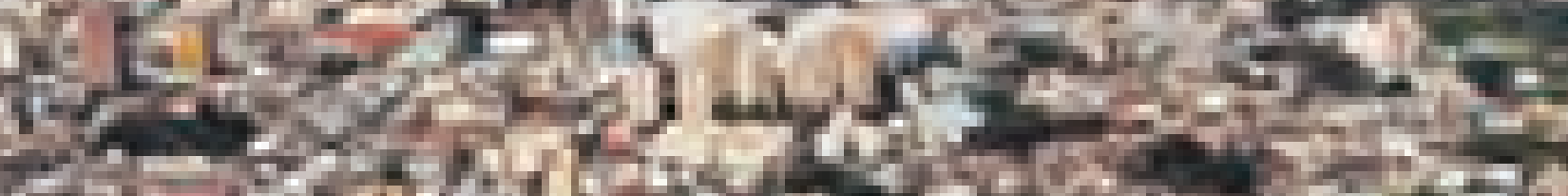

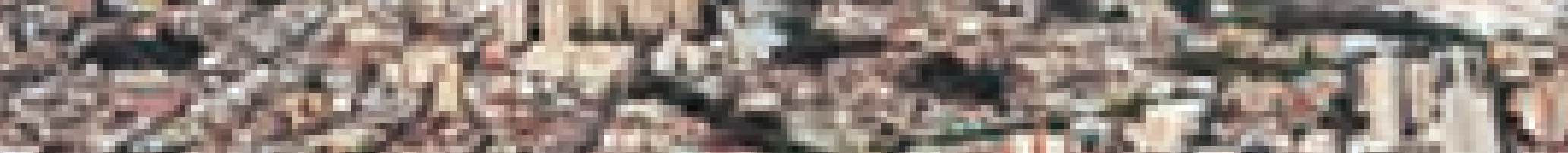

If

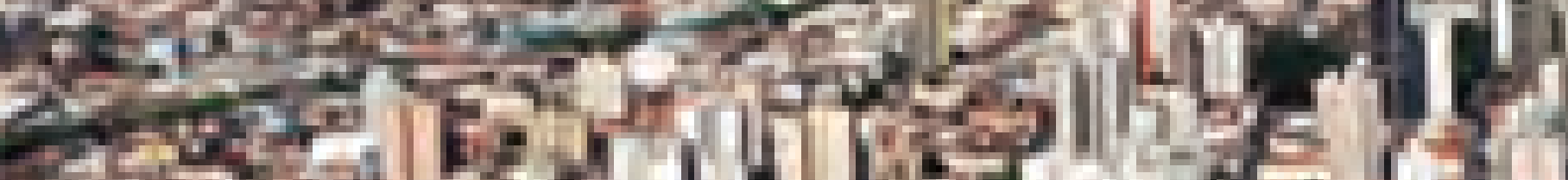

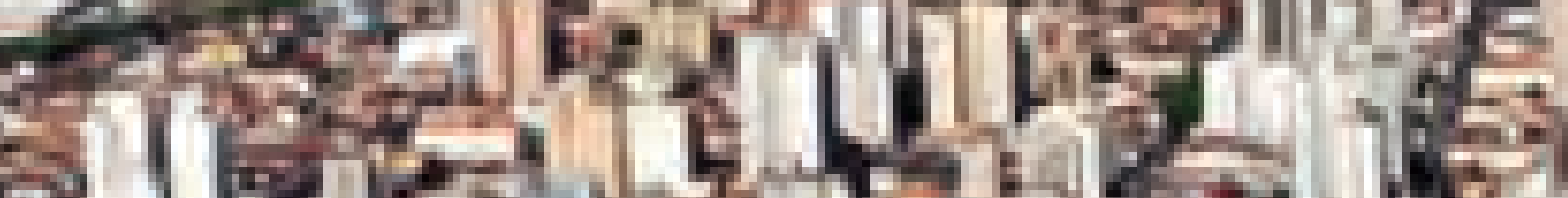

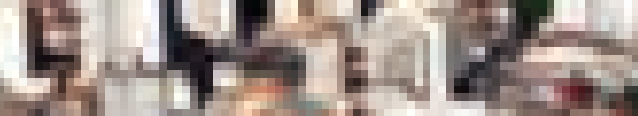

(n+1

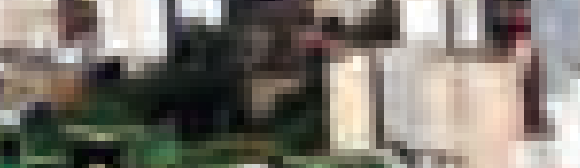

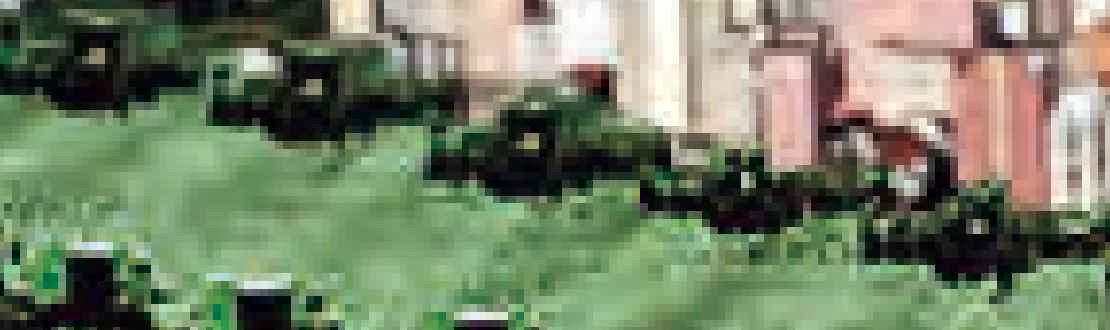

달 ज小

(4)

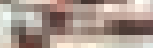

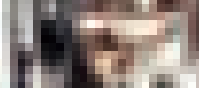

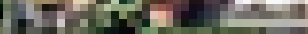

Milion.

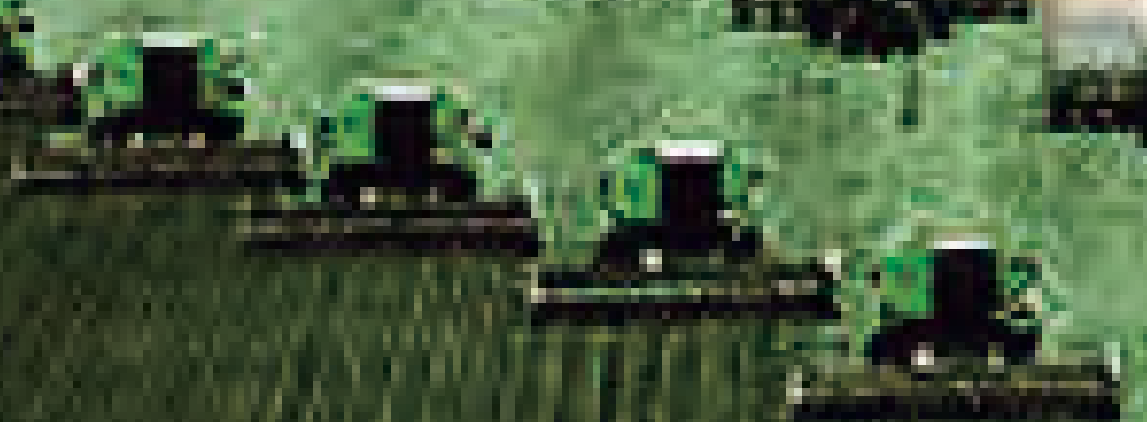

Fotomontagem: Arquivo pessoal.

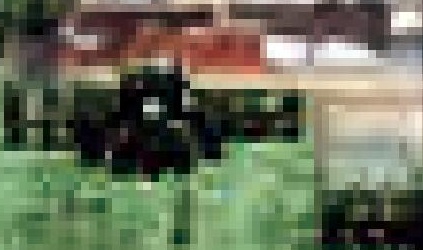

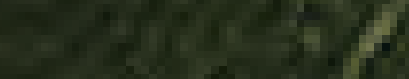

ext

(5) 


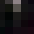

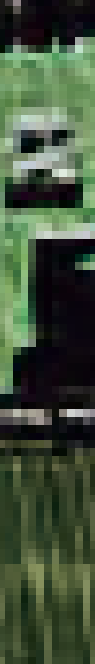

$+1$ ( 
balanço e conclusões 
A reunião caminhava para um desfecho positivo. $O$ banqueiro bocejava feliz com os tantos acordos fechados e com o quanto o banco lucraria com aquele empreendimento. A representante da prefeitura mordia os lábios ao pensar nos benefícios que aquele projeto traria para a construção da imagem de uma cidade próspera e cheia de oportunidades de investimentos e captação de recursos. Eufóricos, os empresários dariam continuidade às conversas na casa do empreiteiro, localizada em um condomínio fechado, um local mais privado e menos corporativo para conversas mais sigilosas sobre a valorização das terras e possíveis brainstorms para encontrar alternativas mais lucrativas aos empreendimentos imobiliários e agrícolas de ambos. O corpo técnico, exausto, agrupava toda a papelada, e cada um sonhava com um happyhour para relaxar e conversar sobre outros assuntos, tentando se esquecer dos valores que os empresários lucrariam com o empreendimento e o quão irrisória seria a participação de cada um dos profissionais responsáveis pela execução do projeto nos lucros da empresa com a venda das unidades habitacionais.

Tornava-se claro que o que estava em disputa naquela reunião era a reprodução do capital através do uso da terra, aproximando os 
interesses de empresas que estavam intimamente relacionadas a produções resultantes diretamente do uso e propriedade do solo. Além disso, dela foram extraídos outros pontos que merecem significativa relevância no que tange à urbanização, à noção de rede de cidades e à relação entre cidade e campo.

A expansão da agropecuária correspondeu a um importante processo para a conformação do território brasileiro, beneficiando a produção com o aumento das áreas de cultivo e também com a ampliação da atuação de estruturas governamentais, industriais e de produção no espaço, ressignificando e reconfigurando as relações entre cidade e campo.

Os processos de mecanização do campo e de industrialização da produção agrícola também foram essenciais para a rarefação da fronteira dicotômica entre cidade e campo. Quanto mais se intensificou o capitalismo no campo, mais urbana se tornou a regulação da agropecuária, sua gestão, normatização, produção e exportação, assim como se acentuaram velhos conflitos e problemas no ambiente das cidades. Do mesmo modo, quanto mais dinâmica a reestruturação produtiva e mais globalizados os círculos espaciais da produção e de cooperação, mais complexas se tornaram as relações cidade-campo, aprofundando-se a divisão social e territorial do trabalho, remodelando-se o território e reorganizando-se o sistema urbano, resultando numa rede de aglomerações urbanas para realização da produção destinada ao agronegócio globalizado.

A ampliação do território capitalista no Brasil se deu graças a políticas e estratégias de ocupação do interior, através da necessidade de expansão das lavouras voltadas para um modelo de exportação. Se a expansão do campo constituiu o primeiro movimento no processo de urbanização do espaço e do território brasileiros, a mecanização seguida da industrialização do campo alterou profundamente a relação cidade-campo em vários aspectos, desde os modos de produção às formas de controle e dominação urbana sobre o espaço agrícola e a sua nova divisão do trabalho.

Nos últimos quarenta anos, o Estado brasileiro reorganizou seus arranjos produtivos pelo território agrícola do país em função da melhor reprodução de capital, decorrente da alteração da lógica de produção fordista para um regime de acumulação flexível, o que demandou uma reestruturação das forças produtivas de trabalho. Acabaramse privilegiando determinados pontos do espaço, visando a focos, con- 
centração e centralização de investimentos; capitais, bens de consumo e populações. Assim, a produção de cidades passou a ter outras funções e papéis no que diz respeito à economia e ao mercado financeiro globalizados. Suas vinculações com o exterior não são, necessariamente, realizadas com intervenção de esferas estaduais ou federais, ainda que estas apoiem constantemente as atividades inerentes ao comércio exterior.

A dinâmica do mercado agrícola mundial, sobretudo o do açúcar, trouxe grandes consequências na produção nacional, aumentando a tendência de concentração dos meios de produção, gerando uma reestruturação produtiva das cadeias de agroindústrias sucroalcooleiras. As usinas e destilarias familiares, para sobreviverem à crise do açúcar de 2008, foram incorporadas a grandes empresas do agronegócio, que possuíam capital suficiente para não se desestabilizarem, o que gerou também uma concentração fundiária e acentuou ainda mais os conflitos relacionados à divisão de terras no Brasil. O conflito se tornou ainda mais complexo com a transnacionalização de empresas do setor, inserindo empresas estrangeiras nas cadeias produtivas, através de fusões e aquisições, de modo que muitas delas passaram a deter controle sobre a produção em terras brasileiras.

O agronegócio correspondeu - e ainda corresponde - a um momento importante da reprodução espacial da sociedade urbana, sendo uma das formas pela qual a urbanização da sociedade atual produz e conquista o espaço: legitimou o processo de urbanização do território com suas aquisições e seus conflitos, articulando a produção e trabalho agrícolas e a função da terra, tanto à esfera financeira quanto à imobiliária. A terra se tornou ativo financeiro, assim como local de oportunidades de investimentos, tanto no setor agrícola quanto no imobiliário.

A propriedade da terra constitui elo essencial entre o agronegócio e o mercado imobiliário. Em ambos os mercados é possível encontrar pontos bastante comuns, sobretudo no que tange à utilização e exploração da terra enquanto plataforma de reprodução de capital, ativo financeiro e objeto de especulação imobiliária, na cidade e no campo.

As dinâmicas de acumulação de capital resultaram das iniciativas de diversos atores - como proprietários fundiários, incorporadores, construtoras, financeiras, imobiliárias e setor público - com interesses particulares sobre o território urbano, reproduzindo suas riquezas e 
comercializando a cidade. A produção de empreendimentos imobiliários nas cidades da região passou a gerar commodities ofertadas pelo espaço urbano, frutos de um mercado financeirizado. Nas zonas de expansão urbanas onde ocorrem as alterações de uso do solo, do agrícola para o urbano, a definição de implantação de polos de atividades específicas (como shoppings) ou equipamentos públicos (como parques, serviços, monumentos e terminais de transporte público) irão desencadear os processos de ocupação urbana e até mesmo de especulação imobiliária. Nessas áreas de expansão é possível notar, com maior evidência, o caráter da cidade enquanto negócio - imobiliário, de investimento, de (re)produção de capital, de flexibilização de investimentos e especulativo -, através da venda de loteamentos e empreendimentos.

No período mais recente da história do capitalismo, o Estado atua enquanto gestor, estabelecendo condições para a realização ou não de atividades indispensáveis à organização, e reprodução das forças produtivas. Desse modo, o capital privado por si só não tem a possibilidade de estruturar o território de forma eficiente para a acumulação, sendo necessárias algumas intervenções do Estado. Este alterou seu enfoque, permitindo-se ser administrado semelhantemente a um negócio, tendo sua atuação focada não mais na preservação de interesses da sociedade como um todo (saúde, proteção social, educação, emprego e renda), mas nos interesses de uma parcela específica de agentes, cujos negócios dependem profundamente dessa atuação que repassa e concentra lucros e dividendos a tais agentes, em troca da socialização das dívidas na esfera pública, dilapidando os recursos e o espaço econômico do Estado.

Dentro da lógica reprodutiva do capital, tanto o território regional quanto o urbano passaram a ser vistos como objetos de investimentos, em que se notam concentrações na aplicação de recursos e capitais. Tais espaços, sob a regulação do Estado, necessitam se organizar para atrair e receber os capitais em nível regional e global. Do contrário, correm o risco de absorver os fluxos de capitais, ocasionando um contexto complicado de possível estagnação de seu crescimento econômico e desenvolvimento social. Conforme visto, nos últimos cinquenta anos, o Estado brasileiro reorganizou seus arranjos produtivos pelo território, em função da melhor reprodução de capital, passando de uma lógica de produção fordista para um regime de acumulação flexível, o que demandou uma reestruturação das forças produtivas de trabalho. 
Deste modo, acabou-se privilegiando determinados pontos do espaço, visando focos de investimento, concentração e centralização de investimentos, capitais, bens de consumo e populações em cidades e em áreas específicas dentro da malha urbana.

A lógica da valorização do solo, que tem como finalidade a comercialização da terra, tornando-se a principal responsável pela abertura de novas fazendas, chácaras e bairros, além da expansão do tecido de uso urbano como um todo, através do parcelamento de glebas por empreendimentos imobiliários, transformou a terra rapidamente em ativo financeiro, no final do século XIX.

A produção agrícola, que outrora dependia fortemente das condições naturais para sua realização, com a modernização e mecanização da atividade, passou a constituir-se etapa fundamental de uma linha de produção industrial, tornando o campo uma grande planta industrial, voltada para a produção de matéria-prima para outros produtos industrializados. No processo de mecanização e modernização do campo está localizado o desenvolvimento de um complexo de indústrias especializadas para o cultivo agrícola, dentre elas siderúrgicas, metalúrgicas, energéticas, computacionais e biotecnológicas, correspondendo a um nicho que antecede a etapa de cultivo.

As mudanças no padrão de produção agrícola reconfiguraram as relações entre cidade e campo, extinguindo - ao menos no interior paulista - a noção de ruralidade, dissolvendo as fronteiras entre campo e cidade, caminhando para uma urbanização total do espaço, tornando o campo algo urbano e peça chave de diversas atividades econômicofinanceiras relacionadas à propriedade da terra - desde a produção de alimentos e matérias-primas para outros segmentos industriais, até mesmo à produção de loteamentos e de habitação.

Conforme visto, a agroindústria desencadeou diversos processos que interferiram no campo, e trouxe consequências às cidades da rede urbana. No que corresponde à mão-de-obra, gerou um excedente que foi absorvido pelas áreas urbanas, intensificando processo de favelização e de aumento de mão-de-obra para serviços não especializados. Com a organização de arranjos produtivos, a produção agrícola passou de subsistência para mercadoria internacional. O processo de industrialização, apoiado inclusive pelo próprio Estado, concentrou a propriedade da terra nos grandes latifúndios, mas isso não excluiu médios e pequenos proprietários, pois as usinas, no caso sucroalcooleiro, necessitavam terras baratas para o cultivo de cana. O Estado conti- 
nuou atuando, não mais enquanto regulador, mas como articulador entre produtores, investindo e criando políticas para a inserção do pequeno e médio proprietário aos circuitos de produção, visando ao crescimento econômico.

Indubitavelmente, as relações entre cidade e campo se modificaram. O território conformado por tais relações é de fato urbano, ao mesmo tempo em que parece tratar-se de um território dividido entre proprietários, em que apenas uma pequena parcela é de fato pública: áreas de preservação, parques, praças e vias de circulação. Das terras agrícolas atuais, grande parte está sob o poder de grandes empresas agroindustriais e construtoras imobiliárias, desdobrando-se o lote industrial em pequenas propriedades residenciais, comerciais, de serviços e industriais (lotes) particulares e produzindo espaços públicos por excelência - ruas, praças, lotes institucionais.

No que se refere ao espaço, ocorreram mudanças significativas em diversos níveis, do local ao global. Com a crise da produção fordista e a alteração do sistema de acumulação para um modelo flexível, a produção agroindustrial se submeteu a variações de um mercado global, tornando-se um negócio financeirizado, dado seu caráter de abastecimento de mercados consumidores em âmbito mundial.

O direcionamento de investimentos estatais para determinadas regiões do país, do ponto de vista mais amplo, constituiu-se enquanto política de desenvolvimento, fazendo com que cidades localizadas fora das regiões metropolitanas se organizassem de modo a atenderem à demanda de produção industrial e agroindustrial, caracterizando o processo de urbanização do território brasileiro. Deste modo, o desenvolvimento econômico de regiões do interior brasileiro está relacionado com um processo de transição de indústrias e atividades de grandes centros metropolitanos para outras áreas do território, caracterizando o processo de especialização da produção.

Em escala municipal, algumas áreas da cidade acabaram captando mais recursos do que outras, dada a importância das atividades específicas que comportavam. O mesmo ocorreu com a habitação e com o processo de produção de cidade através de loteamentos. Porém, em uma região onde a produção agrícola é fundamentalmente agronegócio, a produção de cidade passa a estabelecer com essa mesma produção um ponto em comum: a terra em sua caracterização enquanto ativo financeiro.

Tanto a terra como o trabalho são alguns dos elos entre a pro- 
dução agrícola e a produção de cidade. Seu uso e ocupação estão relacionados a mercados financeiros, que permitirão o desenvolvimento de uma atividade ou outra com base em processos especulativos imobiliários e na dinâmica do mercado de produtos agrícolas, tal como as cotações do açúcar e do álcool em bolsas de valores. Tal desenvolvimento está relacionado diretamente com o preço da terra, tendo em vista sua localização e seu potencial produtivo para a economia agrícola da região, ou para o mercado imobiliário, conforme visto nos casos da produção de loteamentos e empreendimentos imobiliários localizados nas áreas de expansão das cidades de Sertãozinho e Ribeirão Preto, o que pode ser interpretado como uma alternativa de investimentos ao mercado financeirizado das commodities. A produção de cidade, nesse sentido, é vista como alternativa de investimentos, de modo que a alteração de uso e ocupação do solo possa vir a beneficiar os proprietários de terras - grandes latifundiários e grandes empresas, inclusive transnacionais.

As fazendas modernas se tornaram verdadeiras plantas industriais, nada restando de um campo que se contrapõe à cidade. $\mathrm{O}$ mercado imobiliário e o agronegócio definiram todo o espaço passível de comercialização, constituindo território livre para a reprodução de capital, seja produzindo grãos, seja produzindo e reproduzindo cidade. A reprodução da cidade tornou-se alternativa para as grandes empresas que detêm poder sobre latifúndios e propriedades que circunvizinham a mancha urbana e que também controlam a produção agrícola transnacional. Com toda a sua gama de conflitos, tal reprodução pressupõe uma alteração do uso do solo que desencadeia novas relações no território, reproduzindo e reestruturando constantemente o espaço capitalista. 
referências 
ADORNO, T. W.; HORKHEIMER, M. Dialética do Esclarecimento. Tradução Guido de Almeida, Rio de Janeiro: J. Zahar, 1988.

ÁGUAS, C. P. Terra e estrutura social no Brasil: exclusão e resistência das comunidades negras quilombolas. Revista Angolana de Sociologia, Angola, p. 131-148: outubro de 2012.

ALENCAR, M. T., LANDIM, M. F. M. URBANIZAÇÃO E AGRONEGÓCIO: Petrolina, a cidade está em cena. Revista Equador, Universidade Federal do Piauí, vol. 1, n. 1, p. 4-22, Piauí: jun/dez de 2012. Disponível em: <http://www.ojs.ufpi.br/index.php/equador/article/view/896>. Data de acesso: 15 de jul. 2013.

ALVES, F. Por que morrem os cortadores de cana. Saúde e Sociedade, v. 15, n. 3, p. 90-98, set/2006.

ARANTES, O. VAINER, C. MARICATO, E. A Cidade do Pensamento Único: Desmanchando consensos. ed. 1, Petrópolis: Vozes, 2000.

ARRUDA, Z. A. As cidades na região de expansão do agronegócio e as novas territorialidades. Revista Territorium Terram, Universidade Federal de São João Del Rey. n. 1, vol. 1, p. 72-94, out/mar. 2012/2013. Disponível em: <www.ufsj.edu.br/cogeo/revista_territorium_terram.php>. Data de acesso: 17 de jul. 2013. 
ARROYO, M. M. Dinâmica territorial, circulação e cidades médias. In: SOBARZO, O., SPÓSITO, E. S., SPOSITO, M. E. B (Orgs). Cidades Médias: produção do espaço urbano regional. Ed. 1. São Paulo: Expressão Popular, 2006.

ASSUNÇÃO, V. A necessidade da Reforma Agrária para o Brasil: entrevista. [jan. 2014]. O Globo. Disponível em: <http://www.mst.org.br/node/15639> Data de acesso: 21 de julho de 2014.

BATISTA, F. Lucro da Maubisa salta $88 \%$ em 2011. Valor Econômico, 10 de abril de 2012. Disponível em: <http://www.valor.com.br/agro/2610018/lucro-damaubisa-salta-88-em-2011 > Data de acesso: 21 de julho de 2014.

BATISTA, F.; CAETANO, M.; FERREIRA, C.; e MENDES, L. H. Empresas ligadas ao campo superam o lbovespa em 2013. Valor Econômico. p. B12, São Paulo: 13 de jan. 2013.

BEABISA PECUÁRIA, AGRICULTURA \& EMPREENDIMENTOS. [Dados sobre a empresa]. Disponível em: <http://www.beabisa.com.br/>. Data de acesso: 12 de dez. 2012.

BEZZON, J. C. F. O planejamento para o desenvolvimento local em cidades "glocais" brasileiras: em direção ao novo modus operandi de gestão e produção da cidade. 272 p. Tese de doutorado (Teoria e História da Arquitetura e do Urbanismo), Escola de Engenharia de São Carlos, Universidade de São Paulo, São Carlos: 2008.

Política e planejamento do desenvolvimento urbano da cidade de Ribeirão Preto no período de 1983 a 2002: Análise e crítica do modelo de verticalização periférica ancorada e informatizada. 208 p. Dissertação de mestrado (Teoria e História da Arquitetura e do Urbanismo), Escola de Engenharia de São Carlos, Universidade de São Paulo, São Carlos: 2002.

BIAGI FILHO, M. Recuperação do setor virá pelo açúcar: entrevista. [27 de março, 2014]. Nova Cana, Valor Econômico. Entrevista concedida a Fernando Lopes. D i s p o n v e I e m : http://www.novacana.com/n/industria/usinas/recuperacao-setor-acucar-mauriliobiagi-270314/ > Data de acesso: 24 de julho de 2014.

B I OSE V. L D C o m mod i t i e s. D i s p o n ível e m : <http://www.ldcsev.com/inter.php?id=60\&ct=55>. Data de acesso: $12 \mathrm{de} \mathrm{dez.}$ 2012.

CALIL JÚNIOR, O. O centro de Ribeirão Preto: os processos de expansão e setorização. p. 209. Dissertação de mestrado (Teoria e História da Arquitetura e do Urbanismo), Escola de Engenharia de São Carlos, Universidade de São Paulo, São Carlos: 2003.

CAMARGO, S. Trabalho imaterial e produção cultural: a dialética do capitalismo tardio. São Paulo: Annablume, 2011.

CANNALONGA, F. As novas e velhas contradições do etanol. Brasil de fato. 13 de jun. 2011. Disponível em: < http://www.brasildefato.com.br/node/6577 > Data de acesso: 09 de mai. 2014. 
CASTRO, I.; CORRÊA, R.; GOMES, P. C. (Orgs.). Geografia: conceitos e temas. Rio de Janeiro: Bertrand Brasil, 2000.

CAVALINI, L. Bolsa de usineiros já eleva preço do álcool. Folha de São Paulo, 24 d e ju.$\quad 1999$. D i s p o n íve I e m : <http://www.novacana.com/n/industria/usinas/tradicionais-usineirosminoritarios-030214/> Data de acesso: 11 de jun. 2014.

CERQUEIRA, B. Por um capital mais barato. Dinheiro rural, ed. 67, jun. 2010. Disponível em: <http://revistadinheirorural.terra.com.br/edicao/67> Data de acesso: 20 de mar. 2013.

Visão “imobiliagro”. Revista Capital Aberto, ano 10, n. 113, jan. 2013.

D i s p o n í v e l e m : $<$ www.capitalaberto.com.br/ler_artigo.php?pag=2\&sec=136\&i=5235>. Data de acesso: 21 de jul. 2014.

COMPANHIA NACIONAL DE ABASTECIMENTO (Brasil). A Importância da Agricultura Familiar no Desenvolvimento dos Municípios. Mai. 2013. Disponível em: <http://i-uma.edu.br/blog/2013/05/a-importancia-da-agriculturafamiliar-no-desenvolvimento-dos-municipios/ >. Data de acesso 16/062014.

COPERSUCAR se une a empresa dos EUA e cria gigante mundial do etanol. UOL Notícias, São Paulo: 05 de nov. 2013. Disponível em: <http://economia.uol.com.br/noticias/redacao/2012/11/05/copersucar-se-une-aempresa-dos-eua-e-cria-gigante-mundial-do-etanol.htm>. Data de acesso: 11 de junho de 2014.

DIAS, L. Redes: emergência e organização. In: CASTRO, I.; CORRÊA, Roberto; GOMES, Paulo César (Orgs.). Geografia - conceitos e temas. Rio de Janeiro: Bertrand Brasil, 2000. p. 141-164.

EGLER, C. A. G. Questão regional e gestão do território no Brasil. In: CASTRO; CORREAA; GOMES, P. C. (Orgs.). Geografia - conceitos e temas. Rio de Janeiro: Bertrand Brasil, 2000. p. 207-239.

ELIAS, D. Globalização e agricultura: $A$ região de Ribeirão Preto - SP. Universidade de São Paulo, São Paulo: EdUSP , 2003.

Globalização e fragmentação do espaço agrícola do Brasil. Scripta Nova: Revista Electrónica de geografía y ciencias sociales. Universidad de Barcelona, vol. X, núm. 218, $1^{\circ}$ de ago. 2006. Disponível em: <http://www.ub.edu/geocrit/sn/sn-218-03.htm>. Data de acesso: 09 de dez. 2012.

Novas dinâmicas territoriais no Brasil agrícola. In: SPOSITO, E. S.; SPOSITO, M. E.; SOBARZO, O. (Orgs.). Cidades médias: produção do espaço urbano e regional. 1 ed. , v. 1, p. 279-303, São Paulo: Expressão Popular, 2006.

ELIAS, D., PEQUENO, R. Desigualdades socioespaciais nas cidades do agronegócio. Revista Brasileira de Estudos Urbanos e Regionais, n. 1, vol. 9, p. 25-39. A N P UR: $\mathrm{m}$ a i o, 2007 . D i s p o n ível e m: <http://www.anpur.org.br/revista/rbeur/index.php/rbeur/article/view/168>. Data 
de acesso: 17 de jul. 2013.

FERNANDES, M. E. (Coord.) et. Al. A cidade e seus limites: as contradições do urbano na "Califórnia Brasileira". São Paulo: Annablume; Fapesp; Ribeirão Preto; Unerp, 2004.

FERREIRA, J. S. W. Sistematização crítica da produção acadêmica, vol. 1, Departamento de Projeto da Faculdade de Arquitetura e Urbanismo da USP, FAU: janeiro, 2013.

FERREIRA, E.; ALVES, F. D. Organização espacial da cana-de-açúcar no estado de São Paulo. In: $V$ Encontro de grupos de pesquisa. Universidade Federal de Santa Maria, nov. 2009, Santa Maria, Anais... Santa Maria, 2009.

FERRO, F.; PEDROSO, M. T. Agronegócio x Agricultura Familiar: podemos fazer um debate menos maniqueísta? ANFFA Sindical: 2008. Disponível em: $<$ http://www.anffasindical.org.br/index.php?option=com_content\&view=article\&i d=492:artigo-agronegocio-x-agricultura-familiar-podemos-fazer-um-debatemenos-maniqueista\&catid=36\&ltemid=213> . Data de acesso 16 de jun. 2014.

FOLHA DE SÃO PAULO, Bombas e espancamentos na greve em Bebedouro. 17 de mai. 1984, p. 21.

FREDERICO, S. As cidades do agronegócio na fronteira agrícola moderna brasileira. Caderno Prudentino de Geografia, n.33, vol.1, p. 5-23. Associação dos Geógrafos Brasileiros - seção local Presidente Prudente. Presidente Prudente: ja n/jul. $2011 . \quad D i s p o n$ ível e m : <http://revista.fct.unesp.br/index.php/cpg/article/viewFile/1933/1813>. Data de acesso: 17 de jul. 2013.

GASPARETTO JÚNIOR, A. Proálcool. Infoescola. Disponível em: $<$ http://www.infoescola.com/combustiveis/proalcool/>. Data de acesso: 11 de jun. 2014.

GODIVA. Por que investir no mercado imobiliário de Ribeirão Preto? abr. 2011 . D i s p o n íve I e m : <http://consultoriaimobiliariariberao.blogspot.com.br/2011/04/por-que-investirno-mercado-imobiliario.html>. Data de acesso: 20 de mar. 2013.

GOTTDIENER, M. A reestruturação do espaço de assentamento. In: GOTTDIENER, M. A produção social do espaço urbano. 310 p. ed 2, São Paulo: Edusp, 1997.

GOMES, P. C. C. O conceito de região e sua discussão. In: CASTRO; CORREAA; GOMES, P. C. (Orgs.). Geografia - conceitos e temas. Rio de Janeiro: Bertrand Brasil, 2000. p. 49-77.

HALL, Peter. Cidades do Amanhã. São Paulo: Perspectiva, 1995.

HARVEY, D. O enigma do capital: e as crises do capitalismo. São Paulo: Boitempo, 2011. 
HASHIZUME, M. MPT pede cassação do selo de 'empresa compromissada' concedido a usinas sucroalcooleiras. Repórter Brasil, out./2012. Disponível em: <http://reporterbrasil.org.br/2012/10/mpt-pedecassacao-de-quot-selo-social-quot-concedido-a-usinas-pelo-planalto/>. Data de acesso 03 de jun. 2014.

INDÚSTRIAS SUCROALCOOLEIRAS se destacam na bolsa de valores. Valor Econ ô $\mathrm{m}$ i co , 02 d e ja n. 2013 . D i s pon ível e m : <http://www.novacana.com/n/industria/financeiro/industrias-sucroalcooleirasbolsa-valores-020113/> Data de acesso: 09 de maio de 2014.

JAMESON, F. O tijolo e o balão: arquitetura, idealismo e especulação imobiliária. In: A cultura do dinheiro: ensaios sobre a globalização. p. 173. Petrópolis: Vozes, 2001.

KARNOPP, E.; OLIVEIRA, V. S. Agronegócio e agricultura familiar: Reflexões sobre sistemas produtivos do espaço agrário brasileiro. REDES - Revista de Desenvolvimento Regional, v. 17, n. 2, p. 215 - 228, Santa Cruz do Sul: maio/ago, 2012.

KLAUSER, R. O Brasil na contramão da soberania alimentar. Instituto Humanitas Unísinos Online: out. 2013. Disponível em: < http://www.ihu.unisinos.br/entrevistas/inflacao-dos-alimentos-poe-em-risco-osobjetivos-do-milenio-entrevista-especial-com-raul-klauser/524742-inflacaod\%E2\%80\%A6> Data de acesso: 09 de maio de 2014.

KLINK, J. J. A cidade-região: Regionalismo e reestruturação no grande $A B C$ paulista. Rio de Janeiro: DP\&AEditora, 2001.

LEFEBVRE, H. A Revolução Urbana. Éditions Gallimard, 1970. Tradução: Ed. UFMG. Belo Horizonte: 1999.

O direito à cidade. São Paulo: Documentos, 1969.

LENCIONI, S. O processo de metropolização do Espaço. Uma nova maneira de falar da relação entre metropolização e regionalização. In: SCHIFFER, Sueli (Org.). Globalização e estrutura urbana, p. 153-165. São Paulo: Ed. HucitecFAPESP, 2004.

LIMA, E. S. Mais máquinas, mesma exploração. Brasil de fato. 13 de jun. 2011. Disponível em: <http://www.brasildefato.com.br/node/6578> Data de acesso: 09 de mai. 2014.

LOPES, M. O complexo agroindustrial canavieiro e a territorialização no estado de São Paulo. In: XVI Encontro Nacional dos Geógrafos. ISBN 978-8599907-02-3. Porto Alegre, 2010. Anais... Porto Alegre, 2010.

LOUIS DREYFUS COMMODITIES. [Apresentação da empresa]. Disponível em: <http://www.ldcommodities.com>. Data de acesso: 12 de dez. 2012.

MAIA, E. Nomes de seis construtoras que atuam em Juiz de Fora estão na lista suja do trabalho escravo. Acessa.com, 03 de jul. 2014. Cidades, notícias. Disponível em: <http://www.acessa.com/cidade/arquivo/noticias/2014/07/03- 
seis-construtoras-que-atuam-em-jf-estao-na-lista-do-trabalho-escravo/>. Data de acesso: 07 de ago. 2014.

MINISTÉRIO DA AGRICULTURA, PECUÁRIA E ABASTECIMENTO (Brasil). [Apresentação de políticas agrícolas]. Disponível em: <http://www.agricultura.gov.br/politica-agricola>. Acesso: 12 de jun. 2014.

. Agroindústria canavieira: ementário nacional - compêndio histórico de normativos e documentos legais [recurso eletrônico] / Ministério da Agricultura, Pecuária e Abastecimento. Secretaria de Produção e Agroenergia. 1 ed. Brasília : MAPA/ACS, 2009.

MINISTÉRIO DO DESENVOLVIMENTO AGRÁRIO (Brasil). Estatísticas do meio rural, ed. 4. Departamento Intersindical de Estatística e Estudos Socioeconômicos. Brasília: 2011.

MINISTÉRIO PÚBLICO DO TRABALHO (Brasil). Termo de ajuste de conduta $\mathbf{n}^{\circ}$ $2339 / 2011$. Portal Transparência. Disponível e m: $<$ http://mpt.gov.br/portaltransparencia/downloadtac.php?IDDOCUMENTO=7915 27>. Data de acesso: 06 de ago. 2014.

MINISTÉRIO DO TRABALHO E EMPREGO (Brasil). Portaria interministerial $\mathbf{n}^{\circ}$ 02 de 12 de maio de 2011. Cadastro de empregadores. Atualização semestral em $1^{\circ}$ de julho de 2014. Disponível em: <http://portal.mte.gov.br/portal-mte/>. Data de acesso: 06 de ago. 2014.

MONBEIG, Pierre. Pioneiros e fazendeiros de São Paulo. Tradução de Ary França e Raul de Andrade e Silva São Paulo: Ed. Hucitec-Polis, 1984.

NETTO, I. Fazendas S/A. Dinheiro rural, Caderno agronegócios, ed. 35, set. 2007 . D i s p o n í e I e m : <http://revistadinheirorural.terra.com.br/secao/agronegocios/fazendas-s-a>. Data de acesso 07 de ago. 2014.

NEVES, Karina. Relações cidade-campo: estudo da produção de conhecimento no âmbito da ciência geográfica a partir da consolidação do meio técnicocientífico-informacional no Brasil. XIX Encontro Nacional de Geografia Agrária, São Paulo, 2009, pp. 1-18. Anais... São Paulo, 2009.

NOGUEIRA, A. C. L. A Propriedade da Terra no Agronegócio. Portal do A gron e gó c i o, nov. 2011 . D i s p o n ível e m : $<$ www.portaldoagronegocio.com.br/conteudo.php?id=65713>. Data de acesso: 20 de mar. 2013.

NOVA CANA. Pro-Álcool - História da indústria sucroalcooleira. Disponível em: <http://www.biodieselbr.com/proalcool/historia/proalcool-industriasucroalcooeira.htm>. Data de acesso 11 de jun. 2014.

OLIVEIRA, A. U. Agricultura e indústria no Brasil. In: Campo-Território: revista de geografia agrária, v.5, n.10, p. 5-64, ago. 2010.

OLIVEIRA, F. [Sem título]. São Paulo: outubro, 2013. Entrevista concedida a Lívia 
Duarte e Joana Barros.

OTANI, M., YOSHII, R. Implicações socioeconômicas da mudança técnica no sistema de colheita de cana-de-açúcar, de cinco para sete ruas. Gabinete da Secretaria de Agricultura e Abastecimento. São Paulo: mar. 1983.

PAULANI, Leda. Brasil Delivery: Servidão financeira e estado de emergência econômico. São Paulo: Boitempo, 2008.

PDG. A companhia. Site da empresa. Disponível em: < http://www.pdg.com.br/>. Data de acesso 07 de ago. 2014.

PLANALSUCAR estimulou etanol no país. O Estado de São Paulo, Caderno de E c o nom i a. Nove m bro, 2010. D i s pon ível e m : $<$ http://economia.estadao.com.br/noticias/geral, planalsucar-estimulou-etanolno-pais-imp-,642600>. Data de acesso 12 de jun. 2014.

PECQUEUR, B. Le développement local. Ed. 2. Paris: Syros, 2000.

PIRES, E. L. S. Mutações econômicas e dinâmicas territoriais locais: delineamento preliminar dos aspectos conceituais e morfológicos. In: SOBARZO, O., SPÓSITO, E. S., SPOSITO, M. E. B (Orgs). Cidades Médias: produção do espaço urbano regional. ed. 1. São Paulo: Expressão Popular, 2006.

PROGRAMA DE MELHORAMENTO GENÉTICO DA CANA-DE-AÇÚCAR. Universidade Federal de São Carlos. [Sobre o programa]. Disponível em: <http://pmgca.dbv.cca.ufscar.br/>. Data de acesso: 11 de jun. 2014.

REIS, N. G. Notas sobre urbanização dispersa e novas formas de tecido urbano. São Paulo: LAP; FAPESP; Via das Artes, 2006.

Sobre dispersão urbana. Ed. 1. São Paulo: Via das Artes, 2009.

ROSS, Jurandyr (Org.). Geografia do Brasil. São Paulo: EdUSP, 1995.

SANTOS, Milton. A Natureza do Espaço: Técnica e Tempo, Razão e Emoção. São Paulo: EdUSP, 2006.

Técnica, espaço, tempo - globalização e meio técnico-científico informacional. São Paulo: Hucitec, 1984.

SANTOS JUNIOR, O. A. A Produção Capitalista do Espaço, os Conflitos Urbanos e o Direito à Cidade. In: SANTOS JÚNIOR, O. A. (Org.); CHSRITOVÃO, A. C.; NOVAES, P. R. Políticas Públicas e Direito à Cidade: Programa Interdisciplinar de Formação de Agentes Sociais e Conselheiros Municipais. Observatório das metrópoles - IPPUR/UFRJ. Rio de Janeiro: 2011. D i s p o n í ve I

e $\mathrm{m}$ :

http://observatoriodasmetropoles.net/download/miolo_livro_curso_baixada.pdf >. Data de acesso: 09 de dez. 2012.

SÃO PAULO (Estado). Fundação Sistema Estadual de Análise de Dados. PIB dos municípios paulistas 2000-2010. São Paulo, 2012.

. Fundação Sistema Estadual de Análise de Dados. Região 
Administrativa de Ribeirão Preto. 2004. Disponível em: <http://www.seade.gov.br/produtos/iprs/analises/RARibPreto.pdf>. Data de acesso: 10 de fev. 2012.

. Fundação Sistema Estadual de Análise de Dados. Região Administrativa de Ribeirão Preto. FOCO: Diagnóstico para Ações Regionais da Secretaria do Emprego e Relações do Trabalho do Estado de São Paulo. São $\mathrm{P}$ a u I o, $2010 . \quad \mathrm{D}$ i s p o n í v e l e m : <http://www.seade.gov.br/projetos/simtrabalho/foco/RA_RibeiraoPreto.pdf>. Data de acesso 10 de fev. 2012.

. Instituto Geográfico e Cartográfico. Mapas. Disponível em: <http://www.igc.sp.gov.br/produtos/mapas_ra.aspx?>. Data de acesso: set. 2013.

. Secretaria de Energia. [Mapas, tabelas e Informações sobre usinas e destilarias no Estado de São Paulo]. Disponível em: http://www.energia.sp.gov.br/portal.php/mapas_biomassa>. Data de acesso: 13 de set. 2013.

Secretaria de Planejamento e Desenvolvimento Regional. Caracterização socioeconômica de São Paulo: região administrativa de Ribeirão Preto. Fevereiro, 2012 . Disponível em: <http://www.planejamento.sp.gov.br/noti_anexo/files/uam/trabalhos/Ribeir\%C3 \%A30\%20Preto.pdf>. Data de acesso: 20 de mar. 2013.

SAQUET, D. B.; SAQUET, M. A. Parques industriais, fluxos e redefinições do espaço urbano. In: SOBARZO, O., SPÓSITO, E. S., SPOSITO, M. E. B (Orgs). Cidades Médias: produção do espaço urbano regional. ed. 1. São Paulo: Expressão Popular, 2006.

SAUER, S. Esse ufanismo de que o Brasil é o celeiro do mundo é uma falácia: entrevista. [Juazeiro: 19 de mai. 2014] Revista Fórum. Entrevista concedida a Anna Beatriz Anjos durante III Encontro Nacional de Agroecologia. Disponível em: <http://www.revistaforum.com.br/digital/148/esse-ufanismo-de-que-o-brasile-o-celeiro-mundo-e-uma-falacia/>. Data de acesso: 23 de julho de 2014.

SCARAMUZZO, M. Tradicionais usineiros viram minoritários. O Estado de $S$. $P$ a u lo, 03 d e fev. 2014 . D i s pon ível e m: <http://www.novacana.com/n/industria/usinas/tradicionais-usineirosminoritarios-030214/> Data de acesso: 11 de jun. 2014.

SHIVA, V. Agronegócio, um modelo esgotado. In: III Encontro Internacional de Agroecologia, Botucatu: jul/ago. 2013. Registro elaborado por Péricles de Oliveira. Disponível em: < www.agroecologia.org.br/index.php/noticias/noticiaspara-o-boletim/513-agronegocio-um-modelo-esgotado> Data de acesso: 24 de julho de 2014.

SILVA, M. A. M. Mortes e acidentes nas profundezas do 'mar de cana' e dos laranjais paulistas. In: INTERFACEHS, Revista de Gestão Integrada em Saúde do Trabalho e Meio Ambiente, v.3, n.2, Artigo 1, abr./ago. 2008. 
Reestruturação produtiva e os impactos sobre os migrantes. In: CONSEJO LATIONAMERICANO DE CIENCIAS SOCIALES. Una nueva ruralidad en América Latina? Buenos Aires, 2001, p. 289-305.

SILVA, M. A. M., MARTINS, R. C. A degradação social do trabalho e da natureza no contexto da monocultura canavieira paulista. Revista Sociologias, ano 12, n. 24, Porto Alegre: mai/ago. 2010. p. 196-240.

SINGER, P. De dependência em dependência: consentida, tolerada e desejada, Estudos Avançados, v. 12, n. 33, São Paulo: maio/ago. 1998, p. 119-30.

. Economia Política da urbanização. Ed. Brasiliense. São Paulo: 1973.

O uso do solo urbano na economia capitalista. In: MARICATO, E. (org). A produção capitalista da casa e da cidade. São Paulo: Alfa Omega, 1979.

SOBARZO, O.; SPÓSITO, E. S.; SPOSITO, M. E. B (Orgs). Cidades Médias: produção do espaço urbano regional. ed. 1. São Paulo: Expressão Popular, 2006.

SOJA, E. The New Regionalism: A conversation with Edward Soja. Summer, 2002. University of California, Los Angeles: Critical Planning. Entrevista concedida a Renia Ehrenfeucht.

SOUZA, M. L. Introdução: a "nova geração" de movimentos sociais urbanos - e a nova onda de interesse acadêmico pelo assunto. Cidades, Presidente Prudente, v. 6, n. 9, p. 9-26, jan./jun., 2009.

UNIÃO DA INDÚSTRIA DE CANA-DE-AÇÚCAR. Disponível em: < http://www.unica.com.br/>. Data de acesso: 05 de out. 2014.

VERAS, D. Convenções e acordos coletivos. Florianópolis: jan. 2007. Disponível em: <https://sites.google.com/site/dauroveras/convencoes_cana>. Data de acesso 04/06/2014.

VIAN, C. E. F. Agroindústria canavieira: estratégias competitivas e modernização. São Paulo: Átomo, 2003.

VILLA, S. B. O mercado imobiliário em Ribeirão Preto: produção de apartamentos no início do século $21 \mathrm{sob}$ a ótica paulistana. In: VIII Seminário Internacional da LARES, Mercados emergentes de Real Estate: novos desafios e oportunidades. São Paulo: setembro, 2008. Disponível em: <http://www.lares.org.br/2008/img/Artigo045-Villa.pdf>. Data de acesso: 20/03/2013.

VILLAÇA, F. A delimitação territorial no processo urbano. FAU-USP. São Paulo, 1997. Disponível em: http://www.flaviovillaca.arq.br/pdf/intra497.pdf

A segregação e a estruturação do espaço intra-urbano: o caso de Recife. II Seminário da Rede de Dinâmica Imobiliária e Estruturação Intra-urbana. ANPUR e NEUR/ UnB, Pirenópolis, 1996. Disponível em: www.flaviovillaca.arq.br/pdf/pirnp896.pdf 
As ilusões do plano diretor. São Paulo, 2005. Disponível em http://www.flaviovillaca.arq.br/livros01.html

Espaço intra-urbano no Brasil. São Paulo: Studio Nobel: FAPESP: Lincoln Institute, 1998.

O que todo cidadão precisa saber sobre habitação. São Paulo:

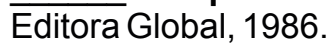

Perspectivas do planejamento urbano no Brasil hoje. Campo Grande: 2000.

VOLOCHKO, D. Novos espaços e cotidiano desigual nas periferias da metrópole. Tese de Doutorado. Faculdade de Filosofia, Letras e Ciências Humanas, Universidade de São Paulo. São Paulo: 2011. 



Este trabalho busca analisar a relação entre o agronegócio e a produção e reprodução do espaço urbano, tendo como foco a região de Ribeirão Preto - SP, dada sua importância econômica na produção agrícola sucroalcooleira nacional, apontando os processos de mecanização, industrialização e reestruturações produtivas no território regional, por meio da implantação de complexos agroindustriais, a partir dos anos 1970, sendo abordadas as noções de região e território, para caracterização do objeto de pesquisa, e destacada a atuação direta do Estado na produção sucroalcooleira e na expansão urbana nacional. Serão apontadas as alterações produtivas no contexto neoliberal a partir dos anos 1980 , assim como o papel do setor privado e os processos de fusão, aquisição e transnacionalização no setor sucroalcooleiro. A relação cidade-campo será discutida, considerando a produção agrícola enquanto esfera produtiva de grande relevância para o desenvolvimento das cidades da região, apontando os conflitos do agronegócio e seus desdobramentos no âmbito urbano. A abordagem da expansão do mercado financeiro à produção agrícola de commodities e ao mercado imobiliário, por fim, aproximará o agronegócio e a reprodução do urbano, culminando na questão da terra enquanto denominador comum entre mercados financeirizados.

Palavras-chave: agronegócio, reprodução do espaço urbano, financeirização, reestruturações produtivas, territorialidade. 